\title{
Animal remains from Neolithic Lameiras, Sintra: the earliest domesticated sheep, goat, cattle and pigs in Portugal and some notes on their evolution
}

\author{
SIMON J.M. DAVIS ${ }^{1}$, SÓNIA GABRIEL ${ }^{1} \&$ TERESA SIMÕES ${ }^{2}$ \\ ${ }^{1}$ Laboratório de Arqueociências (LARC), DGPC, Calçada do Mirante à Ajuda 10A, 1300-087 Lisboa \\ and: UNIARQ - Centro de Arqueologia da Universidade de Lisboa \\ Faculdade de Letras da Universidade de Lisboa and: Centro de Investigação em Biodiversidade \\ Universidade do Porto \\ Campus Agrário de Vairão \\ ${ }^{2}$ Museu Arqueológico de São Miguel de Odrinhas, Avenida Prof. Fernando de Almeida, \\ São Miguel de Odrinhas, 2705-739 São João das Lampas, Sintra \\ [TS directed the excavations, SG studied the fish and SJMD studied the mammals]
}

(Received 19 January 2017; Revised 5 June 2017; Accepted 23 December 2017)

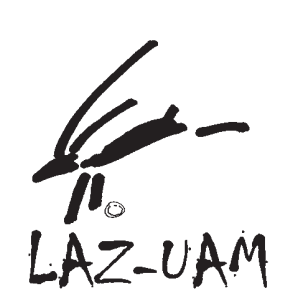

ABSTRACT: The fauna of Neolithic Lameiras includes abundant sheep. Many could be securely identified by applying criteria described by the late Joachim Boessneck as well as metrical methods. Sheep bones from Early Neolithic contexts, several dated directly via ${ }^{14} \mathrm{C}$, pinpoint the arrival here, $5450 \mathrm{cal} \mathrm{BC}$, of this exotic animal three thousand years after its domestication 5000 $\mathrm{km}$ to the east. Thus sheep were transported at a rate of $1,6 \mathrm{~km}$ per year - considerably faster than suggested by the 'wave of advance' theory. It therefore seems probable that part of the journey was undertaken by ship. Most of the mammal remains identified at Lameiras belonged to domesticated forms and besides sheep and some goat, they include cattle and pig. Zooarchaeologically there is little difference between Early and Late Neolithic. However the Neolithic spectrum of species contrasts with that from a small assemblage in the underlying Mousterian level as well as other pre-Neolithic assemblages in Portugal. It is possible that in southern Portugal the adoption of animal husbandry was sudden. Measurements of the remains of Canis, Bos, Ovis, Capra and Sus compared with an increasingly large corpus of data from the South-Western part of the Iberian Peninsula indicate several occasions when these animals underwent size changes. Bos, Capra and Canis were considerably larger in the Pleistocene - a size difference now documented in other regions. Besides a Pleistocene-Holocene reduction in size, they underwent a further diminution associated with their domestication. It is possible that aurochs and wild boar recovered some of their former size after the Neolithic, perhaps due to a relaxation of hunting pressure after the Mesolithic. Domestic sheep, goats and cattle increased in size in more recent times perhaps reflecting Moslem and Christian improvements.

\section{KEYWORDS: FAUNA, DOMESTICATES, NEOLITHIC, PORTUGAL, EVOLUTION}

RESUMEN: La fauna neolítica de Lameiras incluye numerosas ovejas. Muchas pudieron ser identificadas al aplicar los criterios descritos por el fallecido J. Boessneck y por métodos métricos. Los huesos de oveja de los contextos del Neolítico temprano, algunos datados a través del $\mathrm{C}^{14}$, apuntan a la llegada de esta especie hacia el 5.450 cal. D.C. 3.000 años después de su domesticación a $5.000 \mathrm{~km}$ de distancia hacia el Oriente. De este modo, las ovejas fueron transportadas a un ritmo de $1,6 \mathrm{~km}$ al año lo cual es considerablemente más rápido que lo sugerido por la llamada teoría de la "ola de avance". Por ello, parece probable que parte de este viaje se haya llevado a cabo en barco. La mayoría de los restos de mamíferos identificados en Lameiras representan formas domésticas que además de la oveja y alguna cabra incorporan vacuno y porcino. Desde un punto de vista zooarqueológico existe poca diferencia entre el Neolítico temprano y tardío. Sin 
embargo, el espectro de especies neolíticas contrasta con el de una pequeña muestra en el nivel musteriense que subyace a estos depósitos así como a otras muestras preneoliticas en Portugal. Es posible que en el sur de Portugal la adopción de la práctica ganadera haya sido rápida. Los valores de los restos de Canis, Bos, Ovis, Capra y Sus apuntan a varios momentos en los cuales los animales sufrieron cambios de tamaño, datos que encajan con el corpus osteométrico que se viene recopilando para el sector sudoccidental de la Península Ibérica. Bos, Capra y Canis eran considerablemente más grandes en el Pleistoceno, una diferencia de talla ahora documentada en otras regiones. Además de la reducción de tamaño durante la transición Pleistoceno-Holoceno estas especies sufrieron otra adicional asociada con su proceso de domesticación. Es posible que tanto uros como jabalíes recuperasen parte de sus antiguas tallas al concluir el Neolítico. Quizás ello se deba a una relajación en la presión de caza operada tras el Mesolítico. Las ovejas, cabras y vacas domésticas aumentaron de tamaño en épocas más recientes reflejando posiblemente mejoras en las prácticas pecuarias de musulmanes y cristianos.

PALABRAS CLAVE: FAUNA, ANIMALES DOMÉSTICOS, NEOLÍTICO, PORTUGAL, EVOLUCIÓN

Ever since man assumed the habit, at least 10,000 years ago, of living in more or less permanent settlements, his relationship to the animal world has undergone changes. As a hunter and food collector he felt essentially a part of nature, but once permanent settlement had become the rule, his attitude to animals was profoundly changed. The outcome of this process was the domestication of certain species, with most of which we are familiar at the present day. (Frederick E. Zeuner, 1963 A History of Domesticated Animals, p. 9)

“... this dim beginning of the Neolithic period, ... a time when the world was gathering its forces... wise men came out of the East, ... in the New Stone Age, were to press along to the cry of "Westward Ho," and build up new civilizations. ... They had domesticated the dog, and it may have occurred to them to do the same with other animals, and so save themselves the trouble of hunting. ... man became a herdsman, and had flocks to tend. This added to his responsibilities; while as hunter, or beach-comber, his cares were few, he must have found that with possessions his troubles began." (Marjorie \& Charles H.B. Quennell, 1922 Everyday life in the New Stone, Bronze \& Early Iron Ages, p. 3.)

The Sheep is certainly one of the animals which was first placed by the Divine Providence under subjection to man. From the earliest period of the world's history it has continued administering to the want of almost all nations, and at the present time, is more extensively used in the human economy than any other animal.

(Sir William Jardine, 1836 The Naturalist's Library; XXII Mammalia. Ruminantia, p. 128)

\section{INTRODUCTION}

Seven kilometres North East of the town of Sintra (Estremadura), $143 \mathrm{~m}$ above sea level and some $10 \mathrm{~km}$ inland as a crow might fly from the present-day coast of the Lisbon Peninsula; lay the ancient settlement of Lapiás das Lameiras. It is at latitude $38^{\circ} 50$ ' $47,5 \mathrm{~N}$ and longitude $9^{\circ} 20^{\prime} 36,7 \mathrm{~W}$ (Figure 1). $230 \mathrm{~m}^{2}$ of this archaeological site were extensively excavated under the direction of one of us, TS, in 2002 and TS, Patrícia Jordão and Pedro Mendes in 2003, 2004 and 2005 (Mendes et al., 2005; Simões, 2004) prior to its destruction to make way for a modern housing estate. Some
Mousterian and much Early Neolithic (EN; including Evolved Early Neolithic, EEN) and Late Neolithic (LN) as well as some Chalcolithic remains were uncovered at Lameiras.

Herein we describe the animal remains that were uncovered from this settlement. Lameiras is the first Neolithic excavation in Portugal that has provided a substantial quantity of bones which includes, as we shall describe, many sheep - some of which were directly ${ }^{14} \mathrm{C}$ dated. One of our main aims is to show that we have correctly identified the presence of sheep (Ovis) in the Early Neolithic. Domesticated sheep, like domesticated cereals, cattle, goats and pigs, are part of the so- 
called 'Neolithic Package' signifying the practise of animal and plant husbandry or farming. This is because there were no sheep in Europe prior to their domestication. Wild sheep lived, and still live, some 4-5000 km away to the east where they were first domesticated in the mid $9^{\text {th }}$ millennium BC - probably in the Upper Euphrates-Tigris basin (Peters et al., 2005). Genetic studies, both of the numbers of chromosomes (karyotype) and DNA structure, indicate that of the four species of wild sheep distributed across Asia and into the Near East, the ancestor of our domesticated sheep was the west Asian mouflon, Ovis orientalis (Nadler et al., 1973; Bunch et al., 1976; Hiendleder et al., 2002; Pedrosa et al., 2005; Chessa et al., 2009).

With direct ${ }^{14} \mathrm{C}$ dates obtained from several of the Lameiras sheep bones, we can be fairly sure that animal husbandry began here in southern Portugal in the sixth millennium BC. Moreover, we can now estimate how long it took for this animal to be shepherded out of the Near East and across Europe to Portugal. However, sheep bones are easily confused with bones of other taxa especially Capra that are common on archaeological sites. In their discussion of the evidence for early farming economies in the Iberian Peninsula, Zilhão (2011) and Martins et al. (2015) emphasize the importance not only of secure dates of Early Neolithic sheep bones but also their correct identification with supporting descriptions - both graphical and metrical. We try to provide full supporting evidence - morphological and metrical - for our identifications. Besides the sheep remains, the Lameiras faunal collection is of great importance.

Considered within an ever expanding knowledge of faunal remains from late Pleistocene and Chalcolithic to post-Medieval archaeological sites, the Neolithic bones from Lameiras fill an important gap in the history of the fauna of Portugal during the last 30 millennia. Hence we now have a chronologically extended and more complete sequence which can help us understand the evolution of the more common animals that comprise the Portuguese fauna. Moreover, given the good preservation of many of the Lameiras bones, their measurements - in particular those of Bos, Ovis, Capra and Sus - contribute towards a long-term study of the osteometric variation of these animals. With this important gap in the zooarchaeological succession partly filled (if in only a small way), we interpret variations in terms of environmental conditions, hunting pressure, domestic status and subsequent improvement.

A small, but nonetheless significant, collection of fish bones from both Early and Late Neolithic levels was also recovered. Most of the fish bones are from the Early Neolithic. These aid our understanding of fish procurement and utilization in the past. Despite their small number the fish are of particular interest as, like mammals, few fishbone collections are known from Neolithic Portugal.

We discuss certain questions concerning both the Neolithic of Portugal and the evolution of the main taxa represented at Lameiras. For example did the Neolithic with its exotic fauna (e.g., domestic sheep) appear suddenly in the zooarchaeological record? Did the inhabitants of Lameiras continue the hunting, fishing and gathering lifestyle of their Palaeolithic and Mesolithic forebears? Was animal husbandry at Lameiras different from that practised in later times, and if so, when did changes occur?

\section{MATERIAL AND METHODS}

The Lameiras animal bones were recovered by hand and most are well preserved. One important caveat relates to the method of excavation. Many of the Early Neolithic contexts and only a few of the Late Neolithic ones were subjected to careful wet sieving. No quantitative account of the proportions of sieved and unsieved materials was made at the time of the excavation. This, at least in part, explains the greater proportion of fish and certain small animals represented in the EN compared to the LN. Some 1000 remains of medium and large-sized mammals, over 100 rabbits, a few birds, amphibia, reptiles and 80 fish bones were identified and recorded. This collection is therefore sufficiently large to indicate approximately the percentages of the more common animals, and, for the more abundant taxa, to provide some useful measurements (the raw measurements, in tenths of a millimetre, of teeth and bones are given in Appendix A) and a rough estimate of their ages when slaughtered (dental eruption and wear stages are given in Appendix B). The 80 fish bones are described separately below.

For a full description of the methods used to record and count the mammal bones see Davis (1992, 
2002). In brief, mandibular teeth and a restricted suite of Parts of the Skeleton Always Counted or PoSACs (i.e., a predetermined set of articular ends/ epiphyses and metaphyses of girdle, limb and foot bones) were recorded. In order to avoid multiple counting of very fragmented bones, at least $50 \%$ of a given part had to be present for it to be included in the records.

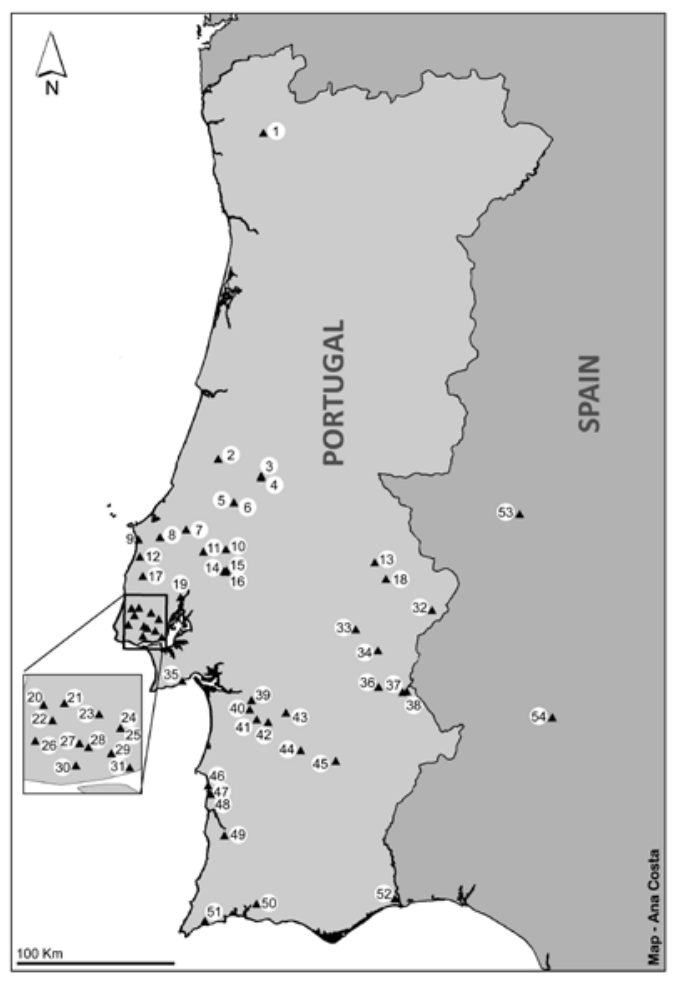

FIGURE 1

Map of the south western part of the Iberian Peninsula to show the locations of sites mentioned. 1 - Rendufe (Mosteiro de Sto. André); 2 - Lagar Velho; 3 - Cadaval; 4 - Caldeirão; 5 - Lapa dos Coelhos; 6 - Gruta da Oliveira; 7 - Abrigo Grande das Bocas (Abrigo I das Bocas); 8 - Castro Columbeira; 9 - Vale de Frade; 10 - Alcáçova de Santarém; 11 - Vila Nova São Pedro; 12 - Toledo; 13 - São Pedro Fronteira; 14 - Cabeço da Arruda; 15 - Cabeço da Amoreira; 16 - Moita do Sebastião; 17 - Castro do Zambujal; 18 - Torre de Palma; 19 - Vila Franca Xira; 20 - São Miguel, Odrinhas; 21 - Penedo Lexim; 22 - Lapiás de LAMEIRAS; 23 Pego do Diabo; 24 - Almoinhas-Villa; 25 - Almoinhas-Habitat; 26 - São Pedro Canaferrim; 27 - Belas; 28 - Espargueira-Serra das Éguas; 29 - Carnide (Largo do Coreto); 30 - Leceia; 31 Palácio Centeno; 32 - Paraíso (Horta do); 33 - Evoramonte; 34 - São Pedro, Redondo; 35 - Figueira Brava; 36 - Perdigões; 37 - Mercador; 38 - Barca do Xerez; 39 - Barrosinha; 40 - Arapouco; 41 - Poças de São Bento; 42 - Cabeço das Amoreiras; 43 - Monte da Tumba; 44 - Porto Torrão; 45 - Beja (Av. Miguel Fernandes); 46 - Samouqueira-I; 47 - Vidigal-Abrigo; 48 - Vidigal-Concheiro; 49 - Fiais; 50 - Silves (Biblioteca, Rua Cruz de Portugal); 51 - Vale Boi; 52 - Castro Marim; 53 - Los Barruecos; 54 - Los Castillejos.
The epiphysis of a mammal-bone is described as either "unfused" or "fused"; "unfused" when there are no spicules of bone connecting epiphysis to shaft so that the two separate easily, and "fused" when the epiphysis cannot be detached from the metaphysis. Caprine teeth were assigned to the eruption and wear stages of Payne $(1973,1987)$. Cattle and pig teeth were assigned to the eruption and wear stages of Grant (1982). Measurements taken on the humerus and metapodials are illustrated in figure 1 in Davis (1996). In general, other measurements taken are those recommended by Driesch (1976). Some of these are used to determine the status - wild or domestic - of the animal species in question and others are used to aid in the distinction between taxa as is illustrated in the figures herein. Measurements are also a useful aid in understanding the variation of animal size in the course of time - variations that can be associated with environmental and cultural factors.

The fish assemblage comprises 80 specimens of which 73 could be identified to species or higher taxonomic level as in Whitehead et al. (1989). Fish remains were quantified using the Numbers of Identified Specimens (NISP) - the raw bone counts for each taxon. Minimum Numbers of Individuals (MNI) were also estimated using paired elements and vertebrae when their features permitted assignment to species and/or location within the vertebral column. Measurements were taken according to Morales \& Rosenlund (1979). The approximate sizes of the Lameiras fish were estimated by comparing them to specimens of known length in the LARC reference collection. Size estimates refer to the total length of fish (TL) - measured from the tip of the snout to the edge of the tail. Natural and cultural alterations were also recorded in order to recognise which agents were responsible for the accumulation of the fish bones.

The animal remains from Lameiras are stored in the Archaeology Museum of São Miguel de Odrinhas, near Sintra.

\section{DATES}

Four distal humeri and a distal metacarpal identified as sheep contained sufficient organic matter to enable radiocarbon dating by the Oxford Radiocarbon Laboratory. Their dates are as follows: 


$\begin{array}{llllll}\text { Humerus-distal } & \text { UE 71 } & \text { (Late Neolithic) } & \text { OxA-29112 } & 4122 \pm 33 \mathrm{BP} & =2869-2579 \mathrm{cal} \mathrm{BC} \\ \text { Humerus-distal } & \text { UE 53 } & \text { (Early Neolithic) } & \text { OxA-29234 } & 6186 \pm 36 \mathrm{BP} & =5286-5019 \mathrm{cal} \mathrm{BC} \\ \text { Humerus-distal } & \text { UE 27-2 } & \text { (Early Neolithic) } & \text { OxA-29111 } & 6314 \pm 33 \mathrm{BP} & =5357-5220 \mathrm{cal} \mathrm{BC} \\ \begin{array}{l}\text { Metacarpal-distal } \\ \text { He 53 }\end{array} & \text { (Early Neolithic) } & \text { OxA-29110 } & 6494 \pm 34 \mathrm{BP} & =5517-5374 \mathrm{cal} \mathrm{BC} \\ \text { Humerus-distal } & \text { UE 53 } & \text { (Early Neolithic) } & \text { OxA-29109 } & 6497 \pm 34 \mathrm{BP} & =5521-5375 \mathrm{cal} \mathrm{BC}\end{array}$

The two oldest dates obtained from these Lameiras sheep bones, like the two from the Early Neolithic at Caldeirão cave, can be calibrated to approximately $5,450 \mathrm{cal} \mathrm{BC}$. This is the beginning of the Early Neolithic in Portugal which is generally considered to date from a little before approximately $5,400 \mathrm{cal}$ BC (Zilhão, 2001; Carvalho, 2003 and pers. com.; Bernabeu et al., 2014). The Early Neolithic has similar dates in Catalonia (Cebrià et al., 2014; Martins et al., 2015). Martins et al., (2015) even argue that the date of arrival of the Early Neolithic in Catalonia is "statistically indistinguishable" from its arrival in Portugal which supports Zilhão's (2001) maritime colonization hypothesis, but is delayed by many centuries in NW Portugal, Galicia and Cantabria (see also below). In order to avoid problems associated with stratigraphic contamination and factors like the 'old wood' problem, these investigators restricted their considerations to radiocarbon dates obtained from charred seeds of wheat and barley and confirmed sheep bones from Catalonia.

\section{A DESCRIPTION OF TAXA IDENTIFIED AND THE SIZE AND SHAPE OF THEIR BONES}

The mammal remains from Neolithic Lameiras include, among others, the following taxa (Tables 1-7): caprines (most sheep and some goats), Sus (probably most if not all pig; the two being difficult to distinguish), Bos (most, if not all, cattle but there may be some aurochs bones), and Capreolus (roe deer). Of the few bones from the Mousterian, most are horse, an animal also present in the Chalcolithic along with a bone that clearly belonged to a much smaller equid. Altogether these remains provide a substantial corpus of measurements that, when set out graphically alongside their late Pleistocene - modern relatives in Portugal, provide a more complete picture of how they changed size in the course of time. It is possible in certain cases to associate size variations with changes in the environment or the direct or indirect influence of man. Since measurements have played an important role in our identification of the animal remains from
Lameiras and their evolution, let us briefly consider some of the factors that can influence body size - a most important biological variable for the zooarchaeologist.

In this section we try to explain how we have made our identifications at Lameiras. These rely to a large extent on comparing size and shape between closely related taxa to aid in their separation, and also between samples of the same taxon in order to distinguish between their wild and domestic forms. Wild ungulates are, for example, considerably larger than their domestic cousins. In brief, mammal size can be influenced by environmental temperature, overhunting, wild-domestic status and artificial selection (i.e., improvement).

Many mammals are known to have undergone a size change at the Pleistocene - Holocene boundary in many different parts of the world. Examples include North America (Harris \& Mundel, 1974; Schultz, 1976); South Africa (Hendey, 1974; Klein, 1976); Sumatra (Badoux, 1964); Spain (Castaños, 1987, 1990) and the Near East (Kurtén, 1965; Tchernov, 1968; Clutton-Brock, 1969; Davis, 1981). The red deer, goats, aurochs (wild cattle), rabbits and wolves of late Pleistocene Portugal were also considerably larger than in the early Holocene (see below and also Davis \& Moreno-García, 2007; Davis \& Mataloto, 2012; Davis \& Detry, 2013). This Pleistocene - Holocene size reduction of many mammalian taxa may be associated with the drastic climate changes that occurred some 11-12 thousand years ago. Generally, those taxa that in the past underwent a size decrease at the end of the Ice Age, today become smaller as environmental temperature increases. For example wolves were large in the late Pleistocene and today wolves decrease in size from Russia/Scandinavia to Arabia (Davis, 1981). In modern humans too, Ruff (1994) notes an inverse correlation between body size and environmental temperature.

The domestication of animals was accompanied by size changes - rabbits and chickens became larger and cattle, sheep, goat and pigs became smaller - changes discussed by Charles Darwin (1885; vol 1). Most dogs are smaller than their ancestor the wolf. Size is therefore one of the most useful cri- 


\begin{tabular}{|c|c|c|c|c|c|c|c|c|c|c|c|c|c|c|}
\hline Bone/tooth & $\mathrm{F} / \mathrm{U}$ & Bos & Ovis/Capra & (Capra) & (Ovis) & Sus & CEE & CAC & Equus & Lepus & ORC & Canis & Vulpes & Felis \\
\hline $\mathrm{dP}_{4}$ & & - & & & & - & - & - & - & & & - & - & - \\
\hline $\mathrm{P}_{4}$ & & - & - & & & - & - & - & - & & & - & - & - \\
\hline $\mathrm{P}_{3 / 4}$ & & - & - & & & - & - & - & 2 & & & & & \\
\hline $\mathrm{M}_{1}$ & & - & - & & & - & - & - & - & & & - & - & - \\
\hline $\mathrm{M}_{1 / 2}$ & & 1 & - & & & - & 1 & - & 3 & & & & & \\
\hline $\mathrm{M}_{2}$ & & - & - & & & - & - & - & 1 & & & - & - & \\
\hline $\mathrm{M}_{3}$ & & 1 & - & & & - & - & - & 4 & & & & & \\
\hline Mandible & & & & & & & & & & - & - & & & \\
\hline Scapula & $\mathrm{U}$ & - & - & & & - & - & - & - & - & - & - & - & - \\
\hline " & $\mathrm{F}$ & - & - & & & - & - & - & - & - & - & - & - & - \\
\hline$"$ & $?$ & - & - & & & - & - & - & - & - & - & - & - & - \\
\hline Humerus & $\mathrm{UM}$ & - & - & & & - & - & - & - & - & - & - & - & - \\
\hline “ & UE & - & - & & & - & - & - & - & - & - & - & - & - \\
\hline " & $\mathrm{F}$ & - & - & & & - & $1(? \mathrm{~F})$ & - & - & - & 2 & - & - & - \\
\hline Radius & $\mathrm{UM}$ & - & - & & & - & - & - & - & - & - & - & - & - \\
\hline$"$ & UE & - & - & & & - & - & - & - & - & - & - & - & - \\
\hline “" & $\mathrm{F}$ & - & - & & & - & - & - & - & - & - & - & - & - \\
\hline Metacarpal & $\mathrm{UM}$ & - & - & & & - & - & - & - & - & - & - & - & - \\
\hline “ & UE & - & - & & & - & - & - & - & - & - & - & - & - \\
\hline “" & $\mathrm{F}$ & - & - & & & - & - & - & - & - & - & - & - & - \\
\hline Ischium & & - & - & & & - & - & - & - & - & - & - & - & - \\
\hline Femur & $\mathrm{UM}$ & - & - & & & - & - & - & - & - & - & - & - & - \\
\hline " & UE & - & - & & & - & - & - & - & - & - & - & - & - \\
\hline “" & $\mathrm{F}$ & - & - & & & - & - & - & - & - & - & - & - & - \\
\hline Tibia & $\mathrm{UM}$ & - & - & & & - & - & - & - & - & - & - & - & - \\
\hline “" & UE & - & - & & & - & - & - & - & - & - & - & - & - \\
\hline “" & $\mathrm{F}$ & - & - & & & - & - & - & - & - & 1 & - & - & - \\
\hline Calcaneum & $\mathrm{U}$ & - & 1 & & & - & - & - & - & - & - & - & - & - \\
\hline “" & $\mathrm{F}$ & - & - & & & - & - & - & - & - & 8 & - & - & - \\
\hline “ & $?$ & - & - & & & - & - & - & - & 1 & 1 & - & - & - \\
\hline Astragalus & & - & - & & & - & - & - & - & - & 3 & - & - & - \\
\hline Metatarsal & $\mathrm{UM}$ & - & - & & & - & - & - & - & - & - & - & - & - \\
\hline " & UE & - & - & & & - & - & - & - & - & - & - & - & - \\
\hline “" & $\mathrm{F}$ & - & - & & & - & - & - & - & - & - & - & - & - \\
\hline Phalanx I & $\mathrm{UM}$ & - & - & & & - & - & - & - & - & - & - & - & - \\
\hline “" & UE & - & - & & & - & - & - & - & - & - & - & - & - \\
\hline “ & $\mathrm{F}$ & - & - & & & - & - & - & - & - & - & - & - & - \\
\hline Phalanx III & & - & - & & & - & - & - & - & - & - & - & - & - \\
\hline Metapodial & UM & - & - & & & - & - & - & - & - & - & - & - & - \\
\hline “ & UE & - & - & & & - & - & - & - & - & - & - & - & - \\
\hline “" & $\mathrm{F}$ & - & - & & & - & - & - & - & - & - & - & - & - \\
\hline Others & & $\begin{array}{c}1 \text { molar } \\
\text { frag }\end{array}$ & & & & & & & $\begin{array}{c}1 \mathrm{M} \& \\
3 \mathrm{PM} / \mathrm{M}\end{array}$ & & & & & \\
\hline
\end{tabular}

TABLE 1

Lameiras Mousterian - counts of mammalian bones.

teria for zooarchaeologists to use when trying to identify the status - wild or domestic - of the animals represented in an archaeological assemblage (Reed, 1961; Higham, 1968; Uerpmann, 1979).

Continued and excessive hunting of mammals may lead to diminution of size (Koch \& Barnosky,
2006); as Miłkowski \& Wójcik (1984) and Coltman et al., (2003) noted in Polish wild boars and Canadian wild sheep respectively.

In later (historical) times, size variations in lineages of domestic livestock can be discerned by the zooarchaeologist. Size increases are presumed 


\begin{tabular}{|c|c|c|c|c|c|c|c|c|c|c|c|c|c|c|}
\hline Bone/tooth & $\mathrm{F} / \mathrm{U}$ & Bos & Ovis/Capra & (Capra) & (Ovis) & Sus & CEE & CAC & Equus & Lepus & ORC & Canis & Vulpes & Felis \\
\hline $\mathrm{dP}_{4}$ & & 1 & 11 & (1) & (9) & 4 & - & - & - & & & - & - & - \\
\hline $\mathrm{P}_{4}$ & & - & 6 & & & 3 & - & - & - & & & - & - & - \\
\hline $\mathrm{P}_{3 / 4}$ & & - & - & & & - & - & - & - & & & - & - & - \\
\hline $\mathrm{M}_{1}$ & & - & 8 & (1) & (4) & 1 & - & - & - & & & - & - & - \\
\hline $\mathrm{M}_{1 / 2}$ & & 1 & 11 & & & 8 & - & - & - & & & - & - & - \\
\hline $\mathrm{M}_{2}$ & & - & 3 & & (3) & 2 & - & - & - & & & - & - & \\
\hline $\mathrm{M}_{3}$ & & - & 5 & & & 3 & - & - & - & & & & & \\
\hline Mandible & & & & & & & & & - & - & 1 & & & \\
\hline Scapula & $\mathrm{U}$ & - & 1 & & & 1 & - & - & - & - & - & - & - & - \\
\hline “" & $\mathrm{F}$ & 1 & 2 & & & 2 & - & - & - & - & 3 & - & - & 1 \\
\hline " & $?$ & - & 2 & & & - & - & - & - & - & - & - & - & - \\
\hline Humerus & UM & - & - & & & 7 & - & - & - & - & - & - & - & - \\
\hline “ & UE & - & 1 & (1) & & 5 & - & - & - & - & - & - & - & - \\
\hline "“ & $\mathrm{F}$ & - & 10 & & (5) & 2 & - & - & - & - & 9 & - & 1 & 1 \\
\hline Radius & UM & - & - & & & 2 & - & - & - & - & - & - & - & - \\
\hline " & UE & 1 & 4 & & & 4 & - & - & - & - & - & - & - & - \\
\hline “" & $\mathrm{F}$ & - & 4 & & & - & - & - & - & - & - & - & - & 1 \\
\hline Metacarpal & UM & - & - & & & - & - & - & - & - & - & - & - & - \\
\hline “" & UE & - & 5 & $\left(2 \frac{1}{1} 2\right)$ & $\left(1 \frac{1}{2}\right)$ & - & - & - & - & - & - & - & - & - \\
\hline$"$ & $\mathrm{~F}$ & - & 2 & & (2) & - & - & - & - & - & - & - & - & - \\
\hline Ischium & & 1 & 4 & & & 1 & - & - & - & - & 4 & - & - & - \\
\hline Femur & UM & - & 1 & & & - & - & - & - & - & - & 1 & - & - \\
\hline “" & UE & - & 4 & & & 2 & - & - & - & - & 1 & 1 & - & - \\
\hline “" & $\mathrm{F}$ & - & 3 & & & - & - & - & - & 1 & 3 & - & - & - \\
\hline Tibia & UM & - & - & & & 2 & - & - & - & - & - & - & 1 & - \\
\hline “" & UE & - & 6 & & & 5 & - & - & - & - & - & - & - & - \\
\hline “" & $\mathrm{F}$ & - & 7 & & & 1 & - & 1 ?id & - & - & 3 & - & - & 1 \\
\hline Calcaneum & $\mathrm{U}$ & 1 & 5 & (1) & (2) & 7 & - & - & - & - & - & - & - & - \\
\hline “" & $\mathrm{F}$ & - & 1 & & (1) & 1 & - & - & - & - & 7 & - & - & 2 \\
\hline “ & $?$ & - & 4 & & (1) & 1 & - & - & - & - & 1 & 1 & - & - \\
\hline Astragalus & & - & 21 & (4) & (8) & 8 & - & - & - & - & 3 & - & - & - \\
\hline Metatarsal & UM & - & - & & & - & - & - & - & - & - & - & - & - \\
\hline “" & UE & 1 & $41 / 2$ & (1) & $\left(1 \frac{1}{2}\right)$ & - & - & - & - & - & - & - & - & - \\
\hline$"$ & $\mathrm{~F}$ & 2 & 3 & $(1 / 2)$ & $\left(2 \frac{1}{1} 2\right)$ & - & - & - & - & - & 6 & - & - & - \\
\hline Phalanx I & UM & 1 & 4 & & & 11 & - & - & - & - & - & - & - & - \\
\hline “" & UE & - & 3 & & & 12 & - & - & - & - & - & - & - & - \\
\hline$"$ & $\mathrm{~F}$ & 1 & 8 & & & 6 & - & - & - & - & - & - & 3 & - \\
\hline Phalanx III & & 3 & 20 & (3) & (11) & 5 & - & 3 & - & - & - & - & - & - \\
\hline Metapodial & $\mathrm{UM}$ & - & $1 / 2$ & & & $1 \frac{1 / 2}{2}$ & - & - & - & - & - & - & - & - \\
\hline “" & UE & 1 & $21 / 2$ & & & $8^{1 / 2}$ & - & - & - & - & - & - & - & - \\
\hline “" & $\mathrm{F}$ & - & $1 / 2$ & & & $1 \frac{1}{2}$ & - & - & - & - & 2 & - & 2 & - \\
\hline Others & & & & & & & & & $\begin{array}{l}2 \text { tooth } \\
\text { frags }\end{array}$ & & & & & \\
\hline
\end{tabular}

TABLE 2

Lameiras Early Neolithic - counts of mammalian bones.

to reflect agricultural improvements (see for example Matolsci, 1970; Audoin-Rouzeau, 1995; Davis \& Beckett, 1999; Colominas et al., 2013; Thomas et al., 2013) and a size reduction, a decline in agricultural standards (Grau-Sologestoa, 2015).
What follows are more detailed descriptions of the Lameiras bones alongside their ancestors and descendants here in southern Portugal. We shall attempt to link their variations in size with the aforementioned factors. 


\begin{tabular}{|c|c|c|c|c|c|c|c|c|c|c|c|c|c|c|}
\hline Bone/tooth & $\mathrm{F} / \mathrm{U}$ & Bos & Ovis/Capra & (Capra) & (Ovis) & Sus & CEE & $\mathrm{CAC}$ & Equus & Lepus & ORC & Canis & Vulpes & Felis \\
\hline $\mathrm{dP}_{4}$ & & 5 & 4 & (2) & (2) & 2 & - & - & - & & & - & - & - \\
\hline $\mathrm{P}_{4}$ & & - & 2 & & & & - & - & - & & & - & - & - \\
\hline $\mathrm{P}_{3 / 4}$ & & - & - & & & - & - & - & - & & & - & - & - \\
\hline $\mathrm{M}_{1}$ & & - & 2 & & & 2 & - & - & - & & & - & - & - \\
\hline $\mathrm{M}_{1 / 2}$ & & 4 & 8 & & & 2 & - & - & - & & & - & - & - \\
\hline $\mathrm{M}_{2}$ & & - & 3 & & & & - & - & - & & & - & - & \\
\hline $\mathrm{M}_{3}$ & & 2 & 1 & & & 2 & - & - & - & & & 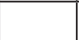 & 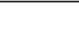 & \\
\hline Mandible & & & & & & & - & - & - & & & 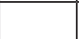 & . & \\
\hline Scapula & $\mathrm{U}$ & - & & & & 2 & - & - & - & - & - & - & - & - \\
\hline “ & $\mathrm{F}$ & & 2 & & & 2 & - & - & - & - & 1 & - & - & \\
\hline " & $?$ & 1 & 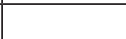 & & & - & - & - & - & - & - & - & - & - \\
\hline Humerus & $\mathrm{UM}$ & - & - & & & 1 & - & - & - & - & - & - & - & - \\
\hline "“ & UE & - & 1 & & & & - & - & - & - & - & - & - & - \\
\hline " & $\mathrm{F}$ & 1 & 2 & & (2) & 1 & - & - & - & - & 6 & - & 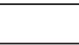 & . \\
\hline Radius & UM & - & 2 & & & & - & - & - & - & - & - & - & - \\
\hline$"$ & $\mathrm{UE}$ & 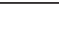 & 5 & & & 1 & - & - & - & - & - & - & - & - \\
\hline$"$ & $\mathrm{~F}$ & - & 1 & & & - & - & - & - & - & - & - & - & \\
\hline Metacarpal & $\mathrm{UM}$ & - & 2 & & & - & - & - & - & - & - & - & - & - \\
\hline " & UE & 1 & 1 & $(1 / 2)$ & & - & - & - & - & - & - & - & - & - \\
\hline " & $\mathrm{F}$ & - & $2 \frac{1}{2}$ & & $\left(2 \frac{1}{2}\right)$ & - & - & - & - & - & - & - & - & - \\
\hline Ischium & & 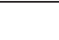 & 2 & & & 1 & - & - & - & - & 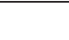 & - & - & - \\
\hline Femur & UM & - & & & & - & - & - & - & - & - & 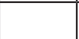 & - & - \\
\hline “ & UE & - & & & & 1 & - & - & - & - & 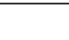 & 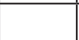 & - & - \\
\hline$"$ & $\mathrm{~F}$ & - & & & & - & - & - & - & 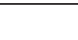 & 1 & - & - & - \\
\hline Tibia & $\mathrm{UM}$ & - & 1 & & & & - & - & - & - & - & - & 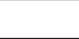 & - \\
\hline “ & UE & - & & & & & - & - & - & - & - & - & - & - \\
\hline " & $\mathrm{F}$ & - & 2 & & & 2 & - & 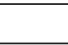 & - & - & 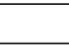 & - & - & 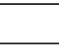 \\
\hline Calcaneum & $\mathrm{U}$ & 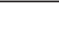 & 3 & & (2) & 1 & - & - & - & - & - & - & - & - \\
\hline$"$ & $\mathrm{~F}$ & - & 1 & & & & - & - & - & - & 1 & - & - & \\
\hline$"$ & $?$ & 1 & 2 & & & 2 & - & - & - & - & & - & - & - \\
\hline Astragalus & & 2 & 11 & (1) & (7) & 7 & - & - & - & - & 3 & - & - & - \\
\hline Metatarsal & $\mathrm{UM}$ & - & - & & & - & - & - & - & - & - & - & - & - \\
\hline " & UE & & $1 \frac{1}{2}$ & & (1) & - & - & - & - & - & - & - & - & - \\
\hline “ & $\mathrm{F}$ & & 2 & & (2) & - & - & - & - & - & 1 & - & - & - \\
\hline Phalanx I & UM & & 3 & & & & - & - & - & - & - & - & - & - \\
\hline “" & UE & 1 & & & & 3 & - & - & - & - & - & - & - & - \\
\hline “ & $\mathrm{F}$ & 5 & 6 & & & 2 & - & - & - & - & - & - & 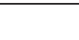 & - \\
\hline Phalanx III & & 1 & 1 & & (1) & 4 & - & 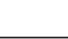 & - & - & - & - & - & - \\
\hline Metapodial & UM & - & & & & $1 / 2$ & - & - & - & - & - & - & - & - \\
\hline$"$ & UE & $1 / 2$ & $1 \frac{1}{2}$ & & $1 / 2$ & $1 \frac{1}{2}$ & - & - & - & - & - & - & - & - \\
\hline$"$ & $\mathrm{~F}$ & $1 / 2$ & & & & $1 \frac{1}{2}$ & - & - & - & - & 1 & - & & - \\
\hline
\end{tabular}

TABLE 3

Lameiras Evolved Early Neolithic - counts of mammalian bones.

\section{Bos - aurochs/cattle}

Domestic cattle are descended from the aurochs, Bos primigenius, probably first domesticat- ed in the Near East. Whether wild cattle in other parts of Europe were independently domesticated is still uncertain, although current evidence points to a Near Eastern origin, at least for European cattle (Edwards et al., 2007). In most parts of Europe 


\begin{tabular}{|c|c|c|c|c|c|c|c|c|c|c|c|c|c|c|}
\hline Bone/tooth & $\mathrm{F} / \mathrm{U}$ & Bos & Ovis/Capra & (Capra) & (Ovis) & Sus & CEE & CAC & Equus & Lepus & ORC & Canis & Vulpes & Felis \\
\hline $\mathrm{dP}_{4}$ & & 5 & 24 & (6) & $(16)$ & 6 & - & - & - & & & - & - & - \\
\hline $\mathrm{P}_{4}$ & & 1 & 23 & & & 3 & - & - & - & & & - & - & - \\
\hline $\mathrm{P}_{3 / 4}$ & & - & - & & & - & - & - & - & & & & - & \\
\hline $\mathrm{M}_{1}$ & & 1 & 33 & (2) & (7) & 5 & - & - & - & & & 1 & - & - \\
\hline $\mathrm{M}_{1 / 2}$ & & 7 & 66 & & & 6 & - & - & - & & & - & - & \\
\hline $\mathrm{M}_{2}$ & & 2 & 31 & & (5) & 4 & - & - & - & & & - & - & \\
\hline $\mathrm{M}_{3}$ & & 5 & 41 & & (1) & 8 & - & - & - & & & - & - & \\
\hline Mandible & & & & & & & & & & - & 6 & . & . & \\
\hline Scapula & $\mathrm{U}$ & - & - & & & 3 & - & - & - & - & - & - & - & - \\
\hline$" “$ & $\mathrm{~F}$ & 1 & - & & & 3 & - & - & - & - & 1 & - & - & - \\
\hline " & $?$ & - & 4 & & & 9 & - & - & - & - & 1 & - & - & - \\
\hline Humerus & UM & - & - & & & 1 & - & - & - & - & - & - & - & - \\
\hline$"$ & UE & - & 1 & & & - & - & - & - & - & - & - & - & - \\
\hline " & $\mathrm{F}$ & 1 & 17 & (2) & (6) & 5 & - & 1 & - & 1 & 4 & - & - & - \\
\hline Radius & UM & - & 2 & & & - & - & - & - & - & - & - & - & - \\
\hline " & UE & - & 5 & & & 2 & - & - & - & - & - & - & - & - \\
\hline$"$ & $\mathrm{~F}$ & - & - & & & - & - & - & - & - & - & - & - & - \\
\hline Metacarpal & UM & 2 & - & & & $1 / 2$ & - & - & - & - & - & - & - & - \\
\hline " & UE & - & $1 / 2$ & $(1 / 2)$ & & - & - & - & - & - & - & - & - & - \\
\hline "“ & $\mathrm{F}$ & 4 & $1 / 2$ & $(1 / 2)$ & & 2 & - & - & - & - & - & - & - & - \\
\hline Ischium & & 1 & 3 & & & 4 & 1 & - & - & 1 & 6 & - & - & - \\
\hline Femur & UM & - & 1 & & & - & - & - & - & - & - & - & - & - \\
\hline " & UE & - & - & & & - & - & - & - & - & - & - & - & - \\
\hline$"$ & $\mathrm{~F}$ & - & - & & & - & - & - & - & - & 3 & - & - & - \\
\hline Tibia & UM & 1 & 3 & & & 4 & - & - & - & - & - & - & - & - \\
\hline " & UE & 1 & - & & & 4 & - & - & - & - & - & - & - & - \\
\hline " & $\mathrm{F}$ & 2 & 5 & & & 4 & 1 & - & - & - & 3 & - & - & - \\
\hline Calcaneum & $\mathrm{U}$ & 2 & 3 & (1) & & 7 & - & - & - & - & 1 & - & - & - \\
\hline$"$ & $\mathrm{~F}$ & - & 1 & & $(1)$ & - & - & - & - & 1 & 4 & - & - & - \\
\hline " & $?$ & 4 & 3 & & (1) & 3 & - & - & - & - & - & - & - & - \\
\hline Astragalus & & 5 & 21 & (4) & $(8)$ & 10 & - & - & - & - & - & - & - & - \\
\hline Metatarsal & UM & - & 1 & & (1) & - & - & - & - & - & - & - & - & - \\
\hline "“ & UE & - & - & & & - & - & - & - & - & - & - & - & - \\
\hline " & $\mathrm{F}$ & 2 & $1 / 2$ & & $(1 / 2)$ & $1 / 2$ & - & - & - & - & 2 & - & - & - \\
\hline Phalanx I & UM & 2 & 3 & & & 3 & - & - & - & - & - & - & - & - \\
\hline$"$ & UE & 1 & 1 & & & 4 & - & - & - & - & - & - & - & - \\
\hline$"$ & $\mathrm{~F}$ & 10 & 4 & & & 15 & - & - & - & - & - & 1 & - & - \\
\hline Phalanx III & & 5 & 3 & (3) & & 8 & - & - & - & - & - & - & - & - \\
\hline Metapodial & UM & - & - & & & - & - & - & - & - & - & - & - & - \\
\hline$"$ & UE & $1 \frac{1}{2}$ & 1 & & & $41 / 2$ & - & - & - & - & - & - & - & - \\
\hline " & $\mathrm{F}$ & $1 \frac{1}{2}$ & 1 & & & $1 \frac{1}{2}$ & - & - & - & - & - & 1 & - & - \\
\hline
\end{tabular}

TABLE 4

Lameiras Late Neolithic - counts of mammalian bones.

and the Near East, distinguishing between bones of the wild and bones of the domesticated forms can be done on the basis of size - with those of the aurochs being considerably larger. However, for certain measurements of certain bones there can be some overlap between small female aurochs and large male domestic cattle. Here in Portugal, in the Iron Age and subsequent periods, there is no secure evidence for aurochs. The aurochs probably became extinct in the Chalcolithic or Bronze Age (Castaños, 1991). Mesolithic Bos (i.e., aurochs) bones are on average considerably larger than Bos 


\begin{tabular}{|c|c|c|c|c|c|c|c|c|c|c|c|c|c|c|}
\hline Bone/tooth & $\mathrm{F} / \mathrm{U}$ & Bos & Ovis/Capra & (Capra) & (Ovis) & Sus & CEE & CAC & Equus & Lepus & ORC & Canis & Vulpes & Felis \\
\hline $\mathrm{dP}_{4}$ & & - & 2 & & (1) & - & - & - & - & & & - & - & \\
\hline $\mathrm{P}_{4}$ & & - & 1 & & & - & - & - & - & & & - & - & - \\
\hline $\mathrm{P}_{3 / 4}$ & & - & - & & & - & - & - & - & & & & & \\
\hline $\mathrm{M}_{1}$ & & - & 1 & & & 1 & - & - & - & & & - & - & - \\
\hline $\mathrm{M}_{1 / 2}$ & & 2 & 9 & & & 2 & - & - & - & & & & & \\
\hline $\mathrm{M}_{2}$ & & - & 1 & & & 1 & - & - & - & & & - & - & \\
\hline $\mathrm{M}_{3}$ & & 2 & 1 & & & 1 & - & - & - & & & - & - & \\
\hline Mandible & & & & & & & & & & - & 2 & & & \\
\hline Scapula & $\mathrm{U}$ & - & - & & & - & - & - & - & - & - & - & - & - \\
\hline “" & F & - & - & & & - & - & - & - & - & - & - & - & - \\
\hline " & $?$ & - & - & & & - & - & - & - & - & 1 & - & - & - \\
\hline Humerus & UM & - & - & & & - & - & - & - & - & - & - & - & - \\
\hline “ & UE & - & - & & & - & - & - & - & - & - & - & - & - \\
\hline " & $\mathrm{F}$ & - & 2 & (1) & (1) & - & - & - & - & - & 1 & - & - & - \\
\hline Radius & UM & - & - & & & - & - & - & - & - & - & - & - & - \\
\hline$"$ & $\mathrm{UE}$ & - & - & & & - & - & - & - & - & - & - & - & - \\
\hline “ & $\mathrm{F}$ & - & - & & & - & - & - & - & - & - & - & - & - \\
\hline Metacarpal & $\mathrm{UM}$ & - & - & & & $1 / 2$ & - & - & - & - & - & - & - & - \\
\hline “ & UE & - & - & & & - & - & - & - & - & - & - & - & - \\
\hline “" & $\mathrm{F}$ & - & - & & & - & - & - & - & - & - & - & - & - \\
\hline Ischium & & - & - & & & - & - & - & - & - & - & - & - & - \\
\hline Femur & $\mathrm{UM}$ & - & - & & & - & - & - & - & - & - & - & - & - \\
\hline “" & UE & - & - & & & - & - & - & - & - & - & - & - & - \\
\hline " & $\mathrm{F}$ & - & - & & & - & - & - & - & - & 1 & - & - & - \\
\hline Tibia & UM & - & - & & & - & - & - & - & - & 1 & - & - & - \\
\hline “" & UE & - & - & & & - & - & - & - & - & - & - & - & - \\
\hline "“ & $\mathrm{F}$ & - & - & & & - & - & - & - & - & 1 & - & - & - \\
\hline Calcaneum & $\mathrm{U}$ & - & - & & & - & - & - & - & - & - & - & - & - \\
\hline " & $\mathrm{F}$ & - & - & & & - & - & - & - & - & 2 & - & - & - \\
\hline " & $?$ & - & - & & & - & - & - & - & - & - & - & - & - \\
\hline Astragalus & & 1 & - & & & 1 & - & - & - & - & - & - & - & - \\
\hline Metatarsal & $\mathrm{UM}$ & - & - & & & - & - & - & - & - & - & - & - & - \\
\hline$"$ & UE & - & - & & & - & - & - & - & - & - & - & - & - \\
\hline “" & $\mathrm{F}$ & - & - & & & - & - & - & 1 ?EQC & - & - & - & - & - \\
\hline Phalanx I & UM & - & - & & & - & - & - & - & - & - & - & - & - \\
\hline “" & UE & - & - & & & - & - & - & - & - & - & - & - & - \\
\hline " & $\mathrm{F}$ & - & 2 & & & 1 & - & - & - & - & - & - & - & - \\
\hline Phalanx III & & - & - & & & 1 & - & - & - & - & - & - & - & - \\
\hline Metapodial & $\mathrm{UM}$ & - & - & & & - & - & - & - & - & - & - & - & - \\
\hline " & UE & - & - & & & $1 / 2$ & - & - & - & - & - & - & - & - \\
\hline "“ & $F$ & - & - & & & $1 / 2$ & - & - & 1 ?EQH & - & - & - & - & - \\
\hline Others & & & & & & & & & $\begin{array}{l}\text { Tooth } \\
\text { frag }\end{array}$ & & & & & \\
\hline
\end{tabular}

TABLE 5

Lameiras Chalcolithic - counts of mammalian bones.

Tables 1 to 5 .

Numbers of teeth and bones recorded in the Mousterian, Early Neolithic, Evolved Early Neolithic, Late Neolithic, and Chalcolithic layers at Lameiras. These are the PoSACs described in Davis (1992, 2002). Single metapodial condyles (Sus metapodials and broken bovid and cervid metapodials) are counted as halves, for example in the Late Neolithic there were 9 unfused Sus metapodial epiphyses; hence the number given is $4 \frac{1}{2}$. Taxa are abbreviated as follows: 'Bos' - cattle and wild cattle (B. taurus/primigenius); 'Ovis/Capra' - caprine bones 
that could not be identified to species as well as those that could be identified as either sheep (Ovis) or goat (Capra), thus in the Late Neolithic, of the 21 caprine astragali, 4 were definite goat, 8 definite sheep and nine unidentified sheep or goat; 'Sus' - wild boar and pig; 'CEE' - red deer, Cervus elaphus; 'CAC' - roe deer, Capreolus capreolus; 'Equus' - both horse, E. caballus (EQC) and Otranto ass, E. hydruntinus (EQH); 'Lepus' - hare; 'ORC' - rabbit, Oryctolagus cuniculus; Canis - dog and wolf; 'Vulpes' - fox; and 'Felis' - cat, Felis silvestris. The bone fusion symbols are: 'F' - epiphysis fused (adult), 'UE' and 'UM' - unfused epiphysis and metaphysis respectively (juvenile). 'U' refers to scapulae with unfused coracoid or calcaneum with unfused tuber calcis.

\section{Chalcolithic}

Partridge, Alectoris cf rufa (1 coracoid, 1 tarso-metatarsus).

Late Neolithic

Toad, Bufo (several limb-bones);

Lizard, Lacerta (1 mandible).

\section{Mixed Early and Late Neolithic}

Great bustard, Otis tarda (1 proximal phalanx).

Early Neolithic

Amphibian limb-bones ( $9 ; 4$ of which are Bufo bufo);

Pond turtle, Mauremys (1 plastron fragment) ;

Lizard, Lacerta (1 mandible);

Buzzard - probable Goshawk, Accipiter cf gentilis (1 radius) and probable Common buzzard, Buteo buteo (1 tarso-metatarsus);

Hedgehog, Erinaceaus europaeus (3 mandibles);

Field mouse, Apodemus (3 lower first molar teeth M1);

Water vole, Arvicola sapidus (1 mandible).

\section{$\underline{\text { Mousterian }}$}

Amphibian, Bufo bufo (numerous limb bones);

Mole, Talpa (numerous humeri);

Vole lower first molar tooth M1 (Microtus cf. cabrerae and M. cf. lusitanicus).

TABLE 6

Other vertebrate remains, except fish, found at Lameiras.

\begin{tabular}{|c|c|c|c|c|c|c|c|c|c|c|}
\hline \multirow{2}{*}{ Taxon } & \multicolumn{2}{|c|}{ Mousterian } & \multicolumn{2}{|c|}{ E. Neol. } & \multicolumn{2}{|c|}{ E. E. Neol. } & \multicolumn{2}{|c|}{ L. Neol } & \multicolumn{2}{|c|}{ Chalcolithic } \\
\hline & $\mathrm{N}$ & $\%$ & $\mathrm{~N}$ & $\%$ & $\mathrm{~N}$ & $\%$ & $\mathrm{~N}$ & $\%$ & $\mathrm{~N}$ & $\%$ \\
\hline Caprines (sheep/goat) & 1 & - & 177 & 48 & 75,5 & 49 & 302,5 & 56 & 17 & - \\
\hline (Sheep $^{*}$ & - & & 44,5 & & 20 & & 33,5 & & 2 & ) \\
\hline (Goat ${ }^{*}$ & - & & 14 & & 3,5 & & 17 & & 1 & ) \\
\hline Cattle/aurochs & 2 & - & 15 & 4 & 21 & 14 & 68 & 13 & 5 & - \\
\hline Pig/wild boar & - & - & 117,5 & 32 & 41,5 & 27 & 130 & 24 & 9,5 & - \\
\hline Equid & 10 & - & + & & 0 & & 0 & & 2 & - \\
\hline (Horse & - & & 0 & & - & & 0 & & 1 & ) \\
\hline (E. hydruntinus & - & & 0 & & - & & 0 & & 1 & ) \\
\hline Red deer & 2 & - & 0 & & 0 & & 2 & + & 0 & - \\
\hline Roe deer & - & - & 5 & 1 & + & + & 1 & + & 0 & - \\
\hline Hare & 1 & - & 0 & & 0 & & 3 & 1 & 0 & - \\
\hline Rabbit & 15 & - & 43 & 12 & 15 & 10 & 31 & 6 & 9 & - \\
\hline Dog/wolf & - & - & 2 & + & 0 & & 3 & 1 & 0 & - \\
\hline Cat & - & - & 6 & 2 & 0 & & 0 & - & 0 & - \\
\hline Fox & - & - & 7 & 2 & 0 & & 0 & - & 0 & - \\
\hline Total & 31 & & 372,5 & & 153 & & 540,5 & & 42,5 & \\
\hline
\end{tabular}

${ }^{*}$ For the sheep and goat counts, in italics, only $\mathrm{dP}_{4}$, humerus, metacarpal, astragalus, metatarsal and terminal phalanx are counted - these are the parts that can often be determined to species. Note that the counts of caprines include caprines not identified to species (sheep or goat) and parts identified as definite sheep or definite goat. The counts of equids include equids not identified to species (horse or $E$. hydruntinus) and parts identified as definite horse or definite E. hydruntinus. These like the sheep and goat are shown in italics. E.E.Neol refers to bones found in the south sector in a stratigraphically distinct layer that is assigned to the later part of the Early Neolithic.

\section{TABLE 7}

A listing of the medium and large size mammals at Lameiras; ' $\mathrm{N}$ ' is the number of recorded teeth and bones and percentages (emboldened) are calculated to the nearest whole number. 

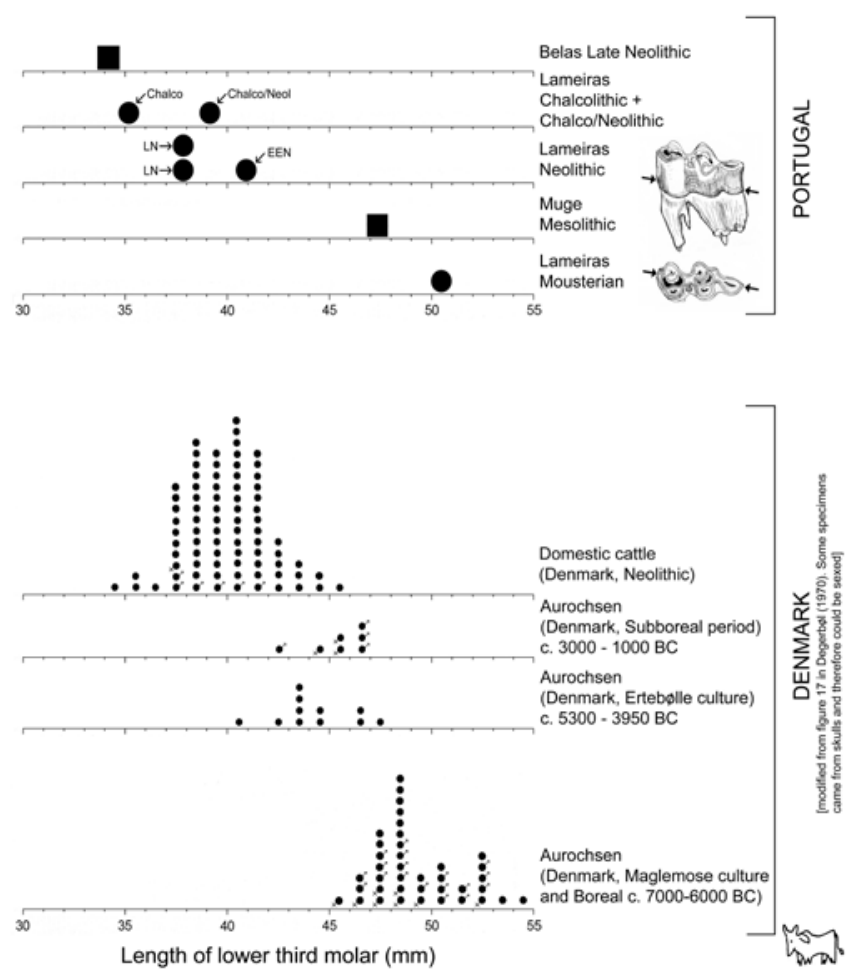

FIGURE 2

Variation in size of Bos - aurochs and cattle. Chronological size change - the length of the lower third molar tooth $\left(\mathrm{M}_{3}\right)$ - in late Pleistocene and early Holocene Portugal, above, and in early Holocene Denmark (Degerbøl, 1970), below. Degerbøl wrote that he always measured his teeth "at the basal part", due to the variation according to the place where the measurement is taken, and so he took his measurements in the same way as the Portuguese ones here.

Portugal - the six Bos $\mathrm{M}_{3} \mathrm{~s}$ from Lameiras, one Mousterian (this large specimen is also shown in Figure 29), three Neolithic (LN = Late Neolithic, EEN = Evolved Early Neolithic) and one Chalcolithic and another Chalcolithic/Neolithic, a single aurochs M3 from Mesolithic Muge (from Cleia Detry) and the Late Neolithic specimen from Belas, near Lisbon (own data unpublished).

Denmark - a simplified version of figure 17 from Degerbøl \& Fredskild (1970). This shows their difference in size associated with domestication - i.e., between aurochsen and cattle. It also shows a decrease in size of aurochsen during the Mesolithic - the Boreal/ Maglemosian aurochsen being larger than the few Subboreal/Ertebølle ones. However, in the absence of late Pleistocene specimens, there is no indication of a Pleistocene - Early Holocene size difference as occurred in other regions such as the Near East (Davis, 1981).

bones from Iron Age to Medieval-Moslem periods with little overlap. In the Iberian Peninsula, like the Near East (Davis, 1981), the late Pleistocene aurochs was larger still - presumably adapted to the lower temperature at the end of the Pleistocene - a case of what Bergmann (1847) first wrote about.

Figures 2 to 6 are stacked histograms of measurements of Bos teeth and bones from late Pleistocene to present day Portugal and sites in neighbouring parts of Spain as well as Denmark and England. These show a) the extent to which it is possible to distinguish metrically between aurochs and cattle and b) the size variation of Bos in the south-western part of the Iberian Peninsula from late Pleistocene times through to the present day - a history that is proving both complicated and interesting.

One measurement that is useful for making the wild-domestic distinction in archaeological remains of Bos, is the length of the lower third molar tooth $\left(\mathrm{M}_{3}\right)$. This is not only because teeth are often well preserved but in most artiodactyls molars show little sexual size-dimorphism (see for example Degerbøl, 1963 and Degerb $\varnothing 1$ \& Fredskild, 1970: 87 for Bos and Payne \& Bull, 1988 for Sus and figure 6.1 in Steele, 2002 for Cervus). This means that any average size differences are real ones and not ones due to an imbalance in the sex ratio in one or other of the samples being com- 

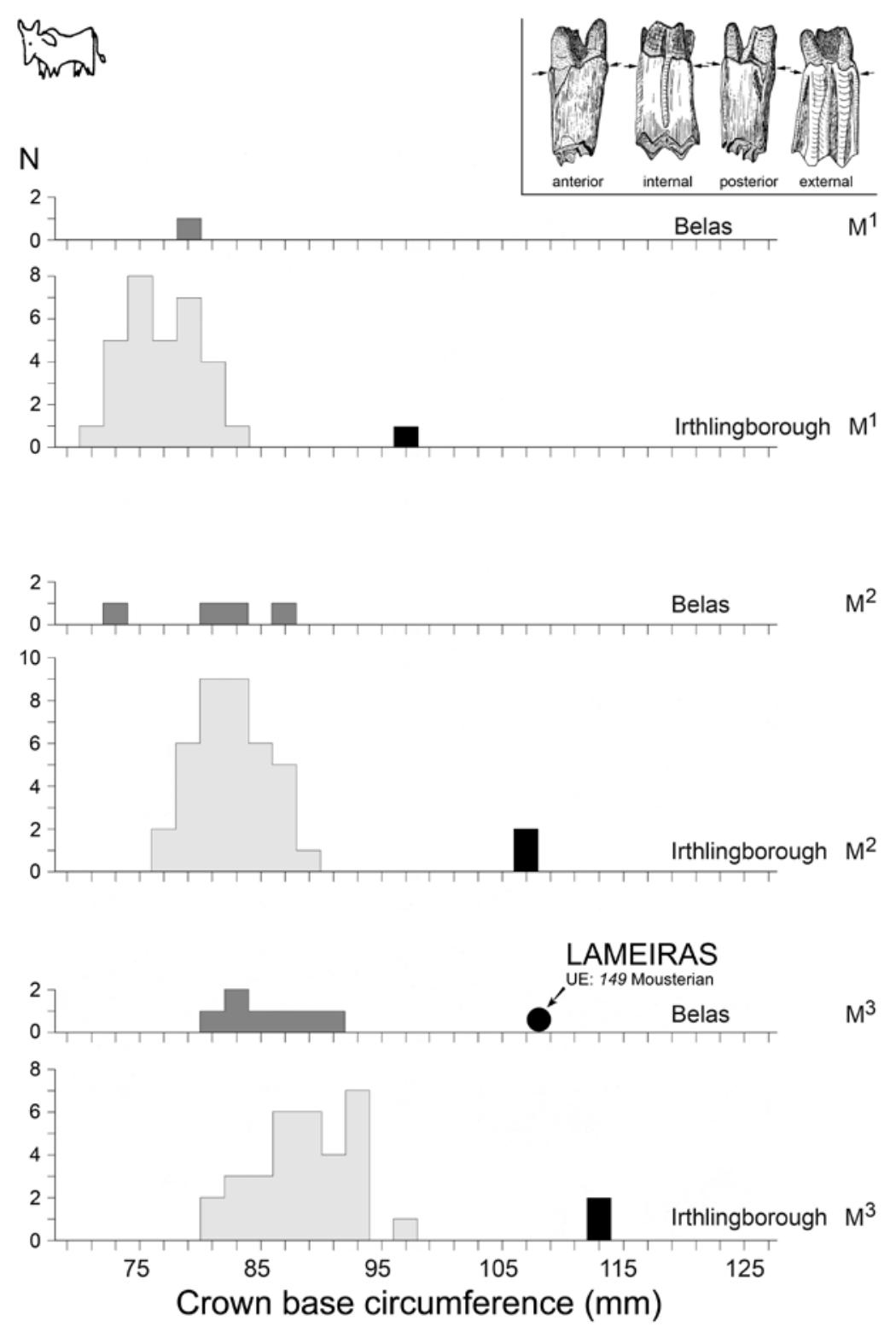

FIGURE 3

Odontometric distinction between cattle and aurochsen upper molar teeth. Plots of the circumferences of the base of the crown of $\mathrm{M}_{1}, \mathrm{M}_{2}$ and $\mathrm{M}_{3}$ from Early Bronze Age Irthlingborough, southern England, compared with one first, four second, and seven third upper molars from late Neolithic Belas (Lisbon region) and the single upper third molar from Lameiras (UE-149; Mousterian). At Irthlingborough most of the molars, shown in light grey, are considered to have belonged to cattle while one first, two second and two third molars, shown in black, and of considerably greater size, are identified as aurochs - Bos primigenius. Inset: the four sides of an isolated $\mathrm{M}^{2}$ to show how the dental circumference is measured by winding cotton thread around the crown base (arrowed, as described in Davis \& Payne, 1993).

pared. Magnus Degerbøl (Degerbøl \& Fredskild, 1970) pioneered the study of early Holocene size variation of aurochsen and domestic cattle in his monograph on the Bos from Denmark. Many were preserved as entire skeletons that could therefore be sexed. With his careful inclusion of measurements, graphs and figures his study serves as a useful benchmark against which we can compare our Bos specimens from Lameiras and southern Portugal. Figure 2 shows Portuguese Bos $\mathrm{M}_{3}$ lengths 


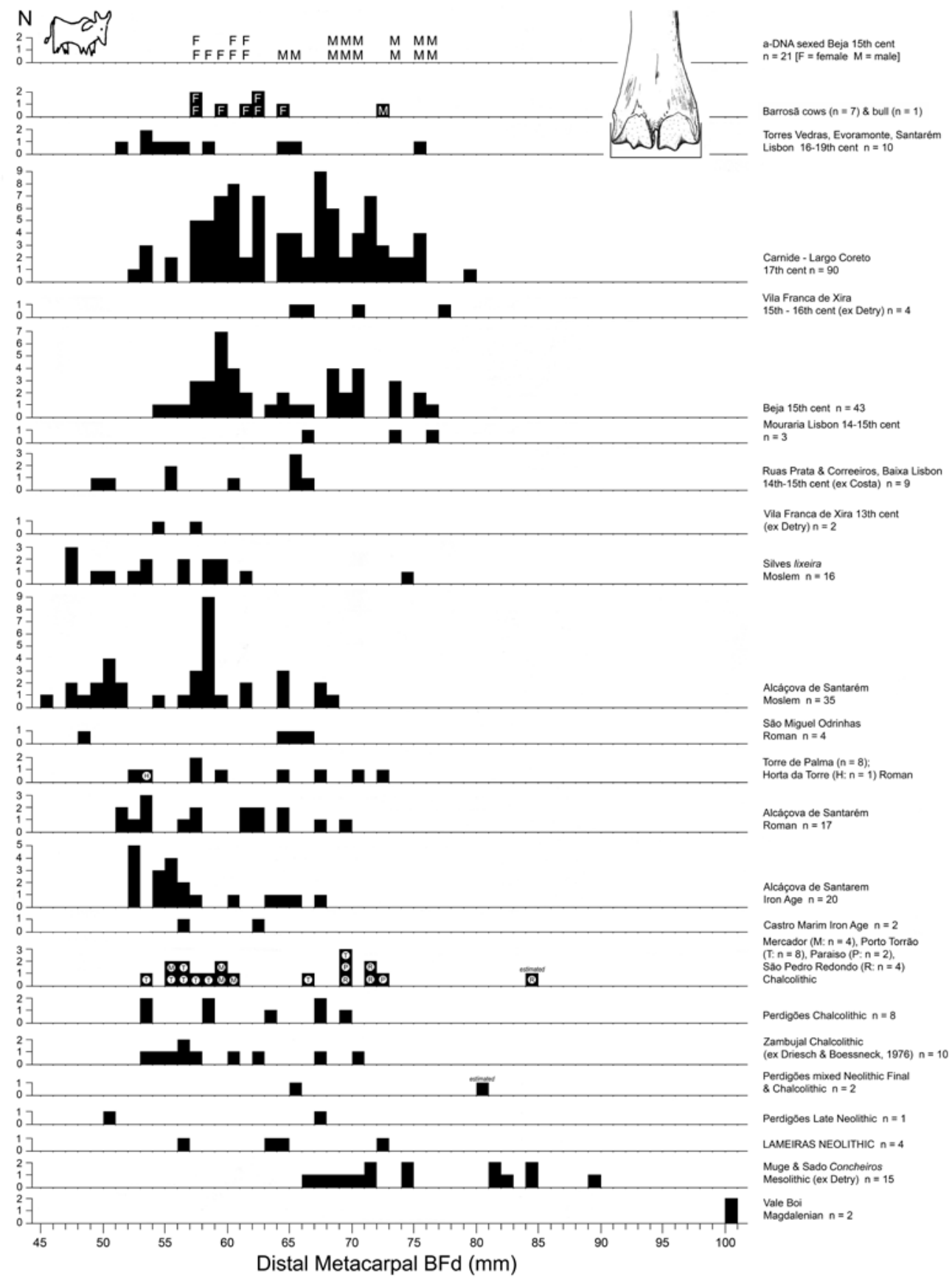

FIGURE 4

Chronological changes in size of aurochs and cattle in Portugal. Stacked histograms of measurements of the distal width (BFd) of metacarpals. The sex of the owners of 21 of the Beja metacarpals was ascertained via their ancient DNA and the results are shown on the top (see Davis et al., 2012). They indicate the degree of sexual size dimorphism exhibited by cattle metacarpals. "N" refers to sample size. On average the Mesolithic aurochsen were larger than the 10 from Zambujal - the latter all presumably domestic cattle. The lack of aurochs metacarpals from Chalcolithic sites (there may only be one from São Pedro, Redondo) makes it difficult to see the Mesolithic - Chalcolithic size increase observable in the astragali (see Figures 5 and 6). Three of the Lameiras metacarpals are small and almost certainly belonged to domestic cattle while the largest is uncertain wild or domestic. Note the very large specimens from Late Pleistocene Vale Boi, and the size increase after the Moslem period probably reflecting Christian improvements of this animal. 


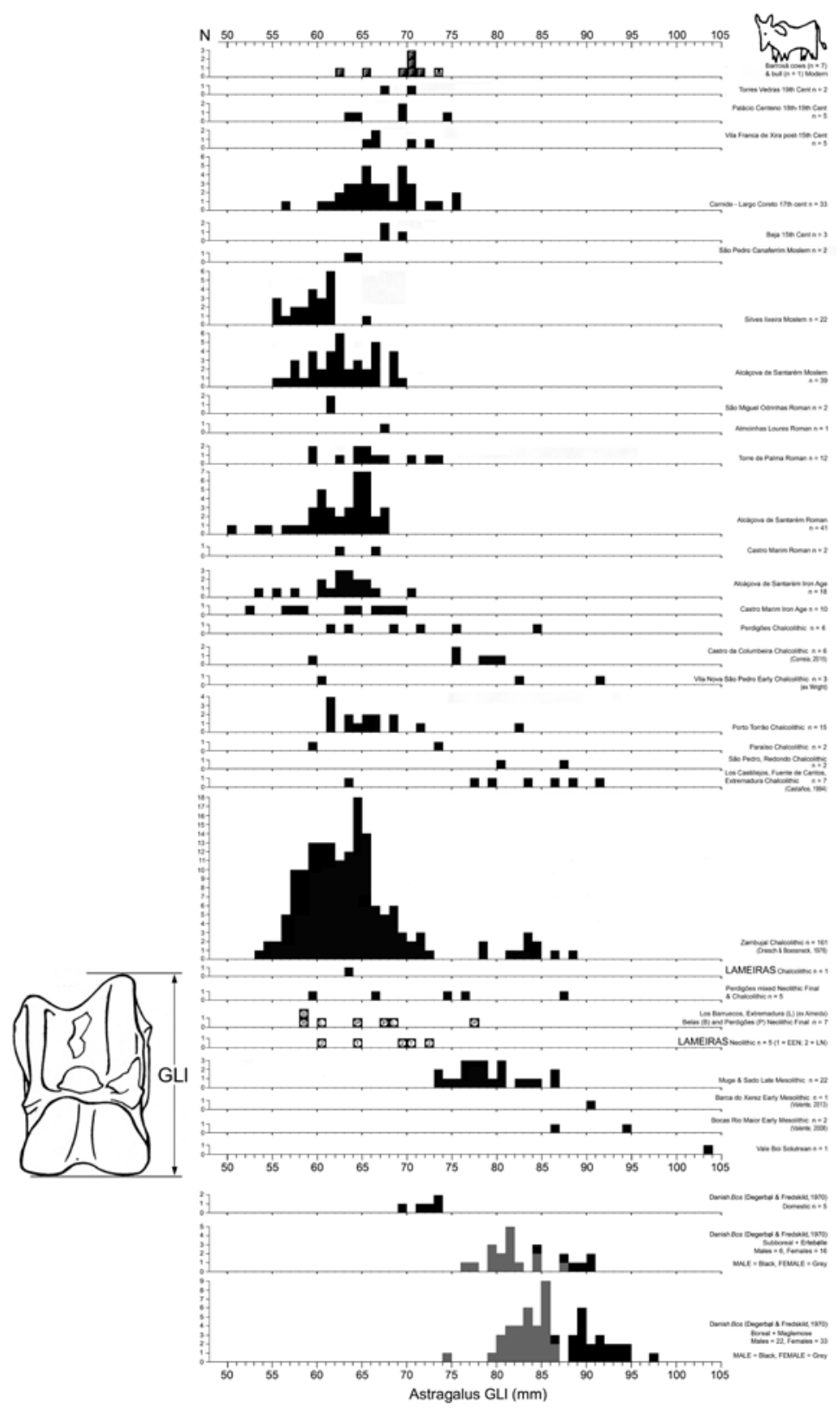

FIGURE 5

Chronological changes in size of Bos (aurochs and cattle) in Portugal (and SW Spain) above and Denmark below. These are stacked histograms of measurements of the greatest lateral lengths (GLl) of astragali. "N" refers to sample size.

Below are Danish early Holocene Bos (from table 19; Degerbø1 \& Fredskild, 1970). Note:

a) A slight decrease in size of the early Holocene aurochsen - compare the Boreal+Maglemose and the Subboreal+Ertebølle and

b) A second and more significant decrease in size associated with domestication. However, as with the third molar teeth (Figure 2), in the absence of late Pleistocene specimens, any presumed Pleistocene - Early Holocene size reduction cannot be registered.

Above are specimens from sites in southern Portugal and neighbouring SW Spain (Extremadura). Tiina Manne allowed SJMD to measure the aurochsen astragali from Vale Boi. Measurements from Barca do Xerez, Bocas Rio Maior, Los Castillejos, Peña Cabarga, and Zambujal are in Valente (2013), Valente (2008), Castaños (1994); Castaños et al. (2012), and Driesch \& Boessneck (1976) respectively. The two astragali from Belas (unpublished; Late Neolithic) measure 58,0 and 58,7 mm. The small size of the six Lameiras specimens, five Neolithic and one Chalcolithic, indicates these belonged to domesticated cattle. 


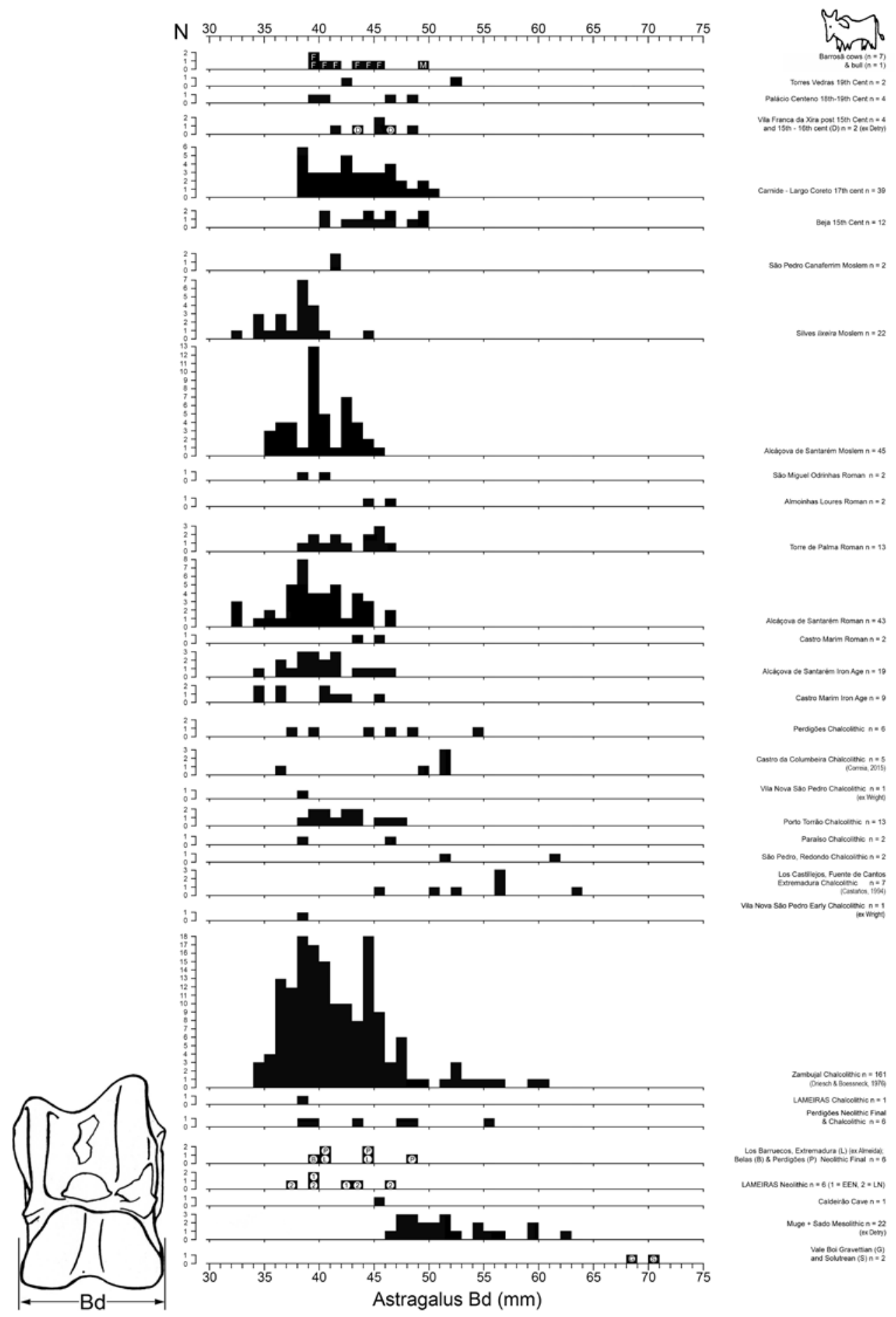

FIGURE 6

Chronological changes in size of Bos (aurochsen and cattle) in Portugal (and SW Spain). Stacked histograms of measurements of the distal width $(\mathrm{Bd})$ of astragali. These show similar size trends as those shown by astragalus GLl in Figure 5 whose legend provides further details. 
(above) and those of aurochsen and domestic cattle from Holocene Denmark (below - from figure 17 in Degerb $\varnothing 1$ \& Fredskild, 1970). Some of these Danish specimens were from skulls and could therefore be sexed by Degerb $\varnothing 1$ and indeed show little sexual size dimorphism. This means that it is probably safe to ignore sex as a complicating factor when comparing $\mathrm{M}_{3}$ s from different periods. In the Portuguese sample there is one very large specimen from the Mousterian (late Pleistocene) of Lameiras, a smaller one at Mesolithic Muge (early Holocene) and six considerably smaller ones in Neolithic Lameiras and Belas (the latter a Late Neolithic site in the Lisbon peninsula) and Chalcolithic Lameiras. As for the astragali (with many more specimens to illustrate what was happening; see below) it is already possible in this admittedly very small sample of teeth to discern at least three size groups - very large late Pleistocene wild Bos, smaller Holocene wild Bos (the Mesolithic specimen) and smaller still presumably domestic Bos in the Neolithic and Chalcolithic. Geographical comparisons are also interesting: note that the late Pleistocene (Mousterian) specimen from Lameiras is similar in size to the early Holocene (Maglemose/Boreal) aurochsen from Denmark. If late Pleistocene aurochsen in northern Europe were larger still, then there must have been a geographical size cline of aurochsen from southern Europe (smaller) to northern Europe (larger). In other words Bos showed or shows both a geographical and a chronological correlation between environmental temperature and body size. That the aurochs showed increasing size with latitude in Europe has recently been confirmed, admittedly tentatively in view of the small sizes of some of the samples, by Wright \& Viner-Daniels (2015).

Figure 3 shows the circumferences of upper molar teeth measured at the base of the crown - note the upper third molar from the Mousterian of Lameiras alongside those from Late Neolithic Belas and from Bronze Age Irthlingborough in southern England (Davis \& Payne, 1993). It was these measurements of tooth crown circumferences from Irthlingborough that enabled distinction between cattle and aurochs upper molars. The 12 molars from Belas, all of small size, and shown in dark grey, are more likely therefore to have belonged to cattle. The single Mousterian $\mathrm{M}^{3}$ from Lameiras (stratigraphic unit 149), being large, is identified as aurochs.

Figure 4 shows plots of metacarpal distal widths, and Figures 5 and 6 show plots of astragalus lengths

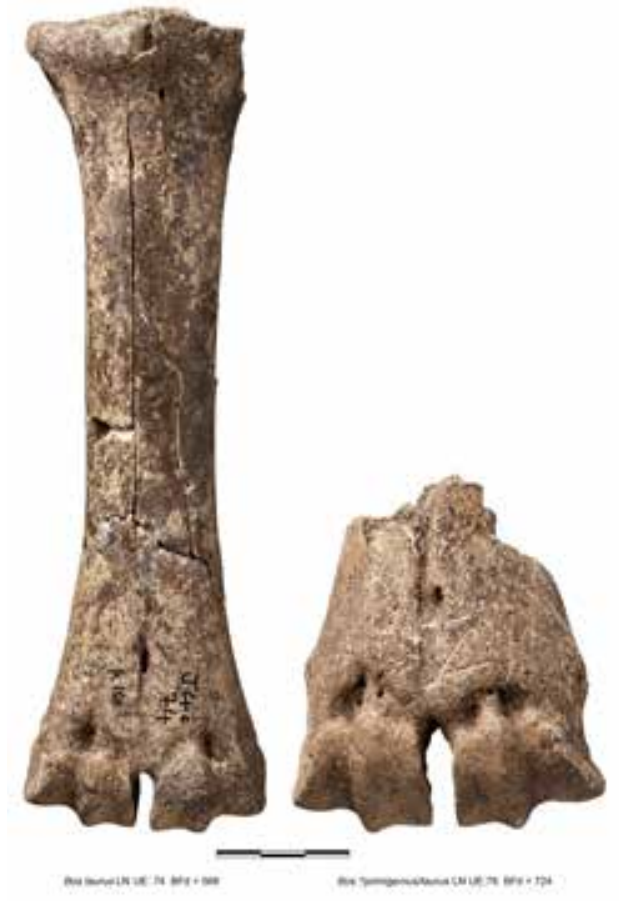

FIGURE 7

Two Bos metacarpals in anterior view from Late Neolithic Lameiras. The entire metacarpal on the left is small and almost certainly belonged to domestic cattle. The considerably larger specimen on the right is the largest Bos metacarpal found at Neolithic Lameiras and may well have belonged to an aurochs, Bos primigenius. See also Figure 4 . The measurements $\mathrm{BFd}$ are given in tenths of a millimetre.

and widths from southern Portuguese (and some neighbouring Spanish) Bos, from the Upper Pleistocene to the present day. Figure 7 shows two of the Lameiras Bos metacarpals, one almost certainly domestic and the other, a distal fragment, probably an aurochs. Figure 8 shows five Bos astragali. It is difficult visually to ascertain their wild/domestic status. The specimen shown at the bottom from the Late Neolithic (UE 74) is rather large and could well have belonged to an aurochs (see also Figure 6).

The aurochs - cattle distinction is fairly clear although measurements of some bones probably do show an overlap between wild and domestic forms. If we look closely at the plots for the Zambujal astragali there does not appear to have been any overlap as Driesch \& Boessneck (1976) found. And as they suggested, astragali with greatest lateral length (GLl) exceeding $75 \mathrm{~mm}$ belonged to aurochsen. Their scatter diagram ('Diagramm 2') of astragalus measurements, shows a complete separation of presumed aurochs from presumed domestic cattle 

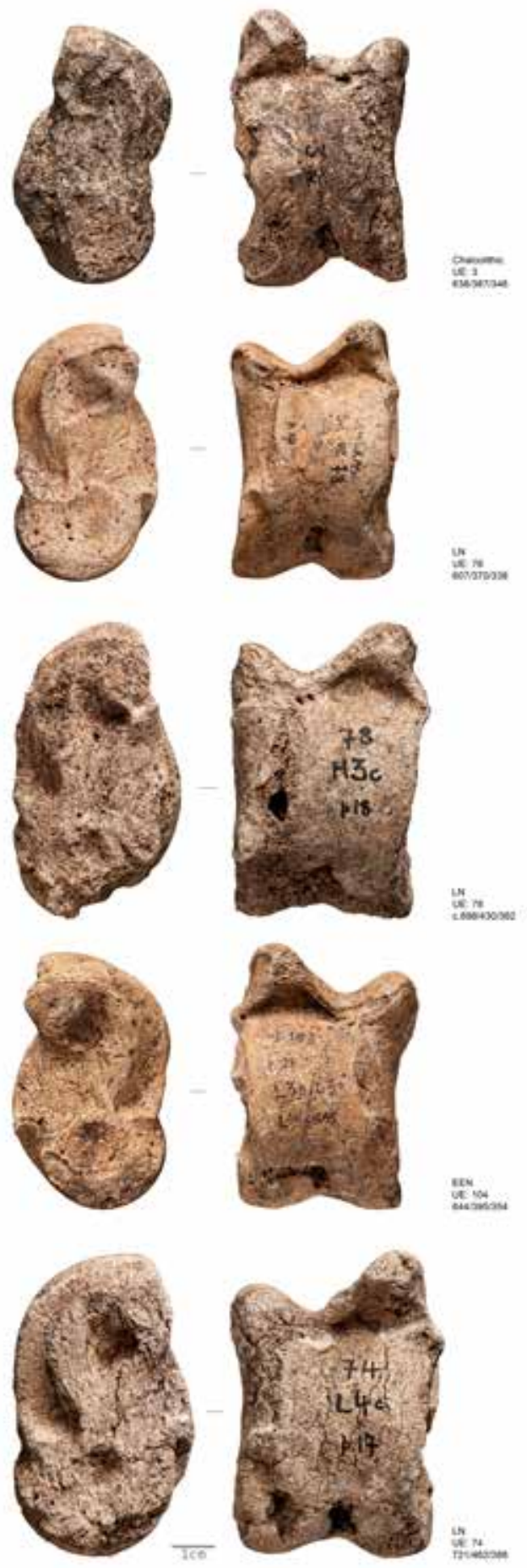

FIGURE 8

Medial and plantar views of five Bos astragali. The measurements in tenths of a millimetre are given as follows - GLl/Bd/Dl. They probably belonged to domestic cattle. specimens with a clear gap between the two forms. When the plots for the Bos astragali from Lameiras are compared to the Pleistocene, Mesolithic, and Chalcolithic specimens as well as those from subsequent periods, it is quite clear that all Neolithic Lameiras specimens (two are from the EEN and the others are Late Neolithic) and the single one from Chalcolithic Lameiras, belonged to domestic cattle and are too small to have been aurochsen. A careful perusal of Figures 5 and 6 reveals that Bos astragalus measurements in Upper Pleistocene to recent Portugal (and neighbouring sites in Spain) appear to fall into five different size-groups. They are:

1) Late Pleistocene aurochsen: very large

2) Mesolithic aurochsen: considerably smaller than late Pleistocene aurochsen

3) Chalcolithic aurochsen: still considerably smaller than late Pleistocene aurochsen but slightly larger than Mesolithic aurochsen

4) Neolithic to Medieval-Moslem period cattle: considerably smaller than Mesolithic aurochsen

5) Post-Moslem period (i.e., following the Christian 'reconquista') cattle: slightly larger than Medieval-Moslem period cattle but never as large as aurochsen.

What follows below is a discussion of these groups in chronological order and an attempt to speculate on what were the factors responsible for these size differences.

Very_large Pleistocene aurochsen - from Vale Boi (note the two metacarpals and the two astragali) and from several Pleistocene sites in Spain (Madrid, Cantabria, Cataluña and León regions - data kindly sent to us by Spanish colleagues, but not shown here) were also large and considerably larger than the aurochsen from the Holocene (both Mesolithic and Chalcolithic). Thus, as in the Near East and elsewhere (see above), aurochsen in southern Portugal also underwent a size decrease at the end of the last Ice Age when temperatures increased. This Pleistocene-Holocene size reduction - contemporary with temperature increase - has also been documented for the abundant collections of rabbits in southern Portugal (Davis \& Moreno-García, 2007).

Smaller late Mesolithic aurochsen - from the Muge and Sado shell middens. Note that these were not only very much smaller than their Pleistocene ancestors but they are also slightly smaller 
than Chalcolithic aurochs - their wild descendants (see below). The three specimens from the two early Mesolithic sites - Bocas Rio Maior and Barca do Xerez - are large compared to those from the late Mesolithic sites at Muge and in the Sado estuary (their GLl measurements are in Figure 5). Admittedly these are too few specimens to make any definitive conclusions, but they do prompt the question - does this reflect size decrease of aurochsen $\underline{\text { during }}$ the Mesolithic? It is a question that is worth asking as Degerbøl \& Fredskild's (1970) measurements of aurochsen from Boreal/Maglemose versus aurochsen from sub boreal/Ertebølle (i.e., early versus late Mesolithic) show a small decrease in size (see Figure 2 for $M_{3}$ lengths and Figure 5 for astragalus GLl). In a recent survey of ungulates from Mesolithic sites in South Scandinavia, Magnell (in press) suggests that aurochsen on Zealand were depleted by the end of the Maglemose. He notes the higher frequencies of both roe deer and wild boar on Late Mesolithic sites in coastal regions which he links with these animals' higher rates of reproduction making them less sensitive to high hunting pressure. Put another way, it would seem possible that over a period of several (perhaps four or five) millennia the aurochsen both in Denmark and here in the south-western part of the Iberian Peninsula underwent a gradual size decrease due to overhunting and subsequently (in Portugal at least) recovered some of their former size as we shall now discuss.

Slightly_larger aurochsen that survived after the Mesolithic but probably became extinct in the Chalcolithic or soon thereafter. These Chalcolithic aurochsen as represented by the small separated peak of 11 specimens on the right at Zambujal, the six specimens from Los Castillejos (Fuente de Cantos, Extremadura, Spain; Castaños, 1994), the two specimens from São Pedro Redondo, and one or both of the larger specimens from Vila Nova São Pedro (measurements supplied by Elizabeth Wright), are slightly larger on average than their Mesolithic ancestors. Note the approximate increase in the mean value of astragalus GLl from c. $79 \mathrm{~mm}$ in the Mesolithic to c. $83 \mathrm{~mm}$ in the Chalcolithic - the latter value being the average GLl of the 11 presumed aurochsen at Zambujal.

This small but statistically significant size increase of the aurochs after the Mesolithic is discussed in Davis \& Mataloto (2012) and Davis \& Detry (2013) who suggest it was due to a relaxation of the intense hunting pressure that occurred in the
Mesolithic. Thus the excessive small size in the Mesolithic (as is the case also for wild boar and red deer) may reflect overhunting at that time - a probable period of crisis both here in southern Portugal and perhaps right across southern Europe and the Near East.

As for the larger Bos bones from Lameiras, the larger of the two distal metacarpals shown in Figure 7 with a distal width of $72,4 \mathrm{~mm}$ could have belonged to an aurochs.

Domestic Bos. In Figure 5 the metrical distinction between the larger aurochsen and smaller domesticated cattle is clearly visible at Chalcolithic Zambujal with its two separate peaks separated by the gap between 73 and $78 \mathrm{~mm}$ in Driesch \& Boessneck's (1976) 'Diagramm 2'. Domestic cattle first appear in the Neolithic (even in the Early Neolithic, see below in the general discussion) at Lameiras. Note the five astragali from Evolved Early Neolithic and Late Neolithic Lameiras, and several from Los Barruecos, Belas and Perdigões in Figures 2, 4, 5 and 6 . Domesticated cattle are also well represented by a single astragalus at Chalcolithic Los Castillejos (in Figures 5 and 6), and several specimens from other Chalcolithic sites (Paraiso, Porto Torrão, Vila Nova São Pedro and a single one from Castro da Columbeira) and numerous ones in the Iron Age, Roman and Medieval-Moslem periods.

The post-Medieval cattle that were larger - at $15^{\text {th }}$ century Beja and $17^{\text {th }}$ century Carnide, Lisbon and small samples from other post-Moslem sites. These are presumed to be cattle that had been improved by the Christians after the reconquista (Davis, 2008).

Thus the three lower third molars, at least two or three of the distal metacarpals, four or even all six astragali (some poorly preserved and therefore lacking some measurements) and several metatarsal condyles of Bos from Neolithic Lameiras with their small size represent early evidence for the presence of domestic cattle in Portugal.

\section{Ovis/Capra - sheep/goat}

A considerable proportion of the medium/large mammal remains found at Lameiras belonged to caprines - sheep and goat. These two related genera of bovids are both classified within the sub-fami- 
ly Caprinae and tribe caprini. Despite a probable 7 million year separation of the lineages that gave rise to sheep and goat (i.e., in the late Miocene; Randi et al., 1991; Bibi, 2013), many of their bones are difficult to identify to species.

The sheep is considered to have been domesticated in the Near East from the Asiatic mouflon, Ovis orientalis, of Turkey and western Iran. It is this species of wild sheep that has the same karyotype or number of chromosomes, 54, as our domestic sheep (Zeuner, 1963; Nadler et al., 1973). Mitochondrial DNA analyses corroborate the karyotype studies (Hiendleder et al., 2002). Sheep were absent from Europe before their sudden arrival in the Neolithic - an event presumably brought about by man and which marks their domesticated status. The presence of Ovis bones on an archaeological site in Western Europe therefore serves as a sure indicator of its domesticated status and sheep remains are, along with the other main domestic food animals like goat, pig and cattle, as well as cereals, part of the 'Neolithic package' used by archaeologists to recognize a food producing economy. Wild goats, the so-called 'Spanish ibex' or Capra pyrenaica, were once quite common in Iberia, although today they are restricted to mountainous regions of the Peninsula. Since bones of Capra and Ovis are not easy to distinguish and most caprine bones can only be determined as "sheep/goat", it is necessary here to consider carefully the various characters, both morphological and osteometrical, which can help to determine with certainty the caprine bones from Lameiras as definite sheep or definite goat. Zeder \& Lapham (2010) showed experimentally just how difficult it is to make this distinction. Small morphological differences on the distal humerus, distal metacarpal, calcaneum, astragalus, distal metatarsal and terminal phalanx described by Boessneck et al. (1964) and Boessneck (1969) are often quite useful when identifying archaeological caprine bones and are referred to here. Use of these criteria enabled Rowley-Conwy (1992) to identify six of the 20 caprine fragments from Neolithic Caldeirão as sheep while none could be assigned to goat. The mandibular milk teeth, $\mathrm{dP}_{3}$ and $\mathrm{dP}_{4}$, can also be separated (Payne, 1985), and measure-

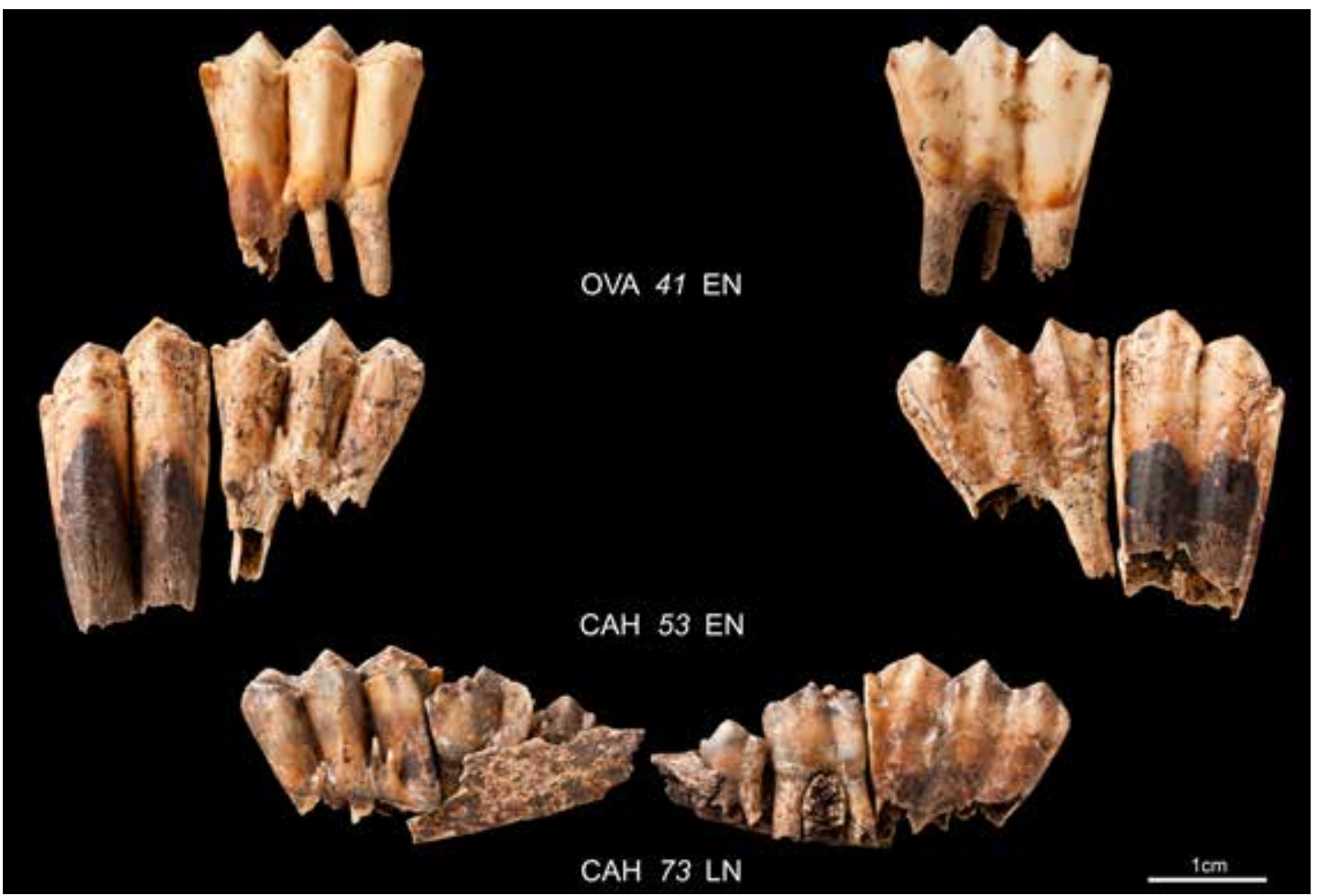

FIGURE 9

Milk teeth of one lamb (OVA) and two kids (CAH) shown in buccal view on the left and lingual view on the right. Note the marked presence of one or more 'bovine pillars' at the base of the $\mathrm{dP}_{4}$ crown of the two specimens identified as Capra. Bovine pillars are absent from the $\mathrm{dP}_{4}$ identified as Ovis (see Payne, 1985). 
ments can help in the case of the distal metacarpal (Payne, 1969) and the astragalus (Davis, 2016, 2017). What follows are more detailed descriptions of certain parts of these bones that confirm their identification as either sheep or goat. Then some consideration will be given to the two metrical methods used to separate sheep from goat metacarpals and astragali. The final part of this section places the Lameiras sheep and goats within a longer chronological sequence.

\section{MORPHOLOGICAL METHODS TO DISTINGUISH SHEEP BONES FROM GOAT BONES (SEE FIGURES 9 TO 13 WHICH SHOW VARIOUS CAPRINE BONES FROM LAMEIRAS).}

Last deciduous molar tooth or $\mathrm{dP}_{4}$. One character that separates goat $\mathrm{dP}_{4}$ from sheep $\mathrm{dP}_{4}$ is the presence or absence of the so-called bovine pillar(s) on the buccal side and at the base of the crown (Payne, 1985). Three well preserved $\mathrm{dP}_{4} \mathrm{~s}$ are shown in Figure 9. Note the prominent bovine pillar on two of the specimens (UE-53; and 73) - which are therefore identified as goat. Note also the absence of any pillar on the third specimen (UE - 41) which presumably therefore belonged to a sheep.

Distal humerus. In sheep, the distal part of the medial epicondyle - labelled ' $a$ ' in Figure 10 - ends more or less as a right angle whereas this tends to be oblique in the goat. Note in this figure that the two distal humeri identified as probable goat have oblique medial epicondyles while the four shown below have right angled epicondyles and are therefore identified as sheep. Another character that tends to distinguish the trochleae of sheep from goat is the relatively small minimum diameter (measurement HTC) in the goat. Of the two probable goat humeri in Figure 10 both have rather reduced HTCs, i.e., constricted trochleae. This is especially visible in the second one from UE 4. Compare it for example to the one below (UE 27) identified as sheep.

Distal metacarpal. Figure 11 shows a young goat and two adult sheep distal metacarpals. In this bone the two peripheral parts of the trochlear condyles - labelled with arrows in the figure - are considerably more compressed compared to the central condyles in the goat than in the sheep. It is
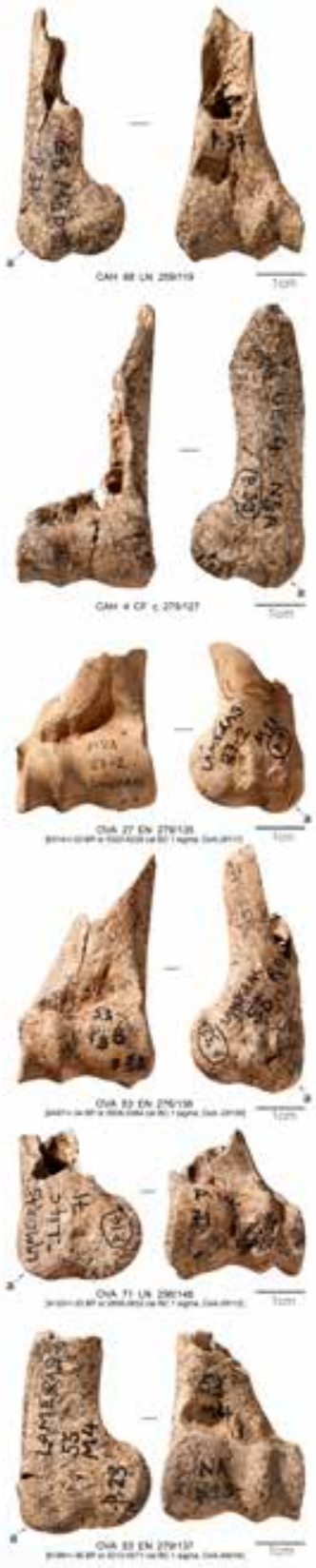

FIGURE 10

Distal fragments of six caprine humeri from Lameiras shown in anterior and medial view. Two are identified via Boessneck's (1969) criteria as goats (CAH) and four as sheep (OVA). Note the epitrochlea, labelled 'a', which tends to form a right angle in the sheep but is oblique in the goat. Identification is followed by the stratigraphic unit number in italics; date (EN - Early Neolithic, LN - Late Neolithic and CF - Late Chalcolithic); and measurements, in tenths of a millimetre, given as BT/HTC. The four sheep humeri from UE 27, 53, 71 and 53 have been radiocarbon dated (see text) and the results are also indicated here. 

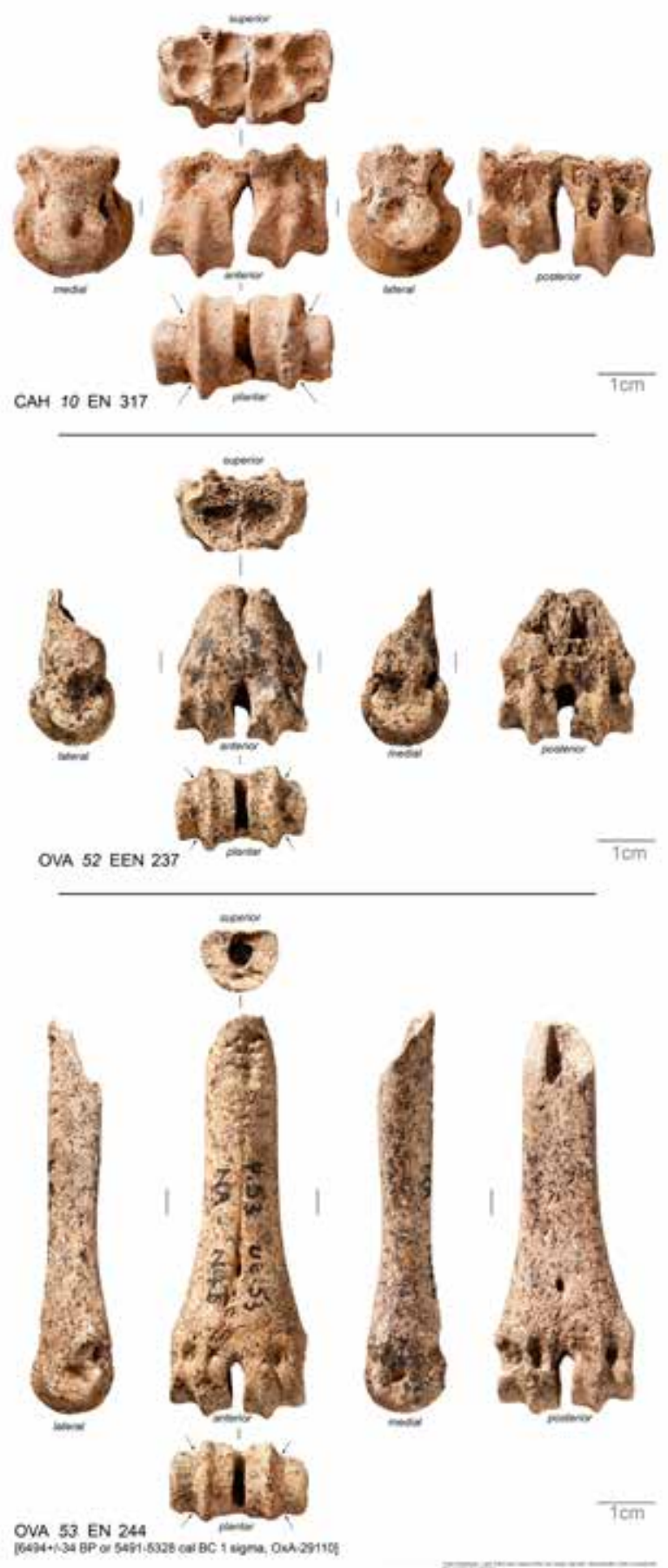

FIGURE 11

Distal metacarpals of a young goat (CAH) and two adult sheep (OVA) from Lameiras shown from all six sides - lateral, plantar, anterior, superior, medial and posterior. Note the considerably more constricted trochleae of the goat metacarpal compared to the two of sheep - the basis of Payne's (1969) metrical method for distinguishing metacarpals of these two taxa. Identification of each metacarpal is followed by the stratigraphic unit number in italics; date (EN - Early Neolithic, EEN - Evolved Early Neolithic); and BFd in tenths of a millimetre. The sheep metacarpal from UE 53 has been radiocarbon dated to 5491-5328 cal BC (1б, OxA-29110). 

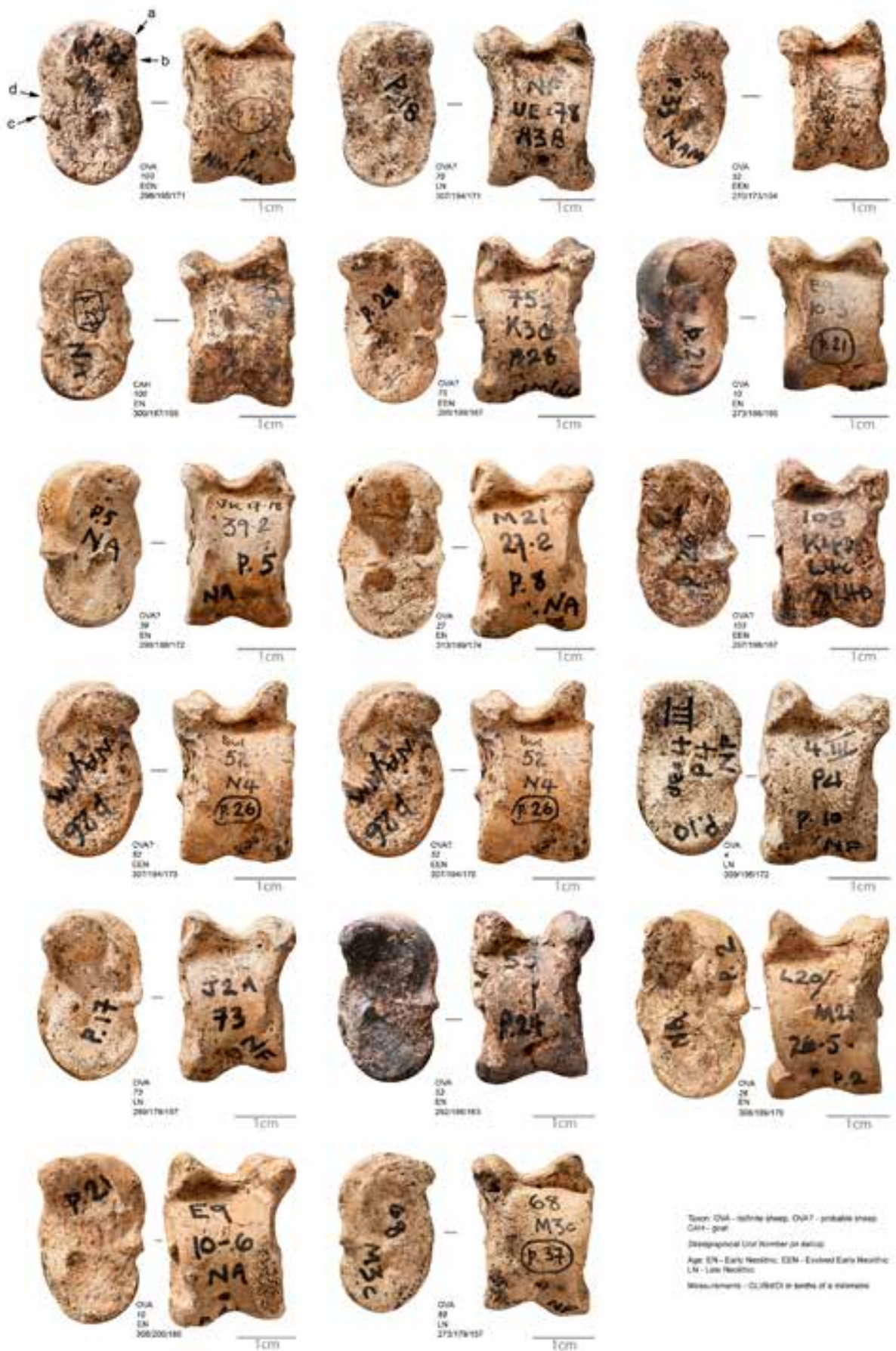

FIGURE 12

Sheep and goat astragali from Lameiras shown in medial and plantar views. Most are identified via Boessneck's (1969) criteria as sheep. Note these have a pronounced and wide projecting lobe on the plantar edge of the medial face (Boessneck's 'a') and a relatively reduced 'spine' in the centre on the dorsal side (Boessneck's 'c'). Astragali are identified as definite sheep OVA; probable sheep OVA? and a single goat $\mathrm{CAH}$ (several other astragali identified as goat are damaged). The stratigraphic unit number is given in italics and date as EN Early Neolithic; EEN Evolved Early Neolithic; and LN Late Neolithic. The measurements in tenths of a millimetre of each astragalus are given as $\mathrm{GL1} / \mathrm{Bd} / \mathrm{Dl}$. 
this difference that forms the basis of the metrical separation between sheep and goat metacarpals described by Payne (1969).

Astragalus. Figure 12 shows 17 of the better preserved caprine astragali from Lameiras. Each one is shown in medial and plantar views. Boessneck et al. (1964) and Boessneck (1969) described several characters on the astragali that help to distinguish between sheep and goat. These are labelled ' $a$ ' - ' $d$ ' on the top left specimen in this figure and as in Boessneck (1969: figure 64 and 65). Perhaps the most distinguishing feature is the projecting lobe ' $a$ '. This is the projection at the proximo-plantar angle of the medial articular ridge of the trochlea. It is more strongly developed in the sheep where it is rather wide and blunt, but in goat it tends to be more pointed. And the adjacent indentation ' $b$ ' is generally less pronounced in sheep. The dorsally projecting "cusp" 'c' on the medio-dorsal ridge tends to be more pronounced in goat than in sheep. Another character, perhaps more variable and therefore less trustworthy, is the crest on the medial side of the plantar surface which generally, though not always, remains parallel to the lateral side in goat and curves 'inwards' - i.e., towards the lateral side (or centre) of the astragalus in sheep.

Terminal phalanx. Figure 13 shows six caprine and two cervid terminal phalanges. The latter are, characteristically for the cervids, lacking an extensor process labelled 'ep' on the sheep phalanx from UE 91. Caprine terminal phalanges, unless very well preserved, can be difficult to identify to species. In lateral view the goat terminal phalanx tends to be rectangular in outline while that of the sheep more closely resembles a tri-angle. Moreover the distal part of the phalanx can be very thin and wafer-like in the goat but is thicker in the sheep. Of the six better preserved caprine specimens from Lameiras shown here, one is definitely goat, one is probably goat, one is definitely sheep, and two are almost certainly sheep and the other is of uncertain identity but perhaps more likely to have belonged to a sheep.

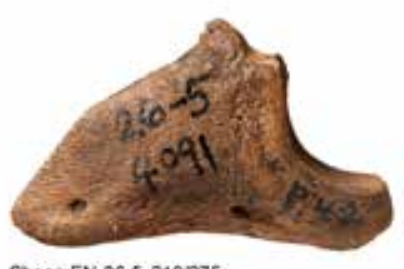

Sheep EN $26-5219 / 275$

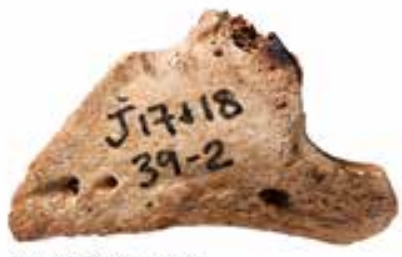

Sheep? EN $29-2-275$

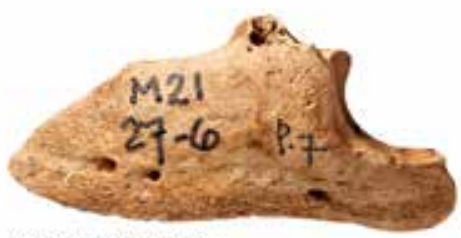

Sheep? EN 27 260/323

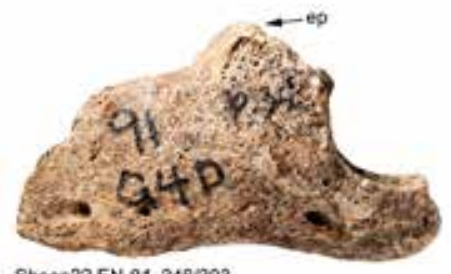

Sheeg? EN 91 248/303

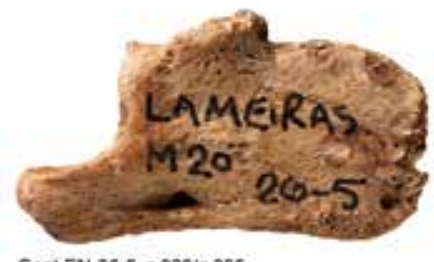

Goat EN $26-5$ < $2201<295$

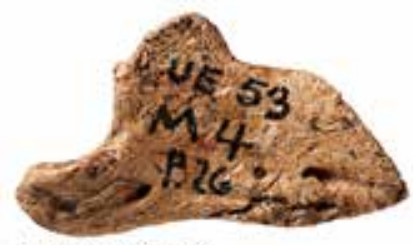

Goat? EN 53 2291280

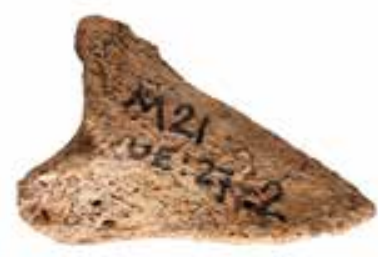

Roe deer EN 27-2 2507253

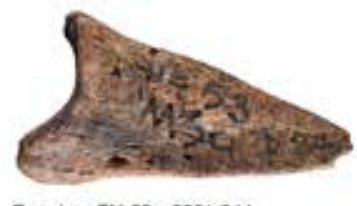

Roe deer EN $53>228 / 244$

FIGURE 13

Eight terminal phalanges of sheep, goat and roe deer from Lameiras in external view. All come from the Early Neolithic (EN). The measurements Ld (length of the dorsal surface) and DLS (greatest, diagonal, length of the plantar surface) are given in tenths of a millimetre. The majority of the caprine terminal phalanges are identified as sheep or probable sheep and there is one definite and one probable goat. Note the two on the right which, like all cervids, lack an extensor process and are identified as roe deer. 


\section{METRICAL METHODS TO DISTINGUISH SHEEP BONES FROM GOAT BONES}

Measurements taken on two bones, the distal metacarpal and the astragalus can be used to separate sheep from goat [Payne (1969) for the metacarpal; Davis $(2016,2017)$ for the astragalus]. These metrical methods should not be used alone to make the distinctions but rather used as an aid to corroborate those made on the basis of morphology. At Lameiras, we see an interesting difference in the sheep: goat ratio between the distal metacarpal and the astragalus. Thus Figure 14 [which shows the method described by Payne (1969)] for the metacarpal condyles indicates an approximately equal proportion of sheep and goat. Another metrical method has recently been described by one of us (Davis, 2016, 2017). This utilises the small shape difference between sheep and goat astragali. Instead of plotting simple measurements on a scatter diagram, two indexes are plotted, one is the lateral depth (Dl) divided by the greatest lateral length (GLl) and the other index is the distal width (Bd)

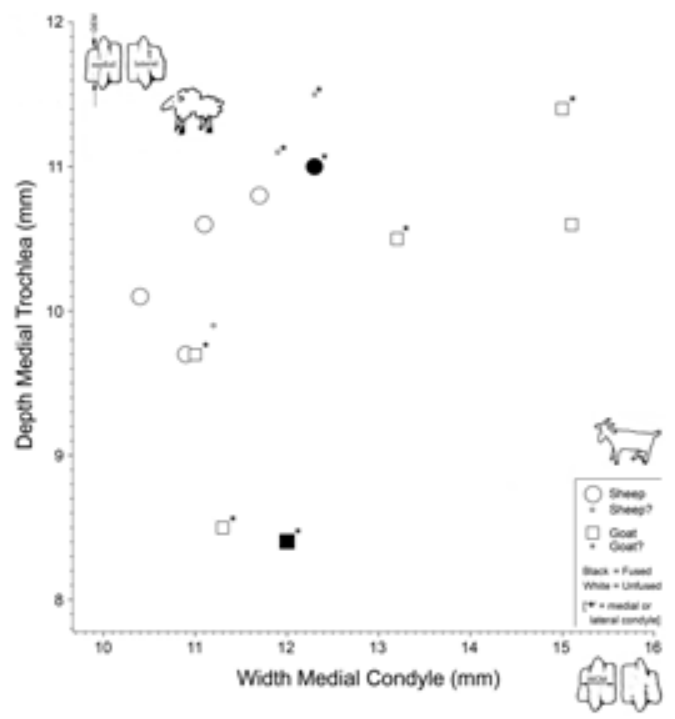

FIGURE 14

Metrical separation of sheep from goat metacarpals at Lameiras (following Payne, 1969). Specimens identified morphologically as certain goat or certain sheep are represented by large squares and circles respectively, while those less securely identified are shown as small symbols. Symbols with an asterisk represent condyles whose position - medial or lateral - was uncertain due to their being isolated from their respective adjacent condyle. Black symbols represent adult (epiphysis fused) specimens and white symbols represent juvenile (epiphysis unfused) ones. divided by the lateral depth (see Figure 15). With the first index plotted on the vertical axis and the second on the horizontal axis, modern sheep tend to plot out in the top left hand side while goats are below and/or to the right. The distribution of the scatters is more distinct in Cyprus and less so elsewhere and so does not provide a certain method. This figure indicates many more sheep than goat at Lameiras.

In sum. Let us consider the sheep and goat teeth and bones separately (see Tables 1 to 7 ). While the overall picture at Lameiras appears to indicate more sheep than goats, when one examines the counts for individual parts of the skeleton the sheep: goat ratio varies between $15 \%$ goats (metatarsals), to $40 \%$ goats (metacarpals). The large variation in the sheep: goat ratio is partly due to the smallness of the samples as well as perhaps SJMD's varying ability to distinguish between sheep and goat bones!

\section{Ovis - sheep}

Having determined the presence of both Ovis and Capra at Lameiras, we need to ask what their wild/domestic status was and to what extent they are similar or different from their relatives in earlier or later times. In the case of the Ovis, there can be no doubt that the sudden arrival of this exotic animal in Portugal must signify its domestic status. It can only have been brought here by people. The sheep from Lameiras are therefore among the oldest examples that we have from Portugal. How do they compare with sheep from later periods? Figure 16 shows stacked histograms of the lengths and widths of sheep astragali from different sites in southern Portugal [adapted and updated from figures 8 and 9 in Davis (2008)]. Although the sample-sizes are small, there is some indication that these early sheep were slightly larger than their descendants in Chalcolithic and Iron Age Portugal but little different in size from modern wild Ovis orientalis from the Near East (in the Field Museum, Chicago) - a pattern which is also clear in Figure 17. Were these new arrivals in Lameiras, being more closely related to recently domesticated sheep in the Near East, still quite large like their wild ancestors? Plotting astragalus size, GLl, versus shape, $\mathrm{Bd} / \mathrm{Dl}$, as in figure 4 of Davis (2008) 


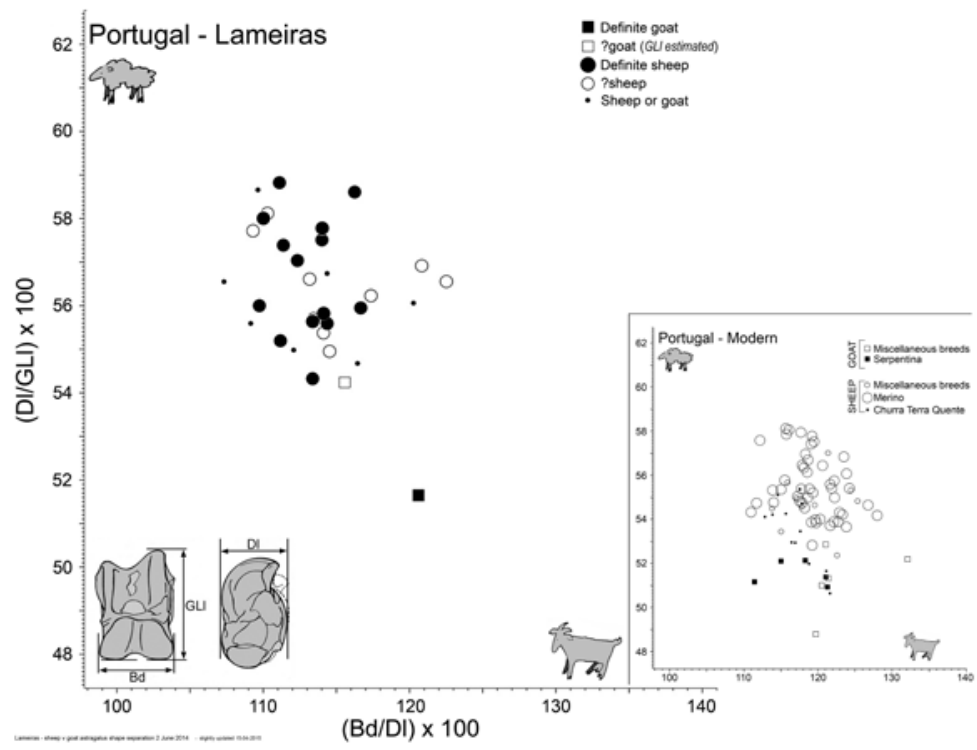

FIGURE 15

Metrical separation of sheep from goat astragali at Lameiras (following Davis, 2016, 2017) using the three measurements commonly taken on artiodactyl astragali. A plot of $\mathrm{Dl} / \mathrm{GLl}$ versus $\mathrm{Bd} / \mathrm{Dl}$ for the 32 caprine astragali identified via the morphological criteria described in Boessneck (1969). Specimens identified morphologically as goat or sheep are represented by black squares and circles respectively, while those less securely identified are shown as white symbols. Seven could not be identified to species and are shown as small black dots. There is, on the basis of modern specimens from Portugal (see insert for modern Portuguese caprines of known identity) and other countries, a guesstimated 10 - 15\% overlap which means that an individual specimen cannot be identified with certainty. On the basis of this metrical method sheep appear to far outnumber goats.

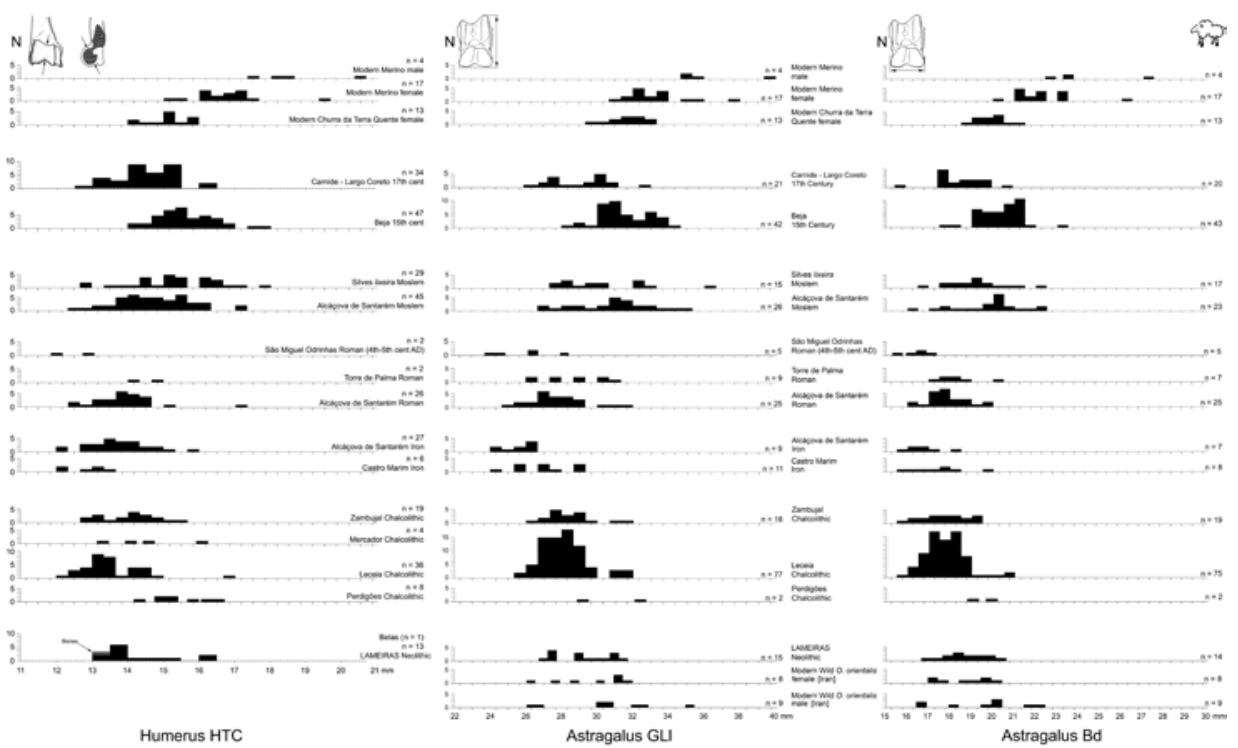

FIGURE 16

Neolithic to present day changes in the size of Portuguese sheep. These are stacked histograms of measurements of the humerus minimum trochlea diameter (HTC), astragalus greatest lateral lengths (GLl) and astragalus distal widths (Bd). The Lameiras Neolithic sheep are slightly larger than those from the Chalcolithic, Iron Age and Roman periods. This is difficult to explain but could reflect a post-Neolithic decline of agricultural practises in Portugal. It is not until the Moslem period that we see an increase in size - presumably reflecting improvement. This figure is adapted from figures 6,8 and 9 in Davis (2008). For the astragalus measurements, below are 17 modern wild sheep from Iran - the area where this animal was first domesticated (specimens in the Field Museum of Natural History, Chicago, measured by Rebecca Banasiak). Note that they are on average similar in size to the Neolithic sheep from Lameiras. 
and shown here as Figure 17, we can see that the sheep astragali from Lameiras overlap, in terms of shape and size, with those from the Chalcolithic - somewhat slender and probably long-limbed. These are inferences we can perhaps make on the basis of the correlations of the different astragalus measurements and general skeleton conformation (Davis, 1996). This graph suggests that in terms of their shape the Neolithic and Chalcolithic Portuguese sheep as well as the modern wild sheep were/are relatively slender-limbed. Iron Age to modern Portuguese sheep were/are more robust with shorter limbs. In terms of size it is probable that sheep in Portugal became considerably smaller by Iron Age times and then increased in size, especially in the Medieval-Moslem period. Much caution is needed in making these interpretations from Figure 17, in part because many of these samples are small and as the modern Shetland sheep of known sex indicate, differences in the sex ratios of these samples could 'cause' a difference in the shape of the astragalus [although Popkin et al. (2012) did not find much variation

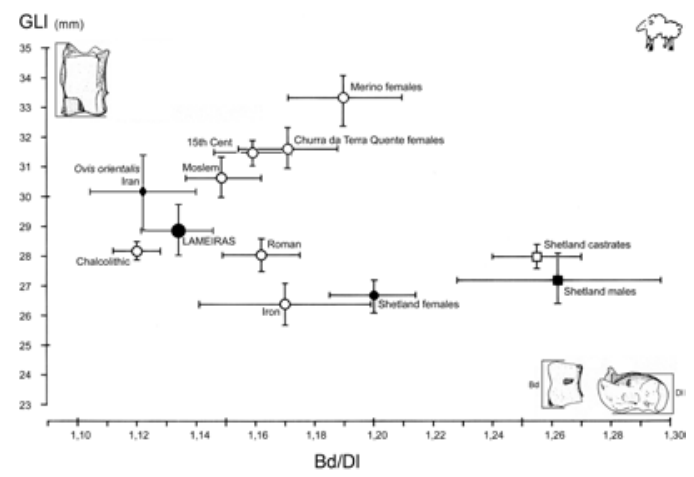

FIGURE 17

Variation in size and shape of archaeological sheep from Portugal alongside various modern sheep - wild from Iran, unimproved Shetland (Davis, 2000), Churra da Terra Quente and Merinos (based upon figure 4 in Davis, 2008). Summary diagrams of astragalus $\mathrm{GLl}$ (size) versus astragalus $\mathrm{Bd} / \mathrm{Dl}$ (shape), the graphics show mean values \pm their $95 \%$ confidence limits. The Lameiras specimens are most similar to the Chalcolithic sheep as well as modern wild sheep from Iran (in the Field Museum, Chicago). Given the way astragalus measurements are correlated with body proportions (Davis, 1996); astragali plotting to the left probably belonged to slender long-limbed animals, while those to the right are probably from robust, short-limbed animals. Note the increase in robustness from wild, Neolithic and Chalcolithic to modern domestic and the increased size of the Moslem period Portuguese sheep compared to their Neolithic - Roman ancestors. Note also the small, but statistically significant size difference between Iron Age and Roman times. Did the Romans improve sheep in Portugal if in only a small way? with sex of the index $\mathrm{Bd} / \mathrm{Dl}$ in their much larger sample of Shetland sheep]. Size and shape variation of sheep bones through time may prove to be a worthwhile avenue for further study.

\section{Capra-goat}

As already mentioned, a wild Capra (the Spanish Ibex) existed and still exists in the Iberian Peninsula. According to personal observations (SJMD) it is not possible morphologically to distinguish bones of this wild animal from those of the domestic goat, although horn cores may be an exception. Can size help? Figure 18 shows stacked histograms of the distal widths (Bd) of Capra astragali from different periods in Portugal alongside, for comparative purposes, modern wild goats from the Near East (the probable origin of our domestic goat), wild Capra pyrenaica from Jaén province, Andalucía, in Spain and a collection of feral domestic goats from the island of Mallorca. Variations of these different populations of goat may be explained in terms of a) climate, b) wild-domesticated status and perhaps also c) the effect of human improvement of domestic goats. First, note the very large size of the late Pleistocene Capra, presumed wild goats, from Caldeirão cave (Mousterian, Solutrean and EUP); Lapa dos Coelhos (Solutrean and Magdalenian) and Mousterian Oliveira cave (currently being studied by Mariana Nabais). These are quite clearly set apart from all the other samples of Capra and are even larger than the modern wild ibex (Capra pyrenaica hispanica) from Jaén, shown at the top. It is interesting too; that modern wild goats, Capra aegagrus, from the Near East are intermediate in size between the Pleistocene form and Neolithic to Roman goats. Note that the Neolithic - Roman goats were all somewhat smaller than those from the Medieval-Moslem - modern domestic goats. This Roman to Medieval-Moslem size increase of Portuguese Capra probably reflects an improvement of goats by the Moslems as was suggested for the sheep (Davis, 2008).

Like several mammalian taxa in the Near East (Davis, 1981), Portuguese Capra underwent a reduction in size on two occasions. The first happened at the end of the Pleistocene when temperatures rose and the second happened in association with the domestication of this animal. Then, per- 


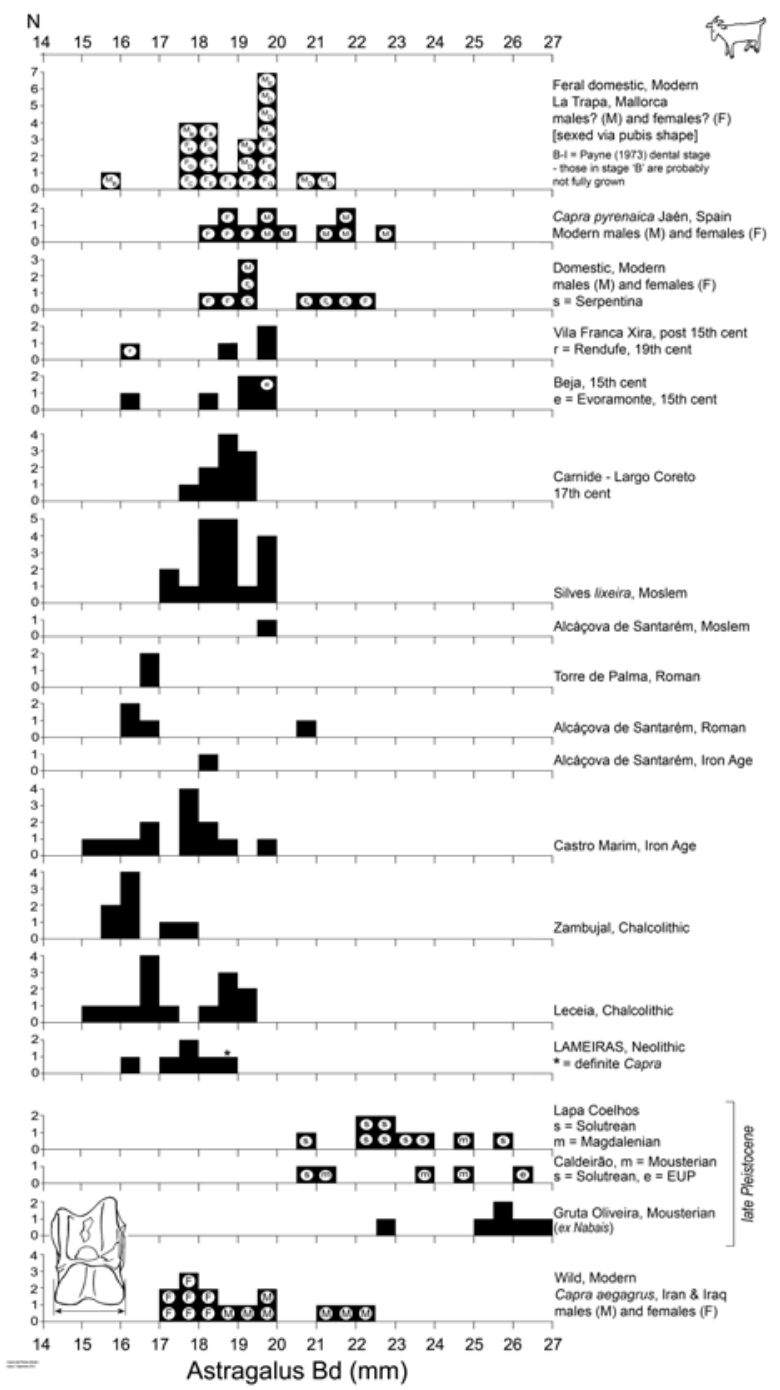

FIGURE 18

Stacked histograms of distal widths of Capra (goat) astragali showing variation of size from late Pleistocene to modern times. This figure shows probable environmental and cultural influences. The top two histograms are 1) modern feral goats from Mallorca collected by Alex Valenzuela, sexed via the shape of their pubes and aged via their tooth eruption and wear (as in Payne, 1973) and 2) modern Spanish Ibex from Jaén province in the Natural History Museum of Madrid, of known sex; nine adults and two sub-adults. At the bottom are modern wild goats from Iran and Iraq - the region where goats were probably first domesticated (these are in the Field Museum of Natural History, Chicago and were measured by Rebecca Banasiak). Note that 5 of the 6 Capra astragali from Lameiras are damaged - their identity could not be metrically corroborated - they are probably but not certainly goat. This chronological sequence with the modern specimens indicates five size-groups:

- $\quad$ Late Pleistocene wild Capra from Oliveira cave (studied by Nabais), Caldeirão cave (Davis, 2002) and Lapa dos Coelhos near Torres Novas (Davis, unpublished) - the largest; presumably adapted to the colder conditions as predicted by Bergmann's (1847) rule.

- Modern wild Capra from southern Spain - smaller than the Pleistocene Capra from the three Portuguese sites. Note that they are, on average, slightly larger than Portuguese Neolithic - Roman domestic goats.

- $\quad$ Neolithic (Lameiras), Chalcolithic, Iron Age and Roman Capra - all smaller than wild Capra.

- Moslem period to 19th century Capra - slightly larger than the Neolithic-Roman ones and presumably, like the sheep, improved. Note too that the modern domesticated goats (these include five Serpentinas) are on average somewhat larger still, presumably reflecting recent improvements.

- The modern wild goats from Iran and Iraq as well as the feral goats from Mallorca are probably, on average, very slightly larger than the Neolithic - post-15th century goats from Portugal.

The Lameiras Capra astragali are smaller than wild and feral goats and similar in size to Chalcolithic to Roman goats. They most probably belonged to domesticated animals. 
haps when the Moslems ruled southern Portugal, goats underwent a small size increase. This means that Capra bones can be assigned to one of four different size groups in the course of time (i.e., modern wild, late Pleistocene (presumed wild), Neolithic-Roman domestic and Moslem to modern times domestic). Maria Saña [personal communication and Saña (2013: figure 10.13)] is finding some of these same size changes in Capra in Catalonia where the Palaeolithic $C$. pyrenaica were larger than their descendants in the Holocene, while Capra bones from the Early Neolithic at La Draga, near lake Banyoles, are very considerably smaller.

It is clear from these stacked histograms that the Lameiras Capra astragali are very similar in size to those from Chalcolithic, Iron Age and Roman sites. They are smaller than those of modern ibex. In the light of the size differences between, on the one hand, the modern ibex and late Pleistocene Capra and, on the other hand, the Capra from Chalcolithic, Iron Age and Roman periods, it is concluded that the Lameiras Capra were domestic.

\section{Equus - horse etc.}

Equids, especially the horse, as well as red deer and some ibex, aurochsen and wild boar were probably the main sources of meat for people in late Pleistocene Portugal. This seems to have been the case at Mousterian Lameiras. However, by the time of the Neolithic as indicated by the species counts at Lameiras, equids, like red deer, had become very scarce. But which species of equids can we identify? The dental enamel patterns on the occlusal surface of the lower cheek teeth, all from the Mousterian, clearly indicate the presence of the horse - with its characteristic ' $U$ ' shaped lingual fold and partial penetration between the flexids of the buccal fold in the molars (Figure 19). Figure 20 shows, in anterior view, two equid metapodials from the Chalcolithic at Lameiras. They are so different in size that they cannot have belonged to the same species. The larger is most likely a horse - an identification now supported by its DNA (Bennet \& Geigl, pers. comm.) - while the smaller is similar in size to the so-called

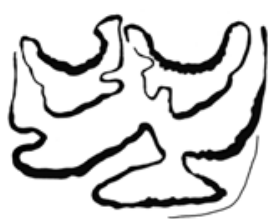

TPM UE: 130
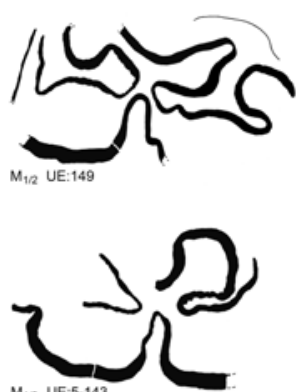

$M_{12}$ UE-5-143

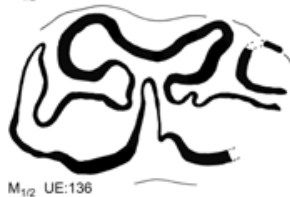

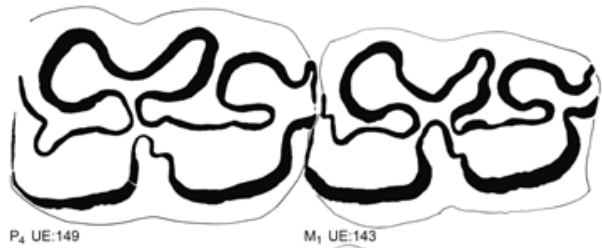
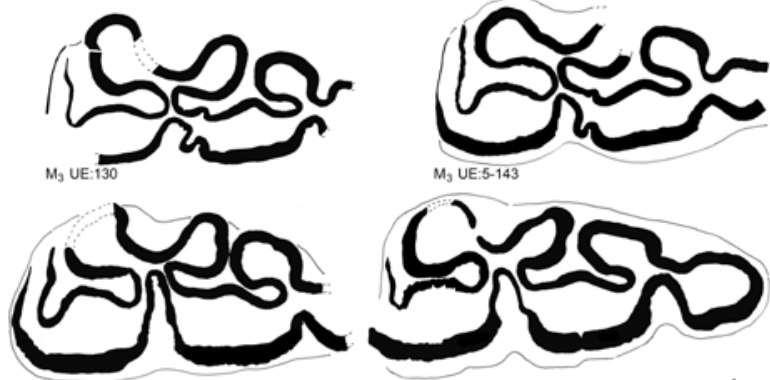

$M_{3}$ UE:5

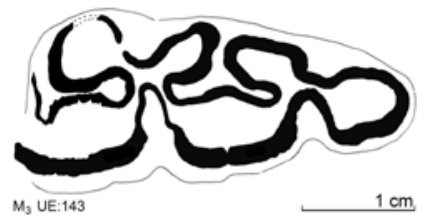

FIGURE 19

One upper and nine lower equid cheek teeth from Mousterian Lameiras in occlusal view showing their enamel folds in black. The lower fourth premolar (UE 149) and lower first molar (UE 143) adjoin. All other teeth are isolated. The single, and rather abraded, upper tooth, probably a premolar, has an elongated protocone - characteristic of the horse. In the lower teeth note the ' $U$ ' shaped internal fold - another horse feature. The tendency for the external fold to partly penetrate between the flexids in the molars but not the premolars is another horse character and is observed here in most but not all the molars. The two that do not show this (UE 130 and UE 5-143) are from young adults. Generally this penetration only becomes clear further down the crown, i.e., in older animals. Indeed the third molar from UE 130 viewed from below shows clear partial penetration of the external fold. The scale is $1 \mathrm{~cm}$. 
Otranto ass - Equus hydruntinus - first described by Regalia (1907) [see also Stehlin \& Graziosi (1935)] from a cave in Apulia, Italy and sadly now extinct. E. hydruntinus has dental characters that are very similar to those of the African zebras (Eisenmann, 1981) but the genetic evidence indicates that it may have been a European sub-species of the Asiatic half ass (Orlando et al., 2006). Unfortunately there are no equid teeth in any of the levels at Lameiras that in any way resemble those of E. hydruntinus. Indeed the only possible candidate bone for this species of small equid is the small metapodial shown in Figure 20.

\section{Cervus - red deer}

This animal, along with the horse, was probably the mainstay of peoples' diet in late Pleistocene Portugal. However, very few remains at Lameiras belonged to red deer. They include a single tooth and a distal humerus from the Mousterian and a distal tibia from the Late Neolithic. With so few red deer bones found at Lameiras it is not possible to study how their size compares with the red deer of earlier and later periods.
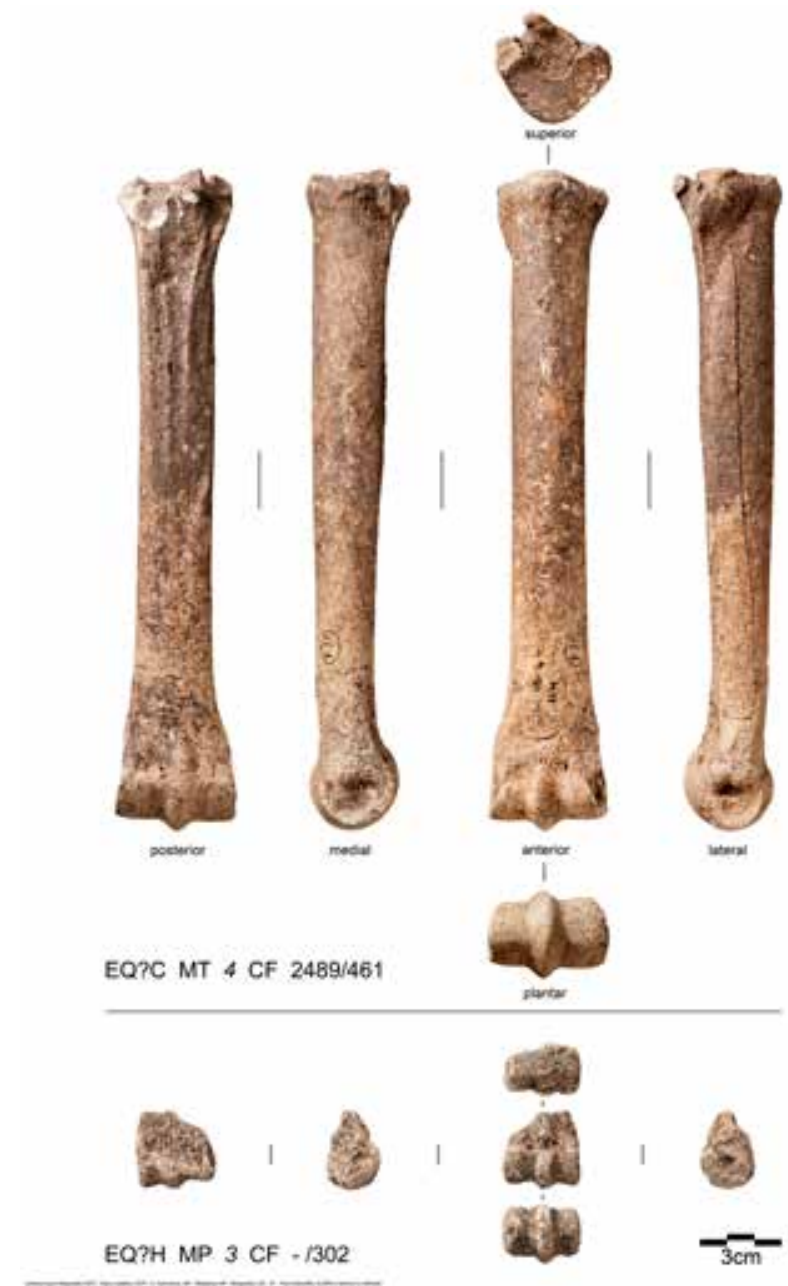

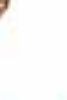

FIGURE 20

Two equid metapodials, one complete and one a distal fragment, from the late Chalcolithic of Lameiras shown from all four sides - posterior, medial, anterior, lateral - as well as superior and plantar views. The complete metatarsal (from UE 4) is identified both morphologically and via its ancient DNA (Eva-Maria Geigl, pers. com.) as horse, Equus caballus. The small distal metapodial fragment (from UE 3 ) may have belonged to the small, now extinct, equid, E. hydruntinus. The measurements in tenths of a millimetre of each metapodial are given as follows - GLl (greatest length)/BFd (width across the distal articulation). 


\section{Capreolus capreolus - roe deer}

The Lameiras fauna includes several bones of this small species of cervid. For example the base of an antler from the Early Neolithic (shown in Figure 21) clearly belonged to a roe deer, as did two terminal phalanges (shown on the right-hand side of Figure 13), both lacking an extensor process, and also dated to the Early Neolithic. A roe deer distal humerus was also identified in the Late Neolithic. The roe deer is a woodland animal so its presence indicates the probable existence of woodland in the neighbourhood of Lameiras in Neolithic times, although given the finds of domesticated cereals (López-Dóriga \& Simões, 2015) some of the surrounding countryside must have included arable land too.

\section{Sus - wild boar/pig}

The wild boar - ancestor of the pig - was probably first domesticated in the Near East, although genetic evidence indicates a strong possibility that there were other independent centres of pig do- mestication (Larson et al., 2005; Albarella et al., 2006). Wild boar bones and teeth are usually larger than those of pig but for many measurements there is considerable overlap which makes it difficult and sometimes impossible, to identify a Sus bone as belonging to the wild or domestic form of Sus (Payne \& Bull, 1988). The wild-domestic distinction is even more difficult to make here in the Iberian Peninsula where the wild boars are rather small. In our study (Albarella et al., 2005) of Holocene Sus from Portugal, we found that at many sites, especially Chalcolithic Zambujal, most Sus bones and teeth formed a cluster while there were a few larger specimens. Like Driesch \& Boessneck (1976) in their original study of the Zambujal bones, we also interpreted the small ones as having belonged to domesticated Sus (i.e., pig) and the few large specimens as wild boar. By applying this reasoning and assuming our interpretation was correct we can see that the plots for Sus bones from the Neolithic of Lameiras (Figures 22 and 23) are all similar to the smaller cluster at Zambujal. This is especially the case for the distal tibia widths. But note that for the measurement humerus HTC it is not possible to rule out the possibility that one or two of the larger specimens belonged to wild
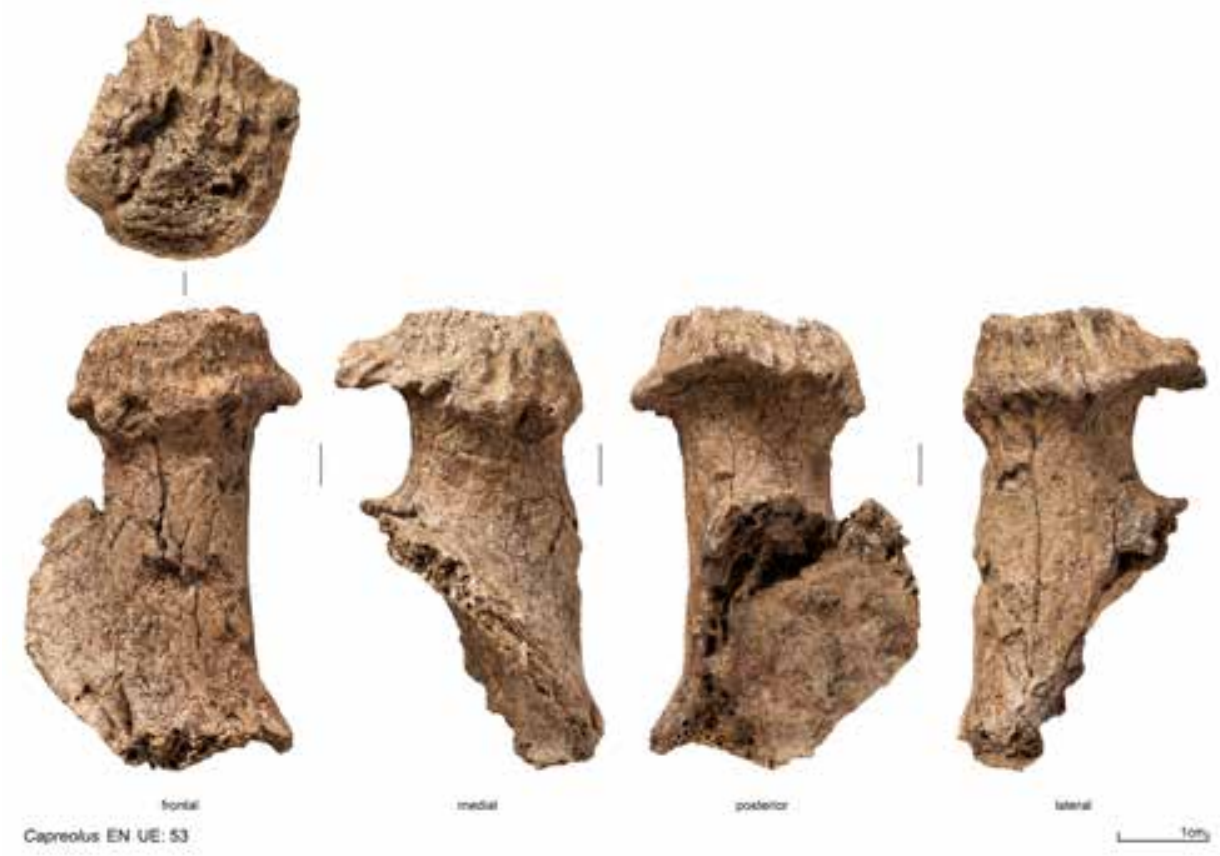

FIGURE 21

Five views of an Early Neolithic roe deer (Capreolus) antler fragment joined to the pedicle and part of the skull from UE 53. Since it was still joined to the skull it must have been killed between April and October. 

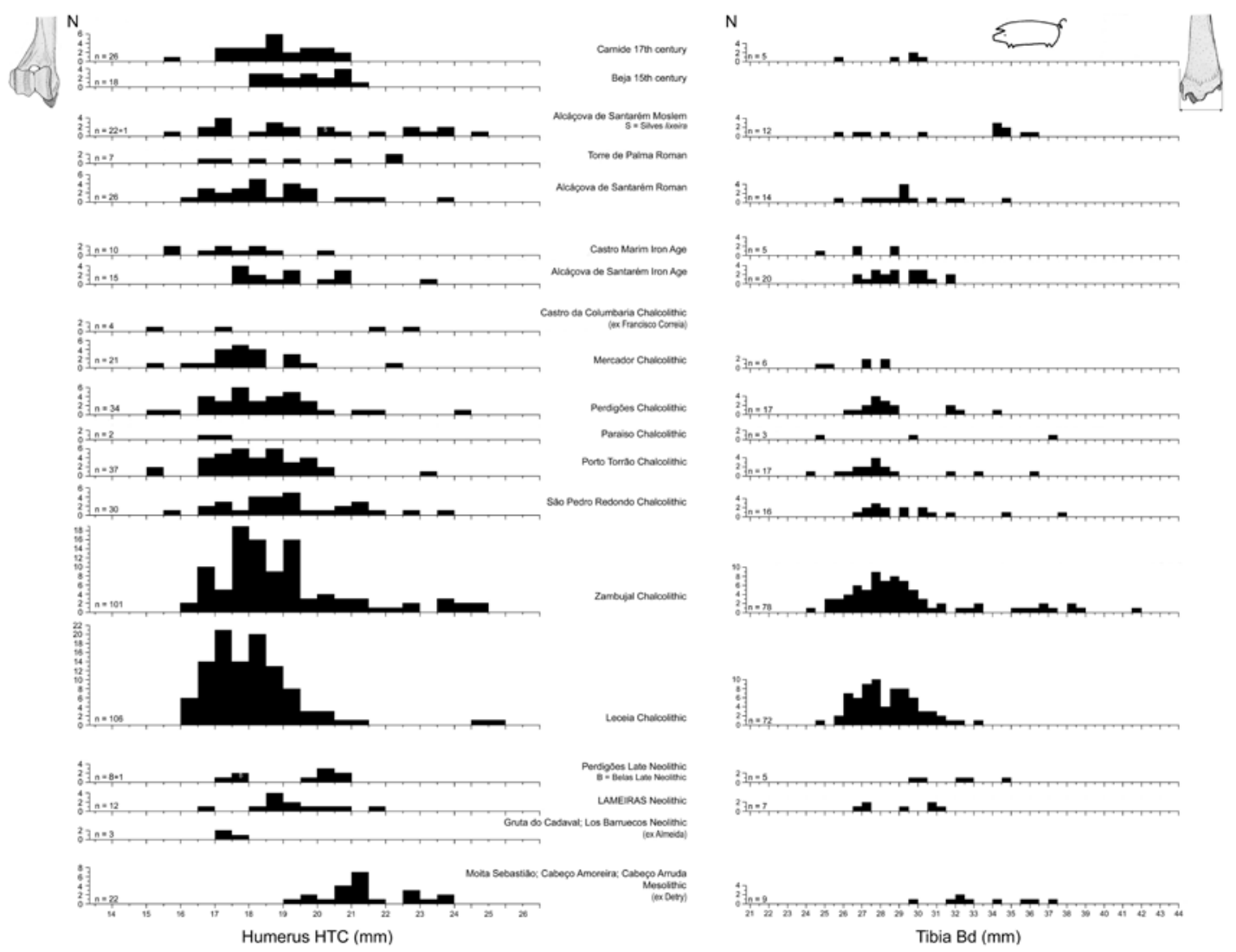

FIGURE 22

Mesolithic to Moslem period changes in the size of Portuguese Sus (wild boar and pig). Stacked histograms of the humerus minimum trochlea diameter (HTC) and tibia distal width (Bd) to show a) the metrical distinction between wild boar and pig and b) possible chronological size changes. While the wild boar and pig bones do not separate completely, wild boar tends to be somewhat larger - note especially the wild boar from Mesolithic Muge (Detry, 2007; see also Albarella et al., 2005). These plots show a few specimens at Zambujal that probably belonged to wild boar - humeri with $\mathrm{HTC}>$ c. $22 \mathrm{~mm}$ and tibiae with $\mathrm{Bd}>$ c. $35 \mathrm{~mm}$. It is unknown to what extent measurements of wild boar and pig overlap. The Neolithic Lameiras Sus are small and therefore presumably pig. The apparent greater proportion of wild boar in the Moslem period at Alcáçova de Santarém may reflect the more relaxed attitude of Maghrebi Islam towards consumption of wild boar compared to pig which is strictly harram (see Albarella et al., 2005). It is also worth noting that the wild boar bones of Muge are smaller than the presumed wild boar at Zambujal and the few various larger specimens from later sites. This indicates that, like aurochs and possibly red deer, this animal had become unusually small in the Mesolithic, perhaps due to overhunting (see Davis \& Detry, 2013).

boar. We conclude that the majority, possibly all, the Sus bones, both in the Early and Late Neolithic, belonged to pig. Another point worth noting in this figure is the apparent size increase of the presumed wild boar after the Mesolithic in a manner reminiscent of what happened to the aurochsen in southern Portugal (see above). In other words the Mesolithic wild boar was exceptionally small and recovered some of its former size after the Mesolithic. The exceptionally small size in the Mesolithic may reflect overhunting at that time when there was what we called a 'crisis' due to overpop- ulation and hence over-hunting of the larger terrestrial mammals (Davis \& Detry, 2013). Figure 24 shows the greatest lateral lengths of the Lameiras Sus astragali alongside wild boar from Mesolithic to $17^{\text {th }}$ century sites in southern Portugal. Most of the Lameiras Sus appear to have belonged to pig while some may be wild boar. If so, note again that the small peak of specimens representing wild boar at Zambujal are larger than the Mesolithic ones and the larger specimens from Lameiras - if these were really wild boar. 


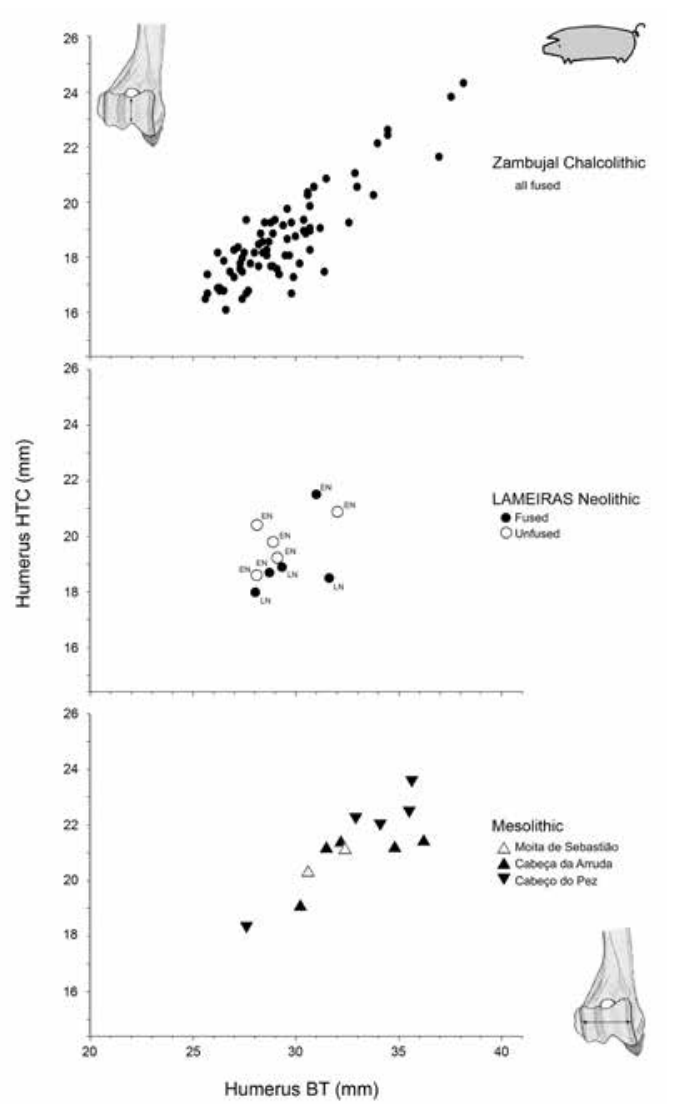

FIGURE 23

Sus humerus trochlea width (BT) versus minimum diameter (HTC) - Lameiras compared to Mesolithic sites (data from Cleia Detry) and Zambujal (Chalcolithic). Note the overall larger size of the Mesolithic specimens and the few even larger ones from Zambujal that plot in the top right (see also Figure 22 and Albarella et al., 2005). The relatively small size of the Mesolithic wild boar compared to the supposed wild boar at Chalcolithic Zambujal is again visible here as in Figure 22. At Zambujal most Sus humeri are smaller and are assumed to have belonged to pigs. All the Neolithic specimens from Lameiras (EN - Early Neolithic and LN - Late Neolithic) are smaller and are therefore presumably domestic.

\section{Canis - wolf/dog}

Generally dog teeth and bones are smaller than those of their ancestor the wolf, Canis lupus, although, as with aurochs and cattle, there is some overlap. Figure 25 shows the variation of size of the lower carnassial tooth, $\mathrm{M}_{1}$, of modern wolves and dogs from Portugal and specimens of Canis $\mathrm{M}_{1}$ from various archaeological sites including Lameiras. The two specimens from Mesolithic Muge (Detry \& Cardoso, 2010) and a recently discovered
Canis burial from Mesolithic Poças de São Bento in the Sado estuary are all small and more likely to have belonged to dogs than wolves. The two Neolithic carnassials from Lameiras (UE 68, Late Neolithic and also shown in the inserted image; whose crown length is 20,7 and width 7,7 mm) and Belas (crown length 20,0 and width 7,7 mm) are of similar small size, and most probably also belonged to dogs rather than to wolves.

\section{Felis silvestris - cat}

Nine bones and a tooth fragment of small cat were identified - all in the Early Neolithic. One, a radius, has small cut marks across its distal end. These were probably inflicted while processing the carcass for consumption and/or its skin.

\section{Lagomorphs - rabbit and hare}

Both rabbit and hare are represented at Lameiras with rabbit bones far outnumbering those of hare. Bones of these two taxa are morphologically rather similar but are usually fairly easily distinguished on the basis of their differing size - hares being distinctly larger [see figures 10 and 11 in Davis et al. (2008)]. Thus note (Appendix A) the two Neolithic hare humeri whose widths $(\mathrm{Bd})$ are 10,6 and 11,0 $\mathrm{mm}$ and minimum diameter of the trochlea (HTC) are 5,7 in both specimens. These measurements for the Neolithic rabbits range between 7,7 - 8,9 and 3,4 - 4,2 $\mathrm{mm}$ respectively. In the Mousterian note a tibia with $\mathrm{Bd} 12,1 \mathrm{~mm}$, and a humerus with HTC 4,5 mm. These are large which is not surprising given the larger size of late Pleistocene rabbits as noted at Caldeirão cave (Davis \& Moreno-García, 2007: 54-59).

\section{Other taxa}

A number of bones and teeth of small mammals were found. To what extent they related to the human occupants is unknown and some may simply be intrusive. Thus the Early Neolithic layers included three mandibles of wild mouse (Apodemus), a mandible of the water vole (Arvicola sapidus), two fragments of hedgehog (Erinaceus) 

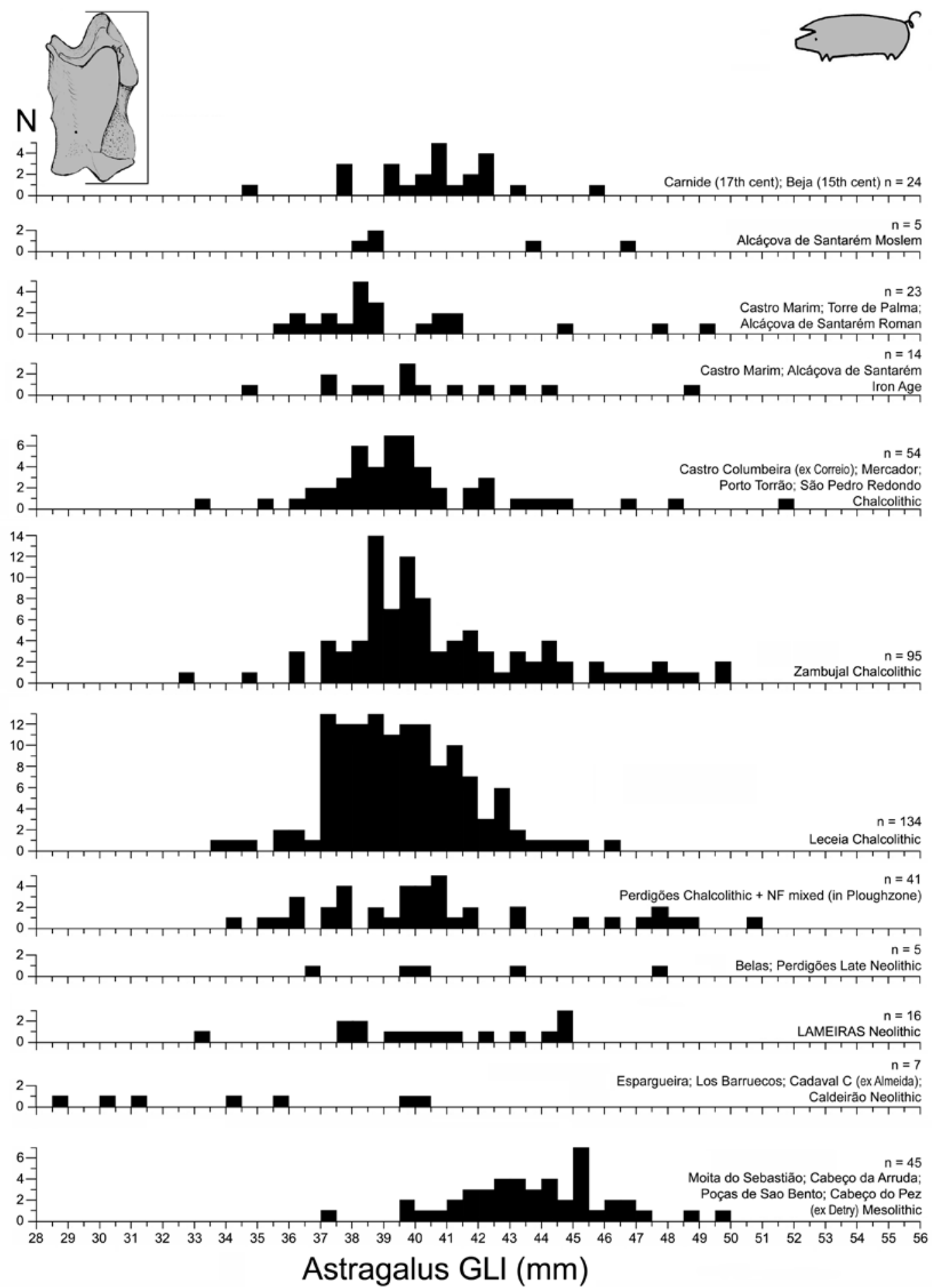

FIGURE 24

Stacked histograms of Sus astragalus greatest lateral length (GLl) - Lameiras compared to other sites in Portugal and adjacent parts of Spain. The Lameiras Neolithic astragali are small and hence also presumably domestic, although it is possible that some of the larger ones belonged to wild boar. Date for several sites kindly supplied by colleagues - whose names are inserted in parentheses. 


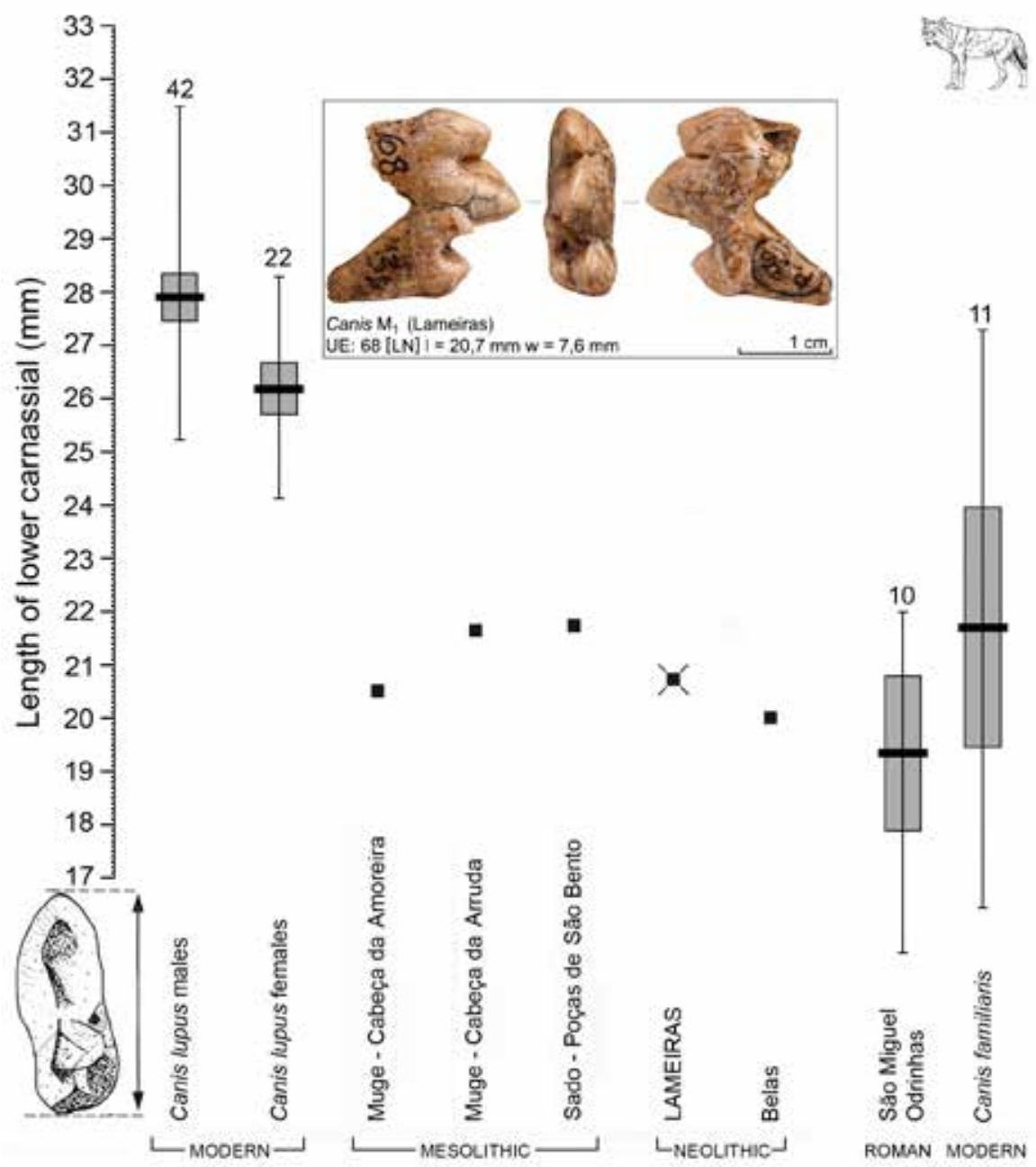

FIGURE 25

The first lower molar (carnassial tooth; $\mathrm{M}_{1}$ ) of a Late Neolithic Canis from UE 68 shown in the inset photograph in lingual, occlusal and buccal views. This tooth is plotted alongside modern Portuguese wolf carnassials, Canis (probably dog) from Mesolithic and Neolithic sites in Portugal, 10 Roman dogs from São Miguel Odrinhas near Sintra dated to the $4^{\text {th }}-5^{\text {th }}$ centuries AD and modern dogs. With its length of $20,7 \mathrm{~mm}$, the Lameiras $\mathbf{M}_{1}$ almost certainly belonged to a dog rather than wolf. Individual specimens are portrayed as small squares. For the four samples, the graphics show the mean as a horizontal black line and its $95 \%$ confidence limits enclosed within the grey box. The thin vertical line shows the range with sample size given at the top. Many measurements supplied by Cleia Detry.

and nine vole (Microtus) mandibles. In the Mousterian there were two mandibles of voles and 29 humeri of moles (Talpa). The mole humerus, with its particularly robust shape adapted for burrowing is unmistakeable and easily recognised.

Birds too are represented if scarcely. For example a proximal phalanx of the great bustard (Otis tarda) was identified in the EEN, a bone of a hawk (Accipiter) in the EN and two bones of partridge (Alectoris) in the Chalcolithic.
Amphibia and reptiles were also found in all the levels. For example the Mousterian included eleven amphibian bones - probably all toads (Bufo). This taxon was also present in the EN $(\mathrm{n}=9)$ and $\mathrm{LN}(\mathrm{n}=3)$. Two carapace osteoderms of the pond turtle (Mauremys) were found in the EN, and two lizard (Lacerta) mandibles were found one in the $\mathrm{EN}$ and the other in the LN. 
Fish (Table 8 and Appendix C)

The fish remains include 53 vertebrae, 11 cranial bones, eight teeth, two fin spines and one otolith. Another five bones are fragments that could not be assigned to part of body. The identified fish bones belonged to marine species. The presence of a few burn marks and perforations indicate that humans were the main agents responsible for their accumulation.
The Early Neolithic fish assemblage

Fish remains are more frequent in the Early Neolithic collection and comprise 67 remains of which 62 were identified to family or higher taxonomic level. Their greater abundance in the EN is almost certainly due to the different recovery strategy used during excavation as mentioned above.

\begin{tabular}{|c|c|c|c|c|c|c|c|c|c|c|c|c|c|c|c|}
\hline & \multicolumn{4}{|c|}{$\mathbf{E N}$} & \multicolumn{4}{|c|}{ EEN } & \multicolumn{4}{|c|}{$\mathbf{L N}$} & \multirow{2}{*}{\begin{tabular}{|l|} 
GAP \\
NISP
\end{tabular}} & \multirow{2}{*}{$\frac{\text { DL }}{\text { NISP }}$} & \multirow{2}{*}{$\frac{\text { SUR }}{\text { NISP }}$} \\
\hline & NISP & $\%$ & NMI & $\%$ & NISP & $\%$ & NMI & $\%$ & NISP & $\%$ & NMI & $\%$ & & & \\
\hline \multicolumn{16}{|l|}{ Lamnidae (Mackerel sharks) } \\
\hline cf. Isurus oxyrinchus (Shortfin mako) & - & - & - & - & - & - & - & - & 1 & 33 & 1 & 50 & - & - & - \\
\hline \multicolumn{16}{|l|}{ Triakidae (Hound shark family) } \\
\hline cf. Mustelus mustelus (Smooth-hound) & 2 & 3 & 1 & 9 & - & - & - & - & - & - & - & - & - & - & - \\
\hline cf. Triakidae (Hound sharks ) & 4 & 6 & $* *$ & $* *$ & - & - & - & - & - & - & - & - & 1 & - & - \\
\hline $\begin{array}{l}\text { cf. Triakidae (Hound sharks)/cf. Sphyrnidae } \\
\text { (Hammerhead sharks)/ cf. Carcharhinidae } \\
\text { (Requiem sharks) }\end{array}$ & 3 & 5 & 1 & 9 & - & - & - & - & - & - & - & - & - & - & - \\
\hline Elasmobranchii (Sharks and rays) & 3 & 5 & $* *$ & $* *$ & 1 & 33 & 1 & 33 & - & - & - & - & - & - & - \\
\hline \multicolumn{16}{|l|}{ Clupeidae (Herrings, shads, sardines, menhadens) } \\
\hline Sardina pilchardus/ cf. Sardina pilchardus (Sardine) & 12 & 19 & 1 & 9 & - & - & - & - & - & - & - & - & - & - & - \\
\hline \multicolumn{16}{|l|}{ Merlucciidae (Merlucid hakes) } \\
\hline cf. Merlucciidae (Hake) & - & - & - & - & - & - & - & - & - & - & - & - & - & - & 1 \\
\hline \multicolumn{16}{|l|}{ Pomatomidae } \\
\hline cf. Pomatomus saltatrix (Bluefish) & 1 & 2 & 1 & 9 & - & - & - & - & - & - & - & - & - & - & - \\
\hline \multicolumn{16}{|l|}{ Carangidae (Jacks and pompanos) } \\
\hline Trachurus trachurus & - & - & - & - & - & - & - & - & - & - & - & - & - & - & 1 \\
\hline \multicolumn{16}{|l|}{ Sciaenidae (Croakers) } \\
\hline cf. Argyrosomus regius (Meagre) & 1 & 2 & 1 & 9 & - & - & - & - & - & - & - & - & - & - & - \\
\hline Sciaenidae (Croakers) & 1 & 2 & - & - & - & - & - & - & - & - & - & - & - & - & - \\
\hline \multicolumn{16}{|l|}{ Sparidae (Porgy family) } \\
\hline cf. Dentex gibbosus (Common dentex) & 2 & 3 & 1 & 9 & - & - & - & - & - & - & - & - & - & - & - \\
\hline Pagrus sp./cf.Pagrus sp. (Porgy) & 2 & 3 & 1 & 9 & - & - & - & - & - & - & - & - & - & - & - \\
\hline cf. Sarpa salpa (Salema) & 3 & 5 & 1 & 9 & - & - & - & - & - & - & - & - & - & - & - \\
\hline Sparus aurata (Gilthead seabream) & 1 & 2 & 1 & 9 & - & - & - & - & 1 & 33 & 1 & 50 & - & - & 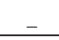 \\
\hline cf. Spondyliosoma cantharus (Black seabream) & 1 & 2 & 1 & 9 & - & - & - & - & - & - & - & - & - & - & - \\
\hline Sparidae /cf. Sparidae (Porgies) & 10 & 16 & $* *$ & $* *$ & - & - & - & - & 1 & 33 & $* *$ & $* *$ & - & - & - \\
\hline cf. Sparidae (Porgies) & - & - & - & - & 1 & 33 & 1 & 33 & - & - & - & - & - & - & 1 \\
\hline \multicolumn{16}{|l|}{ Scombridae (Mackerels, tunas, bonitos) } \\
\hline Scomber scombrus (Atlantic mackerel) & - & - & - & - & 1 & 33 & 1 & 33 & - & - & - & - & - & - & - \\
\hline \multicolumn{16}{|l|}{ Mugilidae (Mullets) } \\
\hline Liza sp. (Grey mullet) & 1 & 2 & 1 & 9 & - & - & - & - & - & - & - & - & - & - & - \\
\hline Teleostei (Ray-finned bony fishes) & 15 & 24 & - & - & - & - & - & - & - & - & - & - & - & 1 & - \\
\hline Total identified & 62 & 100 & 11 & 100 & 3 & 100 & 3 & 100 & 3 & 100 & 2 & 100 & 1 & 1 & 3 \\
\hline Undetermined & 5 & & & & - & & & & 1 & & & & - & - & 1 \\
\hline Total & 67 & & & & 3 & & & & 4 & & & & 1 & 1 & 4 \\
\hline
\end{tabular}

TABLE 8

The fish remains identified at Lameiras. Note that most were found in Early Neolithic contexts. Percentages are calculated only for the identified portions. ** These bones could only be identified to family level and so could have belonged to any of the other taxa within this family. 


\section{Sparidae - porgies}

The presence of sparids is confirmed by 19 remains $-31 \%$ of the identifiable material. They include four individual teeth, two dentary bones, an operculum, a quadrate and 11 vertebrae. The remains that could be identified to lower taxonomic level (i.e., genus or species) belong to porgy ( $\mathrm{Pa}$ grus sp. - one right dentary), dentex (cf. Dentex gibbosus - one right dentary and a precaudal vertebra), black sea bream (cf. Spondyliosoma cantharus - one precaudal vertebra), salema (cf. Sarpa salpa - three caudal vertebrae) and gilthead sea bream (Sparus aurata - one precaudal vertebra). The bones identified and their measurements are listed in appendix C. The sea bream vertebrae belonged to a fish with total length, TL $>45 \mathrm{~cm}$. The porgies (the common name for any fish belonging to the family Sparidae) are typically littoral fish, often occurring in brackish water coastal lagoons and estuaries where they feed and/or form schools. Among them the sea bream is frequent in those environments during spring (Froese \& Pauly, 2010).

\section{Elasmobranchii - sharks and rays}

12 vertebral centra, representing more than $19 \%$ of the identifiable material, belonged to elasmobranchs. The most frequent are the hound sharks (Triakidae). At least one smooth-hound (cf. Mustelus mustelus) vertebra belongs to a fish whose TL must have measured $65 \mathrm{~cm}$.

At present hound sharks include small to moderate-sized fish (up to $150 \mathrm{~cm} \mathrm{TL}$ ), while hammerhead sharks (cf. Sphyrnidae) and requiem sharks include fish that can grow up to $400 \mathrm{~cm}$ TL (Sphyrnidae) and $300 \mathrm{~cm}$ TL [Carcharinidae; Whitehead et al. (1989)]. None of the vertebrae studied belonged to oversized individuals.

More than $58 \%$ of the vertebrae studied had been intentionally perforated through the centrum - thus enlarging the notochord canal (Figure 26). This indicates an interesting secondary utilization of fish bones to produce artefacts/ornaments.

\section{Sardina pilchardus - sardine}

The presence of 12 vertebrae attests the occurrence of sardine (Sardina pilchardus) - 19\%

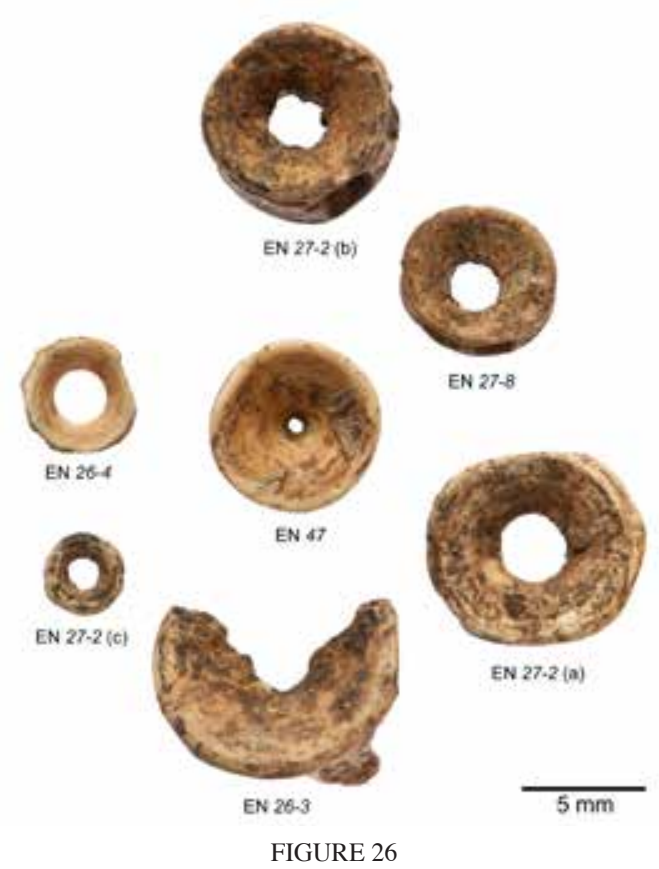

Worked fish bones from Early Neolithic Lameiras - Elasmobranchii (sharks and rays) vertebrae intentionally perforated (see Apendix $\mathrm{C}$ for measurements).

of the identified material. The measurements of a first vertebra from Lameiras indicate that it must have belonged to a fish measuring some $18 \mathrm{~cm}$ TL. The sardine is a coastal pelagic species that forms schools usually at depths of 25 to 55 metres during the day, rising to 15 to 35 metres at night (Whitehead et al., 1989). It is widely distributed in the continental shelf of Portugal to a depth ranging between 20 and 100 metres). Sardines can attain a length up to $27 \mathrm{~cm}$ and sometimes even more, although they are generally 13 to $14 \mathrm{~cm}$ long when a year old (Figueiredo \& Santos, 1989). The other taxa are poorly represented being less than $2 \%$ of the total amount of fish bones identified.

\section{Sciaenidae - croackers}

The presence of croakers (Sciaenidae/cf. Argyrosomus regius) is documented by two precaudal vertebrae. One shows signs of burning and the other crushing. Croackers are medium to large fish found in coastal waters, over muddy or sandy bottom and sometimes among rocks. Juveniles and sub-adults often enter estuaries and coastal 
lagoons. Spawning occurs offshore or along the coast, often in aggregations; the spawning season is usually prolonged from late spring to autumn. Meagre (Argyrosomus regius) adults are found inshore in shelf waters, close to the bottom as well as in surface and mid-waters, pursuing shoals of clupeids and mugilids (Whitehead et al., 1989).

\section{Pomatomus saltatrix - bluefishes}

The bluefish (Pomatomus saltatrix) represents $2 \%$ of the identified material. Its presence is attested by a caudal vertebra from an individual that measured less than $85 \mathrm{~cm}$. The bluefish is a pelagic species found along the continental shelf (Whitehead et al., 1989). Adults form loose groups, often attacking shoals of mullets or other fish (Collette, 1999). Bluefishes are often associated with sharks and billfishes (Corbera et al., 1998).

\section{Mugilidae - mullets}

The occurrence of mullets (Mugilidae, Liza sp.) is documented by a single precaudal vertebra. Mullets are medium-size euryhaline (able to live in waters of a wide range of salinities) fish. They are pelagic, and usually form schools in coastal waters, enter lagoons, estuaries and rivers for feeding, but spawn in the sea (Whitehead et al., 1989).

Besides all these fish, another 15 remains were identified simply as Teleostei (the highest superorder of ray-finned bony fish). These represent more than $24 \%$ of the identified material and include vertebrae ( 8 specimens), fin spines ( 2 specimens), and cranial bone fragments ( 5 specimens).

\section{The Evolved Early Neolithic and Late Neolithic fish assemblages}

Both the EEN and LN samples are minute when compared to the EN sample and comprise a mere seven bones. These are briefly described below. The EEN assemblage includes a vertebra of a cartilaginous fish (Chondrichthyes) and a precaudal vertebra of a sparid (Sparidae), probably a sea bream that measured less than $45 \mathrm{~cm}$ TL. Each represents $33 \%$ of the EEN collection. In addition the presence of the Atlantic mackerel (Scomber scombrus) is documented by the presence of a precaudal vertebra the other $33 \%$ of the fish remains identified in this layer. The Late Neolithic assemblage includes three teeth belonging to shortfin mako shark (cf. Isurus oxyrinchus; one specimen), and sparids (Sparidae; two molariform teeth). They each represent $33 \%$ of the fish remains identified in this layer.

\section{RECOVERY BIAS}

In the Late Neolithic, the relative scarcity of remains of small animals like fish compared to the Early Neolithic, probably reflects the greater care taken while excavating the latter (see 'material and methods' section above). Note (Table 7) the reduced percentage of rabbit and complete absence of cat and fox in the Late Neolithic. So too eight vole mandibles and an isolated vole $\mathbf{M}_{1}$ were found in the Early Neolithic and two $M_{1} s$ of this animal were found in the Mousterian but none were recovered from the Late Neolithic. And there are three field mouse mandibles recorded from Early Neolithic but none from the Late Neolithic. Recovery bias has probably therefore affected the percentages of small animals. We do not know whether it has had any effect on the recovery of the larger animals.

\section{THE FREQUENCIES OF THE DIFFERENT TAXA OF MEDIUM- AND LARGE-SIZED MAMMALS (Tables 7 and 9).}

There were clearly few remains of wild mammal in the Neolithic (even in the Early Neolithic) and Chalcolithic levels of Lameiras. In this respect Lameiras is similar to late Neolithic Belas (Davis unpub.) and Penedo do Lexim (Late Neolithic; Moreno-García \& Sousa, 2013) and also Chalcolithic Leceia (Cardoso \& Detry, 2002) and Zambujal (Driesch \& Boessneck, 1976). In all these sites situated in the Lisbon Peninsula, domesticated animals - sheep, goat, cattle and pigs - were common while wild ones were scarce. All these sites clearly differ in terms of wild: domestic fauna from Chalcolithic sites further east in the Alentejo such as São Pedro, Redondo (Davis \& Mataloto, 2012) and Porto Torrão (Arnaud, 1993) with their abundant remains of wild mammals. The high proportion of 


\begin{tabular}{|c|c|c|c|c|c|c|}
\hline & \multicolumn{2}{|c|}{ Early Neolithic } & \multicolumn{3}{|c|}{ Late Neolithic } & \multirow{2}{*}{$\begin{array}{c}\text { Chalcolithic } \\
\text { Leceia } \\
\end{array}$} \\
\hline & Caldeirão & Lameiras & Lameiras & Penedo Lexim & Belas & \\
\hline Bos & 18 & 5 & 13 & 2 & 25 & 31 \\
\hline Caprines & 22 & 56 & 60 & 49 & 51 & 31 \\
\hline Sus & 57 & 37 & 26 & 49 & 18 & 38 \\
\hline Cervus & 2 & 0 & + & + & 6 & 1 \\
\hline Capreolus & 0 & 2 & + & 0 & 0 & 0 \\
\hline Equus & 2 & + & 0 & 0 & 0 & 0 \\
\hline $\mathrm{N}_{\text {large mammals }}$ & 60 & 315 & 504 & 967 & 113 & 716 \\
\hline
\end{tabular}

TABLE 9

The Neolithic and Chalcolithic - percentages of the large mammals (of size > hare) at Lameiras, Gruta do Caldeirão (Davis, 2002), Penedo do Lexim (Moreno-García \& Sousa, 2013) and Belas (own data). Most or all the Bos and Sus are cattle and pigs respectively. Note the clear emphasis upon domesticated cattle, pigs and sheep/goat. Rabbits were also common but the variation of their percentages may reflect recovery techniques and so they have been omitted from this table (see Tables 1-5 and 7 for the counts of rabbit remains).

domestic livestock in the Lisbon peninsula may reflect the denser human habitation there in the Chalcolithic. Was human habitation of the Lisbon peninsula in Neolithic times already dense? It will be interesting to discover whether the faunal compositions of Neolithic sites in the Alentejo also included a significant wild component. So much for geographical variation in the Neolithic and Chalcolithic; were there chronological changes both within the Lameiras sequence and across the late Pleistocene to Neolithic and on to the Bronze Age in southern Portugal?

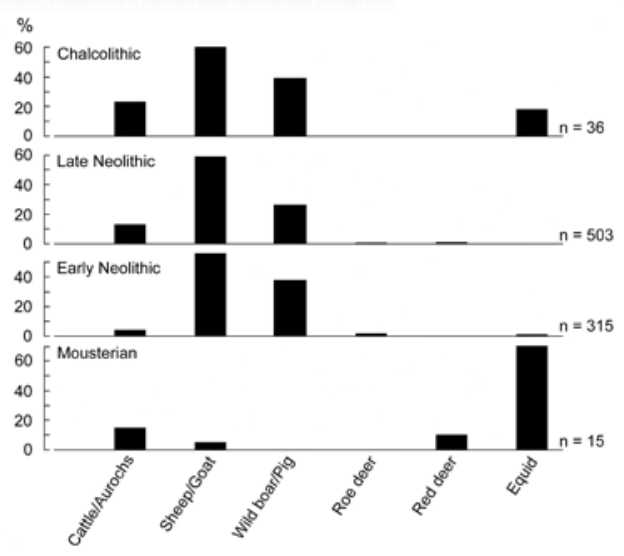

FIGURE 27

Stasis and change at Lameiras from the Mousterian to the Chalcolithic - the percentages of large mammals in the four principal levels. There was clearly little change during the Neolithic: the percentages of different taxa in the early Neolithic are similar to those in the Late Neolithic. With the exception of a small increase in the number of equids, the Chalcolithic is also similar. However, the Mousterian is characterized by its absence of sheep and, like other late Pleistocene sites in the southern half of Portugal (see Figure 28), is dominated by equids, red deer, aurochsen and goat.
Figure 27 (see also Table 7) shows the frequencies of the main large and medium-sized mammals in the four main levels at Lameiras. The difference between the Mousterian and the Neolithic is most striking. In the former period it is clear that equids, red deer and aurochsen were the dominant taxa exploited with, presumably, some wild goat. Although with such small samples these figures need to be treated cautiously, and if more material were to have been found in the Mousterian of Lameiras the number of species recorded would probably be greater. This Mousterian faunal spectrum is similar to that observed at other contemporary sites in the southern half of Portugal (see table 4 in Davis \& Moreno-García, 2007 and Figure 28) in that it is dominated by equids, red deer, goat and aurochsen - all taxa that were clearly hunted.

The two main Neolithic levels (Early and Late) show very small and probably insignificant differences and, as mentioned above, comprise predominantly caprines (mostly sheep) and pigs with some cattle and equids. Red deer is barely present at all. However, when these Neolithic levels are compared to the Mousterian, the difference is very marked; there was clearly a shift from horse and red deer to caprines.

Let us also view the Lameiras Neolithic as part of a considerable number of assemblages of faunal remains dating from the Mousterian to Bronze Age. This is depicted in Figure 28 and includes the Mesolithic remains from the Muge and Sado estuaries [data from Detry (2007); table 4 in Davis \& Moreno-García (2007)]. This chronological succession shows quite clearly a sudden and very abrupt shift from red deer to caprines (mainly sheep) that occurred between the Mesolithic and the Early Neolithic. Several other species of large mammals like 


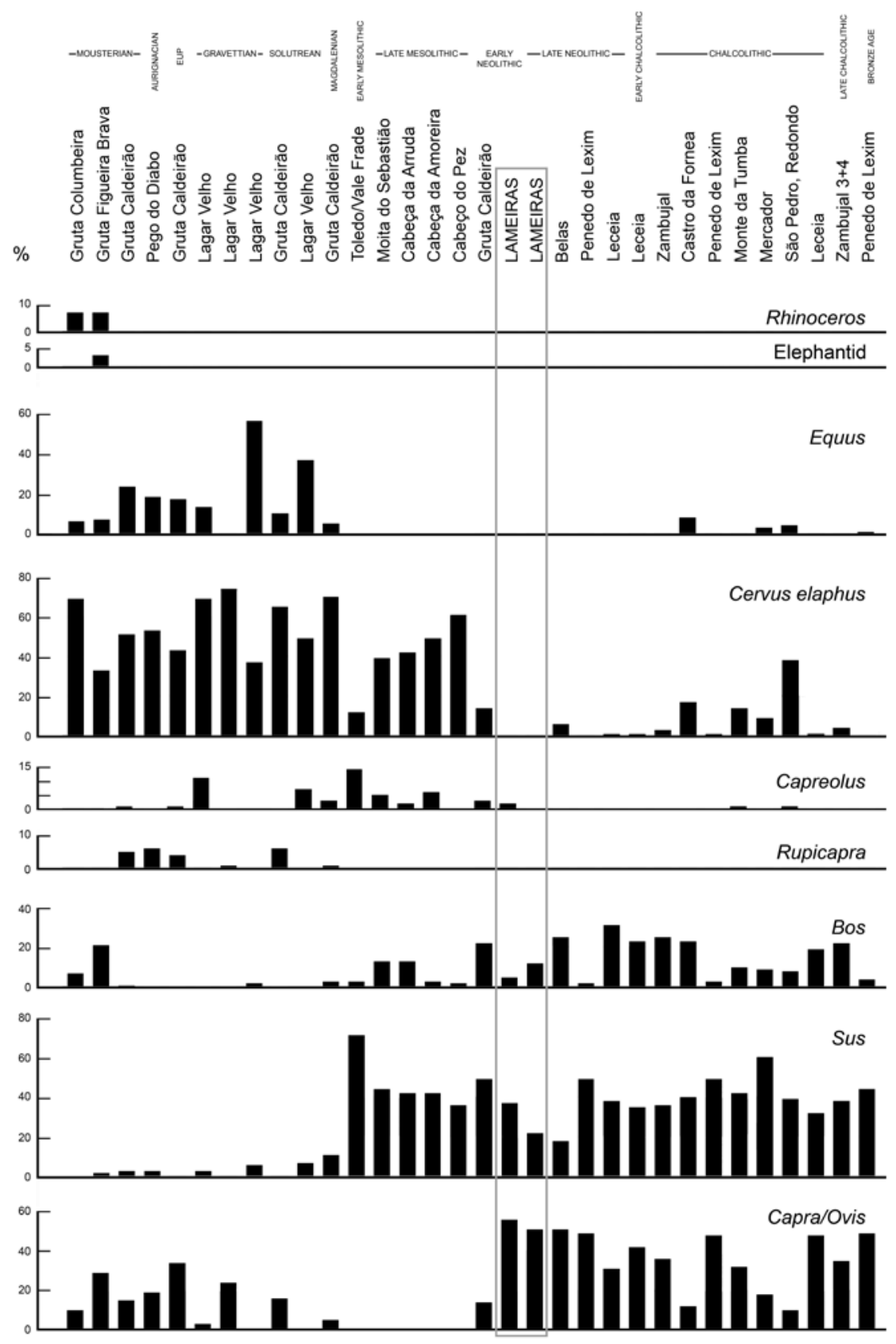

FIGURE 28

The faunal succession in the southern half of Portugal. This bar chart shows the percentages of the more common medium and large herbivore taxa found on archaeological sites and grouped by period from Mousterian to Bronze Age. Note the major faunal change from red deer to sheep and goat that occurred between the Mesolithic and Neolithic. This presumably marks the beginning of animal husbandry and the introduction of domesticated animals. The Neolithic of Lameiras clearly belongs to the 'domestic animals' side of the spectrum. Note also the earlier, Mesolithic, increase of Sus - an animal known for its ability to reproduce rapidly. Due to the difficulties in distinguishing between wild boar and pig, sheep and goat, cattle and aurochs, and the different species of equids, these are grouped as Sus, Capra/Ovis, Bos and Equus respectively. Note however, that sheep are only found from the Neolithic onwards. Equids, roe deer and chamois also seem to have been more common in the earlier periods. For clarity the vertical bars for rarer taxa are slightly enlarged. Many of these data are in table 4 of Davis \& Moreno-García (2007). 
roe deer, equids and chamois were also exploited, if to a lesser extent, before the Neolithic although some of these (Capra, equids and chamois) became scarce or even perhaps extinct in the Mesolithic.

Why were red deer and horses so scarce in the Neolithic at Lameiras? Merely comparing the Mousterian with the Neolithic at this site suggests a very significant change. But what of the intervening times? In the Mesolithic it seems there had been a shift towards exploitation of marine resources such as fish and especially molluscs (see below for further discussion). This probably reflects a relative scarcity of large mammals in the environment. We write relative, as the actual numbers of deer and equids may not have decreased to any very great extent. The increase in the human population may have been such that there were simply insufficient deer and equids to feed an ever increasing human population. It has been suggested that a gradual increase of the human population here in southern Portugal as in the Near East caused the shift from large mammals to small ones and then birds and maritime resources (Davis, 1985, 2005; Davis \& Detry, 2013). Once domesticated animals like sheep and goats were introduced, these dietary constraints were alleviated and it was no longer necessary to have to gather molluscs, fish and hunt wild mammals. Perhaps these resources (i.e., the large mammals) anyway had become scarce or even locally extinct. However in the Early Neolithic of Lameiras, fishing and gathering of molluscs did continue even though probably on a smaller scale than the Mesolithic. It was not until later times (like the Chalcolithic) that we find a substantial presence of wild animals like aurochsen, red deer and horses on some Chalcolithic sites although they appear to be smaller sites situated in the interior of the country as discussed above.

One important question is: was the change from hunting to husbandry sudden with little hunting being undertaken in the Neolithic, or was it gradual with Neolithic farmers remaining somewhat attached to their ancestors' hunting lifestyle? To provide an answer we need a multi-period site with abundant carefully excavated faunal remains from both pre-Neolithic (most importantly Mesolithic) as well as Neolithic times. Without a Mesolithic presence at Lameiras the change from Mousterian to Neolithic -from horse+red deer to sheep+goat+pig+cattle- does appear to have been quite abrupt. However, the long time gap and climate changes need to be taken into account.
A consideration of multi-period sites (in Spain) is somewhat confusing. Some show an abrupt switch at the Mesolithic-Neolithic boundary and others show a more gradual change with Neolithic farmers continuing their former lifestyle and relying quite substantially upon hunting. It is worth asking to what extent an apparent gradual change is an artefact of mixing of material from pre-Neolithic with material from Neolithic levels in a site and/or the capabilities of excavators to clearly distinguish between these two horizons.

Among those indicating a sharp shift is La Falguera (Pérez Ripoll, 2006), Cova de les Cendres (Iborra Eres \& Martínez Valle, 2009) and Cova de l'Or (Pérez Ripoll, 1980) all in Alicante. At these sites red and roe deer continue to be present in the Neolithic but in much reduced numbers. Similarly, at the Early Neolithic lakeshore site of La Draga (Banyoles) the medium-large mammals comprised $45 \%$ caprines, $22 \%$ cattle and $15 \%$ pigs while red and roe deer were extremely scarce, being less than 1\% (Antolín et al., 2014). In the Neolithic levels, 19 and 20 of the cave of Mirador (Sierra de Atapuerca, Burgos, Spain) Martín et al . (2009) also found that the fauna comprised over $70 \%$ caprines and a mere 1 or $7 \%$ Bos and $5 \%$ or less red deer. And the medium-large mammals in the Neolithic of Chaves cave, Huesca, comprise mainly caprines $(67 \%)$ with red and roe deer $11 \%$ and $1 \%$ respectively (Castaños, 2004). Among those indicating a more gradual shift may be mentioned the cave of Los Gitanos in Cantabria (Álvarez-Fernández et al., 2014) where hunting predominated $(66 \%)$ in the Early Neolithic but seems to have reduced to $54 \%$ in the later of the two EN layers, $51 \%$ in the Late Neolithic and $20 \%$ in the Chalcolithic.

That there was no general pattern in the Mesolithic-Neolithic faunal change was highlighted by Saña (2013) in her synthesis of animal domestication in the Iberian Peninsula. She noted substantial regional variations. For example in the north, Early Neolithic sites can be divided into two groups. At most sites domestic species are predominant, being over $70 \%$. But at a smaller number of sites red deer hunting predominates and some sites only have wild species. Some, too, have equal proportions of wild and domestic! But in general by the Middle Neolithic (4500-3300 cal BC) and Late Neolithic (3300-2500 cal BC) faunal composition is quite different and in these later periods domestic animals "occupy a central position... which may be 
associated with the full consolidation of stock-rearing” (Saña, 2013: 206-7).

The pattern suggested for southern Portugal when we compare the Mesolithic shell midden faunas (Detry, 2007) and even the coastal shell-midden (concheiro) site at São Julião, just $10 \mathrm{~km}$ away (Sousa et al., 2004) with Early Neolithic Lameiras indicates an abrupt change. But clearly we need more Neolithic faunal assemblages from both the Lisbon peninsula and to the east in the interior of the country.

\section{PARTS OF THE SKELETON (see Tables 1 - 5)}

Most parts of the skeleton of the more common medium and large mammal taxa are represented. There is little evidence to indicate any preference for any particular parts of the carcass. The different frequencies of the various parts of the anatomy probably reflect their density and size - i.e., their preservation and recovery (Brain, 1967; Payne, 1972).
AGE AT DEATH (see Tables 2-4 and $10-15$ and the dental ageing data in Appendix B).

Caprines. Were sheep and goat slaughtered at different ages in the Neolithic at Lameiras? It is unfortunate that too many of the Lameiras caprine bones could only be identified as "sheep/ goat". Thus once we examine the juvenile mandibles with milk teeth, and distal humeri, distal metacarpals, distal metatarsals and calcanea, sample sizes, especially for humeri and calcanea are very small. It is however intriguing that when we pool the counts for metacarpal and metatarsal (the epiphyses of these bones fuse at more or less the same age) there is some evidence that the slaughter pattern of goats may have differed from that of sheep. Thus for the metapodials, note there are $4 \frac{1}{2}$ unfused and 1 fused goat, and 51/2 unfused and 91/2 fused sheep. Put another way, the great majority of the goats were slaughtered as kids and less than a half of the sheep were slaughtered as lambs. A note of caution is necessary as $71 / 2$ unfused metapodials could not be identified as sheep or goat and therefore many or all these could have belonged to sheep. Notwithstanding this note of caution, can we argue that goats tended to be slaughtered when

\begin{tabular}{|c|c|c|c|c|c|c|c|c|c|c|c|}
\hline \multirow{2}{*}{$\begin{array}{l}\text { Site } \\
\text { Period }\end{array}$} & \multicolumn{2}{|c|}{ Lameiras } & \multicolumn{2}{|c|}{ Penedo do Lexim } & \multirow{2}{*}{$\begin{array}{c}\text { Mercador, } \\
\text { Moura }\end{array}$} & \multirow{2}{*}{$\begin{array}{l}\text { S. Pedro, } \\
\text { Redondo } \\
\text { Chalcolithic }\end{array}$} & \multirow{2}{*}{$\begin{array}{c}\text { Castro } \\
\text { Marim } \\
\text { Iron }\end{array}$} & \multicolumn{3}{|c|}{ Alcáçova de Santarém } & \multirow{2}{*}{$\begin{array}{c}\text { Silves } \\
\text { lixeira } \\
\text { Moslem }\end{array}$} \\
\hline & E. Neol & L. Neol & L. Neol & Chalcolithic & & & & Iron & Roman & Moslem & \\
\hline \multicolumn{12}{|l|}{ Tooth/Bone } \\
\hline $\mathrm{dP}_{4}: \mathrm{P}_{4}$ & 11:6 & $24: 23$ & $13: 5$ & $2: 2$ & $3: 1$ & $5: 2$ & $23: 21$ & $22: 14$ & $42: 59$ & $76: 89$ & $56: 81$ \\
\hline SC & $1: 2$ & 0:0 & $2: 0$ & $0: 5$ & $3: 0$ & $0: 1$ & $7: 8$ & $0: 20$ & $16: 34$ & $1: 71$ & $24: 73$ \\
\hline $\mathrm{HU}$ & 1:10 & 1:17 & $2: 3$ & $3: 9$ & $4: 10$ & $0: 3$ & $2: 32$ & $1: 63$ & 8:98 & $14: 132$ & $52: 117$ \\
\hline RA & $4: 4$ & $5: 0$ & $1: 0$ & $1: 1$ & $6: 2$ & $0: 1$ & $11: 2$ & $7: 7$ & $17: 13$ & $35: 26$ & $32: 16$ \\
\hline MP & $12: 5^{1 / 2}$ & $21 / 2: 2$ & $5: 3$ & $14: 9$ & $8: 2$ & $1: 2$ & $8: 61 / 2$ & $12: 161 / 2$ & $37: 371 / 2$ & $56: 59$ & $531 / 2: 751 / 2$ \\
\hline FE & $4: 3$ & 1:0 & $1: 1$ & $0: 2$ & $1: 1$ & $1: 0$ & $3: 0$ & $10: 3$ & $15: 12$ & 19:18 & $19: 11$ \\
\hline TI & $6: 7$ & $3: 5$ & $3: 2$ & $4: 3$ & $3: 3$ & $0: 5$ & $6: 12$ & $6: 48$ & $17: 70$ & $33: 90$ & $37: 120$ \\
\hline $\mathrm{CA}$ & $5: 1$ & $3: 1$ & $5: 1$ & $1: 1$ & $0: 0$ & $0: 1$ & $13: 7$ & $15: 11$ & $26: 23$ & $35: 31$ & $61: 48$ \\
\hline Pprox & $4: 8$ & $3: 4$ & $2: 0$ & $3: 6$ & $0: 4$ & $0: 3$ & $6: 30$ & $7: 20$ & $26: 74$ & $9: 71$ & $26: 193$ \\
\hline Total & $48: 46 \frac{1}{2}$ & $42 \frac{1}{2}: 52$ & $34: 15$ & $28: 38$ & $28: 23$ & $7: 18$ & $79: 1181 / 2$ & $80: 202^{1 / 2}$ & $204: 4201 / 2$ & $278: 587$ & $360^{1 / 2}: 7341 / 2$ \\
\hline$\%$ Juvenile & 51 & 45 & 49 & 42 & 55 & 28 & 40 & 28 & 33 & 32 & 33 \\
\hline
\end{tabular}

TABLE 10

Age-at-death of caprines estimated from the state of eruption of the $\mathrm{dP}_{4} / \mathrm{P}_{4}$ teeth and the fusion of limb-bone epiphyses. These are as follows: $\mathrm{dP}_{4}: \mathrm{P}_{4}$ - presence of the last milk molar tooth or its replacement - the permanent fourth premolar; $\mathrm{SC}$ - scapula-coracoid; $\mathrm{HU}$ - distal humerus; RA - distal radius; MP - distal metacarpals and distal metatarsals combined; FE - distal femur; TI - distal tibia; CA - calcaneum-tuber calcis; Pprox - proximal phalanx. Counts are shown as $\mathrm{x}: \mathrm{y}$ where $\mathrm{x}=$ the number of $\mathrm{dP}_{4} \mathrm{~s}$, unfused epiphyses or metaphyses (whichever the larger count); and $\mathrm{y}=$ the number of $\mathrm{P} 4 \mathrm{~s}$ or fused epiphyses. Single (broken) metapodial condyles are counted as halves. Counts are from larger Portuguese zooarchaeological assemblages where the total number of these teeth and bone ends is greater than 20. For São Pedro, Redondo; Castro Marim; Alcáçova de Santarém; and Silves lixeira; see Davis \& Mataloto, 2012; Davis, 2007; Davis, 2006; and Davis et al., 2008 respectively. For Penedo do Lexim and Mercador see (Moreno García \& Sousa, in press).The high proportion of juvenile caprines slaughtered at Lameiras, as well as Penedo do Lexim and Mercador, indicates that their caprine economies probably emphasized meat production. The same may have been true in the Iron Age at Castro Marim. The result for São Pedro, Redondo should be treated cautiously due to the small size of the sample at this site. 


\begin{tabular}{|c|c|c|c|c|c|c|c|}
\hline Site: & Lameiras & S. Pedro, Redondo & Castro Marim & Alcáçova de Santarém & Alcáçova de Santarém & Alcáçova de Santarém & Silves lixeira \\
\hline Period: & Neolithic & Chalcolithic* & Iron & Iron & Roman & Moslem & Moslem \\
\hline \multicolumn{8}{|l|}{ Tooth/Bone } \\
\hline $\mathrm{dP}_{4}: \mathrm{P}_{4}$ & $6: 1$ & $2: 0$ & $0: 4$ & $11: 15$ & $7: 18$ & $3: 15$ & $0: 13$ \\
\hline $\mathrm{SC}$ & $0: 2$ & $0: 3$ & $0: 1$ & $0: 14$ & $1: 16$ & $0: 27$ & $0: 20$ \\
\hline $\mathrm{HU}$ & 0:1 & $0: 3$ & $0: 6$ & $0: 12$ & $0: 20$ & $1: 32$ & $0: 18$ \\
\hline RA & $1: 0$ & $0: 4$ & $1: 1$ & $7: 9$ & 11:20 & $9: 29$ & $3: 21$ \\
\hline MP & $51 / 2: 91 / 2$ & $21 / 2: 41 / 2$ & $1: 10$ & $7: 40$ & $20: 50^{1 / 2}$ & 16:95 & $3: 62$ \\
\hline FE & 0:0 & $0: 0$ & $2: 0$ & $2: 3$ & $5: 9$ & $4: 5$ & $4: 3$ \\
\hline TI & $1: 2$ & $3: 1$ & $2: 8$ & $4: 24$ & $5: 31$ & $11: 57$ & $4: 34$ \\
\hline $\mathrm{CA}$ & $3: 0$ & $0: 1$ & 0:0 & 11:14 & $12: 16$ & $11: 19$ & $3: 14$ \\
\hline Pprox & 3:11 & $0: 4$ & $0: 23$ & $5: 78$ & $8: 96$ & $5: 127$ & 2:90 \\
\hline Total & $191 / 2: 261 / 2$ & $71 / 2: 201 / 2$ & $6: 53$ & 47:209 & $69: 2761 / 2$ & $60: 406$ & $19: 275$ \\
\hline \% Juvenile & 42 & 27 & 9 & 18 & 20 & 13 & 6 \\
\hline
\end{tabular}

TABLE 11

Age-at-death of cattle estimated from the state of eruption of the $\mathrm{dP}_{4} / \mathrm{P}_{4}$ teeth and the fusion of limb-bone epiphyses. These are as follows: $\mathrm{dP}_{4}: \mathrm{P}_{4}$ - presence of the last milk molar or the permanent fourth premolar tooth; SC - Scapula-coracoid; HU - distal humerus; RA - distal radius; MP - distal metacarpals and distal metatarsals combined; FE - distal femur; TI - distal tibia; CA - calcaneum-tuber calcis; Pprox - proximal phalanx. Counts are shown as $\mathrm{x}: \mathrm{y}$ where $\mathrm{x}=$ the number of $\mathrm{dP}_{4} \mathrm{~s}$, unfused epiphyses or metaphyses (whichever the larger count); and $\mathrm{y}=$ the number of $\mathrm{P}_{4} \mathrm{~s}$ or fused epiphyses. Single (broken) metapodial condyles are counted as halves. Counts are from larger Portuguese zooarchaeological assemblages where the total number of these teeth and bone ends is greater than 20. For São Pedro, Redondo; Castro Marim; Alcáçova de Santarém; and Silves lixeira; see Davis \& Mataloto, 2012; Davis, 2007; Davis, 2006; and Davis et al., 2008 respectively. The high proportion of juvenile cattle slaughtered at Lameiras indicates that its bovine economy was probably a meat one.

* Note that due to difficulty of separating aurochs from cattle bones, some of the São Pedro cattle may include aurochsen.

very young as kids, but a greater proportion of the sheep were kept to an older age? Why slaughter these two animals at quite different stages of their life? One possible explanation is that the goat does not produce wool (there are two exceptional central Asian breeds) and so perhaps the goats were slaughtered young merely for their meat while the sheep were kept on for their wool and milk and only subsequently slaughtered. Given the unlikely occurrence of wool- and milk-producing domestic sheep in these early times (wool production is generally considered to have begun somewhat later) another explanation is called for. These two animals behave in a rather different way. Goats tend to be more independent and will wander off on their own. They are also able to jump over enclosures, a reason why they have been uncommon on English farms since farmland became enclosed (Burke, 1837 Vol II: 505). Sheep are known for their tendency to clump together and are therefore easier to maintain in flocks. Our suggestion is that the shepherds at Lameiras, while liking both goat and sheep meat, had to slaughter the kids before they became unmanageable while the sheep could be kept to an older age before slaughter. The apparent absence of the older breeding goats is an enigma. However caution should be exercised as the proportion of juvenile (unfused epiphyses) bone can reflect preservation with the juvenile more porous and delicate bone being more subject to disintegration over time.

If we consider the limb-bones and teeth of the caprines, then approximately a half $(51 \%$ in the Early Neolithic and 45\% in the Late Neolithic) of the caprines were slaughtered as young animals before the $\mathrm{P}_{4}$ (the permanent fourth premolar tooth) had replaced the $\mathrm{dP}_{4}$ (the last milk tooth) and before the various limb-bone epiphyses had fused (see counts in Tables $2-4$ and 10 and 12). The counts for the Neolithic and Chalcolithic at Penedo do Lexim are also rather high; 49 and $42 \%$ and at Mercador slightly higher still at 55\%. These high counts of juvenile caprines probably reflect an emphasis upon the production of primary products - meat and skins rather than the so-called secondary products like wool, hair, milk and dung as well as their meat of course. Note for example the considerably lower proportion of juvenile caprines in the Iron Age to Medieval-Moslem levels at Santarém and Moslem Silves. While it is clear that at some time between the Neolithic and the Iron Age people began exploiting caprine secondary products, a clearer identification of the time when this shift occurred here on the basis of the percentages in Table 10 is not possible. Note for example the low 


\begin{tabular}{|c|c|c|c|c|c|c|}
\hline & \multicolumn{3}{|c|}{ Early Neolithic } & \multicolumn{3}{|c|}{ Late Neolithic } \\
\hline & Bos & Ovis/Capra & Sus & Bos & Ovis/Capra & Sus \\
\hline $\mathrm{N} \mathrm{dP}_{4}$ & 1 & 11 & 4 & 5 & 24 & 6 \\
\hline $\mathrm{N} \mathrm{P}_{4}$ & - & 6 & 3 & 1 & 23 & 3 \\
\hline $\mathrm{N}_{\text {bones unfused }}$ & 5 & 37 & $46^{1 / 2}$ & $8^{1 / 2}$ & $18^{1 / 2}$ & 26 \\
\hline $\mathrm{N}_{\text {bones fused }}$ & 4 & $40^{1 / 2}$ & $13^{1 / 2}$ & $21^{1 / 2}$ & 29 & 31 \\
\hline $\mathrm{N}_{\mathrm{U} / \mathrm{T}}$ & $5 / 9$ & $37 / 771 / 2$ & $461 / 2 / 60$ & $81 / 2 / 30$ & $181 / 2 / 471 / 2$ & $26 / 57$ \\
\hline$\%$ juveniles & - & $48 \%$ & $78 \%$ & & $39 \%$ & $46 \%$ \\
\hline
\end{tabular}

\begin{tabular}{|l|c|c|c|}
\hline & \multicolumn{3}{|c|}{ Early and Late Neolithic combined } \\
\hline & Bos & Ovis/Capra & Sus \\
\hline $\mathrm{N} \mathrm{dP}_{4}$ & 6 & 35 & 10 \\
\hline $\mathrm{N} \mathrm{P}_{4}$ & 1 & 29 & 6 \\
\hline $\mathrm{N} \mathrm{dP}_{4} /\left(\mathrm{NdP}_{4}+\mathrm{NP}_{4}\right)$ & $6 / 7$ & $35 / 64$ & $10 / 16$ \\
\hline$\%$ juveniles & - & $55 \%$ & $63 \%$ \\
\hline $\mathrm{N}_{\text {bones unfused }}$ & $13 \frac{1}{2}$ & $551 / 2$ & $72 \frac{1}{2}$ \\
\hline $\mathrm{N}_{\text {bones fused }}$ & $251 / 2$ & $691 / 2$ & $441 / 2$ \\
\hline $\mathrm{N}_{\text {U/T }}$ & $131 / 2 / 39$ & $551 / 2 / 125$ & $721 / 2 / 117$ \\
\hline$\%$ juveniles & $35 \%$ & $44 \%$ & $62 \%$ \\
\hline
\end{tabular}

TABLE 12

Lameiras - age at death of the cattle, caprines and pigs - Early and Late Neolithic compared and combined. These are the counts of unfused limb-bone epiphyses (data given in Tables 2, 3 and 4). Unfused refers to either unfused epiphyses (UE) or unfused metaphyses (UM) - whichever is the greater. $\mathrm{N}_{\mathrm{UT}}$ refers to the numbers of unfused epiphyses divided by the total (unfused + fused). The teeth and bones/epiphyses that are considered here are: deciduous fourth premolar $\left(\mathrm{dP}_{4}\right)$ and fourth permanent premolar $\left(\mathrm{P}_{4}\right)$, scapula-coracoid, distal humerus, distal radius, distal metacarpal, distal femur, distal tibia, calcaneum-tuber calcis, distal metatarsal, and the proximal phalanx. NB: the value here '\% juveniles' is calculated from the limb-bones only and excludes consideration of the $\mathrm{dP}_{4}$ versus $\mathrm{P}_{4}$ counts. If we include the dental counts as in Table 9 then the percentage juveniles becomes slightly greater.

numbers of juveniles in the Chalcolithic at São Pedro Redondo and the high counts of juveniles in the Iron Age at Castro Marim! Clearly more Portuguese zooarchaeological samples are needed.

Although their numbers are small and their ageat-death classes may not be quite the same as those for Lameiras, it is interesting to note that approximately $58 \%$ of the sheep and goat slaughtered in the Neolithic levels (A2, A3 and A4) at the cave of Los Gitanos (Cantabria, Spain) were juvenile (i.e., infantile+juvenile; Álvarez-Fernández et al., 2014: table 2).

Cattle. Like the caprines, the age-at-death data for the cattle at Lameiras when viewed within a long chronological sequence of Portuguese sites also reveal an interesting shift, though again there are only a few samples and the time of the shift cannot yet be accurately pinpointed. Caution is also required when interpreting these quantitative data from different sites as one important variable that can affect the percentages of juvenile bones and teeth is preservation. When soil conditions are poor, teeth and especially bones of juvenile animals are less likely to survive. Table 11 shows that at Lameiras $42 \%$ of the cattle teeth and bones were from juvenile animals - a percentage which is far higher than at any of the later sites. Note that at Roman Santarém and the two Medieval-Moslem assemblages the proportion of $\mathrm{dP}_{4}$ teeth is quite low suggesting that cattle, at least from Roman times on, were kept more especially for their secondary products - perhaps mainly power. While this certainly was not the case at Lameiras, the timing of a possible shift from meat to secondary products is difficult to ascertain. A very small sample of bones from Iron Age and Roman Odemira (Davis \& Vilhena, 2017) provides some intriguing evidence. At this site, $30 \%$ of the remains of cattle in the Iron Age belonged to juveniles - there were for example $4 \mathrm{dP}_{4}$ s and only $1 \mathrm{P}_{4}$. However, in the subse- 
a)

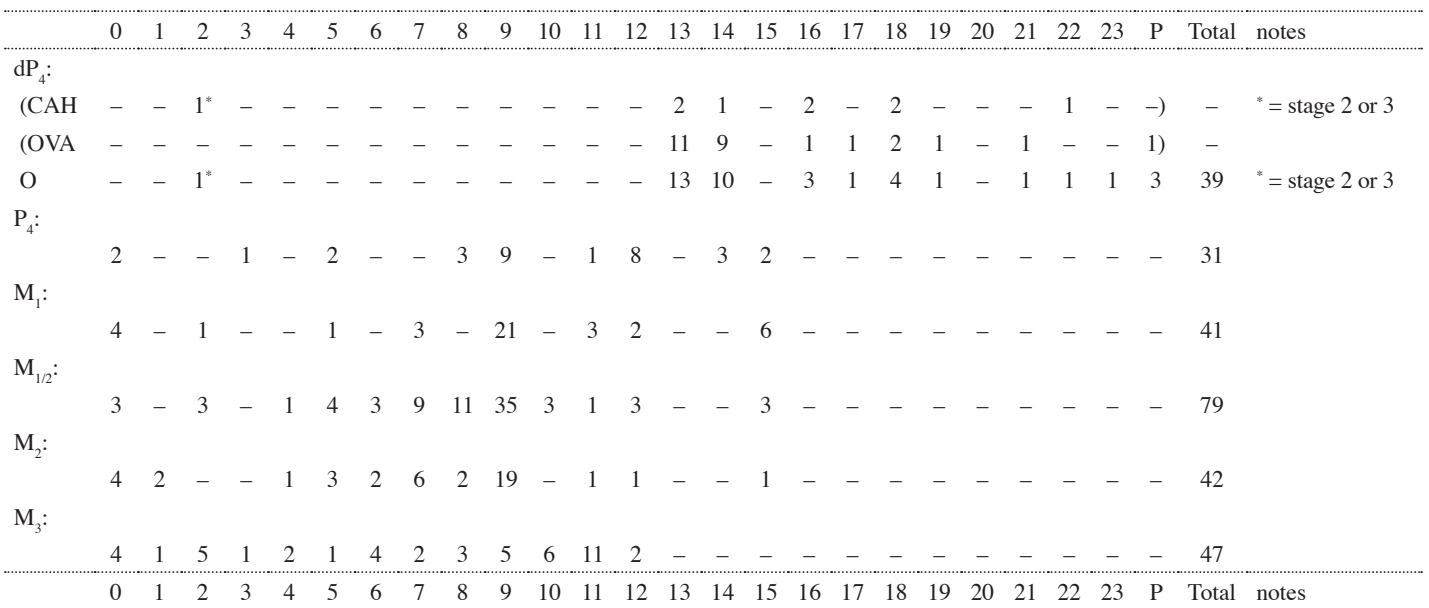

b)

\begin{tabular}{|c|c|c|c|c|c|c|c|c|c|c|c|}
\hline Stage: & A & B & $\mathrm{C}$ & $\mathrm{D}$ & $\mathrm{E}$ & $\mathrm{E} / \mathrm{F}$ & F & $\mathrm{G}$ & $\mathrm{H}$ & I & $\mathrm{n}$ \\
\hline months: & $0-2$ & $2-6$ & $6-12$ & & & & & & & & \\
\hline years: & & & & $1-2$ & $2-3$ & & $3-4$ & $4-6$ & $6-8$ & $8-10$ & \\
\hline & 0 & 3 & 3 & 4 & 6 & 1 & 5 & 3 & 2 & 1 & 28 \\
\hline
\end{tabular}

TABLE 13

Lameiras Neolithic; wear stages of the sheep/goat mandibular teeth following a) Payne (1987) above and b) Payne (1973) below.

These wear stages extend from teeth just erupted with unworn enamel (i.e., no dentine exposed) in stage " 0 " to teeth from very old animals with hardly any crown left. "P" includes teeth that could not be assigned to a wear stage. Many of the deciduous fourth premolars could be identified to species. These are shown in parentheses, "CAH" goat and "OVA" sheep. "O" includes these and the unidentified caprine $\mathrm{dP}_{4} \mathrm{~s}$. Note that one of the mandibles in stage ' $\mathrm{D}$ ' is estimated.

\begin{tabular}{|c|c|c|c|c|c|c|c|c|c|c|c|c|c|c|c|c|c|c|}
\hline & $\mathrm{a}$ & $\mathrm{b}$ & $\mathrm{c}$ & d & $\mathrm{e}$ & $\mathrm{f}$ & $\mathrm{g}$ & $\mathrm{h}$ & i & $\mathrm{j}$ & $\mathrm{k}$ & 1 & $\mathrm{~m}$ & $n$ & o & $\mathrm{p}$ & $\mathrm{P}$ & Total \\
\hline \multicolumn{19}{|l|}{$\mathrm{dP}_{4}$} \\
\hline & - & $1^{*}$ & 1 & - & - & $1^{* *}$ & - & 1 & - & 1 & - & 2 & - & - & - & - & - & 7 \\
\hline \multicolumn{19}{|l|}{$\mathrm{P}_{4}:$} \\
\hline & 1 & - & - & - & - & - & - & - & - & - & - & - & - & - & - & - & - & 1 \\
\hline \multicolumn{19}{|l|}{$\mathrm{M}_{1}$ : } \\
\hline & - & - & - & - & - & 1 & - & - & - & - & - & - & - & - & - & - & - & 1 \\
\hline \multicolumn{19}{|c|}{$\mathrm{M}_{1 / 2}:$} \\
\hline & 2 & - & - & - & 1 & 2 & 1 & 2 & - & - & 3 & 1 & - & - & - & - & - & 12 \\
\hline \multicolumn{19}{|l|}{$\mathrm{M}_{2}$} \\
\hline & 1 & - & - & - & - & - & - & - & - & - & - & 1 & - & - & - & - & - & 2 \\
\hline \multicolumn{19}{|l|}{$\mathrm{M}_{3}:$} \\
\hline & 1 & 1 & - & - & - & 1 & 1 & - & - & - & 2 & - & - & - & - & - & - & 6 \\
\hline & $\mathrm{a}$ & $\mathrm{b}$ & $\mathrm{c}$ & $\mathrm{d}$ & $\mathrm{e}$ & $\mathrm{f}$ & $\mathrm{g}$ & $\mathrm{h}$ & $\mathrm{i}$ & $\mathrm{j}$ & $\mathrm{k}$ & 1 & $\mathrm{~m}$ & $\mathrm{n}$ & o & p & $\mathrm{P}$ & \\
\hline
\end{tabular}

TABLE 14

Lameiras - Neolithic; wear stages of the cattle mandibular teeth (following Grant, 1982). These wear stages extend from teeth just erupted with unworn enamel (i.e., no dentine exposed) in stage "a" to teeth from very old animals with hardly any crown left. "P" includes teeth that could not be assigned to a wear stage. Clearly many of the cattle were slaughtered in their first 3 years of life with their milk $\mathrm{dP}_{4}$ tooth. The ratio of $\mathrm{dP}_{4}: \mathrm{P}_{4}$ is $7: 1$. This contrasts with the ratio at Silves (Moslem period) where there were $0 \mathrm{dP}_{4}$ teeth and $13 \mathrm{P}_{4}$ teeth (see table 9 in Davis et al., 2008). It is likely that at Silves the Moslems kept their cattle mainly for their energy (ploughing and transport), and so most were not slaughtered until quite old. This contrasts with the high cull of juvenile cattle at Lameiras where presumably the main interest was beef. $*=$ stage a-c, $* *=$ stage e-g. 


\begin{tabular}{|c|c|c|c|c|c|c|c|c|c|c|c|c|c|c|c|c|}
\hline & a & b & c & d & e & f & $\mathrm{g}$ & $\mathrm{h}$ & $\mathrm{i}$ & $\mathrm{j}$ & k & 1 & $\mathrm{~m}$ & n & $\mathrm{P}$ & Total \\
\hline \multicolumn{17}{|l|}{$\mathrm{dP}_{4}:$} \\
\hline & 3 & 2 & - & 4 & 1 & 1 & - & - & - & 1 & - & - & - & - & - & 12 \\
\hline \multicolumn{17}{|l|}{$\mathrm{P}_{4}:$} \\
\hline & 2 & 3 & 1 & - & - & - & - & - & - & - & - & - & - & - & - & 6 \\
\hline \multicolumn{17}{|l|}{$\mathrm{M}_{1}$ : } \\
\hline & 2 & 1 & 1 & 1 & - & 2 & - & - & - & 1 & - & - & - & - & - & 8 \\
\hline \multicolumn{17}{|c|}{$\mathrm{M}_{1 / 2}:$} \\
\hline & 7 & 1 & 2 & 2 & 2 & 1 & - & - & - & - & - & - & - & - & - & $16(+1 \mathrm{~b} / \mathrm{c})$ \\
\hline \multicolumn{17}{|l|}{$\mathrm{M}_{2}$ : } \\
\hline & 1 & 1 & 1 & 1 & 2 & - & - & - & - & - & - & - & - & - & - & 6 \\
\hline \multicolumn{17}{|l|}{$\mathrm{M}_{3}:$} \\
\hline & 5 & 5 & 1 & 1 & - & - & - & - & - & - & - & - & - & - & - & $13(+1 \mathrm{a} / \mathrm{b})$ \\
\hline & a & b & c & d & e & f & $\mathrm{g}$ & $\mathrm{h}$ & $\mathrm{i}$ & $\mathrm{j}$ & $\mathrm{k}$ & 1 & $\mathrm{~m}$ & $\mathrm{n}$ & $\mathrm{P}$ & \\
\hline
\end{tabular}

Lameiras Neolithic; wear stages of the Sus mandibular teeth (following Grant, 1982). These wear stages extend from teeth just erupted with unworn enamel (i.e., no dentine exposed) in stage "a" to teeth from very old animals with hardly any crown left.

quent two levels (Iron Age/Roman transition and Roman) none of the cattle teeth or bones belonged to juveniles. Clearly more large samples of cattle remains are needed from Chalcolithic and Iron Age sites to test the hypothesis that the exploitation of cattle power in Portugal began in the Iron Age or in Roman times. At Moslem Silves too, cattle were clearly kept well into adulthood: at that site there were no $\mathrm{dP}_{4}$ teeth and $13 \mathrm{P}_{4} \mathrm{~s}$ (see table 9 in Davis et al., 2008).

Pigs. Approximately $67 \%$ of the Neolithic pigs at Lameiras were slaughtered while still osteologically immature, with milk teeth and/or limb-bones with unfused epiphyses (see Tables $2-4$ and Table 15). This is not surprising as pigs are exploited for their slaughter products alone - pigs are not milked and do not produce wool. It does not make sense in terms of food input versus meat weight gain to keep pigs more than 2 or 3 years.

\section{AN ANOMALOUS BOS LOWER THIRD MOLAR TOOTH (Figure 29)}

Unlike the first and second lower molar teeth of artiodactyls which each possess two pillars, the lower third molar is characterised by having three. Note as an example the large aurochs $\mathbf{M}_{3}$ from the Mousterian of Lameiras on the left side of this figure. The posterior pillar or cusp is the hypoconulid. Occasionally in cattle, and perhaps in other artio- dactyl taxa, third molars have a reduced or completely absent hypoconulid. This may have something to do with inbreeding (O'Connor, 2000: 121; Argant et al., 2013). If found as an isolated tooth - i.e., detached from the mandible ramus, such a tooth could easily be mistaken as an $\mathrm{M}_{1}$ or $\mathrm{M}_{2}$. This means that occurrences of this phenomenon are probably under-estimated. The specimen here from UE 103 (Evolved Early Neolithic) is within the mandibular ramus and so is clearly a third molar tooth. Note that apart from the base of the crown, the hypoconulid is absent. According to Thierry Argant who is compiling records of known occurrences of this strange phenomenon, the specimen shown here from Lameiras is the earliest example known so far (Argant, pers. comm.; Argant et al., 2013).

\section{BOTANICAL REMAINS -FURTHER EVIDENCE FOR AGRICULTURE AT LAMEIRAS}

Thanks to careful recovery by sieving, many plant remains were discovered. These have been studied by López-Dóriga \& Simões (2015). Among the wide spectrum of remains found in the Early Neolithic, she identified Hordeum vulgare (barley), Triticum aestivum/durum (bread/macaroni wheat) and Triticum dicoccum (emmer wheat). She also found Lens culinaris (lentil), Pisum sativum (pea), Vicia faba (broad bean) and V. sativa (vetch). These plants were first domesticated in the Near East and therefore indicate that the Early Neolithic 


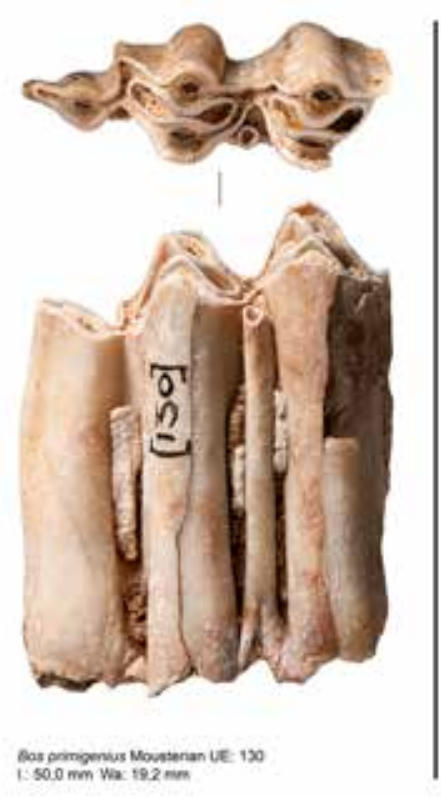

is $500 \mathrm{~mm}$ War: $19.2 \mathrm{~mm}$
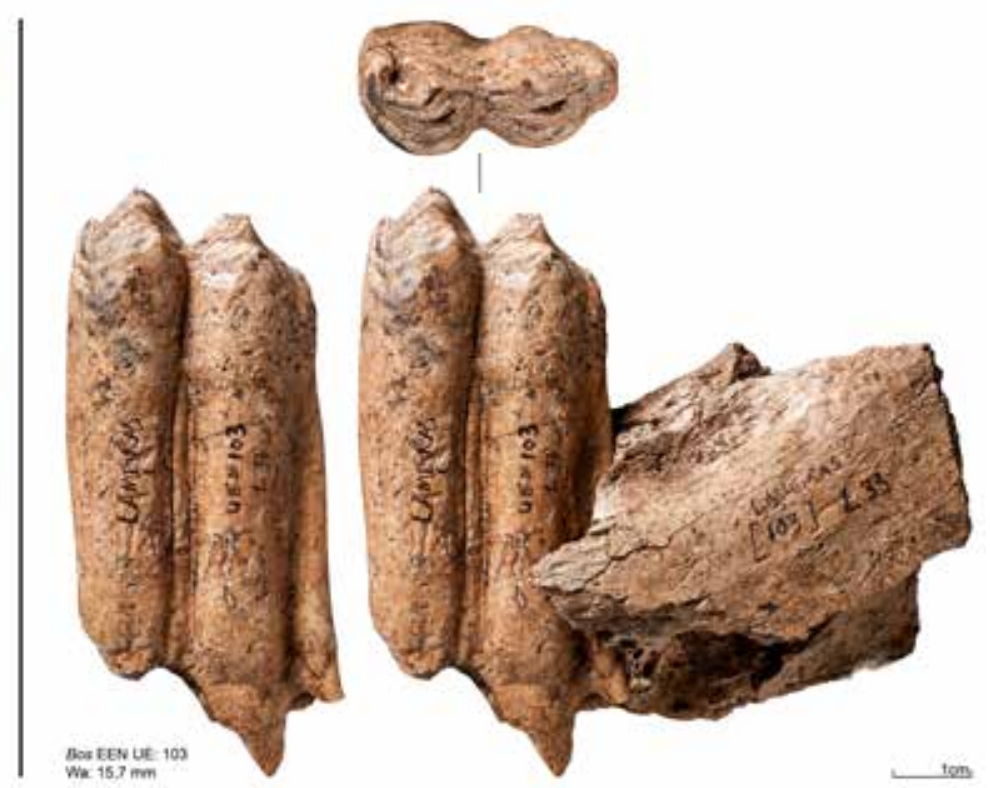

FIGURE 29

Two lower third molar teeth of Bos (aurochs/cattle) in occlusal (above) and buccal views (below) from Lameiras. The isolated $\mathrm{M}_{3}$ on the left is from the Mousterian and presumably belonged to an aurochs. Note that it has the three columns; the posterior one known as the hypoconulid. This is the normal structure. The M3 on the right, shown both separated from the mandible ramus and within the ramus, is abnormal in that it lacks a hypoconulid. This latter specimen is from the Evolved Early Neolithic and with its anterior crown width ('Wa') of $15,7 \mathrm{~mm}$ it probably belonged to a domestic animal. ' 1 ' = maximum antero-posterior crown length.

inhabitants of Lameiras were farmers. Moreover, López-Dóriga also found emmer/einkorn and macaroni wheat chaff which (we are grateful to João Tereso for pointing this out to us) represents the waste residue derived from processing the cereal after harvest. This presence of chaff serves as yet another indicator of agricultural practise. With the presence of cereal and other grains one could argue that they were simply purchased by the inhabitants of Lameiras. But then why would they also buy the waste products of their processing? In sum therefore, given not only the presence of exotic cereals and grains but also the waste from emmer processing, as well as sheep bones, it is quite clear that the inhabitants of Lameiras were principally farmers.

\section{DISCUSSION}

An understanding of the fauna of Lameiras could have some bearing upon the history of the people of southern Portugal: how did the Neolithic way of life arrive here? Was it adopted gradually, or did it come suddenly? Put another way, did farmers spread their technology and their domesticated animals so that local hunter-gatherers slowly adopted farming - the 'cultural diffusion' explanation (Ammerman \& Cavalli-Sforza, 1984) or did husbanding and farming suddenly take over - a scenario that suggests (admittedly rather speculatively) that there could have been a change of the human populations at that time, a scenario that Ammerman and Cavalli-Sforza call 'demic diffusion'. Palaeogenetic studies of human bones of both farmers and hunter-gatherers in Europe and the Near East are suggesting the possibility of a mixture of both cultural diffusion and migration from the Aegean and/or Near East (Hofmanová et al., 2016). That a mixture of the two occurred and that the proportions between them varied according to locality in Europe has also been suggested via mathematical modelling (Fort, 2015). Take the case of Britain. Mesolithic and Neolithic faunal assemblages in southern Britain indicate that sheep and often goats too are present in nearly all Early Neolithic settlements there (Serjeanston, 2014). Both 
the scarcity of wild animals and presence of sheep and goats support the theory of an immigrant population rather than one which added farming to an already existing hunting and gathering lifestyle. The animal data from southern Britain do not support the theory that there was a gradual acculturation of the Mesolithic people, rather the Neolithic arrived all together and the principal domestic animals became the mainstay of economic and social life from the earliest Neolithic. An abrupt shift in diet at the onset of the Neolithic not only in Portugal but also in Denmark and coastal Britain is indicated by the carbon isotope $\left(\delta^{13} \mathrm{C}\right)$ ratios found in human bones. These indicate a sudden change from a marine to a terrestrial-based diet (Tauber, 1981; Lubell et al., 1994; Richards et al., 2003). Tresset \& Vigne (2011) note that in Brittany and Scotland Mesolithic and Early Neolithic sites indicate a 'sudden' shift from marine to terrestrial food between roughly 4400 and 3900 cal BC for Brittany and Scotland respectively. These authors also highlight the fact that in general throughout Europe, late Mesolithic peoples exploited a wide spectrum of animals including molluscs, fish, birds and mammals while Neolithic diets were less diverse and were mostly terrestrial and often domestic. Recent isotope studies undertaken here in Portugal by Guiry et al. (2016) also indicate "a relatively sharp and sustained shift to terrestrial foods at the onset of the Early Neolithic". Take one other example of Vela Spila in Croatia. In their report on the fauna, Rainsford et al. (2014) write: "Fishing at the site changed from one of the primary activities in the Mesolithic, contributing significantly to subsistence, to a small-scale and opportunistic activity in the Neolithic, taking up little time and providing a modest source of protein". We suggest that a similar change happened here in southern Portugal. Whether the Mesolithic human population was totally replaced or people suddenly adopted a new kind of lifestyle, or even a combination of the two, will be difficult to determine, and of course may have varied from region to region as Saña (2013) has suggested (see above). So much for chronological changes in southern Portugal; let us now compare events here with those that had already occurred thousands of years earlier and thousands of kilometres to the east.

Many have pinpointed the Near East - in particular the so-called Fertile Crescent - as the location where many of our principal domesticated animals were first domesticated (see above under Ovis/ Capra - sheep/goat). In recent years, substantial advances have been made in the study of food-animal domestication in the Near East - the region in which domestic sheep originated. When, then, were sheep first domesticated in that region?

One convincing study that provides a date for sheep domestication is that of Peters et al. (2005). An important criterion for distinguishing between domestic animals and their wild ancestors is size, as we discuss here. Domestic sheep, goat, cattle and pigs are all smaller than their wild relatives. But size in many mammals also varies geographically and with the temperature of the environment. By studying archaeological animal bones from sites in a restricted region - the Upper Euphrates-Tigris basin - Joris Peters and his group managed to essentially 'control' geographical variation. They have also managed to 'control' environmental temperature variation by considering not only taxa that were domesticated (sheep, goat, wild boar/pig, and aurochs/ cattle) but also a species - the gazelle - that was not domesticated. They show that gazelle did not undergo any significant size decrease during the $9^{\text {th }}-7^{\text {th }}$ millennia cal BC when the lineages of the other four taxa did, after the final Pre-Pottery Neolithic ' $A$ ' period (PPNA) and during the subsequent PPNB. Hence if temperature were the cause of the diminution during that time one should expect the gazelles to have become smaller but they did not presumably because environmental temperatures remained constant during these millennia. Hence the size decline of the caprines, Sus and Bos, is more likely to reflect their change in status from hunted to husbanded. Peters suggests a probable date for sheep and goat domestication of approximately $8450 \mathrm{cal} \mathrm{BC} \mathrm{(Peters} \mathrm{et}$ al., 2005; Peters, pers. comm.).

That the mid $9^{\text {th }}$ millennium BC saw sheep husbanded in the Near East is corroborated, if a little later, by the dates for the earliest remains of sheep on the island of Cyprus. This island has been isolated from the mainland for some five million years since the Messinian salinity crisis (Hsü et al., 1973). And prior to Neolithic human colonisation, Cyprus was populated by a strange endemic fauna of pygmy hippopotamus and pygmy elephant (Forsyth Major, 1902; Bate, 1903, 1906; Boekschoten \& Sondaar, 1972). The early, but not the earliest, human colonisations of this island saw the shipment of sheep as well as other livestock, from the mainland. This act, like the changes reported in the Upper Euphrates-Tigris basin, provides an early date for the domestication of sheep: it is reasonable to suppose that it was domesticated or tamed animals rather 
than their wild relatives that were transported. In 'phase ancienne B', dated between 8000 and 7900 cal. BC at one of these early Cypriot sites, Shillourokambos, Jean-Denis Vigne has identified the earliest remains of sheep in Cyprus (Vigne, 2011; Vigne et al., 2011 and pers. comm.). These finds of sheep bones beyond the natural range of distribution of this animal provide a sure sign that they had already been domesticated. Thus we now have dates of $8450 \mathrm{cal}$. BC from the Upper Euphrates-Tigris basin and 8000-7900 cal. BC from Cyprus. Thus these dates along with ours from Lameiras allow us to estimate ovine velocity in prehistoric times.

We shall assume then that sheep were domesticated in the mid $9^{\text {th }}$ millennium cal. BC in the Near East. This date is some three millennia before the Early Neolithic in the southern Iberian Peninsula and the direct radiocarbon dates of $\mathrm{c}$. 5450 cal BC obtained on the four Early Neolithic sheep bones from Lameiras (see above), as well as those of 5500-5250 BC from Caldeirão cave (Zilhão, 2000) - the earliest domesticated sheep in Portugal known so far and a mere two centuries after the first appearance of the Early Neolithic in Languedoc (Rowley-Conwy et al., 2013). Given that the ancestors of our Portuguese sheep came from the Near East and with the dates at hand we can calculate approximately how long it took for sheep to walk overland from east to west. A terrestrial route of some $4877 \mathrm{~km}$ (this distance was calculated in a very arbitrary manner from Aleppo to Sintra via Istanbul, Tirana, Zagreb, Marseilles, Valencia, Málaga and Ayamonte) and a difference of some 3000 years would mean sheep travelled at a speed of 1,6 kilometres per year! As Zilhão (2000) points out, this is considerably faster than the $1 \mathrm{~km}$ per year proposed by Ammerman \& Cavalli-Sforza (1984) in their "Wave of Advance" model. [Further calculations based upon a considerably larger number of dated sites were made by Pinhasi et al. (2005) who suggested that agriculture spread across Europe at a rate of between 0,6 and 1,3 km per year.] Such a rapid spread of sheep (i.e., the Neolithic 'package' or way of life) means that sheep and the Neolithic peoples may well have come to the southern part of the Iberian Peninsula in boats (Zilhão, 2000) - the 'maritime pioneer model'. A similar line of reasoning was made by Rowley-Conwy et al. (2013) in their discussion of the evidence for the first appearance of domestic animals in Italy, Istria, the Tyrrhenian islands and southern France. They note the lack of any sign of continuity between the Mesolithic and the Early Neolithic in these regions and also the rapid spread of the Neolithic in southern Greece $(6400-6000$ cal BC) to southern Italy $(6000-5700 \mathrm{cal} \mathrm{BC})$ to Sardinia/Corsica as well as Languedoc (5700/5600 cal BC). They also suggest that initial forays by colonising farmers were made by sea and that the numerous islands of this region served as stepping stones for maritime transfers enabling Neolithic peoples to leapfrog hunter-gatherer enclaves in eastern Liguria and the Rhône delta. Isern et al. (2017) note that the abundance of reliable radiocarbon dates on Early Neolithic European materials done in the last 15 years corroborate the 'maritime pioneer model' and in their modelling of the spread of the Early Neolithic in the western Mediterranean they show that "sea travel is required to obtain reasonable predictions with a minimum sea-travel range of $300 \mathrm{~km}$ per generation. They also suggest that the Neolithic was spread via leapfrog coastal dispersal. That people were navigating the sea in those early times is attested by colonisation of Mediterranean islands like Cyprus in the first half of the $9^{\text {th }}$ millennium $\mathrm{BC}$ and even earlier transport of obsidian from the island of Milos in the Cyclades to Franchthi cave in Argolis, Greece (Dixon \& Renfrew, 1973).

Thus the dates we have from Lameiras at the very least provide corroborative evidence for the early presence here in southern Portugal of sheep and the possibility that they were shipped to coastal Portugal rather than having had to have been shepherded across the Iberian Peninsula by a land route or around the southern Iberian coastal regions.

And what happened elsewhere in the Iberian Peninsula? Besides the dog, domesticated animal remains have not been reported from before the last third of the fourth millennium BC in Navarre and País Vasco, while in Alto Aragón there is evidence for domesticated food animals dated to $\mathrm{c}$. 4820 - 4170 BC (Castaños, 1995). Zilhão (2000) concluded that there are no signs of food production in northern Spain securely dated to a time before c. $4100 \mathrm{BC}$. We can therefore suppose that it took over a thousand or even more years for sheep to cross (or circumnavigate) the Iberian Peninsula! Taking, again rather arbitrarily, the distance from Lameiras to Bilbao - some 700 kilometres, sheep crossed the Iberian Peninsula at a rather slow rate of a mere 0,3 kilometres per year. This 'velocity' stands in marked contrast to the speed with which sheep traversed southern Europe from the Near 
East to Lameiras suggested above of 1,6 kilometres per year! It is possible that the dates we have so far from northern parts of the Iberian peninsula are not the earliest, but for the time being it seems the east-west spread of domesticated animals was considerably faster than their spread north. These differences in the speed of the Neolithic spread, as Fort (2015) points out in his mathematical modelling of the Neolithic transition in Europe, may reflect the predominance of demic diffusion from east to west and cultural diffusion from south to north. A factor he also mentions that could have aided rapid spread of agriculture across southern Europe and hindered its transmission towards the north is the degree to which Near Eastern crop plants were able to adapt to environmental conditions in more northern latitudes (see Cockram et al., 2007). Perhaps also the peoples inhabiting northern Iberia simply had no need to husband food animals in the sixth and fifth millennia BC as Rowley-Conwy (1984) suggested for northern Germany versus Denmark: he noted that Bandkeramic farmers reached north central Germany around 4500 BC but the Danes with their Mesolithic Ertebølle culture did not adopt agriculture for another thousand years. Most Ertebølle people were settled, and coastal resources played a large role in their subsistence. Rowley-Conwy suggests that foraging was at least as attractive as farming, with oysters filling a vital gap in the seasonally available resources in the spring. So why then did agriculture suddenly appear a thousand years later? Towards the end of the fourth millennium BC, sea level and coastline changes in Scandinavia led to a fall in the salinity of the sea in western Denmark, below that tolerated by the oyster. Ertebølle hunter-gatherers would have had to contend with intermittent ecological crises. And these led to the eventual need to adopt farming. Were people in southern Portugal forced to switch from hunting to husbanding in the sixth millennium BC and people further north did not face this need until considerably later? These changes were, it has been suggested, the result of increasingly scarce terrestrial food resources due to increased demographic pressure which initially led to a shift to hunting smaller animals, birds and fish and subsequently the need to take control of food sources by husbanding animals (Flannery, 1969; Davis, 1985; Munroe, 2001; Davis, 2005; Davis \& Detry, 2013). In other words 'need was the mother of invention' (Boserup, 1965).
If indeed the newly arrived Neolithic people came by sea, one should wonder about the nature of the boats they used. They must have been sufficiently large to accommodate livestock and allow them to stand and perhaps even move about. This may have been safer than tying them in the bottom of a boat as is often done for deer during maritime voyages in the Andaman Islands today (Clutton Brock, 1981: figure 18.6). As Vigne (2014) has pointed out, after lying down for 3-4 hours without moving, ruminants suffer from what is known as "downer cow syndrome" leading to ischemic necrosis of the hind limbs and other disorders.

We need also to inquire whether the Early Neolithic at Lameiras included all the main domesticated species or just sheep and goat - smaller ruminants that may have been easier to transport standing up and moving around the deck of a boat. For the arrival of domestic cattle and pigs was it, for example, necessary to wait until the end of the Neolithic? Figure 23 shows quite clearly that most of the Early Neolithic Sus humeri are very small and therefore belonged to pigs rather than wild boar. Unfortunately there are few diagnostic bones of Bos in the Early Neolithic providing a clear distinction between wild and domestic forms. But the two distal metatarsals (one has both condyles and the other only one; Appendix A) are more likely to have belonged to cattle than aurochsen (see Figure 30). Moreover, the metatarsal with both condyles joined, has a distal width (BFd) of $54,0 \mathrm{~mm}$. This falls well within the measurements of domestic Bos metatarsals from Chalcolithic and later times in Portugal and is considerably smaller than an aurochs metatarsal from Mesolithic Cabeço da Pez whose BFd measures $77,4 \mathrm{~mm}$. According to Driesch \& Boessneck (1976) the BFd values for cattle metatarsals range from 52 to $64,5 \mathrm{~mm}$ while aurochsen range from 66,5 to $76 \mathrm{~mm}$. Hence using the Zambujal collection as a benchmark, we can again presume that the Early Neolithic Bos metatarsal from Lameiras belonged to a domestic animal and not the aurochs. Therefore it appears likely that the Early Neolithic farmers at Lameiras, like their later Neolithic descendents, herded cattle and pigs as well as sheep and goat. Did the Early Neolithic sailors manage to transport cattle and pigs as well as sheep and goats? The answer to this question does seem to be yes. And this would also mean that nautical engineering here 7500 years ago was already in quite an advanced state. 


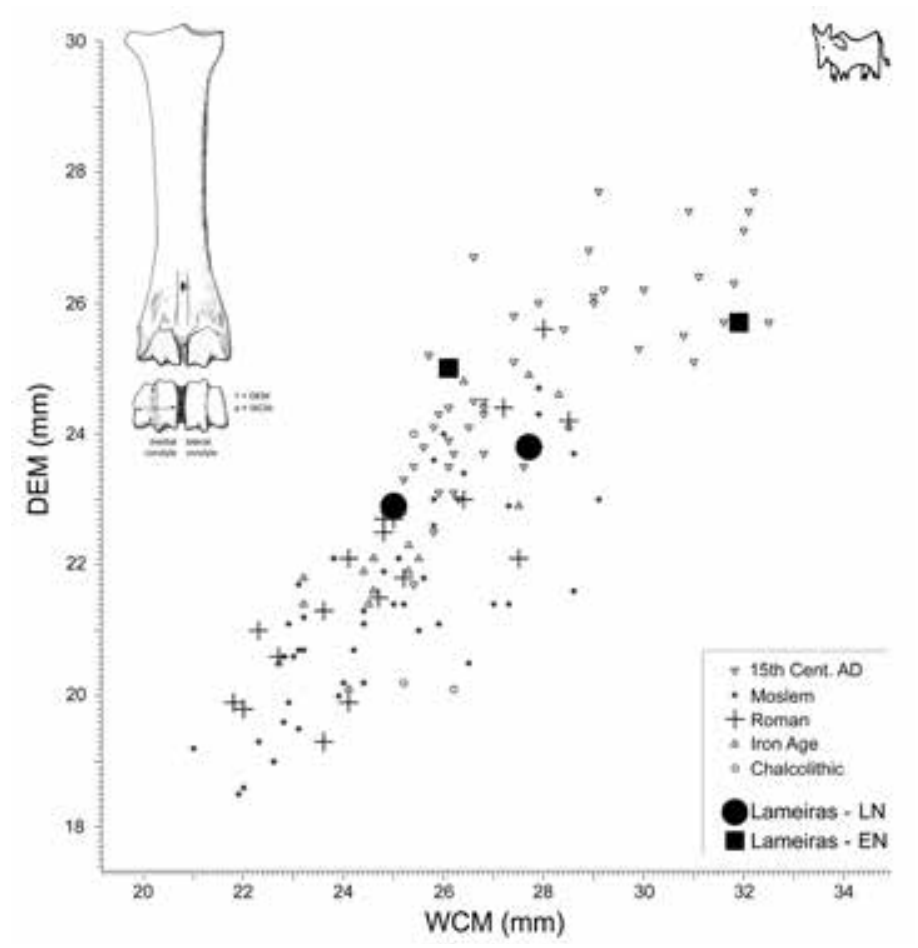

FIGURE 30

Medial condyles of Bos metatarsals from the Early Neolithic (EN) and Late Neolithic (LN) at Lameiras compared to Portuguese Chalcolithic to $15^{\text {th }}$ century AD cattle. This is a plot of the depth of the medial trochlea (DEM) against the width of the medial condyle (WCM). Both the Early and the Late Neolithic Bos metatarsals fall among the domesticated animals and so probably belonged to cattle rather than aurochsen.

\section{FISH}

Where the fish are concerned, the location of the site, $143 \mathrm{~m}$ above sea level and some $10 \mathrm{~km}$ from the coast, excludes the possibility that we are dealing with the remains of natural death events, while the presence of burned bone and intentionally modified vertebrae prove interference by humans. It is possible to ascribe the Early Neolithic fish assemblage to two major taphonomic groups (sensu Gautier, 1987): a) consumption refuse and b) workshop/manufacture use.

The small numbers of remains that characterize the fish assemblages makes it difficult to evaluate the possible presence of more or less complete skeletons and the manner in which fish were processed. The presence of sardines is also difficult to interpret. They are present in small numbers and may well come from contemporary intrusives brought to the site in the stomach contents of predatory fish such as sharks and meagre.
Although the image of fish procurement could be biased by taphonomic pathways and even the archaeologists' own making (i.e, ability to recognize fish remains as such), something can be said about the exploitation of aquatic biotopes and fish use during the Early Neolithic.

\section{Biotope exploitation and fishing.}

All the identified fish bones from Lameiras are marine and estuarine, indicating the exploitation of the coastal realm. It is interesting to note the association of sharks, croackers and bluefish. These all prey on schools of fish like sardines and mullets that are also represented in the assemblage. Fish diversity thus suggests the exploitation of coastal benthopelagic realms (i.e., near the bottom as well as in midwaters or near the surface), where the porgies too could have been caught.

Reconstructing how fishing was organised during the Early Neolithic is also difficult, since 
fishing gear is completely absent - presumably not preserved. Hence only the fish remains themselves can offer some basis for speculation. If no bias was introduced during excavation, favouring the recovery of larger specimens, we suggest that people from Lameiras sought medium/large sized fish rather than small ones, possibly using more than one kind of gear: fish traps, nets, hooks and spears (the last only for the larger species).

Few Mesolithic and Neolithic sites with fish remains are known in Portugal. The fish assemblages reported so far include some 8808 remains from 11 sites. These are Early Mesolithic Toledo and Vale de Frade (Gabriel, 2011; Araújo et al., 2014); Late Mesolithic Cabeço da Amoreira (Tagus), Cabeço da Arruda (Lentacker, 1986, 1994), Arapouco, Cabeço das Amoreiras (Sado), Poças de São Bento, Samouqueira, Fiais (Gabriel et al., 2012; Gabriel, 2015) and Vidigal (Le Gall et al., 1992, 1994); Neolithic Barrosinha (Gabriel, 2015) (Figure 1).

Fish assemblages found in Cabeço da Amoreira $(\mathrm{N}=2724)$, Barrosinha $(\mathrm{N}=1960)$, Arapouco $(\mathrm{N}$ $=1895)$, Samouqueira $(\mathrm{N}=902)$ and Vidigal $(\mathrm{N}=$ 465) are the most abundant, with higher fish frequencies. These sites span the Late Mesolithic and Neolithic suggesting that fish are worth considering in the food economy of both periods.

Except for Cabeço da Arruda, Cabeço da Amoreira (Tagus), Arapouco and Vidigal, where freshwater environments were also exploited, most fish found at these sites belonged to marine species. As in Lameiras, the most frequent taxa in most of these samples were sparids and sharks, as well as some mullets and croackers suggesting similar technology/methods of fishing. It is likely that the sardines at Lameiras probably reflect the more careful recovery methods used when Lameiras was excavated.

\section{Secondary uses of fish.}

The occurrence of sharks in the marine environment has made them an attractive and intriguing resource for numerous maritime societies. Sharks are rich in protein, vitamin A, and oil (Olsen, 1999) and have been identified in coastal archaeological sites around the world where they were used for food and other purposes including their teeth, spines and vertebrae to produce fish hooks, weapons, and ornaments (Rick \& Erlandson, 2002).
The shark assemblage found in Lameiras is especially interesting, as it shows the intentional transformation of their skeletal remains, most probably to produce ornaments.

\section{CONCLUSIONS}

The dominant species of medium - large-sized mammal in the Early Neolithic of Lameiras is the sheep. Its identification is confirmed both morphologically on the basis of characters on the last milk molar tooth, the distal humerus and the distal metacarpal, the astragalus and terminal phalanx; and metrically on the basis of the shape of the distal metacarpal and the astragalus.

Direct ${ }^{14} \mathrm{C}$ dates were obtained on five of the sheep bones - four distal humeri and one distal metacarpal. Four (three humeri and the metacarpal) date clearly to the Early Neolithic and three of these (two of the humeri and the metacarpal) belong to the mid $6^{\text {th }}$ millennium $\mathrm{BC}$ which represents the very beginning of the Early Neolithic of Portugal. Thus domestic sheep arrived here in the far west of Europe some three millennia after their initial domestication in the Near East - almost $5000 \mathrm{~km}$ away - at a velocity of some 1,6 km per year. This provides further corroboration of a rapid spread of husbanded livestock - substantially faster than Ammerman \& Cavalli-Sforza (1984) hypothesised for an overland 'wave of advance'. Hence sheep may well have been shipped for part or the entire journey as Zilhão (2001) and others have suggested.

A consideration of the Lameiras Neolithic fauna within the southern Portuguese late Pleistocene Holocene succession of mammals suggests that the switch to animal husbandry was sudden and that, at least at Lameiras, hunting of mammals and fishing was only continued on a very small scale. Whether local hunter-gatherers leading a Mesolithic lifestyle rapidly changed their way of life and obtained/ purchased domesticated livestock, or were driven out of the land by incoming farmers remains to be seen. Perhaps the truth lies somewhere in between.

It is likely, given the high proportion of slaughtered young, that the caprines, pigs and cattle were kept for their slaughter products such as meat, fat and skins rather than (at least for the caprines and the cattle) being maintained for wool/hair, 
milk and power. For a substantial change in the pattern of animal husbandry we have to wait until the Chalcolithic when, at Penedo de Lexim for example, a shift occurred and more of the caprines were slaughtered when mature (Davis \& Moreno-García, 2007).

The metrical data for the Canis, Bos, Capra, Ovis and Sus at Lameiras when placed amongst the late Pleistocene-Holocene sequences for these taxa confirm the small size and therefore domesticated status of most (even all) of the bones of these taxa at Lameiras.

If no recovery bias occurred during the excavation of Lameiras, then we can propose that the fish procured were mainly mid-large size marine species like sparids and sharks.

It is hoped that these descriptions that we present of the animal remains from Lameiras will serve future studies of the Neolithic in the Iberian Peninsula.

\section{ACKNOWLEDGEMENTS}

We are most grateful to numerous colleagues for their kind help: Diego Angelucci, introduced SJMD to the site of Lameiras; Pablo Arias arranged to have the sheep bones radiocarbon dated; Cleia Detry supplied measurements and other data from Muge; numerous colleagues generously supplied measurements of material they are studying, or have studied, or allowed SJMD to measure their bones. They include Nelson Almeida, Diego Álvarez-Lao, Pedro Castaños, Francisco Correio, Claudia Costa, Joan Daura, Cleia Detry, Carlos Fernández, Tiina Manne, Mariana Nabais, Montserrat Sanz, Maria João Valente and Elizabeth Wright. Rebecca Banasiak took the time to measure Iranian and Iraqi wild sheep and goat astragali housed in the Field Museum of Natural History, Chicago. For useful discussions about the Mesolithic and Neolithic of Portugal we thank Ana Cristina Araújo and João Zilhão. António Faustino Carvalho answered various queries concerning dates. Alain Le Brun and Jean-Denis Vigne helped to clarify questions about the early Neolithic in Cyprus. Alex Valenzuela and Josep Alcover provided feral goat skeletons from Mallorca. And Alfredo Sendim and António Abel continue to provide skeletons of merino sheep and Barrosã cattle. José Paulo Ruas took the excellent photographs and Ana Costa supplied the map in Figure 1.

\section{REFERENCES}

Albarella, U.; Davis, S.J.M.; Detry, C. \& Rowley-ConWY, P. 2005: Pigs of the "Far West": the biometry of Sus from archaeological sites in Portugal. Anthropozoologica 40: 27-54.

Albarella, U.; Dobney, K. \& Rowley-Conwy, P. 2006: The domestication of the pig (Sus scrofa): new challenges and approaches. In: Zeder, M.; Bradley, D.G.; Emshwiller, E. \& Smith, B.D. (eds.): Documenting domestication; new genetic and archaeological paradigms: 209-227. University of California Press, Berkeley.

Álvarez-Fernández, E.; Altuna, J.; Barrera-Mellado, I.; Cubas, M.; Fernández-Gómez, M.J.; FernánDeZ, R.; Gruet, Y.; Mariezkurrena, K. \& Ontañón, R. 2014: Évolution de l'exploitation des ressources animales dans la région cantabrique entre 4500 et 2000 cal BC: la grotte de Los Gitanos (Cantabrie, Espagne). Comptes Rendus Palevol 13: 307-314.

Ammerman, A.J. \& Cavalli-Sforza, L.L. 1984: The Neolithic transition and the genetics of populations in Europe. Princeton University Press, Princeton.

Antolín, F.; Buxó, R.; Jacomet, S.; Navarrete, V. \& SAÑA, M. 2014: An integrated perspective on farming in the early Neolithic lakeshore site of La Draga (Banyoles, Spain). Environmental Archaeology 19(3): 241-255.

Araújo, A.C.; Moreno-García, M. \& Gabriel, S. 2014: Para além de Toledo: outros dados, novas revisões e algumas reflexões sobre o Mesolítico Antigo do litoral da Estremadura. Revista Portuguesa de Arqueologia 17: 5-34.

Argant, T.; Thomas, R. \& Morris, J. 2013: Absent/ reduced hypoconulids in mandibular third molars amongst domestic cattle in north-west Europe: a preliminary investigation and some Speculations. $5^{\text {th }}$ International Conference of the ICAZ Animal Palaeopathology Working Group Osteoarchaeological Research Laboratory, University of Stockholm, Sweden. 31 May - 2 June 2013. https://animalpalaeopathologywg.files.wordpress.com/2013/06/mh3rdmolar.pdf.

Arnaud, J.M. 1993: O povoado calcolítico de Porto Torrão (Ferreira do Alentejo): síntese das investigações realizadas. Vipasca 2: 41-60.

Audoin-Rouzeau, F. 1995: Compter et mesurer les os animaux. Pour une histoire de l'élevage et de l'alimentation en Europe de l'Antiquité aux Temps Modernes. Histoire et Mesure 10: 277-312.

BADOux, D.M. 1964: Some remarks on size trends in mammalian evolution of the Holocene in Sumatra, with some additional notes on the Sampung fauna from Java. Säugetierkunde Mitteilungen 12: 1-12. 
Bate, D.M.A. 1903: Preliminary note on the discovery of a pigmy elephant in the Pleistocene of Cyprus. Proceedings of the Royal Society 73: 498-500.

- 1906: The pigmy Hippopotamus of Cyprus. Geological Magazine December V, 3: 241-245.

Bergmann, C. 1847: Ueber die Verhältnisse der Wärmeökonomie der Thiere zu ihrer Grösse. Göttingen Studien 3: 595-708.

Bernabeu, J.; García Puchol, O.; Pardo, S.; Barton, M. \& McClure, S.B. 2014: Socioecological dynamics at the time of Neolithic transition in Iberia. Environmental Archaeology 19: 214-225.

BIBI, F. 2013: A multi-calibrated mitochondrial phylogeny of extant Bovidae (Artiodactyla, Ruminantia) and the importance of the fossil record to systematic. BMC Evolutionary Biology 13:166. http://www. biomedcentral.com/1471-2148/13/166 .

Boekschoten, G.J. \& SondaAr, P.Y. 1972: On the fossil mammalia of Cyprus. Koninklijke Nederlandse Akademie Wetenschappen. Proceedings, Series B, 75: 306-338.

Boessneck, J. 1969: Osteological differences between sheep (Ovis aries Linné) and goat (Capra hircus Linné). In: Brothwell, D. \& Higgs, E.S. (eds.): Science in archaeology: 331-58. Thames and Hudson, London. $2^{\mathrm{a}}$ ed.

Boessneck, J.; Müller, H.-H. \& Teichert, M. 1964: Osteologische Unterscheidungsmerkmale zwischen Schaf (Ovis aries Linné) und Ziege (Capra hircus Linné). Kühn-Archiv 78: 1-129.

BosERUP, E. 1965: The conditions of agricultural growth: the economics of agrarian change under population pressure. George Allen and Unwin, London.

BRAIN, C.K. 1967: Hottentot food remains and their bearing on the interpretation of fossil bone assemblages. Scientific papers of the Namib Desert Research Institute 32: 1-11.

Bunch, T.D.; Foote, W.C. \& Spillett, J.J. 1976: Translocations of acrocentric chromosomes and their implications in the evolution of sheep (Ovis). Cytogenetics and Cell Genetics 17: 122-136.

BuRKE, J.F. 1837: British husbandry; exhibiting the farming practice in various parts of the United Kingdom. Vol II. Baldwin and Cradock, London.

Cardoso, J.L. \& Detry, C. 2002: Estudo arqueozoológico dos restos de ungulados do povoado pré-histórico de Leceia (Oeiras). Estudos Arqueológicos de Oeiras 10: 131-182.

Carvalho, A.F. de 2003: A emergência do Neolítico no actual território português: pressupostos teóricos, modelos interpretativos e a evidência empírica. $O \mathrm{Ar}$ queólogo Português, Série IV, 21: 65-150.
Castaños, P.M ${ }^{a}$ 1987: Los carnívoros prehistóricos de Vizcaya. Kobie (Serie Paleoantropología) 16: 7-76.

- 1990: Los carnívoros de los yacimientos prehistóricos vascos. Munibe (Antropologia - Arkeologia) 42: 253258.

- 1991: Animales domésticos y salvajes en Extremadura. Origen y evolución. Badajoz. Revista de Estudios Extremeños 47: 9-67.

- 1994: Estudio de la fauna del Cerro I de "Los Castillejos" (Fuente de Cantos, Badajoz). Norba 14: 11-46.

- 1995: Revisión de las primeras fechas de domesticación en el país vasco. Jornadas sobre Neolítico y Calcolítico (2. 1993. Bilbao) Sociedad de Estudios Vascos. Cuadernos de Sección. Prehistoria-Arqueología 6: 135-140.

- 2004: Estudio arqueozoológico de los macromamíferos del neolítico de la Cueva de Chaves (Huesca). Saldvie 4: 125-171.

Castaños, P.M ${ }^{\mathrm{a}}$; Pérez-Hidalgo, T. De; Ortiz Menéndez, J.E.; Montes Barquín, R.; Muñoz Fernández, E.; Morlote Expósito, J.M.; Santamaría Santamaría, S. \& Castaños De La Fuente, J. 2012: Yacimiento paleontológico de la vertiente sur de Peña Cabarga-pico del Castillo (Medio Cudeyo, Cantabria). Kobie. Paleoantropologia 31: 5-20.

Cebrià, A.; Xavier Oms, F.; Fontanals, M.; Rodríguez-Hidalgo, A.; Martín, P.; Soto, M.; Morales, J.I. \& Vergès, J.M ${ }^{\text {a }}$ 2014: Nuevos datos para el Neolítico antiguo en el nordeste de la Península Ibérica procedentes de la Cova del Toll (Moià, Barcelona) y de la Cova de la Font Major (L'Espluga de Francolí, Tarragona). Trabajos de Prehistoria 71(1): 134-145.

Chessa, B.; Pereira, F.; Arnaud, F.; Amorim, A.; Goyache, F.; Mainland, I.; Kao, R.R.; Pemberton, J.m.; Beraldi, D.; Stear, M.; Alberti, A.; Pittau, M.; Iannuzzi, L.; Banabazi, M.H.; Kazwali, R.; Zhang, Y.-P.; ArranZ, J.J.; Ali, B.A.; Wang, Z.; Uzun, M.; Dione, M.; Olsaker, I.; Holm, L.-E.; SaArma, U.; Ahmed, S.; Marzanov, N.; Eythorsdottir, E.; Holland, M.J.; Ajmone-Marsan, P.; Bruford, M.; Kantanen, J.; Spencer, T.E. \& Palmarini, M. 2009: Revealing the history of sheep domestication using retrovirus integrations. Science 324 (5926): 532-536.

Clutton-Brock, J. 1969: Carnivore remains from the excavations $\mathrm{f}$ the Jericho Tell. In: Ucko, P. \& Dimbleby, G. (eds.): The domestication and exploitation of plants and animals: 337-345. Duckworth, London.

- 1981: Domesticated animals from early times. British Museum (Natural History), London.

Cockram, J.; Jones, H.; Leigh, F.J.; O'sullivan, D.; Powell, W.; Laurie, D.A. \& Greenland, A.J. 2007: Control of flowering time in temperate cereals: genes, 
domestication, and sustainable productivity. Journal of Experimental Botany 58(6): 1231-1244.

Collette, B.B. 1999: Pomatomidae. Bluefishes. In: Karpenter, K.E. \& Niem, V.H. (eds.): FAO Species Identification Guide for Fishery Purposes. FAO, Rome.

Colominas, L.; Schlumbaum, A. \& Saña, M. 2013: The impact of the Roman Empire on animal husbandry practices: study of the changes in cattle morphology in the north-east of the Iberian Peninsula through osteometric and ancient DNA analyses. Archaeological and Anthropological Sciences; DOI 10.1007/s12520013-0116-9.

Coltman, D.W.; O’donoghue, P.; Jorgenson, J.T.; HogG, J.t.; Strobeck, C. \& Festa-Bianchet, M. 2003: Undesirable evolutionary consequences of trophy hunting. Nature 426: 655-658.

Corbera, J.; Sabatés, A. \& García-Rubies, A. 1998: Peces de Mar de la Península Ibérica. Planeta, Barcelona.

DARWIN, C.R. 1885: The variation of animals and plants under domestication. $2^{\text {nd }}$ ed. John Murray, London.

DAvis, S.J.M. 1981: The effects of temperature change and domestication on the body size of Late Pleistocene to Holocene mammals of Israel. Paleobiology 7: 101-114.

- 1985: A preliminary report on the fauna from Hatoula: a Natufian-Khiamian (PPNA) site near Latroun, Israel. In: Lechevallier, M. \& Ronen, A. (eds.): Le site Natoufien-Khiamien de Hatoula prés de Latroun, Israel : 71-98. Cahiers du Centre de Recherche Français de Jerusalem 1. Association Paléorient, Paris.

- 1992: A rapid method for recording information about mammal bones from archaeological sites. Historic Buildings and Monuments Commission, Ancient Monuments Laboratory report 19/92. London.

- 1996: Measurements of a group of adult female Shetland sheep skeletons from a single flock: a baseline for zooarchaeologists. Journal of Archaeological Science 23: 593-612.

- 2000: The effect of castration and age on the development of the Shetland sheep skeleton and a metric comparison between bones of males, females and castrates. Journal of Archaeological Science 27: 373-390.

- 2002: The mammals and birds from the Gruta do Caldeirão, Portugal. Revista Portuguesa de Arqueologia 5: 29-98.

- 2005: Why domesticate food animals? Some zoo-archaeological evidence from the Levant. Journal of Archaeological Science 32: 1408-1416.

- 2008: Zooarchaeological evidence for Moslem and Christian improvements of sheep and cattle in Por- tugal. Journal of Archaeological Science 35(4): 9911010 .

- 2016: Hacia una distinción métrica entre los astrágalos de oveja y cabra. In: Lloveras, L1.; Rissech, C.; Nadal, J. \& Fullola, J.M. (eds.): What bones tell us. El que ens expliquen els ossos: 35-58. Monografies del SERP 12. Universitat de Barcelona, Barcelona.

- 2017: Towards a metrical distinction between sheep and goat astragali. In: Rowley-Conwy, P.; Serjeantson, D. \& Halstead, P. (eds.): Economic zooarchaeology: studies in hunting, herding and early agriculture: 50-82. Oxbow Books, Oxford.

DAvis, S.J.M. \& BeCKeTT, J. 1999: Animal husbandry and agricultural improvement: the archaeological evidence from animal bones and teeth. Rural History: Economy, Society, Culture 10: 1-17.

Davis, S.J.M. \& Detry, C. 2013: Crise no mesolítico: evidências zooarqueológicas. In: Arnaud, J.M.; Martins, A. \& Neves, C. (eds.): Arqueologia em Portugal - 150 Anos: 297-309. Associação dos Arqueólogos Portugueses, Lisboa.

Davis, S.J.M.; Gonçalves, M.-J. \& Gabriel, S. 2008: Animal remains from a Moslem period $/ 12^{\text {th }} / 13^{\text {th }}$ century AD) lixeira (garbage dump) in Silves, Algarve, Portugal. Revista Portuguesa de Arqueologia 11(1): 183-258.

Davis, S.J.M. \& Mataloto, R. 2012: Animal remains from Chalcolithic São Pedro (Redondo, Alentejo): evidence for a crisis in the Mesolithic. Revista Portuguesa de Arqueologia 15: 47-85.

Davis, S.J.M. \& Moreno García, M. 2007: Of metapodials, measurements and music - eight years of miscellaneous zooarchaeological discoveries at the IPA, Lisbon. O Arqueólogo Português, Série IV, 25: 9-165.

Davis, S.J.M. \& PAYNE, S. 1993: A barrowful of cattle skulls. Antiquity 67: 12-22.

Davis, S.J.M; Svensson, E.M.; Albarella, U.; Detry, C.; Götherström, A.; Pires, A.E. \& Ginja, C. 2012: Molecular and osteometric sexing of cattle metacarpals: a case study from 15 th century AD Beja, Portugal. Journal of Archaeological Science 39(5): 1445-1454.

DAVIS, S.J.M. \& VILHENA, J. 2017: Animal remains from Iron Age and Roman Odemira, Portugal. Archaeofauna 26: 199-217.

Degerbøl, M. 1963: Prehistoric cattle in Denmark and adjacent areas. In: Mourant, A.E. \& Zeuner, F.E. (eds.): Man and cattle: Proceedings of a symposium on domestication at the Royal Anthropological Institute 24-26 May 1960: 69-79. Occasional Paper no. 18 of the Royal Anthropological Institute, London.

Degerbøl, M. \& Fredskild, B. 1970: The Urus (Bos primigenius Bojanus) and Neolithic domesticated cattle

Archaeofauna 27 (2018): 93-172 
(Bos taurus domesticus Linné) in Denmark with a revision of Bos-remains from the kitchen middens: zoological and palynological investigations. Det Kongelige Danske Videnskabernes Selskab Biologiske Skrifter, No. 17, 1. Munksgaard, København.

Detry, C. 2007: Paleoecologia e Paleoeconomia do Baixo Tejo no Mesolítico Final: O contributo do estudo dos mamíferos dos concheiros de Muge. Unpublished $\mathrm{Ph}$.D. dissertation. Universidade Autónoma de Lisboa e Universidade de Salamanca.

Detry, C. \& CARdoso, J.L. 2010: On some remains of dog (Canis familiaris) from the Mesolithic shell-middens of Muge, Portugal. Journal of Archaeological Science 37: 2762-2774.

Dixon, J.E. \& Renfrew, C. 1973: The source of the Franchthi obsidians. Hesperia 42: 82-83.

DrIESCH, A. VON DEn 1976: A guide to the measurement of animal bones from archaeological sites. Peabody Museum Bulletin 1. Harvard University Press, Cambridge, Mass.

Driesch, A. von den \& Boessneck, J. 1976: Die Fauna vom Castro do Zambujal (Fundmaterial der Grabungen von 1966 bis 1973 mit Ausnahme der Zwingerfunde). In: Driesch, A. von den \& Boessneck, J. (eds.): Studien über frühe Tierknochenfunde von der Iberischen Halbinsel 5: 4-129. Institut für Palaeoanatomie, Domestikationsforschung und Geschichte der Tiermedizin der Universität München. Deutsches Archäologisches Institut Abteilung Madrid. München.

Edwards, C.J.; Bollongino, R.; Scheu, A.; Chamberlain, A.; Tresset, A.; Vigne, J.-D.; Baird, J.F.; LARson, G.; Ho, S.Y.W.; Heupink, T.H.; Shapiro, B.; Freeman, A.R.; Thomas, M.G.; Arbogast, R.-M.; Arndt, B.; Bartosiewicz, L.; Benecke, N.; Budja, M.; Chaix, L.; Choyke, A.,.; Coqueugniot, E.; DöHle, H.-J.; Göldner, H.; Hartz, S.; Helmer, D.; Herzig, B.; Hongo, H.; Mashrour, M.; Özdogan, M.; Pucher, E.; Roth, G.; Schade-Lindig, S.; Schmölcke, U.; SchultING, R.J.; Stephan, E.; Uerpmann, H.-P.; Vörös, I.; Voytek, B.; Bradley, D.G. \& Burger, J. 2007: Mitochondrial DNA analysis shows a Near Eastern Neolithic of European aurochs origin for domestic cattle and no indication of domestication. Proceedings of the Royal Society B 274: 1377-1385.

EIsENMAnN, V. 1981: Etude des dents jugales inferieures des Equus (Mammalia, Perissodactyla) actuels et fossiles. Montpellier. Palaeovertebrata 10: 127-226.

Figueiredo, I.M. \& Santos, A.M.P. 1989: Reproductive biology of Sardina pilchardus (Walb.): seasonal maturity evolution (1986 to 1988). ICES CM 1989/H:40.

FLANNERY, K.V. 1969: Origins and ecological effects of early domestication in Iran and the Near East. In:
Ucko, P.J. \& Dimbleby, G.W. (eds.): The domestication and exploitation of plants and animals: 73-100. Duckworth, London.

Forsyth Major, C.I. 1902: On the pygmy hippopotamus from the Pleistocene of Cyprus. Proceedings of the Zoological Society, London 2: I, 238-9; II, 107-12.

FORT, J. 2015: Demic and cultural diffusion propagated the Neolithic transition across different regions of Europe. Journal of the Royal Society interface 12: 20150166 http://dx.doi.org/10.1098/rsif.2015.0166.

Froese, R. \& Pauly, D. (eds.) 2010: FishBase. World Wide Web electronic publication. www.fishbase.org, version $(11 / 2010)$.

GABRIEL S. 2011: A exploração dos recursos ictíicos. In: Araújo, A.C. (ed.): O concheiro de Toledo no contexto do Mesolítico inicial do Litoral da Estremadura. Trabalhos de Arqueologia 53: 127-144. IGESPAR, Lisboa.

- 2015: La ictiofauna del Holoceno Inicial y Medio de Portugal: Implicaciones tafonómicas, ecológicas y culturales. Universidad Autónoma de Madrid. Unpublished PhD Thesis.

Gabriel, S.; Prista, N. \& Costa, M.J. 2012: Estimating meagre (Argyrosomus regius) size from otoliths and vertebrae. Journal of Archaeological Science 39(9): 2859-2865.

Gautier, A. 1987: Taphonomic groups: How and Why? Archaeozoologia 1(2): 47-52.

Grant, A. 1982: The use of tooth wear as a guide to the age of domestic ungulates. In: Wilson, B.; Grigson, C. \& Payne, S. (eds.): Ageing and sexing animal bones from archaeological sites: 91-108. B.A.R. (British Series) 109. Oxford.

Grau-SologestoA, I. 2015: Livestock management in Spain from Roman to post-medieval times: a biometrical analysis of cattle, sheep/goat and pig. Journal of Archaeological Science 54: 123-134.

Guiry, E.; Hillier, M.; Boaventura, R.; Silva, A.; Oosterbeek, L.; Tomé, T.; Valera, A.; Cardoso, J.L.; Hepburn, J.C. \& Richards, M. 2016: The transition to agriculture in south-western Europe: New isotopic insights from Portugal's Atlantic coast. Antiquity 90 (351): 604-616.

Harris, A.H. \& Mundel, P. 1974: Size reduction of bighorn sheep (Ovis canadensis) at the close of the Pleistocene. Journal of Mammalogy 55: 678-680.

Hendey, Q.B. 1974: The late Cenozoic carnivores of the south-western Cape Province. Annals of the South African Museum 63: 1-369.

Hiendleder, S.; Kaupe, B.; Wassmuth, R. \& Janke, A. 2002: Molecular analysis of wild and domestic sheep 
questions current nomenclature and provides evidence for domestication from two different subspecies. Proceedings of the Royal Society London B. 269: 893-904.

Higham, C.F.W. 1968: Size trends in prehistoric European domestic fauna, and the problem of local domestication. Acta Zoologica Fennica 120: 3-21.

Hofmanová, Z.; Kreutzer, S.; Hellenthal, G.; Sell, C.; Diekmann, Y.; Díez Del Molino, D.; Dorp, L. Van; López, S.; Kousathanas, A.; Link, V.; Kirsanow, K.; Cassidy, L.M.; Martiniano, R.; Strobel, M.; Scheu, A.; Kotsakis, K.; Halstead, P.; Triantaphyllou, S.; Kyparissi-Apostolika, N.; Urem-Kotsou, D.; Ziota, C.; Adaktylou, F.; Gopalan, S.; Bobo, D.M.; WinKELBACH, L.; BlÖChER, J.; UNTERLÄNDER, M.; LEUENBerger, C.; ÇıllngiroĞlu, Ç; Horejs, B.; Gerritsen, F.; Shennan, S.J.; Bradley, D.J.; Currat, M.; VeeraMah, K.R.; Wegmann, D.; Thomas, M.G.; PapageorGopoulou, C. \& Burger, J. 2016: Early farmers from across Europe directly descended from Neolithic Aegeans. Proceedings of the National Academy of Sciences 113(25): 6886-6891.

Hsü, K.J.; Ryan, W.B.F. \& CitA, M.B. 1973: Late Miocene desiccation of the Mediterranean. Nature 242: 240-244.

Iborra Eres, P. \& Martínez Valle, R. 2009: La fauna de los niveles neolíticos de la Cova de les Cendres. In: Bernabeu Aubán, J. \& Molina Balaguer, Ll. (eds.): La Cova de les Cendres - Alicante: 149-162. MARQ Serie Mayor, núm. 6. Museo Arqueológico de Alicante, Alicante.

Isern, N.; Zilhão, J.; Fort, J. \& Ammerman, A.J. 2017: Modeling the role of voyaging in the coastal spread of the Early Neolithic in the West Mediterranean. Proceedings of the National Academy of Science. www.pnas.org/cgi/doi/10.1073/pnas.1613413114

KLEIN, R.G. 1976: The fossil history of Raphicerus H. Smith, 1827 (Bovidae, Mammalia) in the Cape biotic zone. Annals of the South African Museum 71: 169191.

Koch, P.L. \& Barnosky, A.D. 2006: Late Quaternary Extinctions: State of the Debate. Annual Review of Ecology, Evolution and Systematics 37: 215-50.

Kurtén, B. 1965: Carnivora of the Palestine caves. Acta Zoologica Fennica 107: 1-74.

Larson, G.; Dobney, K.; Albarella, U.; Fang, M.; Matisoo-Smith, E.; Robins, J.; Lowden, S.; Finlayson, H.; Brand, T.; Willerslev, E.; Rowley-Conwy, P.; Andersson, L. \& Cooper, A. 2005: Worldwide phylogeography of wild boar reveals multiple centers of pig domestication. Science 307: 1618-1621.

Le Gall, O.; Straus, L.G.; Vierra, B .J .\& Altuna, J. 1992: Ichthyofaunas and Seasonality at Vidigal (Alentejo,
Portugal). Mesolithic Miscellany 13(2): 13-18.

Le Gall, O.; Altuna, J. \& Strauss, L.G. 1994: Les faunes mésolithique et néolithique de Vidigal (Alentejo, Portugal). Archaeozoologia 7(1): 59-72.

LeNTACKer, A. 1986: Preliminary results of the fauna of Cabeço da Amoreira and Cabeço da Arruda (Muge, Portugal). Trabalhos de Antropologia e Etnologia 26(1-4): 9-26.

- 1994: Fish remains from Portugal: preliminary analysis of the Mesolithic shell-midden sites of Cabeco da Amoreira and Cabeco da Arruda. In: Van Neer, W. (ed.): Fish exploitation in the past. Annales du Musée Royal de l'Afrique Centrale, Sciences Zoologiques 274: 263-271.

LóPEz-Doriga, I. \& Simões, T. 2015: Los cultivos del Neolítico Antiguo de Sintra: Lapiás das Lameiras y São Pedro de Canaferrim: resultados preliminaries. In: Gonçalves, V.S.; Diniz, M. \& Sousa, A.C. (eds.): Actas $5^{\circ}$ Congresso do Neolítico Peninsular Actas: 96-105. Câmara Municipal de Cascais, Lisboa.

Lubell, D.; Jackes, M.; Schwarcz, H.; Knyf, M. \& MeICKLEJOHN, C. 1994: The Mesolithic-Neolithic transition in Portugal: isotopic and dental evidence of diet. Journal of Archaeological Science 21(2): 201-16.

Martín, P.; Rosell, J. \& Vergès, J.M. 2009: La gestión de los recursos faunísticos durante el Neolítico en la Sierra de Atapuerca (Burgos): los niveles 19 y 20 de la Cueva del Mirador. Trabajos de Prehistoria 66(2): 77-79. doi: 10.3989/tp.2009.09024.

Martins, H.; Xavier, O.F.; Pereira, L.; Pike, A.w.g.; Rowsell, K. \& ZILHÃo, J. 2015: Radiocarbon Dating the Beginning of the Neolithic in Iberia: New Results, New Problems. Journal of Mediterranean Archaeology 28: 105-131.

Matolsci, J. 1970: Historische Erforschung der Körpergrösse des Rindes auf Grund von ungarischem Knochenmaterial. Zeitschrift für Tierzüchtung und Züchtungsbiologie 87: 89-137.

Mendes, P.; Jordão, P. \& Simões, T. 2005: Lapiás das Lameiras, Sintra: relatório da escavação realizada em 2004 [unpublished].

MıŁкоwsкi, L. \& WósJcik, J.M. 1984: Structure of wild boar harvest in the Białowieża Primeval Forest. Acta Theriologica 29: 337-347.

Morales, A. \& Rosenlund, K. 1979: Fish bone measurements. An attempt to standarize the measuring of fish bones from Archaeological sites. Steenstrupia, Copenhagen.

Moreno-García, M. \& SousA, A.C. 2013: A exploração de recursos faunísticos no Penedo do Lexim (Mafra) no Neolítico Final. In: Gonçalves, V.S.; Diniz, M. \& Sousa, A.C. (eds.): Actas $5^{\circ}$ Congresso do Neolítico 
Peninsular: 67-76. Câmara Municipal de Cascais, Lisboa.

MunRo, N.D. 2001: A prelude to agriculture: game use and occupation intensity during the Natufian period in the southern Levant. PhD dissertation. Department of Anthropology, University of Arizona, Tucson.

Nadler, C.F.; Korobitsina, K.V.; Hoffmann, R.S. \& Vorontsov, N.N. 1973: Cytogenetic differentiation, geographic distribution, and domestication in $\mathrm{Pa}-$ laearctic sheep (Ovis). Zetschrift für Saugetierkunde 38: 109-25.

O'Connor, T.P. 2000: The archaeology of animal bones. Sutton Publishing, Stroud.

Olsen, A.M. 1999: Using Sharks. In: Stevens, J.D. (ed.): Sharks: 206-213. Checkmark Press, New York.

Orlando, L.; Mashkour, M.; Burke, A.; Douady, C.J.; Eisenmann, V. \& HänNi, C. 2006: Geographic distribution of an extinct equid (Equus hydruntinus: Mammalia, Equidae) revealed by morphological and genetical analyses of fossils. Molecular Ecology 15: 2083-2093.

PAYNe, S. 1969: A metrical distinction between sheep and goat metacarpals. In: Ucko, P.J. \& Dimbleby, G.W. (eds.): The domestication and exploitation of plants and animals: 295-305. Duckworth, London.

- 1972: Partial recovery and sample bias. In: Higgs, E.S. (ed.): Papers in economic prehistory: 49-64. Cambridge University Press, Cambridge.

- 1973: Kill-off patterns in sheep and goats: the mandibles from Aşvan Kale. Anatolian Studies 23: 281-303.

- 1985: Morphological distinctions between the mandibular teeth of young sheep, Ovis, and goats, Capra. Journal of Archaeological Science 12: 139-147.

- 1987: Reference codes for wear states in the mandibular cheek teeth of sheep and goats. Journal of Archaeological Science 14: 609-614.

Payne, S. \& Bull, G. 1988: Components of variation in measurements of pig bones and teeth, and the use of measurements to distinguish wild from domestic pig remains. Archaeozoologia 2: 27-65.

Pedrosa, S.; Uzun, M.; Arranz, J.-J.; Gutiérrez-Gil, B.; Primitivo, F.S. \& BAYÓN, Y. 2005: Evidence of three maternal lineages in near eastern sheep supporting multiple domestication events. Proceedings of the Royal Society B 272: 2211-2217.

PÉRez Ripoll, M. 1980: La fauna de vertebrados. In: Marti Oliver (ed.): Cova de l'Or (Beniarrés-Alicante): 193-255. Vol II. Servicio de Investigación Prehistórica, Serie de Trabajos Varios, Núm. 65. Valencia.

- 2006: Estudio arqueozoológico del Abric de la Falguera (Alcoi, Alacant). In: García Puchol, O. \& Aura
Tortosa, J.E. (coords.): El Abric de la Falguera (Alcoi, Alacant) 8.000 años de ocupación humana en la cabecera del río de Alcoi: 120-157. Caja de Ahorros del Mediterráneo, Ayuntamiento de Alcoy, Alicante.

Peters, J.; Driesch, A. von den \& Helmer, D. 2005: The upper Euphrates-Tigris basin: cradle of agro-pastoralism?. In: Vigne, J.-D.; Peters, J. \& Helmer, D. (eds.): The first steps of animal domestication: 96-124. $9^{\text {th }}$ ICAZ Conference, Durham 2002. Oxbow books, Oxford.

Pinhasi, R.; Fort, J. \& Ammerman, A.J. 2005: Tracing the origin and spread of agriculture in Europe. PloS Biology 3(12): 0001-0009.

Popkin, P.R.W.; Baker, P.; Worley, F.; PAyne, S. \& HamMON, A. 2012: The Sheep Project (1): determining skeletal growth, timing of epiphyseal fusion and morphometric variation in unimproved Shetland sheep of known age, sex, castration status and nutrition. Journal of Archaeological Science 39: 1775-1792.

Rainsford, C.; O'Connor, T. \& Miracle, P. 2014: Fishing in the Adriatic at the Mesolithic-Neolithic transition: evidence from Vela Spila, Croatia. Environmental Archaeology 19(3): 311-320.

Randi, E.; Fusco, G.; Lorenzini, R.; Toso, S \& \& Tosi, G. 1991: Allozyme divergence and phylogenetic relationships among Capra, Ovis and Rupicapra (Artiodactyla, Bovidae). Heredity: 67(3): 281-286.

REED, C.A. 1961: Osteological evidences for prehistoric domestication in southwestern Asia. Zeitschrift fur Tierzuchtung und Zuchtungsbiologie 76: 31-38.

RegÀlia, E. 1907: Sull'Equus (Asinus) hydruntinus Regalia della grotta di Romanelli (Castro, Lecce). Archivio per l'Antropologia e l'Etnologia 37: 375-390.

Richards, M.P.; Schulting, R.J.\& Hedges, R.E.M. 2003: Sharp shift in diet at onset of Neolithic. Nature 425: 366.

Rick, T.C. \& Erlandson, J.M. 2002: Evaluating the Economic Significance of Sharks, Skates, and Rays (Elasmobranchs) in Prehistoric Economies. Journal of Archaeological Science 29: 111-122.

Rowley-Conwy, P. 1984: The laziness of the short-distance hunter: the origins of agriculture in western Denmark. Journal of Anthropological Archaeology 3: 300-324.

- 1992: The early Neolithic animal bones from Gruta do Caldeirão. In: Zilhão, J. 1992: Gruta do Caldeirão O Neolítico Antigo: 231-257. Instituto Português do Património Arquitectónio e Arqueológico. Trabalhos de Arqueologia 6.

Rowley-Conwy, P.; Gourichon, L.; Helmer, D. \& Vigne, J.-D. 2013: Early Domestic Animals in Italy, Istria, the Tyrrhenian Islands, and Southern France. In: Colledge, S.; Conolly, J.; Dobney, K.; Manning, K. 
\& Shennan, S. (eds.): The Origins and Spread of Domestic Animals in Southwest Asia and Europe. Left Coast Press, Walnut Creek. California.

RufF, C.B. 1994: Morphological adaptation to climate in modern and fossil hominids. Yearbook of Physical Anthropology 37: 65-107.

SAÑA, M. 2013: Domestication of Animals in the Iberian Peninsula. In: Colledge, S. et al. (eds.): The Origins and Spread of Domestic Animals in Southwest Asia and Europe: 195-221. Left Coast Press, Inc.

Schultz, C.B. 1976: Climatic changes and large mammal populations in the great plains of North America during the late Quaternary times. Symposium on Quaternary Glaciations in the Northern Hemisphere (International Geological Correlation Program IUGS-UNESCO) handout.

SERJEAnTSOn, D. 2014: Survey of animal remains from southern Britain finds no evidence for continuity from the Mesolithic period. Environmental Archaeology 19(3): 256-262.

Simões, T. 2004: Lapiás das Lameiras, Sintra: relatório da escavação realizada em 2002 [unpublished].

Sousa, A.C.; Monge Soares, A.; Miranda, M.; Queiroz, P.F. \& Leeuwataden, W. Van 2004: São Julião; Núcleo $C$ do Concheiro Pré-Histórico. Mafra, Câmera Municipal de Mafra, Cadernos de Arqueologia de Mafra 2.

SteELE, T.E. 2002: Red deer: their ecology and how they were hunted by late Pleistocene hominids in Western Europe. PhD dissertation, Stanford University, California.

Stehlin, H.G. \& Graziosi, P. 1935: Ricerche sugli Asinidi fossili d'Europa. Mémoires de la Société Paléontologique Suisse 56: 1-73.

TAuBer, H. 1981: ${ }^{13} \mathrm{C}$ evidence for dietary habits of prehistoric man in Denmark. Nature 292: 332-333.

TCHERNOv, E. 1968: Succession of rodent faunas during the Upper Pleistocene of Israel. Paul Parey, Hamburg.

Thomas, R.; Holmes, M. \& Morris, J. 2013: "So bigge as bigge may be": tracking size and shape change in domestic livestock in London (AD 1220-1900). Journal of Archaeological Science 40(8): 3309-3325.

Tresset, A. \& Vigne, J.-D. 2011: Last hunter-gatherers and first farmers of Europe. Les derniers chasseurs-cueilleurs et les premiers agriculteurs en Europe. Comptes Rendus Biologies 334: 182-189.

Uerpmann, H.-P. 1979: Probleme der Neolithisierung des Mittelmeerraums. Tübinger Atlas des Vorderen Orients, B. 28. Ludwig Reichert, Wiesbaden.

Valente, M.J. 2008: As últimas sociedades de caçadores-recolectores no Centro e Sul de Portugal (10.000

archaeofauna 27 (2018): 93-172
- 6.000 anos BP): aproveitamento dos recursos animais. Tese de Doutoramento (policopiada). Faculdade de Ciências Humanas e Sociais, Universidade do Algarve. Faro.

- 2013: Arqueozoologia da Barca do Xerez de Baixo. In: Araújo, A.C. \& Almeida, F. (eds.): Barca do Xerez de Baixo; um testemunho invulgar das últimas comunidades de caçadores-recolectores do Alentejo interior: 245-304. EDIA - Empresa de desenvolvimento e infra-estruturas do Alqueva DRCALEN - Direcção Regional de Cultura do Alentejo. Memórias d'Odiana $2^{\mathrm{a}}$ Série. Estudos Arqueológicos do Alqueva.

Vigne, J.-D. 2011: The origins of animal domestication and husbandry: A major change in the history of humanity and the biosphere. Comptes Rendus Biologies 334: 171-181 doi:10.1016/j.crvi.2010.12.009.

- 2014: The origins of mammals on the Mediterranean islands as an indicator of early voyaging. Eurasian Prehistory 10(1-2): 45-56.

Vigne, J.-D.; Carrère, I.; Briois, F. \& Guilaine, J. 2011: The Early Process of Mammal Domestication in the Near East; New Evidence from the Pre-Neolithic and Pre-Pottery Neolithic in Cyprus. Current Anthropology 52: Supplement 4: S255-271.

Whitehead, P.J.P.; Bauchot, M.L.; Hureau, J.C.; NielSEN, J. \& ToRTonse, E. 1989: Fishes of the Northeastern Atlantic and the Mediterranean. UNESCO, Paris.

Wright, E. \& Viner-Daniels, S. 2015: Geographical variation in the size and shape of the European aurochs (Bos primigenius). Journal of Archaeological Science 54: 8-22.

ZEDER M.A. \& LAPHAM, H.A. 2010: Assessing the reliability of criteria used to identify postcranial bones in sheep, Ovis, and goats, Capra. Journal of Archaeological Science 37: 2887-2905.

Zeuner, F.E. 1963: A history of domesticated animals. Hutchinson, London.

ZILHÃo, J. 2000: From the Mesolithic to the Neolithic in the Iberian península. In: Douglas Price, T. (ed.): Europe's first farmers: 144-182. Cambridge University Press, Cambridge.

- 2001: Radiocarbon evidence for maritime pioneer colonization at the origins of farming in west Mediterranean Europe. Proceedings of the National Academy of Sciences 98(24): 14180-14185.

- 2011: Time is on my side ... In: Hadjikoumis, A.; Robinson, E. \& Viner, S. (eds.): The Dynamics of Neolithisation in Europe: Studies in honour of Andrew Sherratt: 46-65. Oxbow books, Oxford. 
APPENDIX A. LAMEIRAS BONE MEASUREMENTS ASTRAGALUS

\begin{tabular}{|c|c|c|c|c|c|c|c|c|c|c|}
\hline Bone & Taxon & Period & Fus & GL & Bd & Dl & Notes & Sector & UE & Ambiente \\
\hline Astragalus & Bos & Late Chalcolithic & - & 638 & 387 & 346 & - & Sul & 3-IV & - \\
\hline Astragalus & Bos & Late Neolithic & - & - & 391 & - & $\mathrm{Dl}=33-34$ estimated & Sul & 63 & $\mathrm{H} 2-\mathrm{B}$ \\
\hline Astragalus & Bos & Late Neolithic & - & 607 & 370 & 338 & - & Sul & 78 & G3D \\
\hline Astragalus & Bos & Late Neolithic & - & 698 & 430 & 382 & all msmnts. approx. & Sul & 78 & $\mathrm{H} 3 \mathrm{C}$ \\
\hline Astragalus & Bos & Late Neolithic & - & 721 & 462 & 388 & Small aurochs? & Sul & 74 & $\mathrm{~L} 4 \mathrm{C}$ \\
\hline Astragalus & Bos & Evolved Early Neolithic & - & - & 420 & - & $\begin{array}{l}\mathrm{GLl}=\text { approx } .700 \mathrm{Bd}=\text { approx } \\
\mathrm{Dl}=380-390\end{array}$ & Sul & 103 & $\begin{array}{l}\mathrm{K} 4 \mathrm{D} / \mathrm{L} 4 \mathrm{C} / \\
\mathrm{L} 4 \mathrm{D}\end{array}$ \\
\hline Astragalus & Bos & Evolved Early Neolithic & - & 644 & 395 & 354 & - & Sul & 103 & $\mathrm{~L} 3 \mathrm{~B} / \mathrm{L} 3 \mathrm{D}$ \\
\hline Astragalus & $\begin{array}{l}\text { Capra } \\
\text { hircus }\end{array}$ & Early Neolithic & - & 300 & 187 & 155 & definite Capra & Sul & 100 & $\mathrm{~K} 3 \mathrm{C} / \mathrm{K} 3 \mathrm{~A}$ \\
\hline Astragalus & $\begin{array}{l}\text { Capra } \\
\text { hircus? }\end{array}$ & Late Neolithic & - & - & 163 & - & - & Sul & 73 & $\mathrm{~J} 3 \mathrm{D}$ \\
\hline Astragalus & $\begin{array}{l}\text { Capra } \\
\text { hircus? }\end{array}$ & Late Neolithic & - & - & 171 & - & $\mathrm{Bd}=$ approx & Sul & 63 & H3-D \\
\hline Astragalus & $\begin{array}{l}\text { Capra } \\
\text { hircus? }\end{array}$ & Evolved Early Neolithic & - & - & 175 & - & - & Sul & 107 & $\mathrm{~N} 4 \mathrm{C} / \mathrm{M} 4 \mathrm{D}$ \\
\hline Astragalus & $\begin{array}{l}\text { Capra } \\
\text { hircus? }\end{array}$ & Early Neolithic & - & - & 178 & 154 & $\mathrm{GLl}=284$ - estimated & - & $37-2$ & L20-L21 \\
\hline Astragalus & $\begin{array}{l}\text { Capra } \\
\text { hircus? }\end{array}$ & Early Neolithic & - & - & 181 & - & - & Sul & 53 & M3B \\
\hline Astragalus & Oryctolagus & Evolved Early Neolithic & - & 102 & - & - & - & Sul & 107 & N4C/M4D \\
\hline Astragalus & Oryctolagus & Evolved Early Neolithic & - & 109 & - & - & - & Sul & 107 & $\mathrm{~N} 4 \mathrm{C}$ \\
\hline Astragalus & Oryctolagus & Early Neolithic & - & 100 & - & - & - & JK17-18 & 39 & 7 \\
\hline Astragalus & Oryctolagus & Early Neolithic & - & 113 & - & - & - & M21 & 27 & 2 \\
\hline Astragalus & Oryctolagus & Mousterian & - & 112 & - & - & - & Sul & 136 & $\mathrm{~N} 4 \mathrm{~A}$ \\
\hline Astragalus & Ovis aries & Late Neolithic & - & 273 & 179 & 157 & - & Sul & 68 & M3C \\
\hline Astragalus & Ovis aries & Late Neolithic & - & 276 & - & 154 & $\mathrm{GLl}=$ approx & Sul & 71 & K4D \\
\hline Astragalus & Ovis aries & Late Neolithic & - & 289 & 178 & 157 & definite Ovis & Sul & 73 & $\mathrm{~J} 2 \mathrm{~A}$ \\
\hline Astragalus & Ovis aries & Late Neolithic & - & 291 & 186 & 167 & - & Corte E-O & UC4 II & M4 \\
\hline Astragalus & Ovis aries & Late Neolithic & - & 309 & 195 & 172 & definite Ovis & Corte E-O & $4 \mathrm{III}$ & $\mathrm{P} 4$ \\
\hline Astragalus & Ovis aries & Evolved Early Neolithic & - & 270 & 173 & 154 & - & Sul & 52 & $\mathrm{P} 4$ \\
\hline Astragalus & Ovis aries & Evolved Early Neolithic & - & 296 & 195 & 171 & - & Sul & 103 & $\mathrm{~K} 3 \mathrm{D} / \mathrm{K} 3 \mathrm{~B}$ \\
\hline Astragalus & Ovis aries & Evolved Early Neolithic & - & 311 & 203 & 174 & - & Sul & 52 & $\mathrm{P} 3 \mathrm{~B}$ \\
\hline Astragalus & Ovis aries & Early Neolithic & - & 273 & 186 & 160 & definite Ovis & E9 & $10-3$ & - \\
\hline Astragalus & Ovis aries & Early Neolithic & - & 292 & 186 & 163 & slightly burnt & Sul & 53 & L4D \\
\hline Astragalus & Ovis aries & Early Neolithic & - & 306 & 200 & 180 & definite Ovis & E9 & $10-6$ & - \\
\hline Astragalus & Ovis aries & Early Neolithic & - & 308 & 189 & 170 & - & L20/M20 & 26 & 5 \\
\hline Astragalus & Ovis aries & Early Neolithic & - & 313 & 199 & 174 & $\mathrm{Dl}=$ approx., definite Ovis & M21 & 27 & 2 \\
\hline Astragalus & Ovis aries & Early Neolithic & Juv & 275 & 169 & 154 & $\mathrm{Bd}=$ approx & L20 & 26 & 1 \\
\hline Astragalus & Ovis aries? & Late Neolithic & - & 234 & 150 & 136 & $\mathrm{Dl}=$ approx & Sul & 71 & L3B \\
\hline Astragalus & Ovis aries? & Late Neolithic & - & 253 & 174 & 144 & - & Sul & 78 & H3A \\
\hline Astragalus & Ovis aries? & Late Neolithic & - & 307 & 194 & 171 & - & Sul & 78 & $\mathrm{H} 3 \mathrm{~B}$ \\
\hline Astragalus & Ovis aries? & Evolved Early Neolithic & - & - & 180 & - & - & Sul & 52 & M4 \\
\hline Astragalus & Ovis aries? & Evolved Early Neolithic & - & 295 & 189 & 167 & - & Sul & 75 & $\mathrm{~K} 3 \mathrm{C}$ \\
\hline Astragalus & Ovis aries? & Evolved Early Neolithic & - & 297 & 196 & 167 & - & Sul & 103 & $\begin{array}{l}\mathrm{K} 4 \mathrm{D} / \mathrm{L} 4 \mathrm{C} / \\
\mathrm{L} 4 \mathrm{D}\end{array}$ \\
\hline Astragalus & Ovis aries? & Evolved Early Neolithic & - & 307 & 194 & 170 & - & Sul & 52 & N4 \\
\hline Astragalus & Ovis aries? & Early Neolithic & - & - & 195 & - & - & M20 & 26 & - \\
\hline Astragalus & Ovis aries? & Early Neolithic & - & 267 & 185 & 151 & - & M21 & 27 & 2 \\
\hline Astragalus & Ovis aries? & Early Neolithic & - & 298 & 188 & 172 & - & JK17-18 & 39 & 2 \\
\hline Astragalus & Ovis/Capra & Late Neolithic & - & 271 & 167 & 149 & - & Sul & 63 & - \\
\hline Astragalus & Ovis/Capra & Late Neolithic & - & 290 & 176 & 164 & $\mathrm{Bd}=$ approx & Sul & 71 & L4D \\
\hline Astragalus & Ovis/Capra & Late Neolithic & - & 294 & - & 168 & - & Sul & 68 & $\mathrm{~J} 2 \mathrm{~A}$ \\
\hline
\end{tabular}




\begin{tabular}{|c|c|c|c|c|c|c|c|c|c|c|}
\hline Bone & Taxon & Period & Fus & GL & Bd & DI & Notes & Sector & UE & Ambiente \\
\hline Astragalus & Ovis/Capra & Late Neolithic & - & 319 & 207 & 181 & $\mathrm{Dl}=$ approx & Sul & 68 & M4D \\
\hline Astragalus & Ovis/Capra & Evolved Early Neolithic & - & 264 & - & 148 & $\mathrm{Bd}=175-180$ damaged & Sul & 75 & M3A \\
\hline Astragalus & Ovis/Capra & Early Neolithic & - & & 166 & - & - & Sul & 53 & M4C \\
\hline Astragalus & Ovis/Capra & Early Neolithic & - & & 187 & - & - & $\mathrm{J}-\mathrm{K} / 17-18$ & 39 & 2 \\
\hline Astragalus & Ovis/Capra & Early Neolithic & - & 278 & 177 & 152 & Capra? & Sul & 53 & M3C \\
\hline Astragalus & Ovis/Capra & Early Neolithic & - & 283 & 182 & 166 & - & Sul & 53 & $\mathrm{P} 4 \mathrm{C}$ \\
\hline Astragalus & Ovis/Capra & Early Neolithic & - & 295 & 179 & 164 & - & Sul & 53 & $\mathrm{M} 3 \mathrm{C}$ \\
\hline Astragalus & Sus & Late Neolithic & - & 334 & - & - & - & Sul & 73 & K3B \\
\hline Astragalus & Sus & Late Neolithic & - & 376 & - & - & - & Sul & 73 & $\mathrm{~J} 2 \mathrm{~A}$ \\
\hline Astragalus & Sus & Late Neolithic & - & 382 & - & - & - & Sul & 74 & $\mathrm{~L} 4 \mathrm{C}$ \\
\hline Astragalus & Sus & Late Neolithic & - & 384 & - & - & - & Sul & 71 & L4D \\
\hline Astragalus & Sus & Late Neolithic & - & 423 & - & - & - & Sul & 68 & M4C \\
\hline Astragalus & Sus & Evolved Early Neolithic & - & 392 & - & - & - & Sul & 103 & L4C \\
\hline Astragalus & Sus & Evolved Early Neolithic & - & 400 & - & - & - & Sul & 103 & $\begin{array}{l}\mathrm{K} 4 \mathrm{D} / \mathrm{L} 4 \mathrm{C} / \\
\mathrm{L} 4 \mathrm{D}\end{array}$ \\
\hline Astragalus & Sus & Evolved Early Neolithic & - & 406 & - & - & - & Sul & 52 & P4N4 \\
\hline Astragalus & Sus & Evolved Early Neolithic & - & 432 & - & - & - & Sul & 107 & $\mathrm{~N} 3 \mathrm{~A} / \mathrm{N} 3 \mathrm{~B}$ \\
\hline Astragalus & Sus & Evolved Early Neolithic & - & 450 & - & - & - & Sul & 103 & $\mathrm{~L} 4 \mathrm{C}$ \\
\hline Astragalus & Sus & Early Neolithic & - & 378 & - & - & - & M20 & 26 & 3 \\
\hline Astragalus & Sus & Early Neolithic & - & 397 & - & - & - & - & 33 & E9/E10 \\
\hline Astragalus & Sus & Early Neolithic & - & 413 & - & - & - & $\mathrm{J} 17$ & 39 & 4 \\
\hline Astragalus & Sus & Early Neolithic & - & 443 & - & - & - & Sul & 53 & L4D \\
\hline Astragalus & Sus & Early Neolithic & - & 445 & - & - & - & E10 & $7 / 8$ & - \\
\hline Astragalus & Sus & Early Neolithic & - & 447 & - & - & - & Sul & 100 & $\mathrm{~K} 3 \mathrm{C} / \mathrm{K} 3 \mathrm{~A}$ \\
\hline
\end{tabular}

APPENDIX TABLE

Lameiras - measurements in tenths of a millimetre of the astragali. Key: taxa are Bos - Bos taurus/primigenius cattle/aurochs, Capra hircus goat, Oryctolagus cuniculus rabbit, Ovis aries sheep, Sus pig/wild boar. Measurements follow Driesch (1976). Approximate measurements are noted in the "notes" column. The lengths "GL" are taken up the lateral side. 
APPENDIX A. LAMEIRAS BONE MEASUREMENTS HUMERUS + TIBIA + FEMUR

\begin{tabular}{|c|c|c|c|c|c|c|c|c|c|c|c|c|}
\hline Bone & Taxon & Period & Fus & GL & Bd & Dd & BT & HTC & Notes & Sector & UE & Ambiente \\
\hline Femur & Lepus & Early Neolithic & $\mathrm{F}$ & - & 188 & - & - & - & - & JK17-18 & 39 & 8 \\
\hline Humerus & Bos & Late Neolithic & $\mathrm{F}$ & - & - & - & - & 319 & - & Sul & 73 & K3D \\
\hline Humerus & Capra hircus & Late Chalcolithic & $\mathrm{F}$ & - & - & - & 275 & 127 & BT = approx. & Sul & 4 & $\mathrm{~N} 3 \mathrm{~A}$ \\
\hline Humerus & Capra hircus & Late Neolithic & $\mathrm{Fv}$ & - & - & - & 259 & 119 & BT = approx. & Sul & 68 & M3B \\
\hline Humerus & Capra hircus & Early Neolithic & $\mathrm{Fv}$ & - & - & - & 258 & 131 & spongy, prob. juvenile & L20/M20 & 26 & 8 \\
\hline Humerus & Capra hircus? & Late Neolithic & $\mathrm{F}$ & - & - & - & - & 146 & - & Sul & 68 & $\mathrm{~J} 3 \mathrm{D}$ \\
\hline Humerus & Capreolus & Late Neolithic & $F$ & - & - & - & 241 & 143 & - & Sul & 73 & K3D \\
\hline Humerus & Felis silvestris & Early Neolithic & $\mathrm{F}$ & - & 180 & - & - & 57 & - & J17 & 39 & 4 \\
\hline Humerus & Lepus & Late Neolithic & $\mathrm{F}$ & - & 110 & - & - & 57 & - & Sul & 74 & $\mathrm{~J} 4 \mathrm{C}$ \\
\hline Humerus & Lepus & Early Neolithic & $\mathrm{F}$ & - & 106 & - & - & 57 & - & E9/E10 & 33 & - \\
\hline Humerus & Oryctolagus & Late Chalcolithic & $\mathrm{F}$ & - & 82 & - & - & 40 & - & Sul & 3 & L3A \\
\hline Humerus & Oryctolagus & Late Neolithic & $\mathrm{F}$ & - & - & - & - & 36 & - & Sul & 86 & G3B \\
\hline Humerus & Oryctolagus & Late Neolithic & $\mathrm{F}$ & - & - & - & - & 37 & - & Sul & 68 & M3B \\
\hline Humerus & Oryctolagus & Late Neolithic & $\mathrm{F}$ & - & 77 & - & - & 34 & - & Sul & 68 & $\mathrm{~K} 3 \mathrm{~B}$ \\
\hline Humerus & Oryctolagus & Late Neolithic & $\mathrm{F}$ & - & 83 & - & - & 38 & - & Sul & 73 & M3 \\
\hline Humerus & Oryctolagus & Evolved Early Neolithic & $\mathrm{F}$ & - & 79 & - & - & 35 & - & Sul & 107 & N4C/N3A \\
\hline Humerus & Oryctolagus & Evolved Early Neolithic & $\mathrm{F}$ & - & 79 & - & - & 37 & - & Sul & 94 & M3C \\
\hline Humerus & Oryctolagus & Evolved Early Neolithic & $\mathrm{F}$ & - & 79 & - & - & 42 & - & Sul & 103 & \begin{tabular}{|l|}
$\mathrm{K} 4 \mathrm{D} / \mathrm{L} 4 \mathrm{C} /$ \\
$\mathrm{L} 4 \mathrm{D}$ \\
\end{tabular} \\
\hline Humerus & Oryctolagus & Evolved Early Neolithic & $\mathrm{F}$ & - & 81 & - & - & 36 & - & Sul & 52 & N4D \\
\hline Humerus & Oryctolagus & Evolved Early Neolithic & $\mathrm{F}$ & - & 82 & - & - & 39 & - & Sul & 85 & L4D \\
\hline Humerus & Oryctolagus & Evolved Early Neolithic & $\mathrm{F}$ & - & 86 & - & - & 38 & - & Sul & 52 & N4D \\
\hline Humerus & Oryctolagus & Early Neolithic & - & - & 87 & - & - & 41 & - & M21 & 27 & 5 \\
\hline Humerus & Oryctolagus & Early Neolithic & $\mathrm{F}$ & - & - & - & - & 39 & - & J-K17/18 & 39 & 1 \\
\hline Humerus & Oryctolagus & Early Neolithic & $\mathrm{F}$ & - & 80 & - & - & 38 & - & Sul & 53 & P3B \\
\hline Humerus & Oryctolagus & Early Neolithic & $\mathrm{F}$ & - & 81 & - & - & 41 & - & E9 & $7 / 8$ & - \\
\hline Humerus & Oryctolagus & Early Neolithic & $\mathrm{F}$ & - & 82 & - & - & 39 & - & Sul & 53 & - \\
\hline Humerus & Oryctolagus & Early Neolithic & $\mathrm{F}$ & - & 83 & - & - & 40 & - & Sul & 53 & $\mathrm{P} 4$ \\
\hline Humerus & Oryctolagus & Early Neolithic & $\mathrm{F}$ & - & 89 & - & - & 39 & - & Sul & 53 & N3A \\
\hline Humerus & Oryctolagus & Mousterian & $?$ & - & - & - & - & 45 & - & Sul & 136 & $\mathrm{~N} 4 \mathrm{~A}$ \\
\hline Humerus & Oryctolagus & Mousterian & $\mathrm{F}$ & - & 82 & - & - & 41 & - & Sul & 6 & M4 \\
\hline Humerus & Ovis aries & Late Chalcolithic & $\mathrm{F}$ & - & - & - & 282 & 140 & - & N4 & 4 & - \\
\hline Humerus & Ovis aries & Late Neolithic & $\mathrm{F}$ & - & - & - & 287 & 134 & BT = approx. & Sul & $68 / 63$ & G3A \\
\hline Humerus & Ovis aries & Late Neolithic & $\mathrm{F}$ & - & - & - & 296 & 148 & - & Sul & 71 & L4C \\
\hline Humerus & Ovis aries & Early Neolithic & $\mathrm{F}$ & - & - & - & 276 & 136 & - & Sul & 53 & P3B \\
\hline Humerus & Ovis aries & Early Neolithic & $\mathrm{F}$ & - & - & - & 279 & 135 & - & M21 & 27 & 2 \\
\hline Humerus & Ovis aries & Early Neolithic & $\mathrm{Fv}$ & - & - & - & 279 & 137 & - & Sul & 53 & M4 \\
\hline Humerus & Ovis aries? & Late Neolithic & $\mathrm{F}$ & - & - & - & 313 & 152 & - & Sul & 74 & $\mathrm{~J} 4 \mathrm{C}$ \\
\hline Humerus & Ovis aries? & Late Neolithic & $\mathrm{F}$ & - & - & - & 317 & 164 & - & Sul & 71 & $\mathrm{~L} 4 \mathrm{C}$ \\
\hline Humerus & Ovis aries? & Late Neolithic & $\mathrm{F}$ & - & - & - & 318 & 161 & both msmnts = approx & Corte E-O & UC4 II & M4 \\
\hline Humerus & Ovis aries? & Late Neolithic & $\mathrm{Fv}$ & - & - & - & 264 & 135 & BT = approx. & Corte E-O & $4 \mathrm{III}$ & M4 \\
\hline Humerus & Ovis aries? & Evolved Early Neolithic & $\mathrm{F}$ & - & - & - & 260 & 131 & - & Sul & 52 & $\mathrm{~N} 4 \mathrm{C}$ \\
\hline Humerus & Ovis aries? & Evolved Early Neolithic & $\mathrm{F}$ & - & - & - & 283 & 138 & - & Sul & 52 & P3B \\
\hline Humerus & Ovis aries? & Early Neolithic & $\mathrm{F}$ & - & - & - & 271 & 136 & - & Sul & 53 & L3B \\
\hline Humerus & Ovis aries? & Early Neolithic & $\mathrm{F}$ & - & - & - & 288 & 144 & - & Sul & 53 & L4D \\
\hline Humerus & Ovis/Capra & Late Neolithic & - & - & - & - & 311 & 151 & - & Sul & 78 & $\mathrm{H} 3 \mathrm{C}$ \\
\hline Humerus & Ovis/Capra & Late Neolithic & $?$ & - & - & - & 294 & 148 & BT = approx. & - & $4 \mathrm{III}$ & N4 \\
\hline Humerus & Ovis/Capra & Late Neolithic & $\mathrm{F}$ & - & - & - & - & 134 & - & Sul & 68 & K3D \\
\hline Humerus & Ovis/Capra & Late Neolithic & $\mathrm{F}$ & - & - & - & 302 & 145 & - & - & $4 \mathrm{III}$ & M4 \\
\hline Humerus & Ovis/Capra & Late Neolithic & $\mathrm{F}$ & - & - & - & 304 & 149 & - & - & $4 \mathrm{III}$ & $\mathrm{P} 4$ \\
\hline Humerus & Ovis/Capra & Late Neolithic & $\mathrm{F}$ ? & - & - & - & 275 & 135 & - & Sul & 66 & $\mathrm{~K} 4 \mathrm{C}$ \\
\hline Humerus & Ovis/Capra & Evolved Early Neolithic & $?$ & - & - & - & - & 131 & - & Sul & 75 & $\mathrm{~J} 2 \mathrm{~A}$ \\
\hline
\end{tabular}




\begin{tabular}{|c|c|c|c|c|c|c|c|c|c|c|c|c|}
\hline Bone & Taxon & Period & Fus & GL & Bd & Dd & BT & HTC & \begin{tabular}{|l} 
Notes \\
\end{tabular} & Sector & UE & Ambiente \\
\hline Humerus & Ovis/Capra & Early Neolithic & - & - & - & - & 287 & 144 & BT = approx. & E10 & $7 / 8$ & - \\
\hline Humerus & Ovis/Capra & Early Neolithic & $\mathrm{F}$ & - & - & - & - & 126 & - & Sul & 53 & M4 \\
\hline Humerus & Ovis/Capra & Early Neolithic & $\mathrm{Fv}$ & - & - & - & 279 & 154 & - & Sul & 53 & M4 \\
\hline Humerus & Sus & Late Neolithic & $\mathrm{F}$ & - & - & - & - & 167 & - & - & 82 & H4D \\
\hline Humerus & Sus & Late Neolithic & $\mathrm{F}$ & - & - & - & 280 & 180 & - & Sul & 78 & G3D \\
\hline Humerus & Sus & Late Neolithic & $\mathrm{F}$ & - & - & - & 293 & 189 & - & Sul & 68 & $\mathrm{~J} 2 \mathrm{~A}$ \\
\hline Humerus & Sus & Late Neolithic & $\mathrm{F}$ & - & - & - & 316 & 185 & - & Sul & 68 & M3D \\
\hline Humerus & Sus & Evolved Early Neolithic & $\mathrm{F}$ & - & - & - & - & 190 & - & Sul & 95 & G3D \\
\hline Humerus & Sus & Early Neolithic & $\mathrm{F}$ & - & - & - & 287 & 187 & - & Sul & 53 & N3A \\
\hline Humerus & Sus & Early Neolithic & $\mathrm{Fv}$ & - & - & - & 310 & 215 & suture very visible & M21 & 27 & 2 \\
\hline Humerus & Sus & Early Neolithic & UE & - & - & - & 281 & 186 & - & Sul & 53 & - \\
\hline Humerus & Sus & Early Neolithic & UE & - & - & - & 281 & 204 & - & E9 & $7 / 8$ & - \\
\hline Humerus & Sus & Early Neolithic & UE & - & - & - & 289 & 198 & - & J17 & 39 & - \\
\hline Humerus & Sus & Early Neolithic & UE & - & - & - & 291 & 192 & - & M21 & 27 & 2 \\
\hline Humerus & Sus & Early Neolithic & UE & - & - & - & 320 & 209 & - & Sul & 53 & N3 \\
\hline Humerus & Vulpes vulpes & Early Neolithic & $\mathrm{F}$ & 1139 & 199 & - & - & 77 & GLC $=1113$ & L20 & 26 & - \\
\hline Tibia & Bos & Late Neolithic & $\mathrm{F}$ & - & 580 & 426 & - & - & - & Sul & 68 & M4D \\
\hline Tibia & Bos & Late Neolithic & $\mathrm{F}$ & - & 680 & - & - & - & $\mathrm{Bd}=$ approx & Sul & 68 & K3A \\
\hline Tibia & Bos & Late Neolithic & UE & - & 525 & - & - & - & $\begin{array}{l}\mathrm{Bd}=\text { approx } 52-53 \\
\mathrm{~mm}\end{array}$ & Sul & 68 & M4D \\
\hline Tibia & Capreolus? & Early Neolithic & $\mathrm{F}$ & - & 262 & - & - & - & - & Sul & 125 & K3D/K3B \\
\hline Tibia & \begin{tabular}{|l} 
Cervus \\
elaphus
\end{tabular} & Late Neolithic & $\mathrm{F}$ & - & 417 & 294 & - & - & - & Sul & 68 & $\mathrm{~J} 3 / \mathrm{J} 4$ \\
\hline Tibia & Oryctolagus & Late Neolithic & $\mathrm{F}$ & - & 106 & - & - & - & - & Sul & 68 & L3C \\
\hline Tibia & Oryctolagus & Late Neolithic & $\mathrm{F}$ & - & 114 & - & - & - & - & Sul & 68 & L3C \\
\hline Tibia & Oryctolagus & Late Neolithic & $\mathrm{F}$ & - & 118 & - & - & - & - & Sul & 68 & M4C \\
\hline Tibia & Oryctolagus & Early Neolithic & $\mathrm{F}$ & - & 106 & - & - & - & - & E9 & 10 & - \\
\hline Tibia & Oryctolagus & Early Neolithic & $\mathrm{F}$ & - & 110 & - & - & - & - & J-K17/18 & 39 & 3 \\
\hline Tibia & Oryctolagus & Early Neolithic & $\mathrm{F}$ & - & 111 & - & - & - & - & $\mathrm{J} 17 / \mathrm{K} 17$ & 39 & 1 \\
\hline Tibia & Oryctolagus & Mousterian & $\mathrm{F}$ & - & 121 & - & - & - & $\begin{array}{l}\text { large - perhaps small } \\
\text { hare? }\end{array}$ & Sul & 149 & $\mathrm{~N} 4 \mathrm{~A} / \mathrm{N} 5 \mathrm{C}$ \\
\hline Tibia & Sus & Late Neolithic & $\mathrm{F}$ & - & 272 & 224 & - & - & - & \begin{tabular}{|l|} 
Sul Corte \\
EO
\end{tabular} & UC 4 II & M4 \\
\hline Tibia & Sus & Late Neolithic & $\mathrm{Fv}$ & - & 269 & - & - & - & - & Sul & 73 & K3D \\
\hline Tibia & Sus & Late Neolithic & UE & - & 291 & - & - & - & - & Sul & 73 & $\mathrm{~J} 3 \mathrm{D}$ \\
\hline Tibia & Sus & Evolved Early Neolithic & $\mathrm{F}$ & - & 314 & - & - & - & - & Sul & 101 & K3D/K3B \\
\hline Tibia & Sus & Early Neolithic & UE & - & 273 & - & - & - & - & E9 & 10 & - \\
\hline Tibia & Sus & Early Neolithic & UE & - & 307 & - & - & - & - & $\mathrm{J} 17$ & 39 & 4 \\
\hline Tibia & Sus & Early Neolithic & $\mathrm{UE}$ & - & 309 & - & - & - & - & Sul & 53 & M3C \\
\hline
\end{tabular}

\section{APPENDIX TABLE}

Lameiras - measurements in tenths of a millimeter of the humeri, tibiae and a femur. Key: Fus = state of epiphysial fusion (F fused, UE unfused, Fv fused but with suture still visible). The taxa are: Bos - Bos taurus/primigenius cattle/aurochs, Capreolus capreolus roe deer, Capra hircus goat, Cervus elaphus red deer, Oryctolagus cuniculus rabbit, Lepus hare, Ovis aries sheep, Sus pig/wild boar. Measurements follow Driesch (1976) and Davis (1996). Approximate measurements are noted in the "notes" column. 
APPENDIX A. LAMEIRAS BONE MEASUREMENTS METAPODIALS

\begin{tabular}{|c|c|c|c|c|c|c|c|c|c|c|c|c|c|c|c|}
\hline Bone & Taxon & Period & Fus & GL & Bd & Dd & WCM & DEM & WCL & DEL & SD & Notes & Sector & UE & Ambiente \\
\hline Metacarpal & Bos & Late Neolithic & $\mathrm{F}$ & - & 640 & 336 & 297 & 242 & 307 & 260 & - & Dd = approx & Sul & 68 & $\mathrm{~K} 3 \mathrm{~A}$ \\
\hline Metacarpal & Bos & Late Neolithic & $\mathrm{F}$ & - & 724 & 401 & 353 & 316 & 332 & 291 & - & Dd = approx & Sul & 78 & $\mathrm{H} 3 \mathrm{~A}$ \\
\hline Metacarpal & Bos & $\begin{array}{l}\text { Evolved Early } \\
\text { Neolithic }\end{array}$ & UE & - & 633 & 372 & 288 & 276 & 285 & 256 & - & - & Sul & 52 & $\mathrm{~N} 4 \mathrm{C}$ \\
\hline Metacarpal & $\begin{array}{l}\text { Capra } \\
\text { hircus }\end{array}$ & Early Neolithic & UE & - & 317 & 189 & 151 & 106 & 150 & 113 & - & definite goat & E9 & $10-2$ & - \\
\hline $\begin{array}{l}\text { Metacarpal } \\
\text { half }\end{array}$ & $\begin{array}{l}\text { Capra } \\
\text { hircus }\end{array}$ & Late Neolithic & $\mathrm{F}$ & - & - & - & 120 & 84 & - & - & - & $\begin{array}{l}\text { medial or lateral } \\
\text { condyle measured }\end{array}$ & Sul & 73 & L3A \\
\hline $\begin{array}{l}\text { Metacarpal } \\
\text { half }\end{array}$ & $\begin{array}{l}\text { Capra } \\
\text { hircus }\end{array}$ & $\begin{array}{l}\text { Evolved Early } \\
\text { Neolithic }\end{array}$ & UE & - & - & - & 150 & 114 & - & - & - & $\begin{array}{l}\text { medial or lateral } \\
\text { condyle measured }\end{array}$ & Sul & 103 & $\begin{array}{l}\mathrm{K} 4 \mathrm{D} / \mathrm{L} 4 \mathrm{C} / \\
\mathrm{L} 4 \mathrm{D}\end{array}$ \\
\hline $\begin{array}{l}\text { Metacarpal } \\
\text { half? }\end{array}$ & $\begin{array}{l}\text { Capra } \\
\text { hircus }\end{array}$ & Late Neolithic & UE & - & - & - & 113 & 85 & - & - & - & $\begin{array}{l}\text { medial or lateral } \\
\text { condyle measured }\end{array}$ & Sul & 71 & L3B \\
\hline $\begin{array}{l}\text { Metacarpal } \\
\text { half? }\end{array}$ & $\begin{array}{l}\text { Capra } \\
\text { hircus }\end{array}$ & Early Neolithic & UE & - & - & - & 110 & 97 & - & - & - & $\begin{array}{l}\text { medial or lateral } \\
\text { condyle measured }\end{array}$ & Sul & 53 & N4 \\
\hline $\begin{array}{l}\text { Metacarpal } \\
\text { half? }\end{array}$ & $\begin{array}{l}\text { Capra } \\
\text { hircus? }\end{array}$ & Early Neolithic & Fv & - & - & - & 123 & 115 & - & - & - & $\begin{array}{l}\text { medial or lateral } \\
\text { condyle measured }\end{array}$ & Sul & 110 & $\mathrm{M} 3 \mathrm{~A} / \mathrm{M} 3 \mathrm{C}$ \\
\hline Metacarpal & Ovis aries & Early Neolithic & $\mathrm{F}$ & - & - & - & 109 & 97 & - & - & - & - & Sul & 53 & M3A \\
\hline Metacarpal & Ovis aries & Early Neolithic & $\mathrm{F}$ & - & 244 & 153 & 117 & 108 & 112 & 105 & - & $\begin{array}{l}\text { Dd = approx } \\
\text { definite sheep }\end{array}$ & Sul & 53 & N4D \\
\hline Metacarpal & Ovis aries & Early Neolithic & UE & - & 215 & 140 & 104 & 101 & 105 & 94 & - & - & E9 & $10-6$ & - \\
\hline Metacarpal & Ovis aries? & $\begin{array}{l}\text { Evolved Early } \\
\text { Neolithic } \\
\end{array}$ & $\mathrm{F}$ & - & 235 & 160 & 112 & 99 & 102 & 96 & - & - & Sul & 107 & $\mathrm{~N} 4 \mathrm{C} / \mathrm{N} 3 \mathrm{~A}$ \\
\hline $\begin{array}{l}\text { Metacarpal } \\
\text { half }\end{array}$ & Ovis aries & $\begin{array}{l}\text { Evolved Early } \\
\text { Neolithic }\end{array}$ & $\mathrm{Fv}$ & - & - & - & 123 & 110 & - & - & - & $\begin{array}{l}\text { medial or lateral } \\
\text { condyle measured }\end{array}$ & Sul & 52 & M4D \\
\hline $\begin{array}{l}\text { Metacarpal } \\
\text { half }\end{array}$ & Ovis/Capra & Early Neolithic & UE & - & - & - & 107 & 100 & - & - & - & $\begin{array}{l}\text { medial or lateral } \\
\text { condyle measured }\end{array}$ & E9 & $10-6$ & - \\
\hline Metatarsal & $\begin{array}{l}\text { Equus } \\
\text { ?caballus }\end{array}$ & Late Chalcolithic & $\mathrm{F}$ & 2489 & 461 & 346 & - & - & - & - & 292 & $\begin{array}{l}\mathrm{Bp}=450 \mathrm{Ll}= \\
2459\end{array}$ & Sul & 4 & N4 \\
\hline Metapodial & Equus & Late Chalcolithic & $\mathrm{F}$ & - & 302 & - & - & - & - & - & - & $\begin{array}{l}\text { v. small - E.?hy- } \\
\text { druntinus Bd = } \\
\text { approx. }\end{array}$ & Sul & 3 & $\mathrm{~J} 3$ \\
\hline Metatarsal & Bos & Late Neolithic & $\mathrm{F}$ & - & 517 & 313 & 250 & 229 & 235 & 211 & - & - & Sul & 68 & M4C \\
\hline Metatarsal & Bos & Late Neolithic & $\mathrm{F}$ & - & 589 & 320 & 277 & 238 & 267 & 226 & - & $\begin{array}{l}\text { condyles medial or } \\
\text { lateral unclear }\end{array}$ & Sul & 73 & $\mathrm{~K} 3 \mathrm{C}$ \\
\hline $\begin{array}{l}\text { Metatarsal } \\
\text { half }\end{array}$ & Bos & Early Neolithic & $\mathrm{F}$ & - & - & - & 319 & 257 & - & - & - & $\begin{array}{l}\text { estimated } \mathrm{BFd}= \\
73 \mathrm{~mm}\end{array}$ & Sul & 53 & $\mathrm{M} 4 \mathrm{C}$ \\
\hline Metatarsal & Bos & Early Neolithic & $\mathrm{F}$ & - & 540 & 333 & 261 & 250 & 254 & 232 & - & - & E9 & $10-2$ & - \\
\hline Metatarsal & Ovis aries & Early Neolithic & $\mathrm{F}$ & - & 234 & 150 & - & - & - & - & - & $\mathrm{Dd}=$ approx & Sul & $\begin{array}{c}118- \\
2 \\
\end{array}$ & L4D/L3B \\
\hline Metatarsal & Ovis aries & Early Neolithic & $\mathrm{F}$ & - & 248 & 164 & - & - & - & - & - & Dd = approx & Sul & 125 & $\mathrm{~K} 3 \mathrm{D} / \mathrm{K} 3 \mathrm{~B}$ \\
\hline Metatarsal & Ovis aries? & Early Neolithic & UE & - & 287 & 179 & - & - & - & - & - & $\mathrm{Bd}=$ approx & M11/12 & 11 & - \\
\hline Metatarsal & Ovis aries & $\begin{array}{l}\text { Evolved Early } \\
\text { Neolithic }\end{array}$ & - & - & 237 & 156 & 111 & 106 & 109 & 100 & - & $\begin{array}{l}\text { definite sheep pro- } \\
\text { bably metatarsal }\end{array}$ & Sul & 52 & P3A \\
\hline
\end{tabular}

APPENDIX TABLE

Lameiras - measurements in tenths of a millimeter of the metapodials. Key: Fus = state of epiphysial fusion (F fused, UE unfused, Fv fused but with suture still visible). The taxa are: Bos - Bos taurus/primigenius cattle/aurochs, Equus ? caballus equid - probably horse, Capra hircus goat, Ovis aries sheep. Measurements follow Driesch (1976) and Davis (1996). Approximate measurements are noted in the "notes" column. 


\section{APPENDIX A. LAMEIRAS BONE MEASUREMENTS SCAPULA + RADIUS + CALCANEUM}

\begin{tabular}{|c|c|c|c|c|c|c|c|c|c|c|c|c|}
\hline Bone & Taxon & Period & Fus & GL & Bd & Dd & SD & SLC & Notes & Sector & $\mathbf{U E}$ & Ambiente \\
\hline Calcaneum & Felis silvestris & Early Neolithic & $\mathrm{F}$ & 288 & - & - & - & - & - & $\mathrm{J}-\mathrm{K} / 17-18$ & 39 & 2 \\
\hline Calcaneum & Felis silvestris & Early Neolithic & $\mathrm{F}$ & 290 & - & - & - & - & - & JK17-18 & 39 & 8 \\
\hline Calcaneum & Lepus & Late Neolithic & $\mathrm{F}$ & 287 & - & - & - & - & - & Sul & 71 & L4D \\
\hline Calcaneum & Oryctolagus & Late Chalcolithic & $\mathrm{F}$ & 212 & - & - & - & - & - & Sul & 3 & - \\
\hline Calcaneum & Oryctolagus & Late Chalcolithic & $\mathrm{F}$ & 212 & - & - & - & - & - & Sul & 3 III & - \\
\hline Calcaneum & Oryctolagus & Late Neolithic & $\mathrm{F}$ & 192 & - & - & - & - & - & Sul & 68 & M4D \\
\hline Calcaneum & Oryctolagus & Late Neolithic & $\mathrm{F}$ & 209 & - & - & - & - & - & Sul & 86 & $\mathrm{H} 4 \mathrm{D}$ \\
\hline Calcaneum & Oryctolagus & Early Neolithic & $\mathrm{F}$ & 197 & - & - & - & - & - & M20 & 26 & 3 \\
\hline Calcaneum & Oryctolagus & Early Neolithic & $\mathrm{F}$ & 205 & - & - & - & - & - & JK17-18 & 39 & 2 \\
\hline Calcaneum & Oryctolagus & Early Neolithic & $\mathrm{F}$ & 209 & - & - & - & - & - & E9 & $10-2$ & - \\
\hline Calcaneum & Oryctolagus & Early Neolithic & $\mathrm{F}$ & 217 & - & - & - & - & - & E9 & $7 / 8$ & - \\
\hline Calcaneum & Oryctolagus & Early Neolithic & $\mathrm{F}$ & 218 & - & - & - & - & - & M20 & 26 & 3 \\
\hline Calcaneum & Ovis aries? & Early Neolithic & $\mathrm{F}$ & 637 & - & - & - & - & - & L20/M20 & 26 & 5 \\
\hline $\begin{array}{l}\text { Proximal } \\
\text { phalanx }\end{array}$ & Bos & Early Neolithic & $\mathrm{F}$ & 704 & 299 & 227 & 258 & - & $\mathrm{Bp}=314$ & J-K17 & 39 & 3 \\
\hline Scapula & Bos & Early Neolithic & $\mathrm{F}$ & - & - & - & - & 633 & - & L20 & 26 & 3 \\
\hline Scapula & Oryctolagus & Evolved Early Neolithic & $\mathrm{F}$ & - & - & - & - & 46 & - & Sul & 103 & L3B \\
\hline Scapula & Oryctolagus & Early Neolithic & $\mathrm{F}$ & - & - & - & - & 42 & - & Sul & 53 & $\mathrm{~N} 4$ \\
\hline Scapula & Sus & Late Neolithic & - & - & - & - & - & 218 & - & Sul & 68 & $\mathrm{~J} 2 \mathrm{~A}$ \\
\hline Scapula & Sus & Late Neolithic & $?$ & - & - & - & - & 229 & - & Sul & 68 & M3C \\
\hline Scapula & Sus & Late Neolithic & $?$ & - & - & - & - & 231 & - & Sul & 71 & $\mathrm{~K} 4 \mathrm{D}$ \\
\hline Scapula & Sus & Late Neolithic & $\mathrm{F}$ & - & - & - & - & 220 & - & Sul & 73 & $\mathrm{~K} 3 \mathrm{D}$ \\
\hline Scapula & Sus & Late Neolithic & $\mathrm{F}$ & - & - & - & - & 224 & - & Sul & 74 & $\mathrm{H} 4 \mathrm{D}$ \\
\hline Scapula & Sus & Late Neolithic & $\mathrm{F}$ & - & - & - & - & 225 & - & Sul & 68 & M3B \\
\hline Scapula & Sus & Evolved Early Neolithic & $\mathrm{F}$ & - & - & - & - & 253 & - & Sul & 107 & N4D \\
\hline Scapula & Sus & Evolved Early Neolithic & $\mathrm{U}$ & - & - & - & - & 132 & - & Sul & 103 & L3B \\
\hline Scapula & Sus & Evolved Early Neolithic & $\mathrm{U}$ & - & - & - & - & 252 & - & Sul & 52 & M4 \\
\hline Scapula & Sus & Early Neolithic & $\mathrm{F}$ & - & - & - & - & 264 & - & Sul & 118 & L4D/L3D \\
\hline Scapula & Sus & Early Neolithic & $\mathrm{U}$ & - & - & - & - & 216 & - & M15/16 & 44 & - \\
\hline Ulna & Accipiter & Early Neolithic & - & 1125 & - & - & - & - & $\begin{array}{l}\text { Accipiter } \text { cf gentilis } \\
\mathrm{Bp}=134\end{array}$ & $\mathrm{~J} 17$ & 39 & 4 \\
\hline Radius & Accipiter & Early Neolithic & - & 1039 & 83 & - & - & - & - & $\mathrm{J} 17$ & 39 & 4 \\
\hline $\begin{array}{l}\text { Tarsome- } \\
\text { tarsus }\end{array}$ & Buteo? & Early Neolithic & - & - & 137 & - & - & - & cf Buteo buteo & JK17-18 & 39 & 4 \\
\hline
\end{tabular}

\section{APPENDIX TABLE}

Lameiras - measurements in tenths of a millimeter of the scapulae, radii, calcanea, ulna, tarsometatarsus and a proximal phalanx. Key: Fus $=$ state of epiphysial fusion (F fused, $\mathrm{U}$ unfused coracoid). The taxa are: Bos - Bos taurus/primigenius cattle/aurochs, Oryctolagus cuniculus rabbit, Ovis aries sheep, Sus pig/wild boar, Accipiter hawk, Buteo buzzard. Measurements follow Driesch (1976). 
APENDIX A. LAMEIRAS TEETH - MSMNTS

\begin{tabular}{|c|c|c|c|c|c|c|c|c|c|c|c|c|c|c|c|c|c|c|c|c|c|c|c|c|c|c|c|c|c|}
\hline 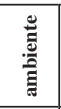 & & 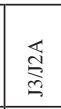 & 寿 & 讨 & 离 & 웧 & $\stackrel{\Re}{3}$ & $\ddot{\mathscr{g}}$ & 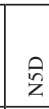 & & & & & & 离 & $\stackrel{\infty}{3}$ & 鿖 & 艺 & సิ & 趈 & $\begin{array}{l}q \\
\end{array}$ & 今ે & 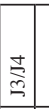 & $\begin{array}{c}0 \\
\text { S }\end{array}$ & 志 & $\mathbb{I}$ & 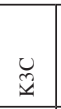 & 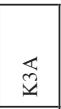 & 荎 \\
\hline 5 & + & $\begin{array}{l} \\
\text { 유 } \\
\end{array}$ & $\stackrel{\infty}{\stackrel{2}{2}}$ & 亲 & $\infty$ & \begin{tabular}{|l|} 
\\
\end{tabular} & $\stackrel{\Omega}{\varrho}$ & 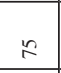 & $\stackrel{\oplus}{-}$ & ב & 永 & 疝 & & E & $\approx$ & $\approx$ & \pm & $\begin{array}{l}\exists \\
\end{array}$ & 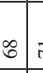 & & $=:$ & $\stackrel{\infty}{\curvearrowright}$ & 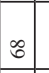 & 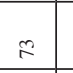 & $\stackrel{\infty}{\sim}$ & $\approx$ & 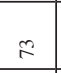 & 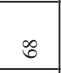 & in \\
\hline 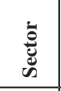 & $\frac{ \pm}{2}$ & $\bar{B}$ & $\bar{E}$ & $\bar{E}$ & $\bar{B}$ & $\bar{\Xi}$ & $\bar{B}$ & $\bar{E}$ & $\bar{B}$ & $\overline{0}$ & $\bar{B}$ & $\bar{\Delta}$ & & $\bar{E}$ & $\bar{\Xi}$ & $\overline{\bar{n}}$ & $\Xi$ & & $\bar{B}$ & $\bar{E} \bar{v}$ & $\bar{\Xi} \bar{\Xi}$ & $\bar{\Xi}$ & \begin{tabular}{|l|l|} 
& \\
\end{tabular} & $\bar{\Xi}$ & $\bar{B}$ & \begin{tabular}{|l|} 
\\
\end{tabular} & $\bar{B}$ & $\bar{B}$ & $\bar{E}$ \\
\hline 总 & & & 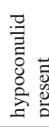 & 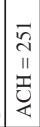 & & 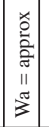 & 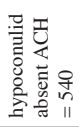 & 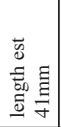 & 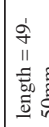 & $\begin{array}{l}2 \\
2\end{array}$ & $\begin{array}{ll}5 \\
2\end{array}$ & & 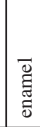 & 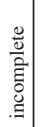 & . & & & & $\begin{array}{l}\sum_{n}^{n} \\
0 \\
0 \\
0 \\
\vdots\end{array}$ & & & & & 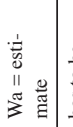 & 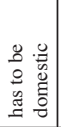 & & 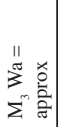 & 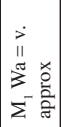 & 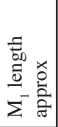 \\
\hline \begin{tabular}{|l|} 
\\
$\sum^{2}$ \\
$\sum^{-1}$ \\
$\sum^{-}$
\end{tabular} & & & & & & & & & ' & 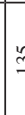 & & & & & ' & ' & & & 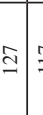 & $\exists \stackrel{9}{9}$ & 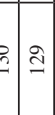 & & & ' & ' & & ' & ' & \\
\hline $\begin{array}{l}\Sigma^{\pi} \\
\sum^{-1} \\
\Sigma^{-}\end{array}$ & & & & & & & & & ' & : & 㩆 & & & & ' & . & & & త్ & 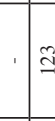 & $\stackrel{\Omega}{9}$ & & ' & ' & ' & & ' & ' & \\
\hline 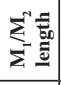 & & & I & & & & & & ' & 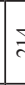 & $\bar{\lambda}$ & & & & ' & . & & & & 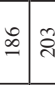 & $\stackrel{\mathrm{N}}{\mathrm{N}}$ & & , & ' & . & & ' & ' & \\
\hline$\sum_{\bar{z}}^{0}$ & & $\Xi$ & I & $\cong$ & 杰 & & g & $\stackrel{8}{6}$ & ' & . & & & $\exists$ & 标 & , & . & ' & 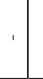 & ' & . & . & , & 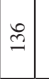 & छ & ले & 导 & q & fo & ' \\
\hline$\sum^{\infty}$ & $\stackrel{\infty}{\stackrel{2}{n}}$ & $\stackrel{\sim}{\infty}$ & ' & 酌 & $\underline{6}$ & $\begin{array}{l}\infty \\
\stackrel{\infty}{\sim}\end{array}$ & in & $\stackrel{\infty}{\infty}$ & $\widetilde{\Omega}$ & & & & is & है & ' & . & & & ' & & & & 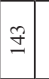 & $\stackrel{n}{n}$ & $\stackrel{0}{+}$ & $\stackrel{\infty}{\stackrel{\infty}{\circ}}$ & g & $\stackrel{n}{n}$ & \\
\hline 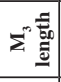 & $\tilde{\mathrm{n}}$ & $\overline{\text { లె }}$ & ' & 항 & $\stackrel{\hat{m}}{0}$ & ' & ' & ' & : & & & ' & ले & te & . & . & & & ' & . & & & $\stackrel{\rho}{ल}$ & हे & $\stackrel{\infty}{\circ}$ & ब्रे| & लె & $\frac{0}{m}$ & \\
\hline$\sum_{i}^{\infty}$ & & & ' & & & & & , & ' & & & $\exists$ & & & I & , & & & & & & & $\left|\begin{array}{c}\infty \\
\hdashline \\
\hdashline\end{array}\right|$ & ' & ' & & ' & $\bar{m}$ & \\
\hline$\sum_{\Sigma}^{\pi}$ & & & ' & , & & & & ' & . & & & $\tilde{m}$ & & & , & . & & & & & & $\stackrel{q}{ \pm}$ & 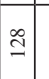 & ' & ' & & ' & $\underline{I}$ & \\
\hline 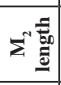 & & ' & . & . & &. & . & ' & ' & & & ' & & & , & , & , & & . & ' & , & . & đ̊ & , & ' & ' & , & $\stackrel{\sim}{\circ}$ & . \\
\hline \begin{tabular}{l|} 
\\
$\sum_{j}$
\end{tabular} & & , & , & , & & & 1 & , & ' & & & $\stackrel{9}{2}$ & & & 2 & . & & & & & & $\stackrel{\infty}{\stackrel{\infty}{2}}$ & & . & . & & . & 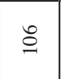 & \\
\hline \begin{tabular}{|l|}
$\pi$ \\
$\sum^{2}$
\end{tabular} & & . & , & ' & & & . & . & ' & & & , & & & 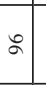 & ' & , & , & ' & $\begin{array}{ll}1 . \\
\end{array}$ & & $\bar{m}$ & 王 & ' & . & & ' & $\bar{\sigma}$ & $\S$ \\
\hline 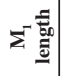 & & & . & 1 & & & . & . & . & & & & & & in & & & & , & , & & ¿े & & . & . & & . & $\stackrel{\infty}{n}$ & $\stackrel{ \pm}{\Xi}$ \\
\hline$\vec{E}$ & & ' & , & . & & & . & . & ' & & & & & & $F$ & $\infty$ & $\approx$ & 8 & & 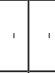 & ' &. & . & . & . & ' & , & , & 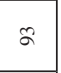 \\
\hline 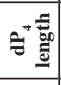 & & & . & & & & & , & . & & & & & & 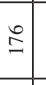 & & & ¿্స & & & & & , & . & . & & , & , & 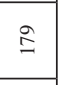 \\
\hline \begin{tabular}{|l|} 
\\
产 \\
产 \\
言 \\
\end{tabular} & $\Sigma$ & $\Sigma^{n}$ & $\Sigma$ & $\Sigma^{n}$ & $\sum$ & हे & $\Sigma$ & $\Sigma^{n}$ & $\Sigma$ & $\bar{z}$ & - & $\begin{array}{l}\Sigma \\
\Sigma\end{array}$ & $\Sigma$ & $\Sigma^{n}$ & $\begin{array}{l}\sum_{1}^{-1} \\
\overbrace{}^{\infty}\end{array}$ & $\Theta^{+}$ & $z^{+}$ & $\mathrm{z}^{+}$ & $\begin{array}{l}\sum^{n} \\
\Sigma^{-}\end{array}$ & $\begin{array}{l}\sum^{N} \\
\Sigma\end{array}$ & $\begin{array}{l}n=1 \\
\Sigma \\
\Sigma\end{array}$ & $\mid \begin{array}{l}\Sigma^{-} \\
\Sigma^{-}\end{array}$ & \begin{tabular}{|l|}
$\sum^{-1}$ \\
$\vdots$ \\
$\bar{\Sigma}$ \\
\end{tabular} & $\sum^{n}$ & $\Sigma^{n}$ & $\Sigma$ & $\Sigma$ & $\begin{array}{l}\sum_{i=1}^{n} \\
n^{-1}\end{array}$ & $\begin{array}{l}\sum_{i+1}^{-} \\
\hat{\theta}^{-1}\end{array}$ \\
\hline 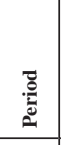 & 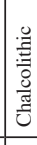 & 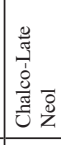 & 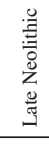 & 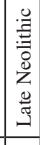 & 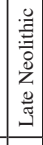 & 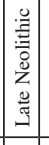 & 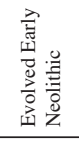 & 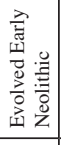 & 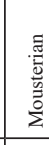 & 列 & 言 & 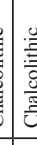 & 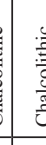 & 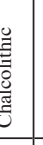 & 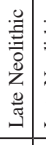 & 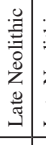 & 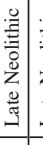 & 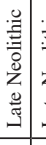 & 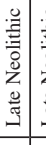 & \begin{tabular}{l|l}
0 \\
\end{tabular} & 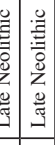 & 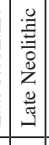 & 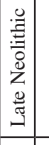 & 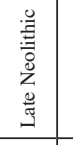 & 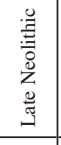 & 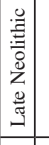 & 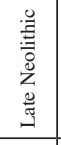 & 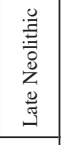 & 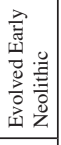 \\
\hline है & $\stackrel{ః}{\circ}$ & $\stackrel{\circ}{\circ}$ & $\stackrel{\circ}{\circ}$ & 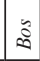 & 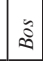 & $\mid$\begin{tabular}{l}
$\mid$ \\
0 \\
\hdashline
\end{tabular} & $\stackrel{\circ}{\circ}$ & $\stackrel{\circ}{\circ}$ & $\stackrel{0}{0}$ & 0 & 5 & $\pi$ & 0 & 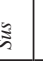 & ज & 5 & है & जี & 急 & 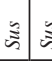 & $\begin{array}{c}n \\
\vdots\end{array}$ & 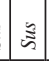 & \begin{tabular}{|c|}
\multirow{2}{*}{} \\
\end{tabular} & 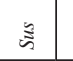 & $\stackrel{\Xi}{n}$ & \begin{tabular}{|c|c|}
5 \\
$\vdots$
\end{tabular} & 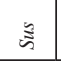 & $\tilde{3}$ & $\tilde{n}^{2}$ \\
\hline
\end{tabular}




\begin{tabular}{|c|c|c|c|c|c|c|c|c|c|c|c|c|c|c|c|c|}
\hline & Z & $\stackrel{\mathrm{m}}{\mathrm{m}}$ & 竎导导 & હ & $\stackrel{m}{3}$ & $\mathrm{~N}$ & $m$ & 1 & ' & 1 & 1 & in & 1 & 1 & - & $\sum_{\Sigma}^{m}$ \\
\hline & in & 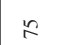 & $\stackrel{\varrho}{\varrho}$ & in & $\stackrel{\wp}{\varrho}$ & $\hat{m}$ & $\stackrel{\sim}{\sim}$ & $\bar{\lambda}$ & ले & $\vec{N}$ & $=$ & $\stackrel{\sim}{\sim}$ & $\stackrel{m}{-}$ & 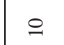 & ले & $\infty$ \\
\hline & $\bar{\Xi}$ & $\bar{B}$ & $\bar{B}$ & $\bar{B}$ & $\bar{\Xi}$ & $\begin{array}{l}\overline{\widehat{\Upsilon}} \\
\text { ড̇ }\end{array}$ & 芩 & $\overline{\mathrm{\Sigma}}$ & $\Xi$ & $\sum_{\Sigma}^{\infty}$ & $\underset{\Sigma}{\Xi}$ & $\begin{array}{l}\sum_{1}^{3} \\
\text { त̇ } \\
\end{array}$ & $\stackrel{N}{\Sigma}$ & ક્પ & $\underset{\Xi}{\stackrel{\Xi}{\Xi}}$ & $\overline{\bar{n}}$ \\
\hline & , & ' & $\begin{array}{l}\Sigma^{-} \\
0 \\
0 \\
0 \\
0\end{array}$ & ' & ' & ' & $\begin{array}{l}\tilde{y} \\
\tilde{y}\end{array}$ & , & 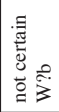 & $\begin{array}{l}\Sigma \\
\Sigma \\
0 \\
0 \\
\vdots\end{array}$ & . & & ' & ' & & 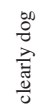 \\
\hline & ' & $\stackrel{\mathscr{m}}{\sim}$ & $\cong$ & ' & ' & , & , & ' & $\stackrel{g}{9}$ & $\Xi$ & ' & $\stackrel{\infty}{=}$ & $\vec{m}$ & $\stackrel{m}{m}$ & ' & ' \\
\hline & ' & ले & ஃ & ' & ' & ' & ' & ' & ' & $\underset{6}{8}$ & ' & 。 & $\widehat{\Xi}$ & ปे & ' & , \\
\hline & ' & ' & $\Xi$ & ' & ' & ' & ' & ' & ' & 声 & $\stackrel{\Xi}{=}$ & $\stackrel{\infty}{\sim}$ & $\stackrel{\circ}{\sim}$ & $\overline{\bar{v}}$ & ' & ' \\
\hline & . & . & . & $\stackrel{\varrho}{=}$ & 至 & . & . & . & , & ' & . & ' & ' & ' & ' & , \\
\hline & . & . & . & 寻 & $\underline{\widetilde{\sigma}}$ & . & , & . & ' & ' & . & ' & . & ' & . & . \\
\hline & ' & ' & ' & ' & 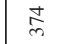 & ' & ' & ' & ' & ' & , & ' & ' & ' & ' & ' \\
\hline & ' & ' & ' & ' & ' & ' & ' & ' & ' & ' & ' & ' & ' & ' & I & ' \\
\hline & ' & . & ' & ' & ' & ' & ' & ' & , & ' & . & ' & ' & ' & 王 & ' \\
\hline & ' & , & ' & . & ' & . & ' & ' & ' & & , & & ' & , & $\widetilde{\tilde{\lambda}}$ & , \\
\hline & , & , & , & ' & ' & . & ' & ' & ' & 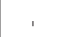 & , & 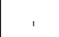 & ' & ' & , & ' \\
\hline & $\stackrel{\varrho}{\varrho}$ & , & ' & ' & ' & ' & ' & ' & ' & ' & ' & ' & ' & ' & ' & $\stackrel{2}{2}$ \\
\hline$\widehat{\widehat{\vartheta}}$ & . & . & ' & ' & . & . & . & . & ' & , & . & & ' & , & ' & $\hat{\text { iิ }}$ \\
\hline 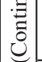 & $\sigma_{\infty}$ & . & ' & ' & . & $\Phi$ & बे & $\infty$ & . & ' & . & . & ' & , & . & , \\
\hline $\mid \begin{array}{c}n \\
\vdots \\
\Sigma \\
\Sigma\end{array}$ & $\stackrel{\odot}{\stackrel{\circ}{2}}$ & , & ' & ' & ' & ' & $\stackrel{\varrho}{ }$ & $\stackrel{\circ}{\varrho}$ & . & & ' & & , & , & ' & ' \\
\hline 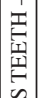 & $\begin{array}{l}\sum_{1}^{-} \\
\theta^{-}\end{array}$ & $\frac{\Sigma^{N}}{\Sigma^{-}}$ & $\sum^{N}$ & $\sum^{m}$ & $\Sigma^{n}$ & $z^{+}$ & $\theta^{+}$ & $\theta^{+}$ & $\frac{\sum^{N}}{\sum^{-}}$ & $\frac{\sum^{N}}{\Sigma^{-}}$ & $\frac{\sum^{N}}{\Sigma^{-}}$ & $\frac{\sum^{N}}{\Sigma^{-}}$ & $\frac{\sum^{N}}{\Sigma}$ & $\frac{\sum^{N}}{\Sigma^{-}}$ & $\Sigma^{N}$ & $\Sigma^{-}$ \\
\hline 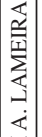 & 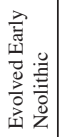 & 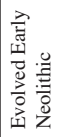 & 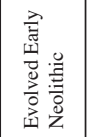 & 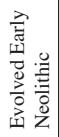 & 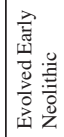 & 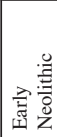 & 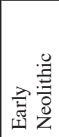 & 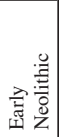 & 总吾 & 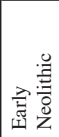 & 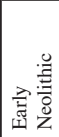 & 总竞 & 咅 & 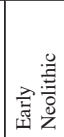 & 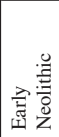 & 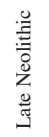 \\
\hline | & 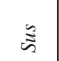 & ڤ & $\tilde{3}$ & 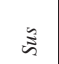 & 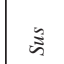 & 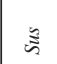 & $\tilde{s}$ & 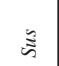 & 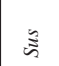 & 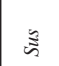 & $\tilde{\Xi}$ & 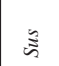 & 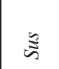 & $\tilde{\omega}$ & $\tilde{\Xi}$ & 态 \\
\hline
\end{tabular}

$\stackrel{\mathscr{F}}{\Xi}$

융

丰焉

言密

荥

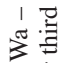

离落

焉

至

总苛

寻 ญ

署导

$1 \frac{7}{60}$

모

可高它

를

되 흘

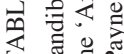

政

完皆要

â

के हे च.

몰

잉

ㄴ.

옹

政

傿

过菏

पै

要

完害

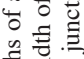

할

品声

表 放

至 1 ह

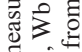

कीष

记

䇋章 
APENDIX A. LAMEIRAS TEETH - MSMNTS

\begin{tabular}{|l|c|c|c|c|c|c|c|c|c|c|}
\hline Tax & UE & Tooth & $\mathbf{L}_{\mathbf{1}}$ & $\mathbf{L}_{\mathbf{2}}$ & $\mathbf{L}_{\mathbf{3}}$ & $\mathbf{W}_{\mathbf{a}}$ & $\mathbf{W}_{\mathbf{b}}$ & $\mathbf{W}_{\mathbf{c}}$ & $\mathbf{W}_{\mathbf{d}}$ & $\mathbf{n o t e s}$ \\
\hline E. caballus & 149 & ${ }^{2} \mathrm{P}_{4}$ & 277 & 163 & 129 & 166 & 161 & 132 & 63 & - \\
\hline E. caballus & 143 & $* \mathrm{M}_{1}$ & 263 & 138 & 90 & 147 & 131 & 121 & 28 & - \\
\hline E.caballus & 149 & $\mathrm{M}_{1 / 2}$ & 250 & c. 154 & 110 & - & - & - & 37 & juv \\
\hline E. caballus & 136 & $\mathrm{M}_{1 / 2}$ & - & 143 & c. 108 & 141 & 129 & c. 118 & 24 & - \\
\hline E. caballus & 143 & $\mathrm{M}_{3}$ & 339 & 144 & 104 & 135 & 126 & 115 & 30 & - \\
\hline E. caballus & 5 & $\mathrm{M}_{3}$ & c. 325 & c. 145 & 114 & c. 150 & 144 & 128 & 22 & - \\
\hline E. caballus & $5-143$ & $\mathrm{M}_{3}$ & c. 305 & 137 & 114 & 128 & 118 & 100 & 46 & - \\
\hline
\end{tabular}

APPENDIX TABLE

Lameiras - measurements in tenths of a millimetre of the Mousterian equid teeth taken as described in Davis (2002, figure 2). *The $\mathrm{P}_{4}$ from UE 149 and the $M_{1}$ from UE 143 join and therefore belonged in the same mandible.

\section{APPENDIX B. LAMEIRAS CHALCOLITHIC TOOTH WEAR RAW DATA}

\begin{tabular}{|c|c|c|c|c|c|c|c|c|c|c|c|}
\hline Period & Sector & UE & ambiente & Tax & $\mathrm{dP}_{4}$ & $\mathbf{P}_{4}$ & $M_{1}$ & $\mathbf{M}_{2}$ & $\mathbf{M}_{3}$ & $M_{1 / 2}$ & PS \\
\hline $\mathrm{CF}$ & Sul & 3-IV & & Bos & & & & & & $1 ?$ & \\
\hline $\mathrm{CF}$ & Sul & 3 III & & Bos & & & & & & $P$ & \\
\hline $\mathrm{CF}$ & Sul & 3-IV & & Bos & & & & & $\mathrm{a} / \mathrm{b}$ & & \\
\hline $\mathrm{CF}$ & M4 & 4 & & Bos & & & & & $\mathrm{k}$ & & \\
\hline $\mathrm{CF} / \mathrm{LN}$ & Sul & $62 / 66$ & $\mathrm{~J} 3 / \mathrm{J} 2 \mathrm{~A}$ & Bos & & & & & $\mathrm{k}$ & & \\
\hline $\mathrm{CF}$ & Sul & 62 & $\mathrm{H} 3$ & Ovis/Capra & & & & & & 14 & \\
\hline $\mathrm{CF}$ & Sul & 4 & $\mathrm{~N} 3 \mathrm{~A}$ & Ovis/Capra & & & & & & 2 & \\
\hline $\mathrm{CF}$ & M4 & 4 & & Ovis/Capra & & & & & & 4 & \\
\hline $\mathrm{CF}$ & Sul & 3 III & & Ovis/Capra & & & & & & $8 / 9$ & \\
\hline $\mathrm{CF}$ & Sul & 4 & $\mathrm{~N} 3 \mathrm{~A}$ & Ovis/Capra & & & & & & 9 & \\
\hline $\mathrm{CF}$ & $\mathrm{P} 4$ & 4 & & Ovis/Capra & & & & & & 9 & \\
\hline $\mathrm{CF}$ & N4 & 4 & & Ovis/Capra & & & & & & 9 & \\
\hline $\mathrm{CF}$ & Sul & 62 & H3 & Ovis/Capra & & & & & & $9 ?$ & \\
\hline $\mathrm{CF}$ & Sul & 62 & $\mathrm{H} 3$ & Ovis/Capra & & & & & & $9 ?$ & \\
\hline $\mathrm{CF}$ & Sul & 4 & L3B & Ovis/Capra & & 0 & & & & & \\
\hline $\mathrm{CF}$ & M4 & 4 & & Ovis/Capra & & 2 & 9 & 7 & 1 & & $\mathrm{E}$ \\
\hline $\mathrm{CF}$ & Sul & 4 & L3B & Ovis/Capra & $\mathrm{P}$ & & & & & & \\
\hline $\mathrm{CF}$ & Sul & 3 & & Ovis? & 18 or 19 & & & & & & \\
\hline $\mathrm{CF}$ & Sul & 3 III & & Sus & & & & & & $\mathrm{a}$ & \\
\hline $\mathrm{CF}$ & Sul & 3-IV & & Sus & & & & & & $\mathrm{f}$ & \\
\hline $\mathrm{CF}$ & Sul & $3 \mathrm{III}$ & & Sus & & & & & $\mathrm{a}$ & & \\
\hline $\mathrm{CF}$ & Sul & 3-IV & & Sus & & & $\mathrm{d} ?$ & $a / b$ & & & \\
\hline
\end{tabular}

APPENDIX TABLE

Wear stages of the mammal teeth at Lameiras - Chalcolithic. These follow Payne (1987) for sheep and goat, and Grant (1982) for cattle and pigs. "PS" denotes the Payne (1973) mandibular wear stages for more complete mandibles. "P" denotes the presence of a tooth whose wear stage was not determined or determinable. 
APPENDIX B. LAMEIRAS EEN TOOTH WEAR RAW DATA

\begin{tabular}{|c|c|c|c|c|c|c|c|c|c|c|}
\hline Period & UE & ambiente & Tax & $\mathrm{dP}_{4}$ & $\mathbf{P}_{4}$ & $\mathbf{M}_{1}$ & $\mathbf{M}_{2}$ & $\mathbf{M}_{3}$ & $\mathbf{M}_{1 / 2}$ & PS \\
\hline EEN & 75 & $\mathrm{~K} 3 \mathrm{C}$ & Bos & & & & & & e? & \\
\hline EEN & 107 & $\mathrm{~N} 4 \mathrm{C}$ & Bos & & & & & & $\mathrm{h}$ & \\
\hline EEN & 52 & $\mathrm{P} 3 \mathrm{~A}$ & Bos & & & & & & $\mathrm{h} ?$ & \\
\hline EEN & 52 & P3A & Bos & & & & & & $\mathrm{k}$ & \\
\hline EEN & 75 & $\mathrm{~K} 3 \mathrm{C}$ & Bos & & & & & $\mathrm{b}$ & & \\
\hline EEN & 103 & L33 & Bos & & & & & $\mathrm{f}$ & & \\
\hline EEN & 52 & P3A & Bos & $a-c$ & & & & & & \\
\hline EEN & 52 & M4 & Capra? & 14 & & & & & & \\
\hline EEN & 52 & P3A & Capra? & $18 ?$ & & & & & & \\
\hline EEN & 75 & K3D & Ovis/Capra & & & & & & $11 ?$ & \\
\hline EEN & $53 / 52$ & P3A & Ovis/Capra & & & & & & 12 & \\
\hline EEN & 107 & $\mathrm{~N} 4 \mathrm{C} / \mathrm{N} 3 \mathrm{~A}$ & Ovis/Capra & & & & & & 15 & \\
\hline EEN & 103 & L3D & Ovis/Capra & & & & & & 9 & \\
\hline EEN & 75 & L3D & Ovis/Capra & & & & & & 9 & \\
\hline EEN & 52 & $\mathrm{P} 3 \mathrm{~A}$ & Ovis/Capra & & & & & & 9 & \\
\hline EEN & 52 & $\mathrm{P} 3 \mathrm{~A}$ & Ovis/Capra & & & & & & 9 & \\
\hline EEN & 52 & P3B & Ovis/Capra & & & & & & $9 ?$ & \\
\hline EEN & 52 & P3B & Ovis/Capra & & & & & 11 & & \\
\hline EEN & 52 & N4D & Ovis/Capra & & & & 5 & & & \\
\hline EEN & 85 & L4D & Ovis/Capra & & & 11 & $8 / 9$ & & & \\
\hline EEN & 52 & $\mathrm{~N} 4 \mathrm{C}$ & Ovis/Capra & & & 9 & 9 & & & \\
\hline EEN & 107 & $\mathrm{~N} 4 \mathrm{C} / \mathrm{N} 4 \mathrm{D} / \mathrm{N} 3 \mathrm{~A} / \mathrm{N} 3 \mathrm{~B}$ & Ovis/Capra & & 12 & & & & & \\
\hline EEN & 103 & K4D/L4C/L4D & Ovis/Capra & & 9 & & & & & \\
\hline EEN & 75 & $\mathrm{~K} 3 \mathrm{~B}$ & Ovis & 13 & & & & & & \\
\hline EEN & 103 & K4D/L4C/L4D & Ovis? & 13 & & & & & & \\
\hline EEN & 103 & $\mathrm{~K} 4 \mathrm{D} / \mathrm{L} 4 \mathrm{C} / \mathrm{L} 4 \mathrm{D}$ & Sus & & & & & & $\mathrm{a}$ & \\
\hline EEN & 75 & $\mathrm{~J} 3 \mathrm{D}$ & Sus & & & & & & $\mathrm{e}$ & \\
\hline EEN & 103 & L3B & Sus & & & & & $\mathrm{a}$ & & \\
\hline EEN & 52 & $\mathrm{P} 3 \mathrm{~A}$ & Sus & & & & & $\mathrm{c}$ & & \\
\hline EEN & 52 & P4N4 & Sus & $\mathrm{d}$ & & $\mathrm{a}$ & & & & \\
\hline EEN & 52 & N4 & Sus & $\mathrm{d}$ & & $\mathrm{b}$ & & & & \\
\hline
\end{tabular}

APPENDIX TABLE

Wear stages of the mammal teeth at Lameiras - Evolved Early Neolithic. These follow Payne (1987) for sheep and goat, and Grant (1982) for cattle and pigs. 
APPENDIX B. LAMEIRAS EN TOOTH WEAR RAW DATA

\begin{tabular}{|c|c|c|c|c|c|c|c|c|c|c|c|}
\hline Period & Sector & UE & ambiente & Tax & $\mathbf{d P}_{4}$ & $\mathbf{P}_{4}$ & $\mathbf{M}_{1}$ & $\mathbf{M}_{2}$ & $\mathbf{M}_{3}$ & $\mathbf{M}_{1 / 2}$ & PS \\
\hline $\mathrm{EN}$ & M21 & 27 & 8 & Bos & & & & & & $\mathrm{k}$ & \\
\hline $\mathrm{EN}$ & K22 & 41 & & Bos & $1 ?$ & & & & & & \\
\hline $\mathrm{EN}$ & Sul & 53 & M4E & Capra & 13 & & 0 & & & & B \\
\hline $\mathrm{EN}$ & Sul & 113 & N3A/N3C & Ovis/Capra & & & & & & 1 & \\
\hline $\mathrm{EN}$ & Sul & 53 & N3A & Ovis/Capra & & & & & & $10 ?$ & \\
\hline $\mathrm{EN}$ & M21 & 27 & 2 & Ovis/Capra & & & & & & $12-15$ & \\
\hline $\mathrm{EN}$ & L20 & 26 & 4 & Ovis/Capra & & & & & & 5 & \\
\hline $\mathrm{EN}$ & Sul & 53 & N4 & Ovis/Capra & & & & & & 6 & \\
\hline $\mathrm{EN}$ & L20/M20 & 26 & 8 & Ovis/Capra & & & & & & 7 & \\
\hline $\mathrm{EN}$ & $\mathrm{J} 17 / \mathrm{K} 17$ & 39 & 2 & Ovis/Capra & & & & & & 8 & \\
\hline $\mathrm{EN}$ & Sul & 53 & P3 & Ovis/Capra & & & & & & 8 & \\
\hline $\mathrm{EN}$ & Sul & 53 & & Ovis/Capra & & & & & & 9 & \\
\hline $\mathrm{EN}$ & & 33 & E9/E10 & Ovis/Capra & & & & & & 9 & \\
\hline $\mathrm{EN}$ & Sul & 53 & M3A & Ovis/Capra & & & & & & $\mathrm{P}$ & \\
\hline $\mathrm{EN}$ & M21 & 27 & 2 & Ovis/Capra & & & & & 0 & & \\
\hline $\mathrm{EN}$ & M11 & 11 & & Ovis/Capra & & & & & 10 & & \\
\hline $\mathrm{EN}$ & M21 & 27 & 9 & Ovis/Capra & & & & & 2 & & \\
\hline $\mathrm{EN}$ & L20 & 26 & 4 & Ovis/Capra & & & & & $5 / 6$ & & \\
\hline EN & E9 & $7 / 8$ & & Ovis/Capra & & & & 9 & 6 & & $\mathrm{E}$ \\
\hline $\mathrm{EN}$ & Sul & 53 & $\mathrm{P} 4 \mathrm{C}$ & Ovis/Capra & & & 12 & 9 & & & \\
\hline $\mathrm{EN}$ & L20/M20 & 26 & 5 & Ovis/Capra & & & 9 & 9 & & & \\
\hline $\mathrm{EN}$ & E9 & $7 / 8$ & & Ovis/Capra & & 14 & & & & & \\
\hline $\mathrm{EN}$ & Sul & 53 & & Ovis/Capra & & 15 & & & & & \\
\hline $\mathrm{EN}$ & Sul & 53 & P3B & Ovis/Capra & & 9 & & & & & \\
\hline $\mathrm{EN}$ & Sul & 53 & N4D & Ovis/Capra & & 9 & & & & & \\
\hline $\mathrm{EN}$ & L20/M20 & 26 & 5 & Ovis/Capra & & 9 & & & & & \\
\hline $\mathrm{EN}$ & & $35-1$ & E9 & Ovis/Capra & & 9 & & & & & \\
\hline $\mathrm{EN}$ & JK17-18 & 39 & 2 & Ovis/Capra & 23 & & & & & & \\
\hline $\mathrm{EN}$ & E10 & $7 / 8$ & & Ovis & 13 & & & & & & \\
\hline EN & K22 & 41 & & Ovis & 13 & & & & & & \\
\hline $\mathrm{EN}$ & Sul & 100 & $\mathrm{~J} 3 \mathrm{D}$ & Ovis & 13 & & & & & & \\
\hline $\mathrm{EN}$ & Sul & 53 & L4D & Ovis & 14 & & & & & & \\
\hline EN & Sul & 53 & M3B/M4D & Ovis & 14 & & $2 ?$ & & & & \\
\hline $\mathrm{EN}$ & M20 & 26 & 3 & Ovis & 17 & & 9 & 5 & $? \mathrm{U}$ & & ?D \\
\hline $\mathrm{EN}$ & E9 & $10-6$ & & Ovis & 18 & & 9 & 7 & & & \\
\hline $\mathrm{EN}$ & M21 & 27 & 8 & Ovis? & $13 ?$ & & 0 & $\mathrm{U}$ & & & \\
\hline $\mathrm{EN}$ & Sul & 100 & $\mathrm{~J} 2 \mathrm{~A}$ & Ovis? & 14 & & & & & & \\
\hline $\mathrm{EN}$ & E9 & $7 / 8$ & & Sus & & & & & & $\mathrm{a}$ & \\
\hline $\mathrm{EN}$ & E9 & 10 & & Sus & & & & & & a & \\
\hline $\mathrm{EN}$ & M12 & 13 & & Sus & & & & & & $\mathrm{a}$ & \\
\hline $\mathrm{EN}$ & Sul & 53 & L4D & Sus & & & & & & $\mathrm{a}$ & \\
\hline $\mathrm{EN}$ & L20-M20 & 26 & 5 & Sus & & & & & & $\mathrm{a}$ & \\
\hline EN & M8 & 21 & & Sus & & & & & & $\mathrm{c}$ & \\
\hline $\mathrm{EN}$ & M11/12 & 11 & & Sus & & & & & & $\mathrm{d}$ & \\
\hline
\end{tabular}




\begin{tabular}{|l|l|c|l|l|c|c|c|c|c|c|c|}
\hline Period & Sector & UE & ambiente & Tax & $\mathbf{d P}_{4}$ & $\mathbf{P}_{\mathbf{4}}$ & $\mathbf{M}_{\mathbf{1}}$ & $\mathbf{M}_{\mathbf{2}}$ & $\mathbf{M}_{\mathbf{3}}$ & $\mathbf{M}_{\mathbf{1} 2}$ & $\mathbf{P S}$ \\
\hline EN & Sul & 53 & & Sus & & & & & & $\mathrm{e}$ & \\
\hline EN & Sul & 53 & M3B & Sus & & & & & $\mathrm{a}$ & \\
\hline EN & Sul & 53 & N4 & Sus & & & & & $\mathrm{a}$ & & \\
\hline EN & M21 & 27 & 2 & Sus & & & & & U & & \\
\hline EN & J17/K17 & 39 & 1 & Sus & & & & c & & \\
\hline EN & Sul & 53 & N3 & Sus & & a & d? & b? & & & \\
\hline EN & Sul & 53 & & Sus & & b & & & & & \\
\hline EN & M11/12 & 11 & & Sus & & b & & & & & \\
\hline EN & E9 & 10 & & Sus & a & & & & & & \\
\hline EN & M21 & 27 & & Sus & d & & & & & & \\
\hline EN & M20 & 26 & 3 & Sus & e & & & & & & \\
\hline EN & L20-21 & 37 & 2 & Sus & j & & & & & & \\
\hline
\end{tabular}

APPENDIX TABLE

Wear stages of the mammal teeth at Lameiras - Early Neolithic. These follow Payne (1987) for sheep and goat, and Grant (1982) for cattle and pigs. "PS" denotes the Payne (1973) mandibular wear stages for more complete mandibles. "P" denotes the presence of a tooth whose wear stage was not determined or determinable. 
APPENDIX B. LAMEIRAS LN TOOTH WEAR RAW DATA

\begin{tabular}{|c|c|c|c|c|c|c|c|c|c|c|}
\hline Period & UE & ambiente & Tax & $\mathrm{dP}_{4}$ & $\mathbf{P}_{4}$ & $\mathbf{M}_{1}$ & $\mathbf{M}_{2}$ & $\mathbf{M}_{3}$ & $\mathbf{M}_{1 / 2}$ & PS \\
\hline LN & 68 & M4D & Bos & & & & & & $\mathrm{a}$ & \\
\hline $\mathrm{LN}$ & 68 & M3B & Bos & & & & & & $\mathrm{a}$ ? & \\
\hline $\mathrm{LN}$ & 66 & L3D & Bos & & & & & & $\mathrm{f}$ & \\
\hline LN & 68 & M3C & Bos & & & & & & $\mathrm{f}$ & \\
\hline LN & 66 & $\mathrm{~L} 3 \mathrm{C}$ & Bos & & & & & & $\mathrm{g}$ & \\
\hline $\mathrm{LN}$ & 74 & $\mathrm{~J} 4 \mathrm{C}$ & Bos & & & & & & $\mathrm{k}$ & \\
\hline $\mathrm{LN}$ & 68 & M3B & Bos & & & & & & $1 ?$ & \\
\hline $\mathrm{LN}$ & 86 & GLD & Bos & & & & & a & & \\
\hline LN & 68 & $\mathrm{~K} 3 \mathrm{~A}$ & Bos & & & & & $\mathrm{g}$ & & \\
\hline $\mathrm{LN}$ & 78 & $\mathrm{H} 4 \mathrm{D}$ & Bos & & & & & $\mathrm{k}$ & & \\
\hline $\mathrm{LN}$ & 74 & $\mathrm{~J} 4 \mathrm{C}$ & Bos & & & & & $\mathrm{k}$ & & \\
\hline LN & 74 & $\mathrm{~J} 4 \mathrm{C}$ & Bos & & & & 1 & & & \\
\hline LN & 68 & $\mathrm{~K} 3 \mathrm{C}$ & Bos & & a & & & & & \\
\hline $\mathrm{LN}$ & 78 & G3D & Bos & $\mathrm{c} ?$ & & & & & & \\
\hline LN & 66 & K3D & Bos & $\mathrm{e}, \mathrm{f}$ or $\mathrm{g}$ & & & & & & \\
\hline LN & 78 & G3D & Bos & $\mathrm{h}$ & & & & & & \\
\hline LN & 68 & M4D & Bos & $\mathrm{j}$ & & $\mathrm{f}$ & a & $\mathrm{U}$ & & \\
\hline LN & 73 & M3A & Bos & 1 & & & & & & \\
\hline LN & $4 \mathrm{II}$ & M4 & Capra & 13 & & 0 & & & & B \\
\hline $\mathrm{LN}$ & 68 & M3B & Capra & 16 & & & & & & \\
\hline LN & 73 & L3A & Capra & 16 & & 9 & & & & \\
\hline LN & 73 & L3A & Capra & $2-3$ & & & & & & \\
\hline LN & 68 & $\mathrm{M} 3 \mathrm{C}$ & Capra? & 18 & & & & & & \\
\hline LN & 74 & K4D & Capra? & 22 & & & & & & \\
\hline LN & 78 & G3D & Ovis/Capra & & & & & & 0 & \\
\hline LN & 78 & G3D & Ovis/Capra & & & & & & 0 & \\
\hline LN & 68 & L3D & Ovis/Capra & & & & & & 0 & \\
\hline LN & 78 & G3D & Ovis/Capra & & & & & & 1 & \\
\hline LN & UC4 II & N4 & Ovis/Capra & & & & & & 10 & \\
\hline LN & 66 & $\mathrm{~J} 3$ & Ovis/Capra & & & & & & 10 & \\
\hline LN & 74 & $\mathrm{~J} 4 \mathrm{C}$ & Ovis/Capra & & & & & & 12 & \\
\hline LN & 66 & $\mathrm{~L} 4 \mathrm{C}$ & Ovis/Capra & & & & & & 12 & \\
\hline LN & 68 & $\mathrm{~J} 3 / \mathrm{J} 4$ & Ovis/Capra & & & & & & 15 & \\
\hline LN & 86 & $\mathrm{H} 4 \mathrm{C}$ & Ovis/Capra & & & & & & 15 & \\
\hline LN & 68 & $\mathrm{~J} 3 \mathrm{D}$ & Ovis/Capra & & & & & & 2 & \\
\hline $\mathrm{LN}$ & 68 & M3B & Ovis/Capra & & & & & & 2 & \\
\hline LN & 73 & M3A & Ovis/Capra & & & & & & 2 & \\
\hline LN & 68 & M3B & Ovis/Capra & & & & & & 4 & \\
\hline LN & 74 & $\mathrm{~J} 4 \mathrm{C}$ & Ovis/Capra & & & & & & 5 & \\
\hline $\mathrm{LN}$ & 73 & L3B & Ovis/Capra & & & & & & 5 & \\
\hline
\end{tabular}


Continuation

\begin{tabular}{|c|c|c|c|c|c|c|c|c|c|c|}
\hline Period & UE & ambiente & Tax & $\mathrm{dP}_{4}$ & $\mathbf{P}_{4}$ & $M_{1}$ & $\mathrm{M}_{2}$ & $\mathbf{M}_{3}$ & $M_{1 / 2}$ & PS \\
\hline $\mathrm{LN}$ & 74 & LC4 & Ovis/Capra & & & & & & 5 & \\
\hline $\mathrm{LN}$ & 68 & M3A & Ovis/Capra & & & & & & 6 & \\
\hline $\mathrm{LN}$ & 78 & G3D & Ovis/Capra & & & & & & 6 & \\
\hline $\mathrm{LN}$ & 78 & G3D & Ovis/Capra & & & & & & 7 & \\
\hline $\mathrm{LN}$ & 78 & H3B & Ovis/Capra & & & & & & 7 & \\
\hline $\mathrm{LN}$ & 78 & $\mathrm{H} 3 \mathrm{C}$ & Ovis/Capra & & & & & & 7 & \\
\hline $\mathrm{LN}$ & 68 & M3B & Ovis/Capra & & & & & & 7 & \\
\hline $\mathrm{LN}$ & 68 & $\mathrm{~J} 3 \mathrm{D}$ & Ovis/Capra & & & & & & 7 & \\
\hline $\mathrm{LN}$ & 78 & $\mathrm{H} 3 \mathrm{C}$ & Ovis/Capra & & & & & & 7 & \\
\hline $\mathrm{LN}$ & 68 & M4D & Ovis/Capra & & & & & & 7 & \\
\hline $\mathrm{LN}$ & 68 & M3B & Ovis/Capra & & & & & & 7 & \\
\hline $\mathrm{LN}$ & 68 & M3C & Ovis/Capra & & & & & & 8 & \\
\hline $\mathrm{LN}$ & 73 & $\mathrm{~J} 2 \mathrm{~A}$ & Ovis/Capra & & & & & & 8 & \\
\hline $\mathrm{LN}$ & 68 & M3B & Ovis/Capra & & & & & & 8 & \\
\hline $\mathrm{LN}$ & 68 & M3B & Ovis/Capra & & & & & & 8 & \\
\hline $\mathrm{LN}$ & 68 & M3B & Ovis/Capra & & & & & & 8 & \\
\hline $\mathrm{LN}$ & 68 & M3B & Ovis/Capra & & & & & & 8 & \\
\hline $\mathrm{LN}$ & 78 & H3B & Ovis/Capra & & & & & & 8 & \\
\hline $\mathrm{LN}$ & 78 & $\mathrm{H} 3 \mathrm{~B}$ & Ovis/Capra & & & & & & 8 & \\
\hline $\mathrm{LN}$ & 68 & M3C & Ovis/Capra & & & & & & 8 & \\
\hline $\mathrm{LN}$ & 86 & $\mathrm{H} 4 \mathrm{C}$ & Ovis/Capra & & & & & & $8 / 9$ & \\
\hline $\mathrm{LN}$ & 71 & $\mathrm{~L} 4 \mathrm{C}$ & Ovis/Capra & & & & & & 9 & \\
\hline $\mathrm{LN}$ & 68 & $\mathrm{~J} 2 \mathrm{~A}$ & Ovis/Capra & & & & & & 9 & \\
\hline $\mathrm{LN}$ & 71 & L3B & Ovis/Capra & & & & & & 9 & \\
\hline $\mathrm{LN}$ & 71 & L3B & Ovis/Capra & & & & & & 9 & \\
\hline $\mathrm{LN}$ & 71 & K4D & Ovis/Capra & & & & & & 9 & \\
\hline $\mathrm{LN}$ & 66 & $\mathrm{~K} 4 \mathrm{C}$ & Ovis/Capra & & & & & & 9 & \\
\hline $\mathrm{LN}$ & 66 & $\mathrm{~J} 3$ & Ovis/Capra & & & & & & 9 & \\
\hline $\mathrm{LN}$ & 66 & $\mathrm{~J} 3$ & Ovis/Capra & & & & & & 9 & \\
\hline $\mathrm{LN}$ & 68 & L3A & Ovis/Capra & & & & & & 9 & \\
\hline $\mathrm{LN}$ & 68 & M3B & Ovis/Capra & & & & & & 9 & \\
\hline $\mathrm{LN}$ & 68 & M3C & Ovis/Capra & & & & & & 9 & \\
\hline $\mathrm{LN}$ & 73 & L3B & Ovis/Capra & & & & & & 9 & \\
\hline $\mathrm{LN}$ & 68 & M3D & Ovis/Capra & & & & & & 9 & \\
\hline $\mathrm{LN}$ & 68 & M3B & Ovis/Capra & & & & & & 9 & \\
\hline $\mathrm{LN}$ & 68 & M3B & Ovis/Capra & & & & & & 9 & \\
\hline $\mathrm{LN}$ & 74 & L4D & Ovis/Capra & & & & & & 9 & \\
\hline $\mathrm{LN}$ & 71 & L4D & Ovis/Capra & & & & & & 9 & \\
\hline $\mathrm{LN}$ & 66 & L4D & Ovis/Capra & & & & & & 9 & \\
\hline $\mathrm{LN}$ & 74 & $\mathrm{~J} 4 \mathrm{C}$ & Ovis/Capra & & & & & & 9 & \\
\hline
\end{tabular}


Continuation

\begin{tabular}{|c|c|c|c|c|c|c|c|c|c|c|}
\hline Period & UE & ambiente & Tax & $\mathrm{dP}_{4}$ & $\mathbf{P}_{4}$ & $\mathbf{M}_{1}$ & $\mathbf{M}_{2}$ & $\mathbf{M}_{3}$ & $\mathbf{M}_{1 / 2}$ & PS \\
\hline $\mathrm{LN}$ & 71 & L4D & Ovis/Capra & & & & & & 9 & \\
\hline $\mathrm{LN}$ & 74 & L4D & Ovis/Capra & & & & & & 9 & \\
\hline $\mathrm{LN}$ & 78 & $\mathrm{H} 3 \mathrm{~A}$ & Ovis/Capra & & & & & & 9 & \\
\hline $\mathrm{LN}$ & 74 & K4D & Ovis/Capra & & & & & & 9 & \\
\hline $\mathrm{LN}$ & 73 & L3B & Ovis/Capra & & & & & & 9 & \\
\hline $\mathrm{LN}$ & 73 & $\mathrm{~J} 2 \mathrm{~A}$ & Ovis/Capra & & & & & & $9 ?$ & \\
\hline $\mathrm{LN}$ & 74 & K4D & Ovis/Capra & & & & & & $9 ?$ & \\
\hline $\mathrm{LN}$ & 78 & G3D & Ovis/Capra & & & & & & $9 ?$ & \\
\hline $\mathrm{LN}$ & 73 & L3B & Ovis/Capra & & & & & & $\mathrm{P}$ & \\
\hline $\mathrm{LN}$ & 74 & $\mathrm{~L} 4 \mathrm{C}$ & Ovis/Capra & & & & & & $\mathrm{P}$ & \\
\hline $\mathrm{LN}$ & 66 & $\mathrm{~J} 3$ & Ovis/Capra & & & & & 10 & & \\
\hline $\mathrm{LN}$ & 71 & L3A & Ovis/Capra & & & & & 10 & & \\
\hline $\mathrm{LN}$ & 73 & $\mathrm{~K} 3 \mathrm{C}$ & Ovis/Capra & & & & & 10 & & \\
\hline $\mathrm{LN}$ & 73 & L3A & Ovis/Capra & & & & & $10 ?$ & & \\
\hline $\mathrm{LN}$ & $4 \mathrm{III}$ & P4 & Ovis/Capra & & & & & 11 & & \\
\hline LN & 73 & K3B & Ovis/Capra & & & & & 11 & & \\
\hline $\mathrm{LN}$ & 73 & M3D & Ovis/Capra & & & & & 11 & & \\
\hline $\mathrm{LN}$ & 68 & M3B & Ovis/Capra & & & & & 12 & & \\
\hline $\mathrm{LN}$ & 68 & M3C & Ovis/Capra & & & & & 2 & & \\
\hline $\mathrm{LN}$ & 68 & K3D & Ovis/Capra & & & & & 2 & & \\
\hline LN & UC4 II & M4 & Ovis/Capra & & & & & 4 & & \\
\hline $\mathrm{LN}$ & 68 & M3B & Ovis/Capra & & & & & $4 ?$ & & \\
\hline $\mathrm{LN}$ & 74 & L4D & Ovis/Capra & & & & & $6 ?$ & & \\
\hline $\mathrm{LN}$ & 71 & L4D & Ovis/Capra & & & & & 7 & & \\
\hline $\mathrm{LN}$ & 74 & K4D & Ovis/Capra & & & & & 8 & & \\
\hline $\mathrm{LN}$ & 74 & LC4 & Ovis/Capra & & & & & 8 & & \\
\hline $\mathrm{LN}$ & UC4 II & M4 & Ovis/Capra & & & & & 9 & & \\
\hline $\mathrm{LN}$ & 73 & $\mathrm{~J} 2 \mathrm{~A}$ & Ovis/Capra & & & & & 9 & & \\
\hline LN & 68 & M3B & Ovis/Capra & & & & & 9 & & \\
\hline LN & 68 & $\mathrm{~J} 2 \mathrm{~A}$ & Ovis/Capra & & & & 15 & 12 & & I \\
\hline $\mathrm{LN}$ & 73 & L3B & Ovis/Capra & & & & 9 & 9 & & F \\
\hline $\mathrm{LN}$ & 71 & $\mathrm{~K} 4 \mathrm{C}$ & Ovis/Capra & & & 15 & 9 & 11 & & \\
\hline LN & 68 & $\mathrm{~K} 3 \mathrm{C}$ & Ovis/Capra & & & 15 & 9 & 11 & & \\
\hline LN & 82 & G30 & Ovis/Capra & & & 15 & 9 & 11 & & G \\
\hline $\mathrm{LN}$ & 82 & G3B & Ovis/Capra & & & 9 & 4 & 0 & & D \\
\hline $\mathrm{LN}$ & 78 & $\mathrm{H} 3 \mathrm{~A}$ & Ovis/Capra & & & 9 & 6 & & & \\
\hline $\mathrm{LN}$ & 86 & H4D & Ovis/Capra & & & 9 & 6 & & & \\
\hline $\mathrm{LN}$ & 71 & L3B & Ovis/Capra & & & 9 & 7 & & & \\
\hline $\mathrm{LN}$ & 68 & $\mathrm{~J} 2 \mathrm{~A}$ & Ovis/Capra & & & 9 & 7 & 1 & & E \\
\hline $\mathrm{LN}$ & 68 & $\mathrm{M} 4 \mathrm{C}$ & Ovis/Capra & & & 9 & 7 & $2 ?$ & & E? \\
\hline
\end{tabular}


Continuation

\begin{tabular}{|c|c|c|c|c|c|c|c|c|c|c|}
\hline Period & UE & ambiente & Tax & $\mathrm{dP}_{4}$ & $\mathbf{P}_{4}$ & $\mathbf{M}_{1}$ & $\mathbf{M}_{2}$ & $\mathbf{M}_{3}$ & $M_{1 / 2}$ & PS \\
\hline $\mathrm{LN}$ & 74 & L4D & Ovis/Capra & & & 9 & 9 & & & \\
\hline $\mathrm{LN}$ & 74 & L4D & Ovis/Capra & & & $9 ?$ & 9 & & & \\
\hline LN & 86 & $\mathrm{H} 4 \mathrm{D}$ & Ovis/Capra & & 0 & & & & & \\
\hline LN & 73 & K3B & Ovis/Capra & & 0 & 9 & 8 & 0 & & $\mathrm{D}$ \\
\hline LN & 66 & $\mathrm{~J} 3$ & Ovis/Capra & & 11 & 9 & 9 & & & \\
\hline $\mathrm{LN}$ & 68 & M3A & Ovis/Capra & & 12 & & & & & \\
\hline LN & 82 & G30 & Ovis/Capra & & 12 & & & & & \\
\hline $\mathrm{LN}$ & 66 & L4D & Ovis/Capra & & 12 & & & & & \\
\hline $\mathrm{LN}$ & 68 & M3A & Ovis/Capra & & 12 & & & 8 & & $\mathrm{~F}$ \\
\hline $\mathrm{LN}$ & 68 & J3D & Ovis/Capra & & 12 & 12 & 9 & 7 & & $\mathrm{~F}$ \\
\hline $\mathrm{LN}$ & 71 & L4C & Ovis/Capra & & 12 & 15 & 9 & $11 ?$ & & $\mathrm{G}$ \\
\hline $\mathrm{LN}$ & 74 & L4D & Ovis/Capra & & 12 & 9 & 9 & 9 & & $\mathrm{~F}$ \\
\hline $\mathrm{LN}$ & 74 & K4D & Ovis/Capra & & 14 & 11 & 9 & 11 & & G \\
\hline $\mathrm{LN}$ & $4 \mathrm{II}$ & M4 & Ovis/Capra & & 14 & 15 & 11 & 11 & & $\mathrm{H}$ \\
\hline $\mathrm{LN}$ & 68 & M3B & Ovis/Capra & & 15 & 15 & 12 & 11 & & $\mathrm{H}$ \\
\hline $\mathrm{LN}$ & 74 & $\mathrm{~J} 4 \mathrm{D}$ & Ovis/Capra & & 3 & 9 & 8 & 2 & & $\mathrm{E}$ \\
\hline $\mathrm{LN}$ & 68 & M4D & Ovis/Capra & & 5 & & & & & \\
\hline $\mathrm{LN}$ & 68 & $\mathrm{~J} 2 \mathrm{~A}$ & Ovis/Capra & & 5 & 9 & 7 & $5 ?$ & & $\mathrm{E} / \mathrm{F}$ \\
\hline $\mathrm{LN}$ & 68 & $\mathrm{M} 3 \mathrm{C}$ & Ovis/Capra & & 8 & & & & & \\
\hline $\mathrm{LN}$ & 68 & $\mathrm{~K} 3 \mathrm{D}$ & Ovis/Capra & & 8 & & & & & \\
\hline $\mathrm{LN}$ & 74 & $\mathrm{LC} 4$ & Ovis/Capra & & 8 & $\mathrm{P}$ & 9 & 3 & & $\mathrm{E}$ \\
\hline $\mathrm{LN}$ & 74 & $\mathrm{~L} 4 \mathrm{C}$ & Ovis/Capra & & 9 & & & & & \\
\hline $\mathrm{LN}$ & 71 & L4D & Ovis/Capra & & 9 & & & & & \\
\hline $\mathrm{LN}$ & 71 & $\mathrm{~L} 4 \mathrm{C}$ & Ovis/Capra & & 9 & 9 & 9 & 6 & & $\mathrm{E}$ \\
\hline $\mathrm{LN}$ & 73 & L3A & Ovis/Capra & & $9 ?$ & 11 & 9 & 10 & & $\mathrm{~F}$ \\
\hline $\mathrm{LN}$ & 78 & $\mathrm{H} 3 \mathrm{~A}$ & Ovis/Capra & 7,8 or 9 & & & & & & \\
\hline $\mathrm{LN}$ & 68 & L4D & Ovis/Capra & $\mathrm{P}$ & & & & & & \\
\hline $\mathrm{LN}$ & 73 & L3B & Ovis & $12-14 ?$ & & & & & & \\
\hline $\mathrm{LN}$ & 68 & M3A & Ovis & 13 & & 0 & & & & B \\
\hline $\mathrm{LN}$ & UC4 II & M4 & Ovis & $13 ?$ & & 7 & & & & \\
\hline $\mathrm{LN}$ & 68 & $\mathrm{~J} 3 \mathrm{D}$ & Ovis & 14 & & & & & & \\
\hline $\mathrm{LN}$ & 78 & $\mathrm{H} 3 \mathrm{C}$ & Ovis & 14 & & & & & & \\
\hline $\mathrm{LN}$ & 74 & LC4 & Ovis & 14 & & $5 ?$ & 0 & & & $\mathrm{C}$ \\
\hline $\mathrm{LN}$ & 68 & $\mathrm{~K} 3 \mathrm{C}$ & Ovis & 14 & & 7 & $\mathrm{U}$ & & & $\mathrm{C}$ \\
\hline $\mathrm{LN}$ & 78 & G3D & Ovis & 16 & & 7 & 0 & & & $\mathrm{C}$ \\
\hline $\mathrm{LN}$ & 73 & $\mathrm{~J} 2 \mathrm{~A}$ & Ovis & 18 & & 9 & 5 & & & \\
\hline $\mathrm{LN}$ & 78 & $\mathrm{H} 3 \mathrm{C}$ & Ovis & $\mathrm{P}$ & & & & & & \\
\hline $\mathrm{LN}$ & 74 & $\mathrm{~J} 4 \mathrm{C}$ & Ovis? & $12-14 ?$ & & & & & & \\
\hline $\mathrm{LN}$ & 68 & M3B & Ovis? & $12-14 ?$ & & & & & & \\
\hline $\mathrm{LN}$ & 4 III & P3 & Ovis? & 14 & & & & & & \\
\hline
\end{tabular}




\section{Continuation}

\begin{tabular}{|c|c|c|c|c|c|c|c|c|c|c|}
\hline Period & UE & ambiente & Tax & $\mathrm{dP}_{4}$ & $\mathbf{P}_{4}$ & $\mathbf{M}_{1}$ & $\mathbf{M}_{2}$ & $\mathbf{M}_{3}$ & $\mathbf{M}_{1 / 2}$ & PS \\
\hline LN & 74 & $\mathrm{~J} 4 \mathrm{C}$ & Ovis? & 14 & & & & & & \\
\hline LN & 68 & K3B & Ovis? & 19 & & & & & & \\
\hline LN & 68 & M3B & Ovis? & 21 & & 9 & 7 & $\mathrm{U}$ & & D \\
\hline LN & 66 & $\mathrm{~L} 4 \mathrm{C}$ & Sus & & & & & & $\mathrm{a}$ & \\
\hline LN & 71 & K4D & Sus & & & & & & $\mathrm{b}$ & \\
\hline LN & 73 & L3A & Sus & & & & & & $\mathrm{b} / \mathrm{c}$ & \\
\hline LN & 68 & K3D & Sus & & & & & & $\mathrm{c}$ & \\
\hline LN & 71 & L3B & Sus & & & & & & d & \\
\hline LN & 68 & $\mathrm{M} 4 \mathrm{C}$ & Sus & & & & & & $\mathrm{f}$ & \\
\hline LN & 68 & M4D & Sus & & & & & $\mathrm{a}$ ? & & \\
\hline $\mathrm{LN}$ & 73 & L3B & Sus & & & & & $a-b$ & & \\
\hline LN & 73 & $\mathrm{~K} 3 \mathrm{C}$ & Sus & & & & & $\mathrm{b}$ & & \\
\hline LN & 73 & L3C & Sus & & & & & b & & \\
\hline LN & 68 & $\mathrm{~J} 2 \mathrm{~A}$ & Sus & & & & & $\mathrm{b}$ & & \\
\hline LN & 78 & $\mathrm{H} 3 \mathrm{~A}$ & Sus & & & & & $\mathrm{d}$ & & \\
\hline LN & $4 \mathrm{III}$ & M4 & Sus & & & $\mathrm{c}$ & a & & & \\
\hline LN & 78 & G3D & Sus & & & $\mathrm{f}$ & e? & & & \\
\hline LN & 68 & $\mathrm{~J} 3 / \mathrm{J} 4$ & Sus & & & $\mathrm{j}$ & d & $\mathrm{b}$ & & \\
\hline LN & 73 & K3D & Sus & & $\mathrm{a}$ & & & & & \\
\hline LN & 68 & $\mathrm{~K} 3 \mathrm{~A}$ & Sus & & $\mathrm{b}$ & $\mathrm{f}$ & e & $\mathrm{b}$ & & \\
\hline LN & 73 & $\mathrm{~K} 3 \mathrm{C}$ & Sus & & $\mathrm{c}$ & & & & & \\
\hline LN & 73 & L3A & Sus & a & & & & & & \\
\hline LN & $4 \mathrm{III}$ & N4 & Sus & a & & & & & & \\
\hline LN & 74 & K4D & Sus & $\mathrm{b}$ & & & & & & \\
\hline LN & 73 & M3A & Sus & b & & a & & & & \\
\hline LN & 73 & L3B & Sus & $\mathrm{d}$ & & & & & & \\
\hline LN & 74 & K4D & Sus & $\mathrm{f}$ & & & & & & \\
\hline
\end{tabular}

APPENDIX TABLE

Wear stages of the mammal teeth at Lameiras - Late Neolithic. These follow Payne (1987) for sheep and goat, and Grant (1982) for cattle and pigs. "PS" denotes the Payne (1973) mandibular wear stages for more complete mandibles. "P" denotes the presence of a tooth whose wear stage was not determined or determinable. 
APPENDIX C. MEASUREMENTS OF FISH TEEH AND BONES

\begin{tabular}{|c|c|c|c|c|c|c|c|c|c|c|c|}
\hline SECTOR & UE & NISP & Bone & Side & Taxon & M1 & M2 & M3 & M4 & $\mathbf{A H}$ & Notes \\
\hline M21 & $27-26$ & 1 & $\mathrm{~V}(1-40)$ & - & cf. Mustelus mustelus & 7,36 & 7,69 & 6,93 & - & - & Pierced \\
\hline $\mathrm{L} 22$ & 47 & 1 & $\mathrm{~V}(15-40)$ & - & cf. Mustelus mustelus & 6,75 & 7,12 & 6 & - & - & - \\
\hline M21 & $27-2$ & 1 & $\mathrm{~V}$ & - & cf. Triakidae & 14,56 & 15,63 & 11,08 & - & - & Pierced \\
\hline $\mathrm{JK} / 17-18$ & $39-8$ & 1 & $\mathrm{~V}$ & - & cf. Triakidae & 12,29 & 13,12 & 8,65 & - & - & Pierced \\
\hline M20 & $26-3$ & 1 & $\mathrm{~V}$ & - & cf. Triakidae & - & - & - & - & - & - \\
\hline L20-L21 & $37-2$ & 1 & $\mathrm{~V}$ & & cf. Triakidae & - & - & - & - & - & - \\
\hline L20-L21 & $37-1$ & 1 & $\mathrm{~V}$ & - & $\begin{array}{l}\text { cf. Triakidae/ cf. Sphyrnidae/ } \\
\text { cf. Carcharhinidae }\end{array}$ & - & - & 6,8 & - & - & - \\
\hline $\begin{array}{l}\text { Sul_N3A/ } \\
\text { N3C }\end{array}$ & 108 & 1 & $\mathrm{~V}$ & - & $\begin{array}{l}\text { cf. Triakidae/ cf. Sphyrnidae/ } \\
\text { cf. Carcharhinidae }\end{array}$ & 11,82 & 12,81 & 7,98 & - & - & - \\
\hline M21 & $27-2$ & 1 & $\mathrm{~V}$ & - & $\begin{array}{l}\text { cf. Triakidae/ cf. Sphyrnidae/ } \\
\text { cf. Carcharhinidae }\end{array}$ & 9,09 & 8,01 & 4,41 & - & - & Pierced \\
\hline L20 & $26-4$ & 1 & $\mathrm{~V}$ & - & Elasmobranchii & 5 & - & - & - & - & Pierced \\
\hline M21 & $27-2$ & 1 & $\mathrm{~V}$ & - & Elasmobranchii & 3,46 & 3,42 & - & - & - & Pierced \\
\hline M21 & $27-8$ & 1 & $\mathrm{~V}$ & - & Elasmobranchii & 5,83 & 6,56 & 4,25 & - & - & Pierced \\
\hline M18 & 31 & 1 & $\mathrm{~V}(1)$ & - & Sardina pilchardus & - & 2,4 & - & - & - & - \\
\hline M18 & 31 & 5 & $\mathrm{Vpc}$ & - & Sardina pilchardus & - & - & - & - & - & - \\
\hline M18 & 31 & 3 & $\mathrm{Vc}$ & - & cf. Sardina pilchardus & - & - & - & - & - & - \\
\hline $\mathrm{J} 17-\mathrm{K} 17$ & $39-1-2$ & 1 & $\mathrm{Vpc}$ & - & cf. Sardina pilchardus & - & - & - & - & - & - \\
\hline $\mathrm{J} 17-\mathrm{K} 17$ & $39-1-2$ & 1 & $\mathrm{Vpc}$ & - & cf. Sardina pilchardus & - & - & - & - & - & - \\
\hline J-K 17 & $39-2$ & 1 & $\mathrm{~V}$ & - & cf. Sardina pilchardus & - & - & - & - & - & - \\
\hline E9 & 10 & 1 & $\mathrm{Vc}(12-13)$ & - & cf. Pomatomus saltatrix & 13,12 & 15,114 & 17,41 & - & - & - \\
\hline J-K 17_18 & $39 \_3$ & 1 & $\mathrm{Vpc}(6)$ & - & $\begin{array}{l}\text { cf. Sciaenidae Argyrosomus } \\
\text { regius }\end{array}$ & - & - & - & - & - & - \\
\hline J-K 17 & $39 \_1$ & 1 & $\mathrm{Vpc}$ & - & cf. Sciaenidae & - & - & - & - & - & - \\
\hline $\mathrm{J} 17 / \mathrm{K} 17$ & 39_1 & 1 & DT & $\mathrm{R}$ & cf. Dentex gibbosus & - & - & - & - & 16,39 & - \\
\hline L20-L21 & $37 \_2$ & 1 & $\mathrm{Vpc}(2-3)$ & - & cf. Dentex gibbosus & 15,19 & 15,47 & 12,19 & - & - & - \\
\hline E9/E10 & 33 & 1 & DT & $\mathrm{R}$ & Pagrus sp. & - & - & - & - & 10,51 & - \\
\hline J-K 17_18 & $39-7$ & 1 & $\mathrm{Vpc}$ & - & cf. Pagrus sp. & 8,85 & 8,31 & 8,76 & - & - & - \\
\hline $\mathrm{J} 17-\mathrm{K} 17$ & $39-1$ & 1 & $\mathrm{~V}$ & - & cf. Sarpa salpa & 8,22 & - & 10,72 & - & - & - \\
\hline J-K 17_18 & $39-2$ & 1 & $\mathrm{Vc}$ & - & cf. Sarpa salpa & 3,73 & 3,82 & 5,92 & - & - & - \\
\hline L20-M20 & $27-7$ & 1 & $\mathrm{Vc}$ & - & cf. Sarpa salpa & 3,94 & 3,76 & 6,98 & - & - & - \\
\hline E10 & $07-8$ & 1 & $\mathrm{Vpc}(2)$ & - & Sparus aurata & 11,87 & 12,27 & 9,05 & - & - & - \\
\hline $\mathrm{JK} / 17-18$ & $39-2$ & 1 & $\mathrm{Vpc}(2-3)$ & - & cf. Spondyliosoma cantharus & 9,62 & 9,88 & 7,3 & - & - & - \\
\hline L20/M20 & $26-5$ & 1 & $\mathrm{~d}$ & - & Sparidae & - & - & - & - & - & - \\
\hline J-K 17_18 & $39-2$ & 1 & $\mathrm{Vpc}$ & - & Sparidae & 7,46 & 8,54 & 10,61 & - & - & - \\
\hline M21 & $27-7$ & 1 & $\mathrm{~d}$ & - & Sparidae & - & - & - & - & - & - \\
\hline J-K 17_18 & $39-2$ & 1 & Q & - & Sparidae & - & - & - & - & - & - \\
\hline J-K 17_18 & $39-2$ & 1 & $\mathrm{Vc}$ & - & Sparidae & 8,23 & 8,26 & 11,03 & - & - & - \\
\hline J-K 17_18 & $39-5$ & 1 & d & - & cf. Sparidae & - & - & - & - & - & - \\
\hline J-K 17-18 & $39-7$ & 1 & $\mathrm{~V}$ & - & cf. Sparidae & - & - & - & - & - & - \\
\hline $\mathrm{N} 3 \mathrm{C}$ & 113 & 1 & $\mathrm{~d}$ & - & cf. Sparidae & - & - & - & - & - & - \\
\hline M18 & $31-1$ & 1 & $\mathrm{~V}$ & - & cf. Sparidae & - & - & - & - & - & - \\
\hline
\end{tabular}


Continuation

\begin{tabular}{|c|c|c|c|c|c|c|c|c|c|c|c|}
\hline SECTOR & $\mathbf{U E}$ & NISP & Bone & Side & Taxon & M1 & M2 & M3 & M4 & AH & Notes \\
\hline L20-21 & $\begin{array}{l}37- \\
\text { LIMPEZA } \\
\text { FOSSA } 38\end{array}$ & 1 & OP & $\mathrm{L}$ & cf. Sparidae & - & - & - & - & - & - \\
\hline E9 & $10-6$ & 1 & $\mathrm{Vpc}(9-11)$ & - & Liza sp. & - & - & 9,69 & - & - & - \\
\hline $\mathrm{JK} / 17-18$ & $39-2$ & 1 & V & - & Teleostei & - & - & - & - & - & - \\
\hline JK17-18 & $39-4$ & 1 & $\mathrm{~V}$ & - & Teleostei & - & - & $((8,85))$ & - & - & - \\
\hline J-K 17-18 & $39-7$ & 1 & $\mathrm{Vpc}$ & - & Teleostei & - & - & 5,9 & - & - & - \\
\hline J-K 17-18 & $39-2$ & 1 & $\mathrm{Vc}$ & - & Teleostei & - & - & - & - & - & - \\
\hline E9 & 10 & 1 & V & - & Teleostei & - & - & - & - & - & - \\
\hline L20-M20 & $26 \_5$ & 1 & $\mathrm{~V}$ & - & Teleostei & - & - & - & - & - & - \\
\hline Sul-M3D & 53 & 1 & $\mathrm{Vpc}$ & - & Teleostei & - & - & - & - & - & - \\
\hline J-K 17-18 & $39-2$ & 1 & $\mathrm{CR}$ & - & Teleostei & - & - & - & - & - & - \\
\hline J-K 17-18 & $39-2$ & 1 & Q & - & Teleostei & - & - & - & - & - & - \\
\hline E9 & 10 & 1 & $\mathrm{Q}$ & - & Teleostei & - & - & - & - & - & - \\
\hline J-K 17-18 & $39-3$ & 1 & PTP & $\mathrm{R}$ & Teleostei & - & - & - & - & - & - \\
\hline J-K 17-18 & $39-2$ & 1 & $\begin{array}{l}\text { POP frag- } \\
\text { ment? }\end{array}$ & $\mathrm{R}$ ? & Teleostei & - & - & - & - & - & - \\
\hline J-K 17-18 & $39-2$ & 1 & $\mathrm{Vpc}$ & - & Teleostei & 3,96 & 3,34 & 4,35 & - & - & - \\
\hline M20 & $26-3$ & 1 & $\begin{array}{l}\text { Dorsal fin } \\
\text { spine }\end{array}$ & - & Teleostei & - & - & - & - & - & - \\
\hline E9-10 & 33 & 1 & $\begin{array}{l}\text { Dorsal fin } \\
\text { spine }\end{array}$ & - & Teleostei & - & - & - & - & - & - \\
\hline E9 & $10-6$ & 1 & Undetermined & - & Undetermined & - & - & - & - & - & - \\
\hline J-K $17-18$ & $39-2$ & 1 & Undetermined & - & Undetermined & - & - & - & - & - & - \\
\hline J-K 17 & $39-2$ & 2 & Undetermined & - & Undetermined & - & - & - & - & - & - \\
\hline M21 & $27-5$ & 1 & Undetermined & - & Undetermined & - & - & - & - & - & - \\
\hline Sul-L4A & 85 & 1 & $\mathrm{~V}$ & - & Chondrichthyes & 5,76 & 5,98 & 4,02 & - & - & - \\
\hline Sul-L4D & 106 & 1 & Vpc2 & - & cf. Sparus aurata & 7,63 & 7,11 & 5,18 & - & - & - \\
\hline Sul-L4A & 85 & 1 & Vpc2-5 & - & Scomber scombrus & 5,69 & 6,33 & 9,31 & - & - & - \\
\hline K3D & 73 & 1 & d & - & $\begin{array}{l}\text { cf. Lamnidae } \\
\text { (Isurus oxyrinchus ) }\end{array}$ & 32,18 & 14,42 & - & - & - & - \\
\hline Sul-K4D & 71 & 1 & d & - & Sparus aurata & 17,06 & 4,44 & - & - & - & - \\
\hline Sul-L3B & 73 & 1 & $\mathrm{~d}$ & - & cf. Sparidae & - & - & - & - & - & - \\
\hline Sul-L3B & 73 & 1 & $\mathrm{~d}$ & - & ND & - & - & - & - & - & - \\
\hline Sul_M3A & 119 & 1 & V & - & $\begin{array}{l}\text { Chondrichthyes } \\
\text { (cf. Triakidae) }\end{array}$ & 16,01 & 15,62 & 13,54 & - & - & - \\
\hline Sul_P3A-B & $\begin{array}{l}\text { Limpeza } \\
\text { corte sul } \\
{[54]}\end{array}$ & 1 & $\mathrm{~V}$ & - & Teleostei & - & - & - & - & - & - \\
\hline & & & & & & & & & & & \\
\hline
\end{tabular}




\section{Continuation}

\begin{tabular}{|l|l|c|l|c|l|c|c|c|c|c|c|}
\hline SECTOR & UE & NISP & Bone & Side & Taxon & M1 & M2 & M3 & M4 & AH & Notes \\
\hline E9 & 7 & 1 & O_sagitta & - & cf. Merlucciidae & - & - & - & - & - & - \\
\hline E10 & 7 & 1 & Vc19 & - & Trachurus trachurus & 6,05 & 7,62 & 11,34 & - & - & - \\
\hline 10 & 7 & 1 & PLT & L & cf. Sparidae & - & - & - & - & - & - \\
\hline E10 & 7 & 1 & PM & - & NID & - & - & - & - & - & - \\
\hline
\end{tabular}

APPENDIX TABLE

A list of the Lameiras fish remains with their measurements. Key Bone: DT - Dentary; d - individual teeth; O - Otolith; OP - Operculum; PLT - Palatine; PM - Premaxilar; PTP - Postemporal; Q - Quadrate; V - vertebra; Vpc - Precaudal vertebra; Vc - Caudal vertebra (numbers indicate the position of the vertebra in the vertebral column counting from the first vertebra onwards); Side: L - Left; R - Right; Measurements in millimetres (following Morales \& Rosenlund, 1979): AH - Anterior height of the dentary; M1 - Greatest dorso-ventral height of the centrum (cranial view); M2 - Greatest medio-lateral breadth of the centrum (cranial view); M3 - Greatest cranio-caudal length of the centrum (lateral view). 
